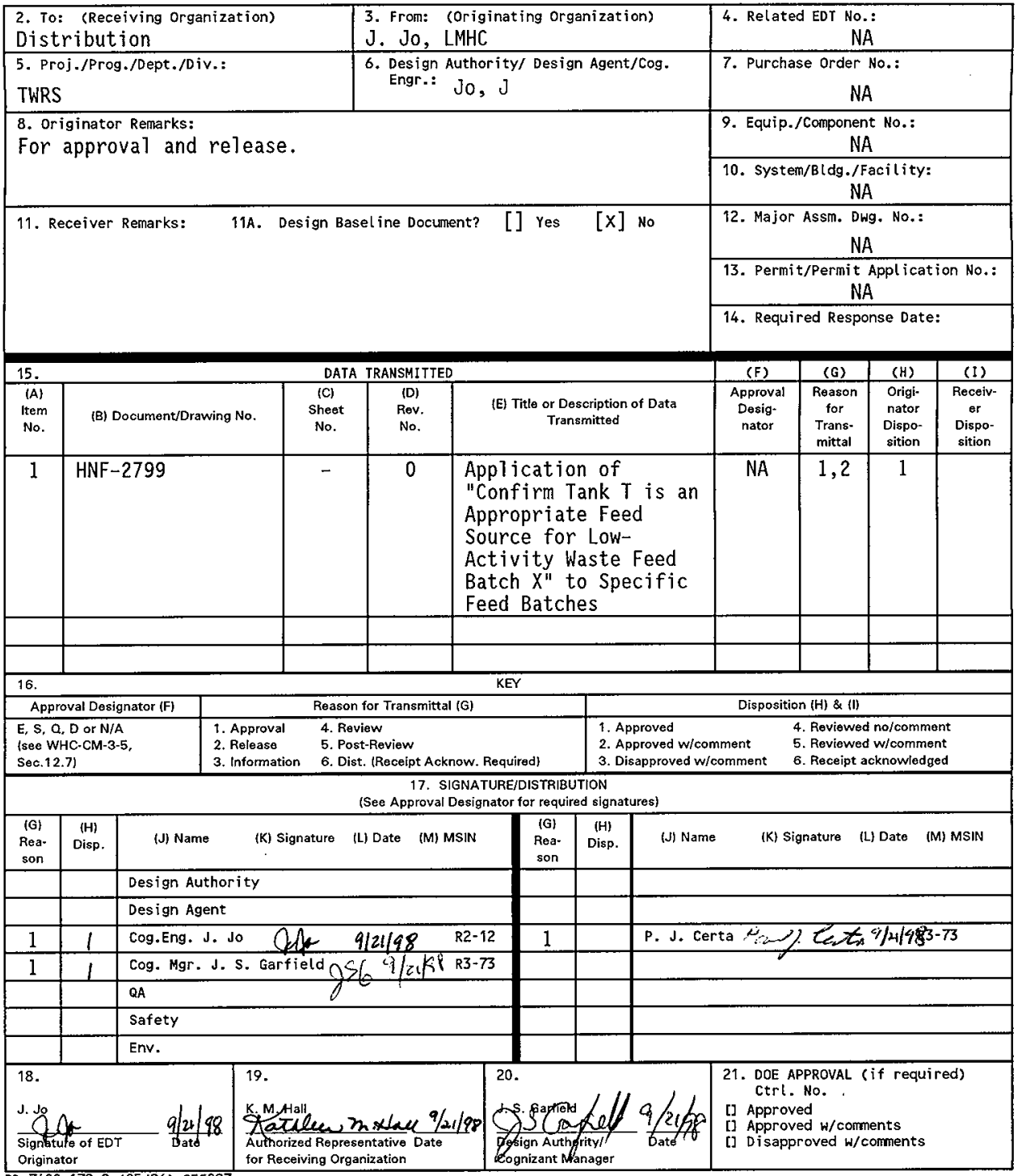




\section{Application of "Confirm Tank $\mathrm{T}$ is an Appropriate Feed Source for Low-Activity Waste Feed Batch $X "$ to Specific Feed Batches}

J. Jo

Lockheed Martin Hanford Corporation, Richland, WA 99352

U.S. Department of Energy Contract DE-AC06-96RL13200

EDT/ECN: 624562

UC: 721

Org Code: $8 \mathrm{C} 451$

Charge Code: D2D28

B\&R Code: EW3130010

Tota1 Pages: 221

Key Words: Data quality objectives, DQO, PSDQ0, TWRS

Abstract: This document addresses the characterization needs of tanks as set forth in the "Confirm Tank $T$ is an Appropriate Feed Source for Low-Activity Waste Feed Batch X" Data Quality Objective (Certa and Jo 1998).

TRADEMARK DISCLAIMER. Reference herein to any specific commercial product, process, or service by trade name, trademark, manufacturer, or otherwise, does not necessarily constitute or imply its endorsement, recommendation, or favoring by the United States Government or any agency thereof or its contractors or subcontractors.

Printed in the United States of America. To obtain copies of this document, contact: Document Control Services, P.O. Box 950, Mailstop H6-08, Richland WA 99352, Phone (509) 372-2420; Fax (509) 376-4989.
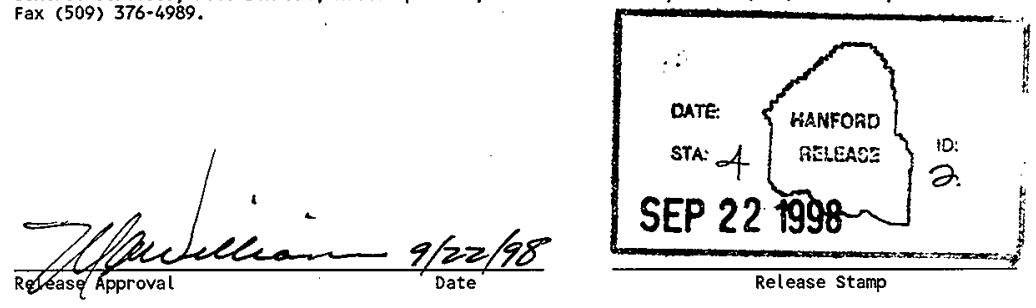


\title{
APPLICATION OF "CONFIRM TANK T IS AN APPROPRIATE FEED SOURCE FOR LOW-ACTIVITY WASTE FEED BATCH X" TO SPECIFIC FEED BATCHES
}

September 1998

\author{
J. Jo \\ Lockheed Martin Hanford Corporation \\ Richland, Washington
}

Prepared for

U.S. Department of Energy

Richland, Washington 
HNF-2799

Revision 0

This page intentionally left blank. 


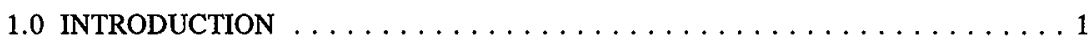

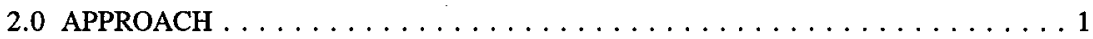

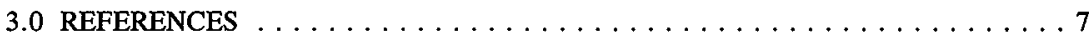

ADDENDUM 1 - TANK 241-AN-105/BATCH $1 \ldots \ldots \ldots \ldots$ Addendum 1 -1

ADDENDUM 2 - TANK 241 -AN-104/BATCH $2 \ldots \ldots \ldots$ Addendum 2 -1

ADDENDUM 3 - TANK 241-AW-101/BATCH $3 \ldots \ldots \ldots \ldots$ Addendum 3-1

ADDENDUM 4 - TANK 241-AN-103/BATCH $4 \ldots \ldots \ldots \ldots$ Addendum 4-1

ADDENDUM 5 - TANK 241-AZ-101/102/BATCH $5 \ldots \ldots \ldots$ Addendum 5-1

ADDENDUM 6 - TANK 241-AN-107/BATCHES 6 AND $7 \ldots \ldots$. . Addendum 6-1

ADDENDUM 7 - TANK 241-AN-102/BATCH $8 \ldots \ldots \ldots$ Addendum $7-1$

ADDENDUM 8 - TANK $241-$ SY-101/BATCH $10 \ldots \ldots \ldots \ldots$ Addendum 8 -1

ADDENDUM 9 - TANK 241-SY-103/BATCH $11 \ldots \ldots \ldots \ldots$ Addendum 9 -1

\section{LIST OF FIGURES}

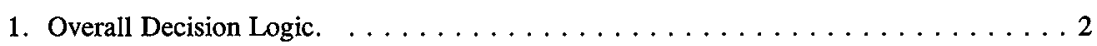

\section{LIST OF TABLES}

1. Low-Activity Waste Feed Liquid Phase Chemical Composition. . . . . . . . . . 4

2. Low-Activity Waste Feed Liquid Phase Radionuclide Content. . . . . . . . . 5

3. Applicable Waste Composition Limits from OSD-T-151-00007 (PHMC 1997). . . . . 6 
HNF-2799

Revision 0

\section{LIST OF TERMS}

DQO Data Quality Objective

ESP $^{1}$

Environmental Simulation Program

LAW

Low-activity waste

PSDQO

Problem-Specific Data Quality Objectives

TSAP

Tank Sampling and Analysis Plan

TWRS

Tank Waste Remediation System

${ }^{1}$ ESP is a trademark of OLI Systems, Inc.

iv 
HNF-2799

Revision 0

\section{APPLICATION OF "CONFIRM TANK T IS AN APPROPRIATE FEED SOURCE FOR LOW-ACTIVITY WASTE FEED BATCH $X^{n}$ TO SPECIFIC FEED BATCHES}

\subsection{INTRODUCTION}

This document addresses the characterization needs of tanks as set forth in the "Confirm Tank $T$ is an Appropriate Feed Source for Low-Activity Waste Feed Batch X" Data Quality Objective (DQO) (Certa and Jo 1998).

The primary purpose of this document is to collect existing data and identify the data needed to determine whether or not the feed source(s) are appropriate for a specific batch before transfer is made to the feed staging tanks. To answer these questions, the existing tank data must be collected and a detailed review performed.

If the existing data are insufficient to complete a full comparison, additional data must be obtained from the feed source(s). Additional information requirements need to be identified and formally documented, then the source tank waste must be sampled or resampled and analyzed. Once the additional data are obtained, the data shall be incorporated into the existing database for the source tank and a reevaluation of the data against the DQO must be made.

\subsection{APPROACH}

The Tank Waste Retrieval Division has determined that a strategic and cost-effective way to identify the data needed for low-activity waste (LAW) feed delivery is to define those data needs on a batch-by-batch basis using the DQO process. The overall decision logic is shown schematically in Figure 1.

The first step in identifying the data need is for the Tank Waste Retrieval Division to translate its operating scenario into a series of process steps (essentially a process flowsheet) that clearly defines the waste to which each element of the decision rule applies. Alternatives to the baseline operating scenario may also be addressed.

The second step is to apply the decision rule to each group of operating scenario activities that constitute a source of waste feed going to the waste feed staging tanks. 
HNF-2799

Revision 0

Figure 1. Overall Decision Logic.

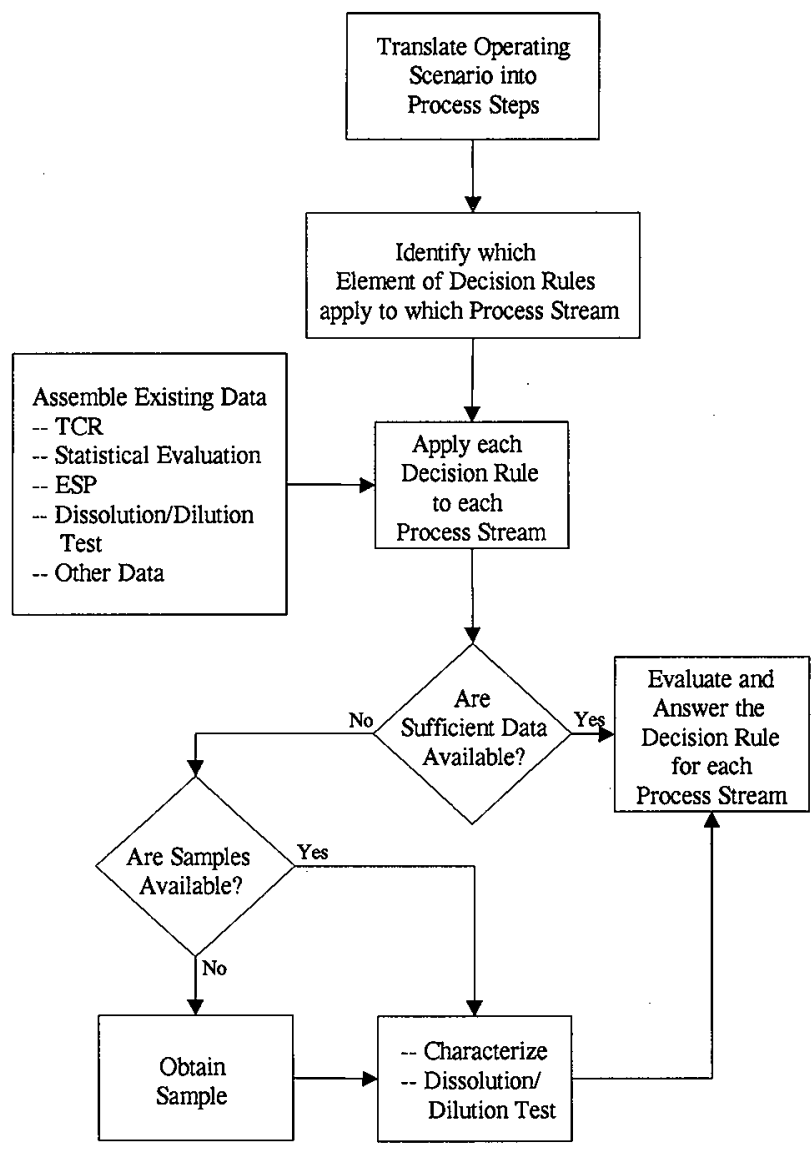

ESP $^{1}=$ Environmental Simulation Program

TCR $=$ Tank Characterization Report

${ }^{\mathrm{l}}$ ESP is a trademark of OLI Systems, Inc. 
HNF-2799

Revision 0

The third step is to determine if the data needed to address each element can be supplied by or approximated with existing (Best-Basis Inventory) or new characterization data on the waste, statistical evaluations, mathematical or process models such as Environmental Simulation Program $\left(\mathrm{ESP}^{1}\right)$, or by process testing on existing or new samples including dissolution/dilution testing.

If the existing data are insufficient to complete a full evaluation, additional data must be obtained from Tank $\mathrm{T}$. The missing information needs to be identified and formally documented in this document. Unless sufficient archived samples can be found, Tank $T$ waste must be sampled and analyzed. Once these data are obtained, they shall be compiled into the existing database for Tank $\mathrm{T}$ and a reevaluation of the data must be made and compared to Tables 1, 2, and 3.

${ }^{1}$ ESP is a trademark of OLI Systems, Inc. 
HNF-2799

Revision 0

Table 1. Low-Activity Waste Feed Liquid Phase Chemical Composition.

\begin{tabular}{|c|c|c|c|}
\hline \multirow{2}{*}{$\begin{array}{l}\text { Chemical } \\
\text { Analyte }\end{array}$} & \multicolumn{3}{|c|}{ Maximum ratio, analyte (mole) to sodium (mole) } \\
\hline & Envelope A & Envelope B & Envelope C \\
\hline $\mathrm{Al}$ & $1.9 \mathrm{E}-01$ & $1.9 \mathrm{E}-01$ & $1.9 \mathrm{E}-01$ \\
\hline $\mathrm{Ba}$ & $1.0 \mathrm{E}-04$ & $1.0 \mathrm{E}-04$ & $1.0 \mathrm{E}-04$ \\
\hline $\mathrm{Ca}$ & $4.0 \mathrm{E}-02$ & $4.0 \mathrm{E}-02$ & $4.0 \mathrm{E}-02$ \\
\hline $\mathrm{Cd}$ & $4.0 \mathrm{E}-03$ & $4.0 \mathrm{E}-03$ & $4.0 \mathrm{E}-03$ \\
\hline $\mathrm{Cl}$ & 3.7E-02 & $8.9 \mathrm{E}-02$ & $3.7 \mathrm{E}-02$ \\
\hline $\mathrm{Cr}$ & $6.9 \mathrm{E}-03$ & $2.0 \mathrm{E}-02$ & $6.9 \mathrm{E}-03$ \\
\hline $\mathrm{F}$ & 9.1E-02 & $2.0 \mathrm{E}-01$ & 9.1E-02 \\
\hline $\mathrm{Fe}$ & $1.0 \mathrm{E}-02$ & $1.0 \mathrm{E}-02$ & $1.0 \mathrm{E}-02$ \\
\hline $\mathrm{Hg}$ & $1.4 \mathrm{E}-05$ & $1.4 \mathrm{E}-05$ & $1.4 \mathrm{E}-05$ \\
\hline $\mathrm{K}$ & $1.8 \mathrm{E}-01$ & $1.8 \mathrm{E}-01$ & $1.8 \mathrm{E}-01$ \\
\hline $\mathrm{La}$ & 8.3E-05 & 8.3E-05 & 8.3E-05 \\
\hline $\mathrm{Ni}$ & $3.0 \mathrm{E}-03$ & $3.0 \mathrm{E}-03$ & $3.0 \mathrm{E}-03$ \\
\hline $\mathrm{NO}_{2}$ & $3.8 \mathrm{E}-01$ & $3.8 \mathrm{E}-01$ & $3.8 \mathrm{E}-01$ \\
\hline $\mathrm{NO}_{3}$ & 8.0E-01 & 8.0E-01 & $8.0 \mathrm{E}-01$ \\
\hline $\mathrm{OH}$ & $7.0 \mathrm{E}-01$ & 7.0E-01 & $7.0 \mathrm{E}-01$ \\
\hline $\mathrm{Pb}$ & $6.8 \mathrm{E}-04$ & $6.8 \mathrm{E}-04$ & $6.8 \mathrm{E}-04$ \\
\hline $\mathrm{PO}_{4}$ & $3.8 \mathrm{E}-02$ & $1.3 \mathrm{E}-01$ & $3.8 \mathrm{E}-02$ \\
\hline $\mathrm{SO}_{4}$ & 9.7E-03 & $7.0 \mathrm{E}-02$ & $2.0 \mathrm{E}-02$ \\
\hline TIC & $3.0 \mathrm{E}-01$ & $3.0 \mathrm{E}-01$ & $3.0 \mathrm{E}-01$ \\
\hline TOC $^{1}$ & $6.0 \mathrm{E}-02$ & $6.0 \mathrm{E}-02$ & $5.0 \mathrm{E}-01$ \\
\hline $\mathrm{U}$ & $1.2 \mathrm{E}-03$ & $1.2 \mathrm{E}-03$ & $1.2 \mathrm{E}-03$ \\
\hline
\end{tabular}

${ }^{1}$ For each atom of Carbon in TOC. 
HNF-2799

Revision 0

Table 2. Low-Activity Waste Feed Liquid Phase Radionuclide Content.

\begin{tabular}{|c|c|c|c|}
\hline & \multicolumn{3}{|c|}{ Maximum ratio, radionuclide (Bq) to sodium (mole) } \\
\hline Radionuclide $^{1}$ & Envelope A & Envelope B & Envelope C \\
\hline $\mathrm{TRU}^{2}$ & $4.8 \mathrm{E}+05$ & $4.8 \mathrm{E}+05$ & $3.0 \mathrm{E}+06$ \\
\hline${ }^{137} \mathrm{Cs}$ & $4.3 \mathrm{E}+09$ & $6.0 \mathrm{E}+10$ & $4.3 \mathrm{E}+09$ \\
\hline${ }^{90} \mathrm{Sr}$ & $4.4 \mathrm{E}+07$ & $4.4 \mathrm{E}+07$ & $8.0 \mathrm{E}+08$ \\
\hline${ }^{99} \mathrm{Tc}$ & $7.1 \mathrm{E}+06$ & $7.1 \mathrm{E}+06$ & $7.1 \mathrm{E}+06$ \\
\hline
\end{tabular}

${ }^{1}$ Some radionuclides, such as ${ }^{90} \mathrm{Sr}$ and ${ }^{137} \mathrm{Cs}$, have daughters with relatively short half-lives. These daughters have not been listed in this table. However, they are present in concentrations associated with the normal decay chains of the radionuclides.

${ }^{2}$ Radionuclides contributing to TRU are those alpha-emitting transuranic radionuclides with half-lives greater than 5 years ${ }^{236} \mathrm{~Np}$, ${ }^{237} \mathrm{~Np},{ }^{238} \mathrm{Pu},{ }^{239} \mathrm{Pu},{ }^{240} \mathrm{Pu}$, ${ }^{242} \mathrm{Pu},{ }^{244} \mathrm{Pu},{ }^{241} \mathrm{Am},{ }^{242 \mathrm{~m}} \mathrm{Am},{ }^{243} \mathrm{Am},{ }^{243} \mathrm{Cm},{ }^{244} \mathrm{Cm},{ }^{245} \mathrm{Cm},{ }^{246} \mathrm{Cm}$, and ${ }^{247} \mathrm{Cm}$ ). ${ }^{238} \mathrm{Pu},{ }^{239} \mathrm{Pu},{ }^{240} \mathrm{Pu}$ and ${ }^{241} \mathrm{Am}$ are expected to comprise $>95$ percent of the total measured activity. ${ }^{242 \mathrm{~m}} \mathrm{Am}$ and ${ }^{244} \mathrm{Cm}$ are expected to contribute less than 2 percent of the total measured alpha activity. ${ }^{236} \mathrm{~Np},{ }^{245} \mathrm{Cm},{ }^{246} \mathrm{Cm}$, and ${ }^{247} \mathrm{Cm}$ are not expected to be present in Hanford nuclear waste in measurable quantities. Measurement of total alpha activity may provide an adequate screening for comparison with the TRU envelope limit. 
HNF-2799

Revision 0

Table 3. Applicable Waste Composition Limits from OSD-T-151-00007 (PHMC 1997).

\subsubsection{TANK COMPOSITION}

7.2.1.A Temperatures $\left(\mathrm{T} \leq 212^{\circ} \mathrm{F}\right)$

Variable $\quad$ Specification Limit

For $\left[\mathrm{NO}_{3}{ }^{-}\right] \leq 1.0 \mathrm{M}$ :

$$
\begin{array}{ll}
{\left[\mathrm{OH}^{-}\right]} & 0.010 \mathrm{M} \leq\left[\mathrm{OH}^{-}\right] \leq 5.0 \mathrm{M} \\
{\left[\mathrm{NO}_{2}^{-}\right]} & 0.011 \underline{\mathrm{M}} \leq\left[\mathrm{NO}_{2}^{-}\right] \leq 5.5 \mathrm{M} \\
{\left[\mathrm{NO}_{3}^{-}\right] /\left(\left[\mathrm{OH}^{-}\right]+\left[\mathrm{NO}_{2}^{-}\right]\right)} & <2.5
\end{array}
$$

(for solutions below $167^{\circ} \mathrm{F}$, the $\left[\mathrm{OH}^{-}\right]$limit is $8.0 \mathrm{M}$ )

For $1.0 \underline{\mathrm{M}}<\left[\mathrm{NO}_{3}^{-}\right] \leq 3.0 \underline{\mathrm{M}}$ :

$\left[\mathrm{OH}^{-}\right]$

$\left[\mathrm{OH}^{-}\right]+\left[\mathrm{NO}_{2}^{-}\right]$

For $\left[\mathrm{NO}_{3}{ }^{-}\right]>3.0 \mathrm{M}$ :

$\begin{array}{ll}{\left[\mathrm{OH}^{-}\right]} & 0.3 \mathrm{M} \leq\left[\mathrm{OH}^{-}\right]<10 \mathrm{M} \\ {\left[\mathrm{OH}^{-}\right]+\left[\mathrm{NO}_{2}^{-}\right]} & \geq 1.2 \mathrm{M} \\ {\left[\mathrm{NO}_{3}^{-}\right]} & \leq 5.5 \mathrm{M}\end{array}$

\subsubsection{HEAT GENERATIONRATE}

\section{$\underline{\text { Variable }}$}

1) Maximum Heat Generation Rate

2) Max. Concentration

Cesium-137 (Cs-137)

3) Max. Concentration Strontium-90 (Sr-90)

\section{Specification Limit*}

70,000 BTU/hr, for 241-AN, AP and AW.

$50,000 \mathrm{BTU} / \mathrm{hr}$, for $241-\mathrm{SY}$.

$5.74 \times 10^{5} \mu \mathrm{Ci} / \mathrm{L}$ for $241-\mathrm{AN}, \mathrm{AP}$, and $\mathrm{AW}$.

$4.10 \times 10^{5} \mu \mathrm{Ci} / \mathrm{L}$ for $241-\mathrm{SY}$.

$4.04 \times 10^{5} \mu \mathrm{Ci} / \mathrm{L}$ for $241-\mathrm{AN}, \mathrm{AP}$, and $\mathrm{AW}$.

$2.88 \times 10^{5} \mu \mathrm{Ci} / \mathrm{L}$ for $241-\mathrm{SY}$ 
HNF-2799

Revision 0

\subsection{REFERENCES}

Certa, P. J., and J. Jo,1998, Data Quality Objectives for TWRS Privatization Phase I: Confirm Tank $T$ is an Appropriate Feed source for Low-Activity Waste Feed Batch X, HNF-1796 Rev. 1, Numatec Hanford Corporation, Richland, Washington.

PHMC, 1997, Unclassified Operating Specifications for the 241-AN,AP,AW,AY,AZ, and SY Tank Farms, OSD-T-151-00007, Fluor Daniel Hanford, Richland, Washington. 
HNF-2799

Revision 0

This page intentionally left blank. 


\section{ADDENDUM 1}

\section{APPLICATION OF}

\section{"CONFIRM TANK T IS AN APPROPRIATE FEED SOURCE FOR LOW-ACTIVITY WASTE FEED BATCH $X "$}

TO

241-AN-105 / BATCH 1 


\section{HNF-2799}

Revision 0

This page intentionally left blank.

Addendum 1-2 
CONTENTS

1.0 INTRODUCTION $\ldots \ldots \ldots \ldots \ldots \ldots \ldots \ldots \ldots \ldots \ldots \ldots \ldots \ldots$ Addendum $1-5$

2.0 EVALUATION . . . . . . . . . . . . . . . . . . Addendum $1-7$

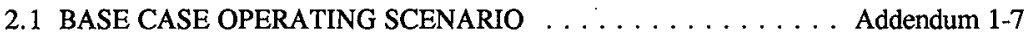

2.2 ALTERNATIVE CASE OPERATING SCENARIO $\ldots \ldots \ldots$. . . Addendum 1-8

3.0 REFERENCES $\ldots \ldots \ldots \ldots \ldots \ldots \ldots \ldots \ldots$. . . . . . . . . . . . . . . . 1 .

\section{LIST OF TABLES}

1. Base Case Operating Scenario Evaluation. . . . . . . . . Addendum 1-10

2. Alternative Case Operating Scenario Evaluation. . . . . . . . . . Addendum 1-19

3. Information Needs. $\ldots \ldots \ldots \ldots \ldots \ldots \ldots \ldots \ldots$ Addendum $1-26$ 
HNF-2799

Revision 0

\section{LIST OF TERMS}

DOE U.S. Department of Energy

ICD Interface Control Document

LAW Low-Activity Waste

M Molar (gmoles/liter)

PHMC Project Hanford Management Contract(or)

PMBS Project Master Baseline Schedule

PSDQO Problem-Specific Data Quality Objectives

RL U.S. Department of Energy-Richland Operations

TANK $\mathrm{T} \quad$ Refers to the contents from one tank, multiple tanks, or portions of one or more tanks that will be used to prepare a feed batch

TOC Total Organic Carbon

TWRS Tank Waste Remediation System

TWRSO\&UP Tank Waste Remediation System Operation and Utilization Plan

USQ Unreviewed Safety Question

WIT Waste Disposal Integration Team

WTC Whole tank composite 
HNF-2799

Revision 0

\section{APPLICATION OF "CONFIRM TANK T IS AN APPROPRIATE FEED SOURCE FOR LOW-ACTIVITY WASTE FEED BATCH X" TO 241-AN-105 / BATCH 1}

\subsection{INTRODUCTION}

This addendum applies Revision 0 of "Confirm Tank $\mathrm{T}$ is an Appropriate Feed Source for Low-Activity Waste Feed Batch X" problem-specific data quality objectives (PSDQO) to tank 241-AN-105 / Batch 1.

This application will also serve as a user test for the PSDQO since it is the first time the PSDQO will be applied.

This application of PSDQO-01 is divided into a Base Case Operating Scenario and an Alternative Case Operating Scenario. The Base Case homogenizes the waste in tank 241-AN-105 by mixing prior to transfer to 241-AP-102 and -104. The Alternative Case transfers the tank 241-AN-105 supernate to 241-AP-102 and -104 without mixing followed by subsequent diluent addition and mixing in 241-AN-105 before transfer to 241-AP-102 and -104 . 
HNF-2799

Revision 0

This page intentionally left blank.

Addendum 1-6 
HNF-2799

Revision 0

\subsection{EVALUATION}

\subsection{BASE CASE OPERATING SCENARIO}

Translate the operating scenario into a series of process steps.

The base case operating scenario from the Tank Waste Remediation System Operation and Utilization Plan (TWRSO\&UP) (Kirkbride et al. 1997) includes the following steps to make up Batch 1:

- Empty, flush, and empty 241-AP-102 and -104 (the feed staging tanks) leaving a dilute, $0.1 \mathrm{ML}(10$-in.) heel behind in each tank.

- Homogenize the waste in $241-\mathrm{AN}-105$ using mixer pumps to resuspend the salt slurry.

- Transfer half of the homogenized waste in 241-AN-105 to 241-AP-102 and the remaining half to $241-\mathrm{AP}-104$, leaving a $0.1 \mathrm{ML}$ (10-in.) heel. During the transfer, the proper amount of diluent will be added to the waste at the transfer pump inlet.

- Mix the waste in 241-AP-102 and mix the waste in 241-AP-104.

- Allow undissolved solids to settle.

The dilute heel in 241-AP-102 and -104 can be neglected for the purposes of this PSDQO; how clean the staging tank needs to be is an operational issue, not a "Confirm Tank T..." issue.

Define the waste that applies to each element in the decision rule.

Element 1, Dilution Ratio and Diluent Composition: this applies to the whole tank composite (WTC) of 241-AN-105 over the temperature range of 25 to $65^{\circ} \mathrm{C}$.

Element 2, Transfer Requirements: there are two nearly identical transfers; they will be treated as one transfer. Transfer requirements apply to a whole tank composite of the waste currently in 241-AN-105 after addition of the proper amount of diluent over the temperature range of 25 to $65^{\circ} \mathrm{C}$.

Element 3, Mixing Requirements: the mixing requirement applies to a salt slurry composite of the waste currently in $241-\mathrm{AN}-105$ over the temperature range of 25 to $65{ }^{\circ} \mathrm{C}$.

Element 4, Envelope Requirements: there is one unique Batch 1 composition; the composition and physical properties are that of a whole tank composite of the waste currently 
HNF-2799

Revision 0

in 241-AN-105 after addition of the proper amount of diluent over the temperature range of 25 to $65^{\circ} \mathrm{C}$. The dilute heel in 241-AP-102 and -104 can be neglected for the purposes of this PSDQO (all current data strongly indicate that the 241-AP-102 and -104 heel will not interfere with staging the compositionally correct feed); how clean the tank needs to be is an operational issue, not a "Confirm Tank T..." issue.

Element 5, Miscellaneous Inputs: These inputs apply to the whole tank composition of 241-AN-105 or to changes in the operating scenario that may be imposed in the future.

Evaluate existing data and determine information needs.

Table 1 contains the evaluation of the base case operating scenario for all the elements of the decision rules found in Section 6 of the PSDQO. The table lists each element taken from Section 6.1 of the PSDQO. For each element, the requirements specific to 241-AN-105 / Batch 1 are listed. Each requirement is evaluated against existing data and the remaining information needs are identified. The information needs are summarized in Table 3.

\subsection{ALTERNATIVE CASE OPERATING SCENARIO}

Translate the operating scenario into a series of process steps.

The TWRSO\&UP (Kirkbride et al. 1997) recommended that process control issues be taken into account. This alternative case operating scenario was developed based on consideration of process control issues and is currently being evaluated and incorporated into the project master baseline schedule and corresponding logic diagrams. The steps that directly affect the composition of Batch 1 are listed below:

- Empty, flush, and empty 241-AP-102 and -104 (the feed staging tanks) leaving a dilute, $0.1 \mathrm{ML}(10$-in.) heel behind in each tank.

- Decant the supernate in 241-AN-105; transfer half of the supernate to 241-AP-102 and the remainder to 241-AP-104, leaving a 10-in. heel above the salt slurry. During these transfers diluent will be added to the waste at the pump inlet.

- Add diluent to the salt slurry in 241-AN-105 and mix.

- Allow undissolved solids to settle in 241-AN-105.

- Transfer half of the liquid in 241-AN-105 to 241-AP-102 and the remaining to 241-AP-104, leaving a 10-in. heel. No additional diluent is expected to be needed for the transfer.

- Mix the waste in 241-AP-102 and mix the waste in 241-AP-104. 
HNF-2799

Revision 0

- Allow any undissolved solids that were inadvertently entrained to settle in 241-AP-102 and -104 .

The dilute heel in 241-AP-102 and -104 can be neglected for the purposes of this PSDQO; how clean the tank needs to be is an operational issue, not a "Confirm Tank T..." issue.

Define the waste that applies to each element in the decision rule.

Element 1, Dilution Ratio and Diluent Composition: this applies to (a) a supernate composite from 241-AN-105 and (b) a salt slurry composite from 241-AN-105, both over the temperature range of 25 to $65^{\circ} \mathrm{C}$.

Element 2, Transfer Requirements: out of four transfers, there are two distinct transfers. The transfer requirements applies to (a) supernate composite from 241-AN-105 after addition of the proper amount of diluent and (b) a salt slurry composite from 241-AN-104 after addition of the proper amount of diluent and settling of undissolved solids over the temperature range of 25 to $65^{\circ} \mathrm{C}$.

Element 3, Dissolution Requirements: the dissolution requirements applies to the whole tank composite of the waste currently in 241-AN-105 over the temperature range of 25 to $65^{\circ} \mathrm{C}$.

Element 4, Envelope Requirements: there is one unique Batch 1 composition; the composition and physical properties are that of a whole tank composite of the waste currently in 241-AN-105 after addition of the proper amount of diluent over the temperature range of 25 to $65^{\circ} \mathrm{C}$. The dilute heel in 241-AP-102 and -104 can be neglected for the purposes of this PSDQO (all current data strongly indicate that 241-AP-102 and -104 heel will not interfere with staging the compositionally correct feed); how clean the tank needs to be is an operational issue, not a "Confirm Tank T..." issue.

Element 5, Miscellaneous Inputs: these inputs apply to the whole tank composition of 241-AN-105 or to changes in the operating scenario that may be imposed in the future.

Evaluate existing data and determine information needs.

Table 2 contains the evaluation of the alternative case operating scenario for all the elements of the decision rule found in Section 6 of the PSDQO for Confirm Tank T. The table lists each element of the decision rule taken from Section 6.1 of the PSDQO. For each element, the requirements specific to $241-\mathrm{AN}-105$ / Batch 1 are listed. Each requirement is evaluated against existing data and remaining information needs are identified. The information needs are developed more fully in Table 3. 
Table 1. Base Case Operating Scenario Evaluation. (9 Sheets)

\begin{tabular}{|c|c|c|c|}
\hline Elements ${ }^{\mathrm{a}}$ & Requirements ${ }^{\mathrm{b}}$ & Discussion/evaluation & $\begin{array}{l}\text { Information } \\
\text { needs }\end{array}$ \\
\hline $\begin{array}{l}\text { Element } 1 \text {, Dilution } \\
\text { Ratio and Diluent } \\
\text { Composition }\end{array}$ & $\begin{array}{l}\text { Determine the desired dilution ratio } \\
\text { and diluent composition for each } \\
\text { waste transfer. }\end{array}$ & $\begin{array}{l}\text { A process test was performed (Herting 1997a). The test was conducted in } \\
\text { accordance with a test plan (Herting 1997b). The test plan was based on } \\
\text { instruction provided by the Disposal Program (Garfield 1997). The whole tank } \\
\text { composite (WTC) results of this test apply to the Base case operating scenario. } \\
\text { The test determined that the required dilution ratio }{ }^{1} \text { is } 50-75 \% \text { and that the } \\
\text { desired diluent is water. } \\
\text { Dilution ration and Diluent composition established. }\end{array}$ & $\begin{array}{l}\text { No further } \\
\text { information is } \\
\text { needed. }\end{array}$ \\
\hline \multirow[t]{2}{*}{$\begin{array}{l}\text { Element 2, Transfer } \\
\text { Requirements }\end{array}$} & $\begin{array}{l}\text { Confirm that the as-retrieved waste } \\
\text { (including dilution water or caustic) } \\
\text { remains below saturation in major } \\
\text { Na salts during the transfer to the } \\
\text { staging tank. }\end{array}$ & $\begin{array}{l}\text { Herting (1997a, Section 5.3.3) found that beyond a dilution ration of } 50 \% \text { for } \\
\text { the WTC the supernate is below saturation in major Na salts. } \\
\text { Below saturation established. }\end{array}$ & $\begin{array}{l}\text { No further } \\
\text { information is } \\
\text { needed. }\end{array}$ \\
\hline & $\begin{array}{l}\text { Confirm that the as-retrieved waste } \\
\text { (including dilution water or caustic) } \\
\text { remain at or below viscosity of } \\
10 \mathrm{cP} \text {, at or below a } 1.5 \mathrm{SpG} \text {, and at } \\
\text { or below } 30 \text { percent solids by } \\
\text { volume during the transfer to the } \\
\text { staging tank. }\end{array}$ & $\begin{array}{l}\text { Herting (1997a, Section } 3.3 .1 \text { ) found that the viscosity of the WTC at a } 50 \% \\
\text { dilution ratio over the temperature range of } 28 \text { to } 65^{\circ} \mathrm{C} \text { varies from } 2.5 \text { to } \\
6.0 \mathrm{cP} \text {. All samples exhibited Newtonian behavior. Continued dilution to } 75 \% \\
\text { is expected to further reduce the viscosity since no additional solids were } \\
\text { observed to precipitate. } \\
\text { The largest observed quantity of settled solids that Herting (1997a, Table } 4-1 \text { ) } \\
\text { observed for WTC dilutions of } 50 \% \text { and } 70 \% \text { at temperatures of } 25,45 \text {, and } \\
65{ }^{\circ} \mathrm{C} \text { at } 20 \text { hours after mixing was } 15 \text { volume } \% \text {. } \\
\text { Herting ( } 1997 \mathrm{a}, \text { Section } 3.1 \text { ) found that the liquid phase density for WTC } \\
\text { dilutions of } 50 \% \text { and } 75 \% \text { performed at temperatures of } 25,45 \text { and } 65^{\circ} \mathrm{C} \\
\text { ranged from } 1.28 \text { to } 1.39 \mathrm{~g} / \mathrm{ml} \text {. Bulk densities calculated from the raw data in } \\
\text { this section range from } 1.30 \text { to } 1.39 \mathrm{~g} / \mathrm{ml} \text {. These values are less than the limit } \\
\text { by more than } 0.05 \mathrm{~g} / \mathrm{ml} \text {. Correction for reference conditions for SpG are not } \\
\text { important. } \\
\text { Viscosity, SpG, suspended solids no concern. }\end{array}$ & $\begin{array}{l}\text { No further } \\
\text { information is } \\
\text { needed. }\end{array}$ \\
\hline
\end{tabular}

${ }^{1}$ In this addendum, a dilution ratio is the volume ratio of diluent to undiluted waste expressed as a percentage. 
Table 1. Base Case Operating Scenario Evaluation. (9 Sheets)

\begin{tabular}{|c|c|c|c|}
\hline Elements ${ }^{a}$ & Requirements ${ }^{b}$ & Discussion/evaluation & $\begin{array}{l}\text { Information } \\
\text { needs }\end{array}$ \\
\hline $\begin{array}{l}\text { Element 2, Transfer } \\
\text { Requirements } \\
\text { (continued) }\end{array}$ & $\begin{array}{l}\text { Confirm that the dilution ratio, } \\
\text { diluent composition, and waste } \\
\text { composition are balanced so gibbsite } \\
\text { or high viscosity slurries do not } \\
\text { precipitate }\end{array}$ & $\begin{array}{l}\text { Herting (1997a, Section } 2.2) \text { did not observe precipitation during extended } \\
\text { storage ( } 4-8 \text { weeks) of supernate sub-samples from the WTC dilution tests at } 0 \text {, } \\
25,50 \text { and } 75 \% \text { dilution at temperatures of } 25,45 \text { and } 65{ }^{\circ} \mathrm{C} \text {. This covers all } \\
\text { practical dilution ratios. } \\
\text { Special Consideration: If gibbsite will form, it should form within four weeks. } \\
\text { Samples were observed for } 4-8 \text { weeks. } \\
\text { No precipitation concern. }\end{array}$ & $\begin{array}{l}\text { No further } \\
\text { information is } \\
\text { needed. }\end{array}$ \\
\hline $\begin{array}{l}\text { Element 3, Mixing } \\
\text { Requirements }\end{array}$ & $\begin{array}{l}\text { Confirm that the portion of the } \\
\text { solids thought to be soluble are } \\
\text { soluble and that they dissolve in a } \\
\text { reasonable amount of time. }\end{array}$ & $\begin{array}{l}\text { The Base case operating scenario (Kirkbride et al. 1997) assumed that the } \\
\text { majority of the solids in } 241-\mathrm{AN}-105 \text { would dissolve. Herting (1997a, Table } \\
4-5 \text { ) found that the undissolved solids at } 50 \text { and } 75 \% \text { dilution for temperatures } \\
\text { of } 25,45 \text { and } 65^{\circ} \mathrm{C} \text { varies from } 0.2-0.4 \text { true wt } \% \text { (the undiluted samples } \\
\text { ranged from } 3.8-4.8 \text { true wt } \% \text { ). This is consistent with the Base case } \\
\text { operating scenario which has } 3 \text { wt } \% \text { solids in the undiluted waste and } 0.5 \text { wt } \% \\
\text { solids after dilution. } \\
\text { Herting (1997a, Section 1.1) found that dissolution kinetic were very fast } \\
\text { (dissolution was complete after about } 15 \text { seconds). } \\
\text { Note: Confirmation that a mixer pump can provide the necessary amount of } \\
\text { mixing to dissolve the solids in the tank in a reasonable amount of time is within } \\
\text { the scope of the Equipment Design PSDQO. } \\
\text { Solids solubility no concern. }\end{array}$ & $\begin{array}{l}\text { No further } \\
\text { information is } \\
\text { needed. }\end{array}$ \\
\hline
\end{tabular}


Table 1. Base Case Operating Scenario Evaluation. (9 Sheets)

\begin{tabular}{|c|c|c|c|}
\hline Elements ${ }^{\mathbf{a}}$ & Requirements ${ }^{\mathbf{b}}$ & Discussion/evaluation & $\begin{array}{l}\text { Information } \\
\text { needs }\end{array}$ \\
\hline \multirow[t]{2}{*}{$\begin{array}{l}\text { Element 3, Mixing } \\
\text { Requirements } \\
\text { (continued) }\end{array}$} & $\begin{array}{l}\text { Confirm that the undissolved solids } \\
\text { settle and that they settle in a } \\
\text { reasonable amount of time. }\end{array}$ & $\begin{array}{l}\text { Herting (1997a, Section 3.1) found that the undissolved solids will settle and do } \\
\text { so in about } 20 \text { hrs. } \\
\text { Scale-up calculations for Herting's settling data have not been performed. } \\
\text { The base case time allocated in the TWRSO\&UP (Kirkbride et al. 1997, } \\
\text { Assumption } 6.11 \text { ) for settling is taken by reference from (Certa et al. 1996) } \\
\text { and is } 30 \text { days. } \\
\text { Special Consideration: The dissolved air in the dilution water was salted out } \\
\text { when mixed with the undiluted waste. The resulting foam kept a portion of the } \\
\text { solids from settling. The foam dispersed and solids settled upon mixing again. }\end{array}$ & $\begin{array}{l}\text { Estimated time } \\
\text { to settle } \\
\text { undissolved } \\
\text { solids at full } \\
\text { scale. (See } \\
\text { Table 3, } \\
\text { Item \# 1). }\end{array}$ \\
\hline & $\begin{array}{l}\text { Confirm that the baseline retrieval } \\
\text { equipment that will be used to } \\
\text { mobilize and transfer the waste is } \\
\text { consistent with the operating } \\
\text { scenario. }\end{array}$ & $\begin{array}{l}\text { Tank } 241 \text {-AN- } 105 \text { contains about } 40 \% \text { by volume of a salt slurry. The best } \\
\text { basis inventory also shows that the salt slurry contains approximately } 40 \% \text { of } \\
\text { the total sodium (Jo 1997). The base case operating scenario targets most of the } \\
\text { sodium in the salt slurry for feed. The equipment required to mobilize and } \\
\text { retrieve the slurry includes mixer pumps and a transfer pump with water (and } \\
\text { caustic) dilution capability (Boston 1997). This is consistent with the equipment } \\
\text { identified in the base case operating scenario (Kirkbride et al. 1997). } \\
\text { Retrieval equipment to be added to } 241 \text {-AN-105 will accomplish requirements. }\end{array}$ & $\begin{array}{l}\text { No further } \\
\text { information is } \\
\text { needed. }\end{array}$ \\
\hline
\end{tabular}


Table 1. Base Case Operating Scenario Evaluation. (9 Sheets)

\begin{tabular}{|c|c|c|c|}
\hline Elements $^{a}$ & Requirements ${ }^{\mathbf{b}}$ & Discussion/evaluation & $\begin{array}{l}\text { Information } \\
\text { needs }\end{array}$ \\
\hline $\begin{array}{l}\text { Element } 4 \text { - Part } 1 \text { : } \\
\text { Envelope Requirements } \\
\text { These limits apply to } \\
\text { the feed actually } \\
\text { delivered to the private } \\
\text { contractors. }\end{array}$ & $\begin{array}{l}\text { Concentration limits for the } \\
\text { chemical and radionuclide content of } \\
\text { the feed (DOE-RL 1996, Section } \\
\text { C.6). } \\
\text { See Section } 2.0 \text {, Tables } 1 \text { and } 2 \text { (in } \\
\text { main report) for the limits. }\end{array}$ & $\begin{array}{l}\text { Only Envelope A limits apply to Batch } 1 . \\
\text { The TWRSO\&UP (Kirkbride et al. 1997, Tables I-1 and I-3)) compared the } \\
\text { point estimates }{ }^{1} \text { of the composition of the feed from } 241 \text {-AN-105 to the } \\
\text { Envelope limits and "flagged" TOC as requiring further examination. The TOC } \\
\text { was at } 82 \% \text { of the maximum limit of } 0.06 \text { gmole TOC/gmole Na; All other } \\
\text { analytes were below } 80 \% \text { of their maximum limits. } \\
\text { Resolution of "flag": (1) TOC was not identified as a problem by Welsh } \\
\text { (1997) or by Herting (1997a); (2) RL is negotiating an increase in the } \\
\text { TOC limit from } 0.06 \text { gmole TOC/gmole Na to } 0.5 \text { gmole TOC/gmole } \\
\text { Na. } \\
\text { Welsh (1997, Section 7.1 and 7.2) calculated the mean concentration and UL } 2 \\
\text { for the bulk tank composition }{ }^{3} \text { using four variations on segment data and two } \\
\text { variations on composite data. The means and UL for all analytes and methods } \\
\text { were below the maximum envelope limits, with the following exception: In two } \\
\text { variations based on segment data that used fusion digest slurry data the means } \\
\text { for Ba.icp and La.icp and the UL for Ba.icp, La.icp, Ni.icp.wo, Pb.icp.w and } \\
\text { Pb.icp.wo exceeded their respective envelope limits. These are "flagged" for } \\
\text { further consideration. }\end{array}$ & $\begin{array}{l}\text { No further } \\
\text { information is } \\
\text { needed. }\end{array}$ \\
\hline
\end{tabular}

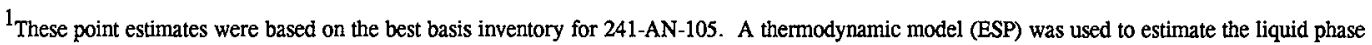
composition of the diluted waste.

${ }^{2}$ The $\mathrm{UL}$ is the upper 95 percent confidence interval for random variability.

3 For 241-AN-105, the bulk inventory can be used as a bounding case in estimating the analyte:Na ratios. The quantity of each bulk analyte inventory will be equal to or greater than that in the liquid phase of the diluted waste. The bulk quantity of sodium in the tank will be about the same as the sodium in the liquid phase after dilution with water since nearly all of the sodium has been removed from the solids at a $50 \%$ or greater dilution. Any bias in the analyte:Na moie ratios estimated directly from the bulk inventory will tend to be high (that is, conservative for comparison to maximum envelope limits). 
Table 1. Base Case Operating Scenario Evaluation. (9 Sheets)

\begin{tabular}{|c|c|c|c|}
\hline Elements $^{\mathrm{a}}$ & Requirements $^{\mathbf{b}}$ & Discussion/evaluation & $\begin{array}{l}\text { Information } \\
\text { needs }\end{array}$ \\
\hline $\begin{array}{l}\text { Element } 4 \text { - Part 1: } \\
\text { Envelope Requirements } \\
\text { (continued) }\end{array}$ & $\begin{array}{l}\text { Concentration limit for the sodium } \\
\text { concentration of the feed: } \\
3 \underline{M} \leq[\mathrm{Na}] \leq 14 \underline{\mathrm{M}} \text { (DOE-RL } \\
1996 \text {, Section C.6). }\end{array}$ & $\begin{array}{l}\text { Resolution of "flag": (1) The fusion digest results are overly } \\
\text { conservative in that they dissolve essentially all solids while the } \\
\text { alternative method (acid digest) dissolves all water soluble solids and } \\
\text { most other solids. (2) The fusion digest method results in large "less } \\
\text { than" values due to the additional dilution of the sample (about an order } \\
\text { of magnitude greater than the acid digest). } \\
\text { Herting (1997a, Section } 1.0 \text { ) found that "under all dilution conditions studied, } \\
\text { the retrievable waste fell within the feed specification limits established for } \\
\text { Envelope A in the Phase I Privatization contracts". } \\
\text { Compliance with Envelope A achieved. c Herting (1997a, Table } 8 \text {-1) found } \\
\text { that the [Na] is } 7.56 \mathrm{M} \text { for a } 50 \% \text { dilution ratio and } 6.57 \underline{\mathrm{M}} \text { for } 75 \% \text { dilution. } \\
\text { The worst case (for the various statistical models and analytical methods } \\
\text { employed) estimate of bulk [Na] is a mean of } 12.7 \mathrm{M} \text { with a } 95 \% \mathrm{CI} \text { around the } \\
\text { mean of } 10.3 \mathrm{M}-15.2 \mathrm{M} \text { (Welsh } 1997 \text {, Section } 7 \text { ). Dilution of waste with a } \\
\text { 15.2 } \mathrm{M} \text { [Na] at a } 50 \% \text { dilution ration will yield a [Na] of } 10.1 \mathrm{M} \text {. } \\
\text { Compliance with Na molarity achieved. }\end{array}$ & $\begin{array}{l}\text { No further } \\
\text { information is } \\
\text { needed. }\end{array}$ \\
\hline
\end{tabular}


Table 1. Base Case Operating Scenario Evaluation. (9 Sheets)

\begin{tabular}{|c|c|c|c|}
\hline Elements ${ }^{\mathbf{a}}$ & Requirements ${ }^{\mathrm{b}}$ & Discussion/evaluation & $\begin{array}{l}\text { Information } \\
\text { needs }\end{array}$ \\
\hline $\begin{array}{l}\text { Element } 4 \text { - Part 1: } \\
\text { Envelope Requirements } \\
\text { (continued) }\end{array}$ & $\begin{array}{l}\text { Insoluble solids fraction limit will } \\
\text { not exceed } 5 \text { volume \% (DOE-RL } \\
\text { 1996, Section C.6). }\end{array}$ & $\begin{array}{l}\text { The contracts do not define how the volume percent insoluble solids will be } \\
\text { measured. } \\
\text { Herting (1997a, Table 4-1) measured the quantity of solids and expressed the } \\
\text { results several difference ways. The ranges given below are for WTC dilutions } \\
\text { of } 50 \% \text { and } 70 \% \text { at temperatures of } 25,45 \text { and } 65{ }^{\circ} \mathrm{C} \text { at } 20 \text { hours after mixing: } \\
9-15 \text { volume } \% \text { settle solids } \rightarrow \text { "Flagged" } \\
3-7 \text { volume \% centrifuges solids } \rightarrow \text { "Flagged" } \\
2.6 \text { to } 3.6 \text { weight \% centrifuged solids (wet) } \\
0.2 \text { to } 0.6 \text { weight \% true solids. } \\
\text { Resolution of "Flag": (1) The PHMC will use the decant system planned } \\
\text { for the intermediate feed staging tanks (Britton et al. 1996) for control of } \\
\text { solids in the feed delivered to the private contractors, if needed. (2) Issue } \\
19 T \text { of ICD } 19 \text { (PHMC 1997a) addresses this solids measurement issue. } \\
\text { RL is negotiating a change in this limit from volume \% to weight } \\
\text { percent. }\end{array}$ & $\begin{array}{l}\text { No further } \\
\text { information is } \\
\text { needed. }\end{array}$ \\
\hline
\end{tabular}


Table 1. Base Case Operating Scenario Evaluation. (9 Sheets)

\begin{tabular}{|c|c|c|c|}
\hline Elements $^{a}$ & Requirements $^{b}$ & Discussion/evaluation & $\begin{array}{l}\text { Information } \\
\text { needs }\end{array}$ \\
\hline \multirow[t]{2}{*}{$\begin{array}{l}\text { Element } 4 \text { - Part 1: } \\
\text { Envelope Requirements } \\
\text { (continued) }\end{array}$} & $\begin{array}{l}\text { Operating Specifications from } \\
\text { OSD-T-151-00007 (DOE-RL 1996, } \\
\text { Section C.6 invokes the OSD by } \\
\text { reference). } \\
\text { See Section 2.0, Table } 3 \text { (in main } \\
\text { report). }\end{array}$ & $\begin{array}{l}\text { The contract does not explicitly state which specifications from the OSD apply } \\
\text { to the waste. The PHMC assumes that the Tank Composition (7.2.1) and Heat } \\
\text { Generation Rate (7.2.8) limits apply to the waste. These limits are shown in } \\
\text { Section } 2.0 \text {, Table } 3 \text { (in main report). } \\
\text { The TWRSO\&UP (Kirkbride et al. 1997, Section 3.1.1.6) compared the point } \\
\text { estimates of the composition of the waste as staged in } 241 \text {-AP-102 and -104 } \\
\text { with the Tank Composition (Tank Corrosion) specifications. All limits were } \\
\text { satisfied for Batch } 1 \text {. Uncertainty is not an issue since the [OH], [NO }{ }_{2} \text { ] and } \\
\text { [NO }{ }_{3} \text { ] in the staging tanks can be adjusted if needed before the feed } \\
\text { qualification samples are taken. } \\
\text { The TWRSO\&UP (Section } 3.1 .1 .6 \text { ) also evaluated the heat generation rate rule } \\
\text { and found that all limits were satisfied for Batch } 1 \text {, decayed to the estimated } \\
\text { time of delivery. The estimated heat generation rate for Batch } 1 \text { is } 7,820 \\
\text { BTU/hr for Contractor } 1 \text { and } 7,870 \text { BTU/hr for Contractor } 2 \text {. This is well } \\
\text { within the maximum limit of } 70,000 \text { BTU/hr. } \\
\text { The tank characterization report estimated the total heat load in } 241-\text { AN-105 (Jo } \\
\text { 1997) to be } 9,840 \text { W ( } 33,600 \text { BTU/hr total, } 16,800 \text { per Batch). This estimate is } \\
\text { also well below the maximum limit. This estimate is conservative since it does } \\
\text { not take into account the additional decay that will take place before delivery of } \\
\text { the feed Batch. } \\
\text { Conformance with OSD factors achieved. }\end{array}$ & $\begin{array}{l}\text { No further } \\
\text { information is } \\
\text { needed. }\end{array}$ \\
\hline & $\begin{array}{l}\text { Maximum }{ }^{137} \mathrm{Cs} \text { concentration of } \\
5.86 \mathrm{E} 10 \mathrm{~Bq} / \mathrm{liter}(6 \mathrm{Ci} / \mathrm{gal}) \text {. }\end{array}$ & $\begin{array}{l}\text { This limit is equivalent to } 1.59 \mathrm{E} 6 \mu \mathrm{Ci} / \mathrm{L} \text {. The OSD limit of } 5.74 \mathrm{ES} \mu \mathrm{Ci} / \mathrm{L} \text { is } \\
\text { more restrictive. } \\
\text { Using the best basis inventory and reported volume for } 241-\mathrm{AN}-105 \text { from Jo } \\
(1997) \text {, the bulk [137Cs] is calculated to be } 4.7 \mathrm{E} 5 \mu \mathrm{Ci} / \mathrm{L} \text { and }[90 \mathrm{Sr}] \text { is } 7.9 \mathrm{E} 3 \\
\mu \mathrm{Ci} / \mathrm{L} \text {. These are both well below the OSD limits of } 5.74 \mathrm{E} 5 \mu \mathrm{Ci} / \mathrm{L} \text { and } 4.04 \mathrm{E} 5 \\
\mu \mathrm{Ci} / \mathrm{L} \text {, respectively. This is a conservative comparison since the } 50-70 \% \\
\text { dilution has not been accounted for in the above estimates. } \\
\text { Conformance with maximum }{ }^{137} \mathrm{Cs} \text { concentration achieved. }\end{array}$ & $\begin{array}{l}\text { No further } \\
\text { information is } \\
\text { needed. }\end{array}$ \\
\hline
\end{tabular}


Table 1. Base Case Operating Scenario Evaluation. (9 Sheets)

\begin{tabular}{|c|c|c|c|}
\hline Elements $^{a}$ & Requirements ${ }^{\mathrm{b}}$ & Discussion/evaluation & $\begin{array}{l}\text { Information } \\
\text { needs }\end{array}$ \\
\hline $\begin{array}{l}\text { Element } 4 \text { - Part 1: } \\
\text { Envelope Requirements } \\
\text { (continued) }\end{array}$ & $\begin{array}{l}\text { The PHMC assumed minimum } \\
\text { limits to distinguish between } \\
\text { Envelope } A \text { and } C \text { and between } \\
\text { Envelopes } A \text { and } B\end{array}$ & $\begin{array}{l}\text { These discriminators do not apply to Batch } 1 \text { (Envelope A). } \\
\text { No concern about distinguishing between envelopes. }\end{array}$ & $\begin{array}{l}\text { No further } \\
\text { information is } \\
\text { needed. }\end{array}$ \\
\hline \multirow[t]{3}{*}{$\begin{array}{l}\text { Element } 4 \text { - Part 2: } \\
\text { Quantity Requirements }\end{array}$} & $\begin{array}{l}\text { Batch size (mass of sodium) } \\
\text { constraints (from the contracts) z } \\
500 \text { MT Na. }\end{array}$ & $\begin{array}{l}\text { Herting (1997, Table 7-2a) found that } 946 \mathrm{MT} \text { Na are recoverable at } 50 \% \\
\text { dilution ratio and } 1016 \mathrm{MT} \text { Na are recoverable at } 75 \% \text { dilution ratio (the } \\
\text { difference is mainly due to leaving less sodium behind in the interstitial liquid } \\
\text { associated with the settled solids - the sodium concentration is less for the } \\
\text { greater dilution). The recoverable sodium is less than } 120 \% \text { of the minimum } \\
\text { limit and is "flagged" for further evaluation. } \\
\text { Resolution of "flag": (1) if necessary, the PHMC will blend in } \\
\text { additional waste or shim the feed batch to meet the } 500 \mathrm{MT} \text { Na } \\
\text { requirement; (2) The minimum } 500 \mathrm{MT} \text { size for the first batch is not } \\
\text { driven by technical or cost considerations; (3) The PHMC has already } \\
\text { identified this as an issue (PHMC 1997, Issue 19H) and (Kirkbride et al. } \\
\text { 1997, Section 3.1.3). RL is considering the recommendation to reduce } \\
\text { this limit to } 300 \mathrm{MT} \text { Na. (4) The availability of the engineering solution } \\
\text { in number (1) avoids the need for additional tank characterization data. } \\
\text { Na quantity requirements will be resolved administratively or by engineering } \\
\text { solution. }\end{array}$ & $\begin{array}{l}\text { No further } \\
\text { information is } \\
\text { needed. }\end{array}$ \\
\hline & $\begin{array}{l}\text { PHMC targeted batch size range } \\
\text { (from the ICD (PHMC 1997, } \\
\text { Table 3D): } 500-600 \text { MT Na. }\end{array}$ & $\begin{array}{l}\text { Same as above. } \\
\text { Na quantity requirements will be resolved administratively or by engineering } \\
\text { solution. }\end{array}$ & $\begin{array}{l}\text { No further } \\
\text { information is } \\
\text { needed. }\end{array}$ \\
\hline & $\begin{array}{l}\text { PHMC desired batch size (from } \\
\text { Operating Scenario): } 514 \mathrm{MT} \text { Na } \\
\text { (Kirkbride et al. 1997, Table 3.1-5) }\end{array}$ & $\begin{array}{l}\text { Same as above. } \\
\text { Na quantity requirements will be resolved administratively or by engineering } \\
\text { solution. }\end{array}$ & $\begin{array}{l}\text { No further } \\
\text { information is } \\
\text { needed. }\end{array}$ \\
\hline
\end{tabular}


Table 1. Base Case Operating Scenario Evaluation. (9 Sheets)

\begin{tabular}{|c|c|c|c|}
\hline Elements $^{\mathrm{a}}$ & Requirements $^{b}$ & Discussion/evaluation & $\begin{array}{l}\text { Information } \\
\text { needs }\end{array}$ \\
\hline \multirow[t]{4}{*}{$\begin{array}{l}\text { Element } 5 \text { - } \\
\text { Miscellaneous Inputs }\end{array}$} & $\begin{array}{l}\text { Physical form of Tank 241-AN-105 } \\
\text { contents }\end{array}$ & $\begin{array}{l}\text { From Jo (1997): } 241 \text {-AN-105 has a noncontinuous floating crust layer that may } \\
\text { be up to } 30 \mathrm{~cm} \text { (1-ft) thick. The layer is easily penetrated and is composed of } \\
\text { easily dissolvable salts. There is approximately } 6.4 \mathrm{~m}(21 \mathrm{ft}) \text { of supernate } \\
\text { which is compositionally homogenous. There are approximately } 4 \mathrm{~m}(13 \mathrm{ft}) \text { of } \\
\text { settled solids. There is no hard pan. }\end{array}$ & $\begin{array}{l}\text { No further } \\
\text { information is } \\
\text { needed }\end{array}$ \\
\hline & $\begin{array}{l}\text { Heel from prior batch remaining in } \\
\text { staging tanks }\end{array}$ & $\begin{array}{l}\text { This is the first batch. Heels remaining from cleanout of } 241-\mathrm{AP}-102 \text { and }-104 \\
\text { are addressed in Section } 2.1 \text { above. }\end{array}$ & $\begin{array}{l}\text { No further } \\
\text { information is } \\
\text { needed }\end{array}$ \\
\hline & Shimming Batch 1 & No shimming is anticipated. & $\begin{array}{l}\text { No further } \\
\text { information is } \\
\text { needed }\end{array}$ \\
\hline & RL direction & No changes to applicable M\&I ICD requirements have been made to date. & $\begin{array}{l}\text { No further } \\
\text { information is } \\
\text { needed }\end{array}$ \\
\hline
\end{tabular}

a. Elements are taken from the Decision Rule statement in Section 6.1 of PSDQO-01.

b. Requirements are taken from Sections 4.1, 4.2, 4.3, 4.4, and 4.5 of PSDQO-01. 
Table 2. Alternative Case Operating Scenario Evaluation. (7 Sheets)

\begin{tabular}{|c|c|c|c|}
\hline Elements ${ }^{\mathrm{a}}$ & Requirements ${ }^{b}$ & Discussion/evaluation & Information needs \\
\hline \multirow[t]{2}{*}{$\begin{array}{l}\text { Element 1, Dilution } \\
\text { Ratio and Diluent } \\
\text { Composition }\end{array}$} & \multirow[t]{2}{*}{$\begin{array}{l}\text { Determine the desired dilution } \\
\text { ratio and diluent composition for } \\
\text { each waste transfer. }\end{array}$} & $\begin{array}{l}\text { (a) As applied to supernate composite: } \\
\text { This information was not obtained and is still needed. }\end{array}$ & $\begin{array}{l}\text { Desired dilution } \\
\text { ratio and diluent } \\
\text { composition for a } \\
\text { representative } \\
\text { sample of } \\
\text { supernate (See } \\
\text { Table 3, Item \# 2) }\end{array}$ \\
\hline & & $\begin{array}{l}\text { (b) As applied to salt slurry composite: A process test was performed (Herting } \\
\text { 1997a). The test was conducted in accordance with a test plan (Herting } \\
\text { 1997b). The test plan was based on instruction provided by the Disposal } \\
\text { Program (Garfield 1997). The settled solids composite results of this test } \\
\text { determined that the required dilution ratio }{ }^{1} \text { is } 80-120 \% \text { and that the desired } \\
\text { diluent is water. } \\
\text { Dilution and Diluent Composition established. }\end{array}$ & $\begin{array}{l}\text { No further } \\
\text { information is } \\
\text { needed. }\end{array}$ \\
\hline \multirow[t]{2}{*}{$\begin{array}{l}\text { Element 2, Transfer } \\
\text { Requirements are } \\
\text { Satisfied }\end{array}$} & \multirow{2}{*}{$\begin{array}{l}\text { Confirm that the as-retrieved } \\
\text { waste (including dilution water } \\
\text { or caustic) remains below } \\
\text { saturation in major Na salts } \\
\text { during the transfer to the staging } \\
\text { tank. }\end{array}$} & $\begin{array}{l}\text { (a) As applied to supernate composite with proper amount of diluent added: } \\
\text { This information was not obtained and is still needed. }\end{array}$ & $\begin{array}{l}\text { See requirement } \\
\text { (See Table 3, Item } \\
\text { \# 3). }\end{array}$ \\
\hline & & $\begin{array}{l}\text { (b) As applied to salt slurry composite with proper amount of diluent added: } \\
\text { Analysis of data in Herting (1997a, Section 5.3) found that beyond a dilution } \\
\text { ration of } 80 \% \text { for the settled solids the supernate is below saturation in major } \\
\text { Na salts. } \\
\text { Below saturation established. }\end{array}$ & $\begin{array}{l}\text { No further } \\
\text { information is } \\
\text { needed. }\end{array}$ \\
\hline
\end{tabular}

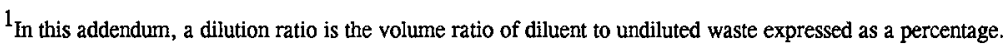


Table 2. Alternative Case Operating Scenario Evaluation. (7 Sheets)

\begin{tabular}{|c|c|c|c|}
\hline Elements $^{a}$ & Requirements ${ }^{\mathbf{b}}$ & Discussion/evaluation & Information needs \\
\hline \multirow[t]{3}{*}{$\begin{array}{l}\text { Element 2, Transfer } \\
\text { Requirements are } \\
\text { Satisfied (continued) }\end{array}$} & \multirow[t]{2}{*}{$\begin{array}{l}\text { Confirm that the as-retrieved } \\
\text { waste (including dilution water } \\
\text { or caustic) remain at or below } \\
\text { viscosity of } 10 \mathrm{cP} \text {, at or below a } \\
1.5 \mathrm{SpG} \text {, and at or below } 30 \\
\text { percent solids by volume during } \\
\text { the transfer to the staging tank. }\end{array}$} & $\begin{array}{l}\text { (a) As applied to supernate composite with proper amount of diluent added: } \\
\text { This information was not obtained and is still needed. }\end{array}$ & $\begin{array}{l}\text { See requirement } \\
\text { (See Table } 3 \text {, } \\
\text { Item \# 4). }\end{array}$ \\
\hline & & $\begin{array}{l}\text { (b) As applied to salt slurry composite with proper amount of diluent added: } \\
\text { Herting (1997a, Section } 3.3 .1 \text { ) found that the viscosity of the settled solids at } \\
\text { a } 80 \% \text { dilution ratio over the temperature range of } 28 \text { to } 65{ }^{\circ} \mathrm{C} \text { varies from } 2.5 \\
\text { to } 7.0 \mathrm{cP} \text {. All samples exhibited Newtonian behavior. Continued dilution to } \\
120 \% \text { is expected to further reduce the viscosity since no additional solids } \\
\text { were observed to precipitate. } \\
\text { The observed quantity of settled solids that Herting ( } 1997 \mathrm{a} \text {, Table } 4-6) \\
\text { observed for the settled solids dilutions of } 80 \% \text { at temperatures of } 25,45 \text { and } \\
65{ }^{\circ} \mathrm{C} \text { at } 20 \text { hours after mixing ranged from } 16-27 \text { volume } \% \text {; at } 120 \% \\
\text { dilution they ranged from } 12-18 \text { volume } \% \text {. } \\
\text { Herting ( } 1997 \mathrm{a}, \text { Section } 3.1 \text { ) found that the liquid phase density for salt slurry } \\
\text { dilutions of } 80 \% \text { and } 120 \% \text { performed at temperatures of } 25,45 \text { and } 65{ }^{\circ} \mathrm{C} \\
\text { ranged from } 1.24 \text { to } 1.49 \mathrm{~g} / \mathrm{ml} \text {. Bulk densities calculated from the raw data in } \\
\text { this section range from } 1.24 \text { to } 1.38 \mathrm{~g} / \mathrm{ml} \text {. These values are less than the limit } \\
\text { by more than } 0.05 \mathrm{~g} / \mathrm{ml} \text {. Correction for reference conditions for SpG are not } \\
\text { important. } \\
\text { Viscosity, SpG, suspended solids no concern. }\end{array}$ & $\begin{array}{l}\text { No further } \\
\text { information is } \\
\text { needed. }\end{array}$ \\
\hline & $\begin{array}{l}\text { Confirm that the dilution ratio, } \\
\text { diluent composition, and waste } \\
\text { composition are balanced so } \\
\text { gibbsite or high viscosity } \\
\text { slurries do not precipitate. }\end{array}$ & $\begin{array}{l}\text { Herting ( } 1997 \mathrm{a}, \text { Section } 2.2) \text { did not observe precipitation during extended } \\
\text { storage ( } 4-8 \text { weeks) of supernate sub-samples from the WTC dilution tests at } \\
0,25,50 \text { and } 75 \% \text { dilution at temperatures of } 25,45 \text { and } 65^{\circ} \mathrm{C} \text {. This covers } \\
\text { all practical dilution ratios. } \\
\text { Special Consideration: If gibbsite will form, it should form within four weeks. } \\
\text { Samples were observed for } 4-8 \text { weeks. } \\
\text { No precipitation concern. }\end{array}$ & $\begin{array}{l}\text { No further } \\
\text { information is } \\
\text { needed. }\end{array}$ \\
\hline
\end{tabular}


Table 2. Alternative Case Operating Scenario Evaluation. (7 Sheets)

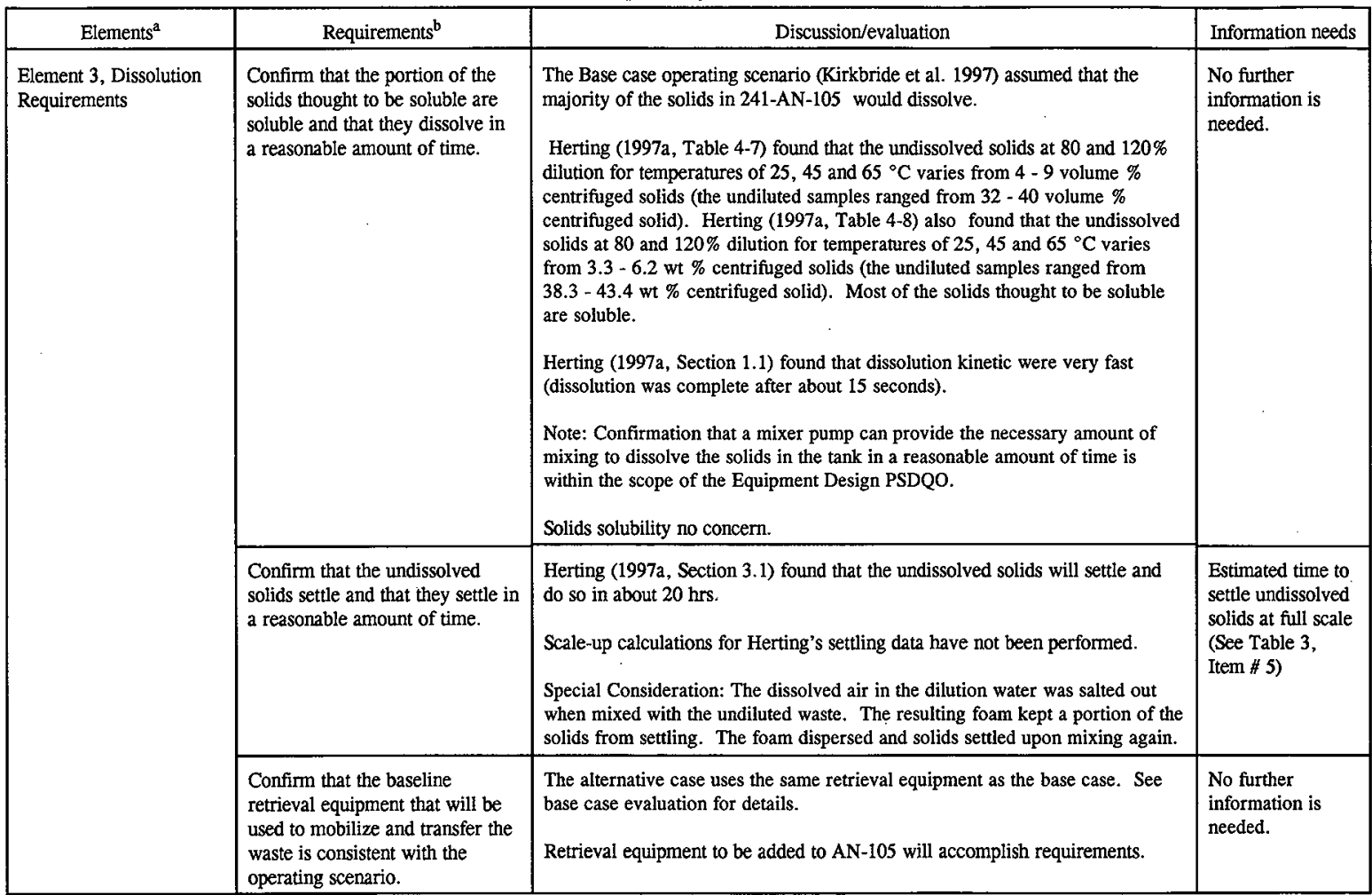


Table 2. Alternative Case Operating Scenario Evaluation. (7 Sheets)

\begin{tabular}{|c|c|c|c|}
\hline Elements $^{a}$ & Requirements ${ }^{\mathrm{b}}$ & Discussion/evaluation & Information needs \\
\hline \multirow[t]{2}{*}{$\begin{array}{l}\text { Element } 4 \text { - Part 1: } \\
\text { Envelope Requirements } \\
\text { These limits apply to the } \\
\text { feed actually delivered to } \\
\text { the private contractors. }\end{array}$} & $\begin{array}{l}\text { Concentration limits for the } \\
\text { chemical and radionuclide } \\
\text { content of the feed (DOE-RL } \\
\text { 1996, Section C.6). } \\
\text { See Section 2.0, Tables } 1 \text { and } 2 \\
\text { (in main report) for the limits. }\end{array}$ & $\begin{array}{l}\text { Only Envelope A limits apply to Batch } 1 \text {. } \\
\text { In the alternative case, the composition of the waste staged in } 241-A P-102 \text { and } \\
-104 \text { is almost identical to that of the base case. There will be differences in } \\
\text { absolute concentration due to differences in the total amount of dilution, but } \\
\text { this will not affect the [analyte]:[Na] values. There will also be differences } \\
\text { due to slightly different extent of solids dissolution, but these are bounded by } \\
\text { the evaluation for the Base Case that was based on the Welsh (1997) report. } \\
\text { Herting (1997a, Section 1.0) found that "under all dilution conditions studied, } \\
\text { the retrievable waste fell within the feed specification limits established for } \\
\text { Envelope A in the Phase I Privatization contracts". } \\
\text { Compliance with Envelope A achieved. }\end{array}$ & $\begin{array}{l}\text { No further } \\
\text { information is } \\
\text { needed. }\end{array}$ \\
\hline & $\begin{array}{l}\text { Concentration limit for the } \\
\text { sodium concentration of the feed: } \\
3 \mathrm{M} \leq[\mathrm{Na}] \leq 14 \mathrm{M} \text { (DOE-RL } \\
1996 \text {, Section C.6). }\end{array}$ & $\begin{array}{l}\text { Since the supernate dilution ratio was not established, the resulting [Na] in the } \\
\text { Batch can not be directly determined. However, a bounding calculation shows } \\
\text { that the lower limit will be satisfied: Assume that the dilution ratio required } \\
\text { by the supernate layer will be equal to the dilution ratio required by the salt } \\
\text { slurry layer. The lowest ( } 95 \% \mathrm{Cl} \text { around the mean for the various statistical } \\
\text { models and analytical methods employed) estimate of the bulk [Na] was } 10.2 \\
\mathrm{M} \text { (Welsh } 1997 \text {, Section } 7 \text { ). The lowest [Na] in the feed batch is the } \\
\text { [Na]bulk } /(1+120 \% / 100 \%) \text { to account for } 120 \% \text { dilution). This yields a value } \\
\text { of } 4.6 \mathrm{M} \text {. } \\
\text { Another bounding calculation shows that the upper limit will be satisfied: } \\
\text { Assume that no dilution is required by the supernate layer. The overall } \\
\text { dilution ratio will not exceed } 100 \%\{1-[(.6)+(.4) *(1+80 \% / 100 \%)]\}=32 \% \text {; } \\
\text { The largest ( } 95 \% \text { CI around the mean for the various statistical models and } \\
\text { analytical methods employed) estimate of the bulk [Na] was } 15.2 \mathrm{M} \text { (Welsh } \\
\text { 1997, Section } 7 \text { ). Dilution of waste with a } 15.2 \mathrm{M}[\mathrm{Na}] \text { at a } 32 \% \text { dilution ratio } \\
\text { yields a [Na] of } 11.5 \text { which is well within the upper limit. } \\
\text { In any case, the sodium concentration for the feed batch can be adjusted in the } \\
\text { intermediate feed staging tanks. } \\
\text { Compliance with Na molarity achieved. }\end{array}$ & $\begin{array}{l}\text { No further } \\
\text { information is } \\
\text { needed. }\end{array}$ \\
\hline
\end{tabular}


Table 2. Alternative Case Operating Scenario Evaluation. (7 Sheets)

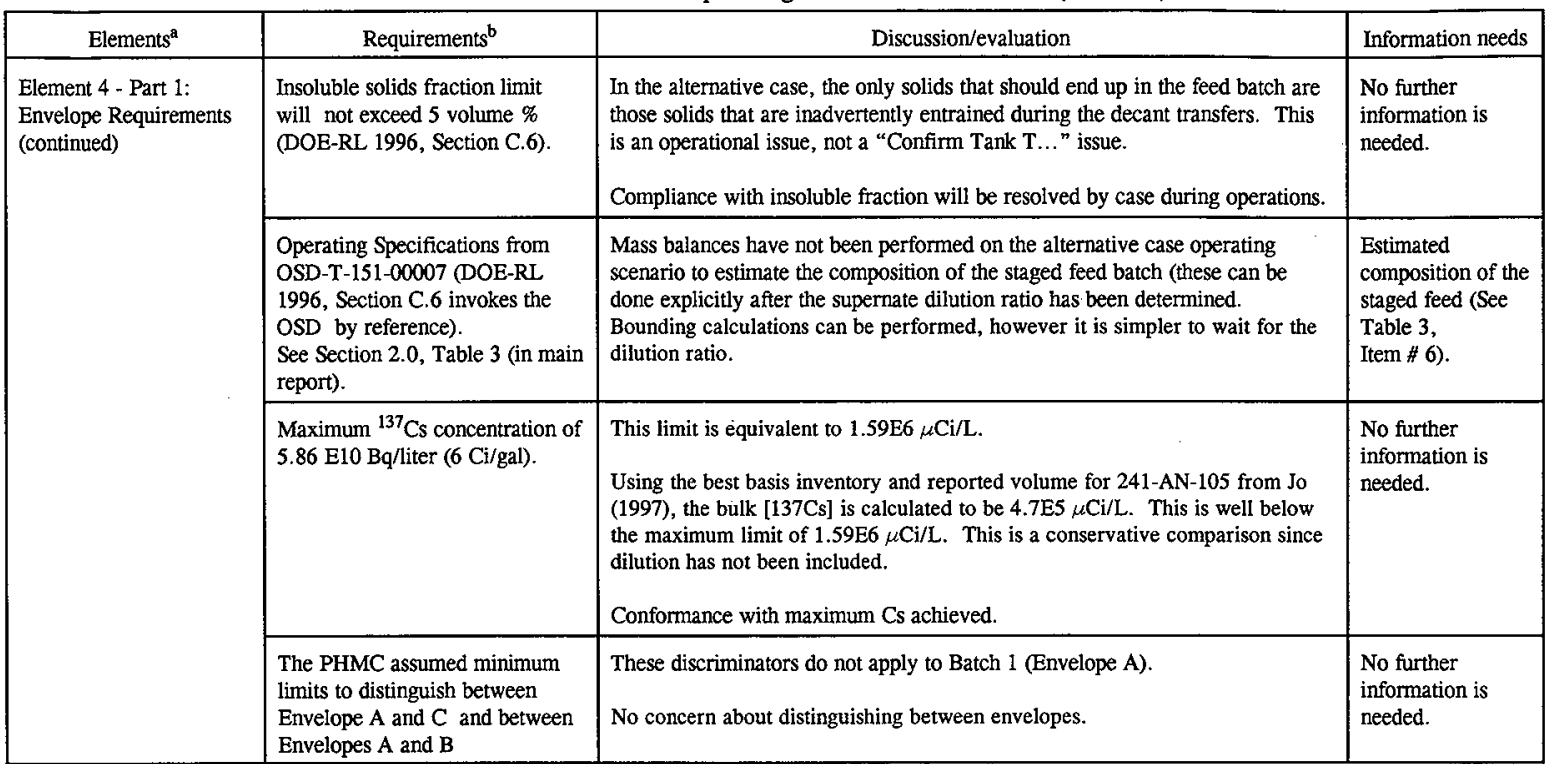


Table 2. Alternative Case Operating Scenario Evaluation. (7 Sheets)

\begin{tabular}{|c|c|c|c|}
\hline Elements $^{a}$ & Requirements $^{b}$ & Discussion/evaluation & Information needs \\
\hline \multirow[t]{3}{*}{$\begin{array}{l}\text { Element } 4 \text { - Part } 2: \\
\text { Quantity Requirements } \\
\text { are Satisfied }\end{array}$} & $\begin{array}{l}\text { Batch size (mass of sodium) } \\
\text { constraints (from the contracts) } 2 \\
500 \text { MT Na. }\end{array}$ & $\begin{array}{l}\text { Herting (1997, Table 7-2b) found that } 973 \mathrm{MT} \text { Na are recoverable at } 80 \% \\
\text { dilution ratio and 1011 MT Na are recoverable at } 120 \% \text { dilution ratio (the } \\
\text { difference is mainly due the leaving less sodium behind in the interstitial liquid } \\
\text { associated with the settled solids - the sodium concentration is less for the } \\
\text { greater dilution). The recoverable sodium is less than } 120 \% \text { of the minimum } \\
\text { limit and is "flagged" for further evaluation. } \\
\text { Resolution of "flag": (1) if necessary, the PHMC will blend in } \\
\text { additional waste or shim the feed batch to meet the } 500 \mathrm{MT} \text { Na } \\
\text { requirement; (2) The minimum } 500 \mathrm{MT} \text { size for the first batch is not } \\
\text { driven by technical or cost considerations; (3) The PHMC has already } \\
\text { identified this as an issue (PHMC 1997, Issue 19H) and (Kirkbride et } \\
\text { al. } 1997 \text {, Section 3.1.3). RL is considering the recommendation to } \\
\text { reduce this limit to } 300 \text { MT Na. (4) The availability of the engineering } \\
\text { solution in number (1) avoids the need for additional tank } \\
\text { characterization data. } \\
\text { Na quantity requirements will be resolved administratively or by shimming. }\end{array}$ & $\begin{array}{l}\text { No further } \\
\text { information is } \\
\text { needed. }\end{array}$ \\
\hline & $\begin{array}{l}\text { PHMC targeted batch size range } \\
\text { (from the ICD (PHMC 1997, } \\
\text { Table 3D): } 500-600 \text { MT Na. }\end{array}$ & $\begin{array}{l}\text { Same as above. } \\
\text { Na quantity requirements will be resolved administratively or by shimming. }\end{array}$ & $\begin{array}{l}\text { No further } \\
\text { information is } \\
\text { needed. }\end{array}$ \\
\hline & $\begin{array}{l}\text { PHMC desired batch size (from } \\
\text { Operating Scenario): } 514 \mathrm{MT} \mathrm{Na} \\
\text { (Kirkbride et al. 1997, Table } \\
\text { 3.1-5) }\end{array}$ & $\begin{array}{l}\text { Same as above. } \\
\text { Na quantity requirements will be resolved administratively or by shimming. }\end{array}$ & $\begin{array}{l}\text { No further } \\
\text { information is } \\
\text { needed. }\end{array}$ \\
\hline \multirow[t]{2}{*}{$\begin{array}{l}\text { Element } 5 \text { - } \\
\text { Miscellaneous Inputs }\end{array}$} & $\begin{array}{l}\text { Physical form of Tank } \\
241-A N-105 \text { contents }\end{array}$ & $\begin{array}{l}241-\mathrm{AN}-105 \text { has a } 30-\mathrm{cm} \text { (1-ft) crust that is easily penetrated and is composed } \\
\text { of easily dissolvable salts. There is } 19.3 \mathrm{ft} \text { of supernate that is compositionally } \\
\text { homogenous. There is } 14.8 \mathrm{ft} \text { of settled solids. There is no hard pan. }\end{array}$ & $\begin{array}{l}\text { No further } \\
\text { information is } \\
\text { needed }\end{array}$ \\
\hline & $\begin{array}{l}\text { Heel from prior batch remaining } \\
\text { in staging tanks }\end{array}$ & $\begin{array}{l}\text { This is the first batch. Heels remaining from cleanout of } 241-\mathrm{AP}-102 \text { and -104 } \\
\text { are addressed in Section } 2.1 \text { above. }\end{array}$ & $\begin{array}{l}\text { No further } \\
\text { information is } \\
\text { needed }\end{array}$ \\
\hline
\end{tabular}


Table 2. Alternative Case Operating Scenario Evaluation. (7 Sheets)

\begin{tabular}{|l|l|l|l|}
\hline \multicolumn{1}{|c|}{ Elements $^{\mathrm{a}}$} & \multicolumn{1}{|c|}{ Requirements $^{\mathrm{b}}$} & \multicolumn{1}{c|}{ Discussion/evaluation } & Information needs \\
\hline $\begin{array}{l}\text { Element 5 - } \\
\begin{array}{l}\text { Miscellaneous Inputs } \\
\text { (continued) }\end{array}\end{array}$ & Shimming Batch 1 & No shimming is anticipated. & $\begin{array}{l}\text { No further } \\
\text { information is } \\
\text { needed }\end{array}$ \\
\cline { 2 - 5 } & RL direction & No changes to applicable M\&I ICD requirements have been made to date. & $\begin{array}{l}\text { No further } \\
\text { information is } \\
\text { needed }\end{array}$ \\
\hline
\end{tabular}

${ }^{\mathrm{a}}$ Elements are taken from the Decision Rule statement in Section 6.1 of PSDQO-01.

${ }^{b}$ Requirements are taken from Sections $4.1,4.2,4.3,4.4$, and 4.5 of PSDQO-01. 
Table 3 was developed jointly by TWRS Characterization and Tank Waste Retrieval. It is intended to show what information is still needed, what can be obtained by calculations with existing data, what requires new (or existing) samples, analysis and/or process testing. Where samples are required, the amount and "representativeness" of the sample will be stated.

Where analysis is needed, the specific analytes and QA requirements will be stated. If process testing is needed, the amount of sample and goals of the process test will be stated.

Appropriate level of end description of QA requirements will be covered in the specific work plan for these limited process tests.

Table 3. Information Needs.

\begin{tabular}{|l|l|l|l|}
\hline Item & \multicolumn{1}{|c|}{ Information need } & \multicolumn{1}{|c|}{ Planned resolution } & \multicolumn{1}{|c|}{$\begin{array}{l}\text { Sample } \\
\text { required }\end{array}$} \\
\hline 1 & $\begin{array}{l}\text { Estimate time to settle } \\
\text { undissolved solids at full } \\
\text { scale }\end{array}$ & $\begin{array}{l}\text { Engineering calculations: no additional } \\
\text { tests required }\end{array}$ & None \\
\hline 2 & $\begin{array}{l}\text { Desired dilution ratio } \\
\text { and diluent composition } \\
\text { for a representative } \\
\text { sample of supernate. }\end{array}$ & $\begin{array}{l}\text { Calculate from results of Item \#3 and ESP. } \\
\text { No additional tests required. }\end{array}$ & None \\
\hline 3 & $\begin{array}{l}\text { Confirm as-retrieved } \\
\text { waste remains below satn } \\
\text { in major NA salts during } \\
\text { transfer. }\end{array}$ & $\begin{array}{l}\text { Perform lab test: measure \% solids vs. } \\
\text { temp for supernate at } 25 \text { and } 65 \text { degrees C } \\
\text { under 4 conditions: (1\&2) increasing } \\
\text { temp. undiluted and diluted 15\%, (3\&4) } \\
\text { decreasing temp. undiluted and diluted } \\
15 \% .\end{array}$ & $\begin{array}{l}10 \mathrm{~g}^{1} \\
\text { solids and } \\
60 \mathrm{~mL} \\
\text { supernate }\end{array}$ \\
\hline 4 & $\begin{array}{l}\text { Confirm as-retrieved } \\
\text { waste remains }<10 \mathrm{cP}, \\
<1.5 \text { SpG, and }<30 \% \\
\text { solids during transfer. }\end{array}$ & $\begin{array}{l}\text { SpG and \%Solids already known. } \\
\text { Measure viscosity of undiluted supernate at } \\
25 \text { to } 65 \text { C, which should be <10 cP. All } \\
\text { dilutions will be lower. }\end{array}$ & $\begin{array}{l}5 \mathrm{~g} \text { solids } \\
\text { and } 20 \mathrm{~mL} \\
\text { supernate }\end{array}$ \\
\hline 5 & See item \#1. & See item \#1. & None \\
\hline 6 & $\begin{array}{l}\text { Estimate composition of } \\
\text { staged feed. }\end{array}$ & $\begin{array}{l}\text { Can be calculated from existing data after } \\
\text { item \#2 is resolved. }\end{array}$ & None \\
\hline
\end{tabular}

${ }^{1}$ The solids are needed to re-establish the original solid-liquid equilibria that was present in 241-AN-105.

There are six items that have been flagged in Tables 1 and 2 requiring further information. All involve performing a specific process test with specific material from 241-AN-105. There are no other information needs requiring either an analysis of an existing 241-AN-105 sample or the collection of additional sample followed by analysis in order to confirm that tank 241-AN-105 is appropriate for Batch 1. 
HNF-2799

Revision 0

\subsection{REFERENCES}

Boston, H. L., 1997, Subcontract Number 80232764-9-K001, Design Basis for Retrieval Equipment in Tanks $A N-104$ and $A N-105$, Letter to A. M. Umek (Fluor Daniel Hanford, Incorporated), LMHC-9758071, Lockheed Martin Hanford Corporation, Richland, Washington.

Certa, P. J., W. H. Grams, C. M. McConville, L. W. Shelton and E. J. Slaathaug, 1996, Low-Level Waste Feed Staging Plan, WHC-SD-WM-RPT-224, Rev. 0, Westinghouse Hanford Company, Richland, Washington.

DOE-RL, 1996, TWRS Privatization, Contract Numbers DE-RP06-96RL13308 and 13309, U.S. Department of Energy, Richland, Washington.

Garfield, J. S., 1997, Tank 241-AN-105 Dilution/Dissolution Test Requirements, internal memo to DL Herting, 8C451-97-004 (March 27), Numatec Hanford Corporation, Richland, Washington.

Herting, D. L., 1997a, Results of Dilution Studies with Waste from Tank 241-AN-105, HNF-SD-WM-DTR-046, Rev. 0, Numatec Hanford Corporation, Richland, Washington.

Herting, D. L, 1997b, Test Plan for Tank 241-AN-105 Dilution Studies, HNF-SD-WM-ER-678, Rev. 0B, Lockheed Martin Hanford Corporation, Richland, Washington.

Jo, J., 1997, Tank Characterization Report for Double-Shell Tank 241-AN-105, HNF-SD-WM-ER-678, Rev. 0A, Lockheed Martin Hanford Company, Richland, Washington.

Kirkbride, R. A., G. K. Allen, P. J. Certa, A. F. Manuel, R. M. Orme, L. W. Shelton, E. J. Slaathaug, R. S. Wittman, G. T. MacLean and D. L. Penwell, 1997, Tank Waste Remediation System Operation and Utilization Plan, HNF-SD-WM-SP-012, Rev. 0A, Vol. I and II, Numatec Hanford Corporation, Richland, Washington.

PHMC, 1996, Unclassified Operating Specification for the 241-AN, AP, AW, AY, AZ, and SY Tank Farms, OSD-T-151-00007, Rev. H-18, Fluor Daniel Hanford, Richland, Washington.

PHMC, 1997, Interface Control Document Between DOE and the PHMC, Low-Activity Waste Feed, HNF-SP-1223 (ICD-19), Project Hanford Management Contractor, Richland, Washington. 
HNF-2799

Revision 0

Welsh, T. L. (1997), Waste Envelope "A" Comparison, 241-AN-105, HNF-SD-WM-TI-813, Rev. 0 (11/27/97 draft), B\&W Protec, Inc., Richland, Washington. 


\section{ADDENDUM 2}

\section{APPLICATION OF}

\section{"CONFIRM TANK T IS AN APPROPRIATE FEED SOURCE FOR LOW-ACTIVITY WASTE FEED BATCH $X "$}

TO

241-AN-104 / BATCH 2 
HNF-2799

Revision 0

This page intentionally left blank.

Addendum 2-2 
HNF-2799

Revision 0

CONTENTS

1.0 INTRODUCTION $\ldots \ldots \ldots \ldots \ldots \ldots \ldots \ldots \ldots \ldots$ Addendum $2-5$

2.0 EVAlUATION $\ldots \ldots \ldots \ldots \ldots \ldots \ldots \ldots \ldots$ Addendum $2-7$

2.1 BASE CASE OPERATING SCENARIO $\ldots \ldots \ldots \ldots \ldots$ Addendum $2-7$

2.2 ALTERNATIVE CASE OPERATING SCENARIO $\ldots \ldots \ldots$ Addendum $2-8$

3.0 REFERENCES $\ldots \ldots \ldots \ldots \ldots \ldots \ldots \ldots \ldots \ldots$. . . . . . . . . . . . . . . . $2-22$

\section{LIST OF TABLES}

1. Base Case Operating Scenario Evaluation $\ldots \ldots \ldots \ldots \ldots$ Addendum 2-10

2. Alternative Case Operating Scenario Evaluation. . . . . . . Addendum 2-16

3. Information Needs. $\ldots \ldots \ldots \ldots \ldots \ldots \ldots \ldots \ldots$ Addendum $2-20$ 
HNF-2799

Revision 0

\section{LIST OF TERMS}

DOE U.S. Department of Energy

ICD Interface Control Document

LAW Low-Activity Waste

M Molar (gmoles/liter)

PHMC Project Hanford Management Contract(or)

PMBS Project Master Baseline Schedule

PSDQO Problem-Specific Data Quality Objectives

RL U.S. Department of Energy-Richland Operations

TANK T Refers to the contents from one tank, multiple tanks, or portions of one or more tanks that will be used to prepare a feed batch

TOC Total Organic Carbon

TWRS Tank Waste Remediation System

TWRSO\&UP Tank Waste Remediation System Operation and Utilization Plan

USQ Unreviewed Safety Question

WIT Waste Disposal Integration Team

WTC Whole tank composite 
HNF-2799

Revision 0

\section{APPLICATION OF "CONFIRM TANK T IS AN APPROPRIATE FEED SOURCE FOR LOW-ACTIVITY WASTE FEED BATCH X" TO 241-AN-104 / BATCH 2}

\subsection{INTRODUCTION}

This addendum applies Revision 1 of "Confirm Tank $\mathrm{T}$ is an Appropriate Feed Source for Low-Activity Waste Feed Batch X" problem-specific data quality objectives (PSDQO) to tank 241-AN-104 / Batch 2.

This application of the DQO is divided into a Base Case Operating Scenario and an Alternative Case Operating Scenario. The Base Case homogenizes the waste in tank 241-AN-104 by mixing prior to transfer to 241-AP-102 and -104. The Alternative Case transfers the tank 241-AN-104 supernate to 241-AP-102 and -104 without mixing followed by subsequent diluent addition and mixing in 241-AN-104 before transfer to 241-AP-102 and -104 . 
HNF-2799

Revision 0

This page intentionally left blank.

Addendum 2-6 
HNF-2799

Revision 0

\subsection{EVALUATION}

\subsection{BASE CASE OPERATING SCENARIO}

Translate the operating scenario into a series of process steps.

The base case operating scenario from the Tank Waste Remediation System Operation and Utilization Plan (TWRSO\&UP) (Kirkbride et al. 1997) includes the following steps to make up Batch 2:

- Empty 241-AP-102 and -104 (the feed staging tanks) leaving a 0.1 ML (10-in.) heel behind in each tank.

- Homogenize the waste in 241-AN-104 using mixer pumps to resuspend the salt slurry.

- Transfer half of the homogenized waste in 241-AN-104 to 241-AP-102 and the remaining half to 241-AP-104, leaving a $0.1 \mathrm{ML}$ (10-in.) heel. During the transfer, the proper amount of diluent will be added to the waste at the transfer pump inlet.

- Mix the waste in 241-AP-102 and mix the waste in 241-AP-104.

- Allow undissolved solids to settle.

The heel in 241-AP-102 and -104 can be neglected for the purposes of this PSDQO; The waste compositions of tank $241-\mathrm{AN}-105$ and tank $241-\mathrm{AN}-104$ are very similar.

Define the waste that applies to each element in the decision rule.

Element 1, Dilution Ratio and Diluent Composition: this applies to the whole tank composite (WTC) of 241-AN-104 over the temperature of $45^{\circ} \mathrm{C}$.

Element 2, Transfer Requirements: there are two nearly identical transfers; they will be treated as one transfer. Transfer requirements apply to a whole tank composite of the waste currently in 241-AN-104 after addition of the proper amount of diluent over the temperature range of 25 to $65^{\circ} \mathrm{C}$.

Element 3, Mixing Requirements: the mixing requirement applies to a salt slurry composite of the waste currently in 241 -AN-104 over the temperature of $45^{\circ} \mathrm{C}$.

Element 4, Envelope Requirements: there is one unique Batch 2 composition; the composition and physical properties are that of a whole tank composite of the waste currently in 241-AN-104 after addition of the proper amount of diluent over the temperature of $45^{\circ} \mathrm{C}$. 
HNF-2799

Revision 0

The heel in 241-AP-102 and -104 can be neglected for the purposes of this PSDQO (all current data strongly indicate that the 241-AP-102 and -104 heel will not interfere with staging the compositionally correct feed).

Element 5, Miscellaneous Inputs: These inputs apply to the whole tank composition of 241-AN-104 or to changes in the operating scenario that may be imposed in the future.

Evaluate existing data and determine information needs.

Table 1 contains the evaluation of the base case operating scenario for all the elements of the decision rules found in Section 6 of the PSDQO. The table lists each element taken from Section 4.0 of the PSDQO. For each element, the requirements specific to 241-AN-104/ Batch 2 are listed. Each requirement is evaluated against existing data and the remaining information needs are identified. The information needs are summarized in Table 3.

\subsection{ALTERNATIVE CASE OPERATING SCENARIO}

Translate the operating scenario into a series of process steps.

The TWRSO\&UP (Kirkbride et al. 1997) recommended that process control issues be taken into account. This alternative case operating scenario was developed based on consideration of process control issues and is currently being evaluated and incorporated into the project master baseline schedule and corresponding logic diagrams. The steps that directly affect the composition of Batch 2 are listed below:

- Empty 241-AP-102 and -104 (the feed staging tanks) leaving a 0.1 ML (10-in.) heel behind in each tank.

- Decant the supernate in 241-AN-104; transfer half of the supernate to 241-AP-102 and the remainder to 241 -AP-104, leaving a 10 -in. heel above the salt slurry. During these transfers diluent will be added to the waste at the pump inlet.

- Add diluent to the salt slurry in 241-AN-104 and mix.

- Allow undissolved solids to settle in 241-AN-104.

- Transfer half of the liquid in 241-AN-104 to 241-AP-102 and the remaining to 241-AP-104, leaving a 10-in. heel. No additional diluent is expected to be needed for the transfer.

- Mix the waste in 241-AP-102 and mix the waste in 241-AP-104.

- Allow any undissolved solids that were inadvertently entrained to settle in 241-AP-102 and -104. 
HNF-2799

Revision 0

The heel in 241-AP-102 and -104 can be neglected for the purposes of this PSDQO; The waste compositions of tank 241-AN-105 and tank 241-AN-104 are very similar.

Define the waste that applies to each element in the decision rule.

Element 1, Dilution Ratio and Diluent Composition: this applies to (a) a supernate composite from 241-AN-104 and (b) a salt slurry composite from 241-AN-104, both over the temperature range of 25 to $65^{\circ} \mathrm{C}$.

Element 2, Transfer Requirements: out of four transfers, there are two distinct transfers. The transfer requirements applies to (a) supernate composite from 241-AN-104 after addition of the proper amount of diluent and (b) a salt slurry composite from 241-AN-104 after addition of the proper amount of diluent and settling of undissolved solids over the temperature range of 25 to $65^{\circ} \mathrm{C}$.

Element 3, Dissolution Requirements: the dissolution requirements applies to the whole tank composite of the waste currently in 241-AN-104 over the temperature range of 25 to $65{ }^{\circ} \mathrm{C}$.

Element 4, Envelope Requirements: there is one unique Batch 2 composition; the composition and physical properties are that of a whole tank composite of the waste currently in 241-AN-104 after addition of the proper amount of diluent over the temperature range of 25 to $65{ }^{\circ} \mathrm{C}$. The heel in 241-AP-102 and -104 can be neglected for the purposes of this PSDQO (all current data strongly indicate that 241-AP-102 and -104 heel will not interfere with staging the compositionally correct feed).

Element 5, Miscellaneous Inputs: these inputs apply to the whole tank composition of 241-AN-104 or to changes in the operating scenario that may be imposed in the future.

\section{Evaluate existing data and determine information needs.}

Table 2 contains the evaluation of the alternative case operating scenario for all the elements of the decision rule found in Section 6.0 of the PSDQO for Confirm Tank T. The table lists each element of the decision rule taken from Section 4.0 of the PSDQO. For each element, the requirements specific to 241-AN-104 / Batch 2 are listed. Each requirement is evaluated against existing data and remaining information needs are identified. The information needs are developed more fully in Table 3. 
Table 1. Base Case Operating Scenario Evaluation. (6 Sheets)

\begin{tabular}{|c|c|c|c|}
\hline Elements $^{\mathrm{a}}$ & Requirements ${ }^{\mathfrak{b}}$ & Discussion/evaluation & Information needs \\
\hline $\begin{array}{l}\text { Element } 1 \text {, Dilution } \\
\text { Ratio and Diluent } \\
\text { Composition }\end{array}$ & $\begin{array}{l}\text { Determine the desired dilution ratio } \\
\text { and diluent composition for each } \\
\text { waste transfer. }\end{array}$ & $\begin{array}{l}\text { A process test is being performed in accordance with a test plan } \\
\text { (Herting 1998). The test plan is based on instruction provided by } \\
\text { the Disposal Program (Garfield 1997). The whole tank composite } \\
\text { (WTC) results of this test apply to the Base case operating scenario. } \\
\text { Dilution ratio and Diluent composition will be established. }\end{array}$ & $\begin{array}{l}\text { Desired dilution ratio } \\
\text { and diluent } \\
\text { composition (See } \\
\text { Table 3, Item \# } 1 \text { ). }\end{array}$ \\
\hline \multirow[t]{3}{*}{$\begin{array}{l}\text { Element } 2 \text {, Transfer } \\
\text { Requirements }\end{array}$} & $\begin{array}{l}\text { Confirm that the as-retrieved waste } \\
\text { (including dilution water or caustic) } \\
\text { remains below saturation in major } \\
\text { Na salts during the transfer to the } \\
\text { staging tank. }\end{array}$ & $\begin{array}{l}\text { A process test is being performed in accordance with a test plan } \\
\text { The test is being performed for WTC and WTC with dilution ratio } \\
\text { of } 50 \% \text { (Herting 1998). }\end{array}$ & $\begin{array}{l}\text { Confirm a dilution } \\
\text { ratio of } 50 \% \text { for the } \\
\text { WTC is below } \\
\text { saturation in major } \\
\text { Na salts (See Table 3, } \\
\text { Item \# 2). }\end{array}$ \\
\hline & $\begin{array}{l}\text { Confirm that the as-retrieved waste } \\
\text { (including dilution water or caustic) } \\
\text { remain at or below viscosity of } \\
10 \mathrm{cP} \text {, at or below a } 1.5 \mathrm{SpG} \text {, and at } \\
\text { or below } 30 \text { percent solids by } \\
\text { volume during the transfer to the } \\
\text { staging tank. }\end{array}$ & $\begin{array}{l}\text { A process test is being performed in accordance with a test plan } \\
\text { (Herting 1998). The test will determine viscosity of the undiluted } \\
\text { WTC, undiluted supernate from WTC, and at a } 50 \% \text { dilution ratio } \\
\text { over the temperatures of } 25,45 \text {, and } 65^{\circ} \mathrm{C} \text {. If viscosity of the } \\
\text { supernate from WTC is above } 5 \mathrm{cP} \text {, then WTC supernate will be } \\
\text { diluted } 20 \% \text { and viscosity measured. } \\
\text { A process test is being performed in accordance with a test plan } \\
\text { (Herting 1998). The largest observed quantity of settied solids for } \\
\text { WTC and WTC dilution of } 50 \% \text { at temperature of } 45^{\circ} \mathrm{C} \text { at } 48 \\
\text { hours after mixing will be determined. } \\
\text { A process test is being performed in accordance with a test plan } \\
\text { (Herting 1998). The test will determine the liquid phase density for } \\
\text { WTC and at a } 50 \% \text { dilution ratio over the temperature of } 45^{\circ} \mathrm{C} \text {. }\end{array}$ & $\begin{array}{l}\text { Determine viscosity, } \\
\text { SpG, suspended } \\
\text { solids (See Table 3, } \\
\text { Item \# 3). }\end{array}$ \\
\hline & $\begin{array}{l}\text { Confirm that the dilution ratio, } \\
\text { diluent composition, and waste } \\
\text { composition are balanced so gibbsite } \\
\text { or high viscosity slurries do not } \\
\text { precipitate }\end{array}$ & $\begin{array}{l}\text { An extended storage (at least one month) of supernate sub-samples } \\
\text { from the WTC dilution test at temperature of } 45^{\circ} \mathrm{C} \text { will be } \\
\text { observed for solid formation. } \\
\text { Special Consideration: If gibbsite will form, it should form within } \\
\text { four weeks. }\end{array}$ & $\begin{array}{l}\text { Determine solid } \\
\text { formation, if any (See } \\
\text { Table 3, Item \# 4). }\end{array}$ \\
\hline
\end{tabular}


Table 1. Base Case Operating Scenario Evaluation. (6 Sheets)

\begin{tabular}{|c|c|c|c|}
\hline Elements $^{\mathbf{a}}$ & Requirements $^{\mathrm{b}}$ & Discussion/evaluation & Information needs \\
\hline \multirow[t]{3}{*}{$\begin{array}{l}\text { Element 3, Mixing } \\
\text { Requirements }\end{array}$} & $\begin{array}{l}\text { Confirm that the portion of the solids } \\
\text { thought to be soluble are soluble and } \\
\text { that they dissolve in a reasonable } \\
\text { amount of time. }\end{array}$ & $\begin{array}{l}\text { The Base case operating scenario (Kirkbride et al. 1997) assumed } \\
\text { that the majority of the solids in } 241 \text {-AN-104 would dissolve. A } \\
\text { process test is being performed in accordance with a test plan } \\
\text { (Herting 1998). Amount of undissolved solids is being determined } \\
\text { at } 50 \% \text { dilution for temperature of } 45^{\circ} \mathrm{C} \text {. During the test, } \\
\text { amount of time needed to dissolve the sample will be recorded }\end{array}$ & $\begin{array}{l}\text { Amount of } \\
\text { undissolved solids } \\
\text { and the amount of } \\
\text { time needed to } \\
\text { dissolve the solids } \\
\text { (See Table 3, } \\
\text { Item \# 5). }\end{array}$ \\
\hline & $\begin{array}{l}\text { Confirm that the undissolved solids } \\
\text { settle and that they settle in a } \\
\text { reasonable amount of time. }\end{array}$ & $\begin{array}{l}\text { A process test is being performed to determine settling rate for the } \\
\text { undissolved solids. } \\
\text { Srale-un calculations for Herting's settling data wit! be performed. } \\
\text { The base case time allocated in the TWRSO\&UP (Kirkbride et al. } \\
\text { 1997, Assumption 6.11) for settling is taken by reference from } \\
\text { (Certa et al. 1996) and is } 30 \text { days. }\end{array}$ & $\begin{array}{l}\text { Settling rate for the } \\
\text { undissolved solids. } \\
\text { Estimated time to } \\
\text { settle undissolved } \\
\text { solids at full scale. } \\
\text { (See Table } 3 \text {, } \\
\text { Item \# 6). }\end{array}$ \\
\hline & $\begin{array}{l}\text { Confirm that the baseline retrieval } \\
\text { equipment that will be used to } \\
\text { mobilize and transfer the waste is } \\
\text { consistent with the operating } \\
\text { scenario. }\end{array}$ & $\begin{array}{l}\text { Tank 241-AN-104 contains about } 39 \% \text { by weight of a salt slurry. } \\
\text { (Hu 1997). The base case operating scenario targets most of the } \\
\text { sodium in the salt slurry for feed. The equipment required to } \\
\text { mobilize and retrieve the slurry includes mixer pumps and a } \\
\text { transfer pump with water (and caustic) dilution capability (Boston } \\
\text { 1997). This is consistent with the equipment identified in the base } \\
\text { case operating scenario (Kirkbride et al. 1997). } \\
\text { Retrieval equipment to be added to 241-AN-104 will accomplish } \\
\text { requirements. }\end{array}$ & $\begin{array}{l}\text { No further } \\
\text { information is } \\
\text { needed. }\end{array}$ \\
\hline
\end{tabular}


Table 1. Base Case Operating Scenario Evaluation. (6 Sheets)

\begin{tabular}{|c|c|c|c|}
\hline Elements $^{\mathrm{a}}$ & Requirements ${ }^{b}$ & Discussion/evaluation & Information needs \\
\hline \multirow[t]{2}{*}{$\begin{array}{l}\text { Element } 4 \text { - Part 1: } \\
\text { Envelope } \\
\text { Requirements } \\
\text { These limits apply to } \\
\text { the feed actually } \\
\text { delivered to the } \\
\text { private contractors. }\end{array}$} & $\begin{array}{l}\text { Concentration limits for the chemical } \\
\text { and radionuclide content of the feed } \\
\text { (DOE-RL 1996, Section C.6). } \\
\text { See Section 2.0, Tables } 1 \text { and } 2 \text { (in } \\
\text { main report) for the limits. }\end{array}$ & $\begin{array}{l}\text { Only Envelope A limits apply to Batch } 2 \text {. } \\
\text { The TWRSO\&UP (Kirkbride et al. 1997, Tables I-1 and I-3)) } \\
\text { compared the point estimates }{ }^{1} \text { of the composition of the feed from } \\
241-A N-104 \text { to the Envelope limits and "flagged" sulfate as } \\
\text { requiring further examination. The sulfate was at } 92 \% \text { of the } \\
\text { maximum limit of } 0.06 \text { gmole sulfate/gmole Na; All other analytes } \\
\text { were below } 80 \% \text { of their maximum limits. } \\
\text { Welsh (1998, Section } 7.1 \text { and } 7.2 \text { ) calculated the mean } \\
\text { concentration and UL for the bulk tank composition }{ }^{3} \text { using four } \\
\text { variations on segment data and two variations on composite data. } \\
\text { The means and UL for all analytes and methods were below the } \\
\text { maximum envelope limits, with the following exception: In two } \\
\text { variations based on segment data that used fusion digest slurry data } \\
\text { the means for Ba.icp, La.icp and U.icp and the UL for Ba.icp, } \\
\text { La.icp, Pb.icp, sulfate, Total alpha and U.icp exceeded their } \\
\text { respective envelope limits. These are "flagged" for further } \\
\text { consideration. }\end{array}$ & $\begin{array}{l}\text { Chemical and } \\
\text { radionuclide analyses } \\
\text { from Herting's tests } \\
\text { (See Table 3, } \\
\text { Item \# 7). }\end{array}$ \\
\hline & $\begin{array}{l}\text { Concentration limit for the sodium } \\
\text { concentration of the feed: } \\
3 \underline{M} \leq \text { [Na] } \leq 14 \mathrm{M} \text { (DOE-RL } \\
\text { 1996, Section C.6). }\end{array}$ & During Herting's process test [Na] will be measured. & $\begin{array}{l}\text { [Na] measurement } \\
\text { (See Table 3, } \\
\text { Item \# 8). }\end{array}$ \\
\hline
\end{tabular}

${ }^{1}$ These point estimates were based on the best basis inventory for 241-AN-104. A thermodynamic model (ESP) was used to estimate the liquid phase composition of the diluted waste.

2 The UL is the upper 95 percent confidence interval for random variability.

${ }^{3}$ For 241-AN-104, the bulk inventory can be used as a bounding case in estimating the analyte:Na ratios. The quantity of each bulk analyte inventory will be equal to or greater than that in the liquid phase of the diluted waste. The bulk quantity of sodium in the tank will be about the same as the sodium in the liquid phase after dilution with water since nearly all of the sodium has been removed from the solids at a $50 \%$ or greater dilution. Any bias in the analyte:Na mole ratios estimated directly from the bulk inventory will tend to be high (that is, conservative for comparison to maximum envelope limits). 
Table 1. Base Case Operating Scenario Evaluation. (6 Sheets)

\begin{tabular}{|c|c|c|c|}
\hline Elements $^{\mathrm{a}}$ & Requirements $^{\mathbf{b}}$ & Discussion/evaluation & Information needs \\
\hline \multirow[t]{2}{*}{$\begin{array}{l}\text { Element } 4 \text { - Part 1: } \\
\text { Envelope } \\
\text { Requirements } \\
\text { (continued) }\end{array}$} & $\begin{array}{l}\text { Insoluble solids fraction limit will } \\
\text { not exceed } 5 \text { volume \% (DOE-RL } \\
\text { 1996, Section C.6). }\end{array}$ & $\begin{array}{l}\text { The contracts do not define how the volume percent insoluble solids } \\
\text { will be measured. } \\
\text { Herting (1998) will measure the quantity of solids for WTC dilution } \\
\text { of } 50 \% \text { at temperature of } 45^{\circ} \mathrm{C} \text {. }\end{array}$ & $\begin{array}{l}\text { Insoluble solids } \\
\text { measurement (See } \\
\text { Table 3, Item \# 9). }\end{array}$ \\
\hline & $\begin{array}{l}\text { Operating Specifications from } \\
\text { OSD-T-151-00007 (DOE-RL 1996, } \\
\text { Section C.6 invokes the OSD by } \\
\text { reference). } \\
\text { See Section } 2.0 \text {, Table } 3 \text { (in main } \\
\text { report). }\end{array}$ & 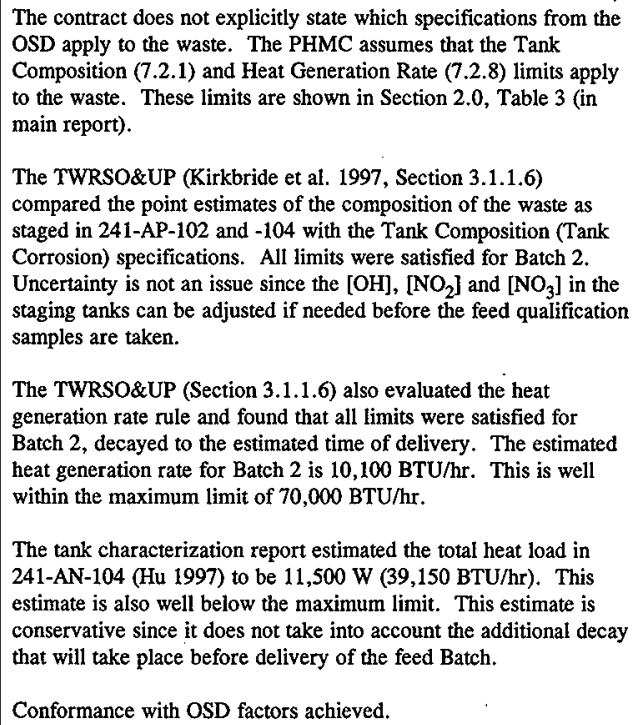 & $\begin{array}{l}\text { No further } \\
\text { information is } \\
\text { needed. }\end{array}$ \\
\hline
\end{tabular}


Table 1. Base Case Operating Scenario Evaluation. (6 Sheets)

\begin{tabular}{|c|c|c|c|}
\hline Elements $^{a}$ & Requirements $^{b}$ & Discussion/evaluation & Information needs \\
\hline \multirow[t]{2}{*}{$\begin{array}{l}\text { Element } 4 \text { - Part 1: } \\
\text { Envelope } \\
\text { Requirements } \\
\text { (continued) }\end{array}$} & $\begin{array}{l}\text { Maximum }{ }^{137} \mathrm{Cs} \text { concentration of } \\
5.86 \mathrm{E} 10 \mathrm{~Bq} / \mathrm{liter}(6 \mathrm{Ci} / \mathrm{gal}) \text {. }\end{array}$ & $\begin{array}{l}\text { This limit is equivalent to } 1.59 \mathrm{E} 6 \mu \mathrm{Ci} / \mathrm{L} \text {. The OSD limit of } \\
5.74 \mathrm{E} 5 \mu \mathrm{Ci} / \mathrm{L} \text { is more restrictive. } \\
\text { Using the best basis inventory and reported volume for } 241-\mathrm{AN}-104 \\
\text { from } \mathrm{Hu}(1997) \text {, the bulk [137Cs] is calculated to be } 5.8 \mathrm{E} 5 \mu \mathrm{Ci} / \mathrm{L} \\
\text { and }[90 \mathrm{Sr}] \text { is } 2.4 \mathrm{E} 4 \mu \mathrm{Ci} / \mathrm{L} \text {. These are both well below the OSD } \\
\text { limits of } 5.74 \mathrm{E} 5 \mu \mathrm{Ci} / \mathrm{L} \text { and } 4.04 \mathrm{E} 5 \mu \mathrm{Ci} / \mathrm{L} \text {, respectively. This is a } \\
\text { conservative comparison since the } 50 \% \text { dilution has not been } \\
\text { accounted for in the above estimates. } \\
\text { Conformance with maximum }{ }^{137} \mathrm{Cs} \text { concentration achieved. }\end{array}$ & $\begin{array}{l}\text { No further } \\
\text { information is } \\
\text { needed. }\end{array}$ \\
\hline & $\begin{array}{l}\text { The PHMC assumed minimum limits } \\
\text { to distinguish between Envelope A } \\
\text { and C and between Envelopes A } \\
\text { and B }\end{array}$ & $\begin{array}{l}\text { These discriminators do not apply to Batch } 2 \text { (Envelope A). } \\
\text { No concern about distinguishing between envelopes. }\end{array}$ & $\begin{array}{l}\text { No further } \\
\text { information is } \\
\text { needed. }\end{array}$ \\
\hline \multirow[t]{3}{*}{$\begin{array}{l}\text { Element } 4 \text { - Part 2: } \\
\text { Quantity } \\
\text { Requirements }\end{array}$} & $\begin{array}{l}\text { Batch size (mass of sodium) } \\
\text { constraints (from the contracts) z } \\
\text { 100 MT Na. }\end{array}$ & $\begin{array}{l}\text { During Herting's process test, amount of } \mathrm{Na} \text { recoverable will be } \\
\text { measured at } 50 \% \text { dilution ratio }\end{array}$ & $\begin{array}{l}\text { Determine Na } \\
\text { quantity (See Table 3, } \\
\text { Item \# 10). }\end{array}$ \\
\hline & $\begin{array}{l}\text { PHMC targeted batch size range } \\
\text { (from the ICD (PHMC 1997, } \\
\text { Table 3D): } 250-600 \text { MT Na. }\end{array}$ & Same as above. & $\begin{array}{l}\text { Determine Na } \\
\text { quantity (See Table 3, } \\
\text { Item \# 10). }\end{array}$ \\
\hline & $\begin{array}{l}\text { PHMC desired batch size (from } \\
\text { Operating Scenario): } 535 \mathrm{MT} \mathrm{Na} \\
\text { (Kirkbride et al. 1997, Table 3.1-5) }\end{array}$ & Same as above. & $\begin{array}{l}\text { Determine Na } \\
\text { quantity (See Table 3, } \\
\text { Item \# 10). }\end{array}$ \\
\hline
\end{tabular}


Table 1. Base Case Operating Scenario Evaluation. (6 Sheets)

\begin{tabular}{|l|l|l|l|}
\hline \multicolumn{1}{|c|}{ Elements $^{\mathrm{a}}$} & \multicolumn{1}{|c|}{ Requirements $^{\mathrm{b}}$} & \multicolumn{1}{c|}{ Discussion/evaluation } & \multicolumn{1}{|c|}{ Information needs } \\
\hline $\begin{array}{l}\text { Element } 5 \text { - } \\
\text { Miscellaneous Inputs }\end{array}$ & Physical form of Tank T contents & $\begin{array}{l}\text { From Hu (1997): 241-AN-104 has a noncontinuous floating crust } \\
\text { layer that may be up to } 5.1 \mathrm{~cm} \text { (2 in) thick. The layer is easily } \\
\text { penetrated and is composed of easily dissolvable salts. There is } \\
\text { approximately 5.5 } \mathrm{m} \text { (18 ft) of supernate which is compositionally } \\
\text { homogenous. There are approximately 4.1 m (13.6 ft) of settled } \\
\text { solids. There is no hard pan. }\end{array}$ & $\begin{array}{l}\text { No further } \\
\text { information is needed }\end{array}$ \\
\cline { 2 - 4 } & $\begin{array}{l}\text { Heel from prior batch remaining in } \\
\text { staging tanks }\end{array}$ & $\begin{array}{l}\text { Heels remaining from clean out of 241-AP-102 and -104 are } \\
\text { addressed in Section 2.1 above. }\end{array}$ & $\begin{array}{l}\text { No further } \\
\text { information is needed }\end{array}$ \\
\cline { 2 - 5 } & Shimming Batch 2 & No shimming is anticipated. & $\begin{array}{l}\text { No further } \\
\text { information is needed }\end{array}$ \\
\cline { 2 - 5 } & RL direction & $\begin{array}{l}\text { No changes to applicable M\&I ICD requirements have been made } \\
\text { to date. }\end{array}$ & $\begin{array}{l}\text { No further } \\
\text { information is needed }\end{array}$ \\
\hline
\end{tabular}

a. Elements are taken from the Decision Rule statement in Section 6.1 of PSDQ0-01.

b. Requirements are taken from Sections 4.1, 4.2, 4.3, 4.4, and 4.5 of PSDQO-01. 
Table 2. Alternative Case Operating Scenario Evaluation. (4 Sheets)

\begin{tabular}{|c|c|c|c|}
\hline Elements $^{\mathrm{a}}$ & Requirements ${ }^{b}$ & Discussion/evaluation & Information needs \\
\hline \multirow[t]{2}{*}{$\begin{array}{l}\text { Element 1, Dilution } \\
\text { Ratio and Diluent } \\
\text { Composition }\end{array}$} & \multirow[t]{2}{*}{$\begin{array}{l}\text { Determine the desired dilution ratio } \\
\text { and diluent composition for each } \\
\text { waste transfer. }\end{array}$} & $\begin{array}{l}\text { (a) As applied to supernate composite: A process test is being } \\
\text { performed (Herting 1998). The test plan was based on instruction } \\
\text { provided by the Disposal Program (Garfield 1997). } \\
\text { This information is being obtained per Herting's process test (1998). }\end{array}$ & $\begin{array}{l}\text { Desired dilution ratio } \\
\text { and diluent } \\
\text { composition for a } \\
\text { representative sample } \\
\text { of supernate (See } \\
\text { Table 3, Item \# 11) }\end{array}$ \\
\hline & & $\begin{array}{l}\text { (b) As applied to salt slurry composite: A process test is being } \\
\text { performed (Herting 1998). The test plan was based on instruction } \\
\text { provided by the Disposal Program (Garfield 1997). } \\
\text { This information is being obtained per Herting's process test (1998). }\end{array}$ & $\begin{array}{l}\text { Desired dilution ratio } \\
\text { and diluent } \\
\text { composition for a } \\
\text { representative sample } \\
\text { of salt slurry (See } \\
\text { Table 3, Item \# 11) }\end{array}$ \\
\hline \multirow[t]{5}{*}{$\begin{array}{l}\text { Element } 2 \text {, Transfer } \\
\text { Requirements are } \\
\text { Satisfied }\end{array}$} & \multirow{2}{*}{$\begin{array}{l}\text { Confirm that the as-retrieved waste } \\
\text { (including dilution water or caustic) } \\
\text { remains below saturation in major } \\
\text { Na salts during the transfer to the } \\
\text { staging tank. }\end{array}$} & $\begin{array}{l}\text { (a) As applied to supernate composite with proper amount of diluent } \\
\text { added: A process test is being performed (Herting 1998). }\end{array}$ & $\begin{array}{l}\text { See requirement (See } \\
\text { Table 3, Item \# 12). }\end{array}$ \\
\hline & & $\begin{array}{l}\text { (b) As applied to salt slurry composite with proper amount of diluent } \\
\text { added: A process test is being performed (Herting 1998). }\end{array}$ & $\begin{array}{l}\text { See requirement (See } \\
\text { Table 3, Item \# 12). }\end{array}$ \\
\hline & \multirow{2}{*}{$\begin{array}{l}\text { Confirm that the as-retrieved waste } \\
\text { (including dilution water or caustic) } \\
\text { remain at or below viscosity of } \\
10 \mathrm{cP} \text {, at or below a } 1.5 \mathrm{SpG} \text {, and at } \\
\text { or below } 30 \text { percent solids by } \\
\text { volume during the transfer to the } \\
\text { staging tank. }\end{array}$} & $\begin{array}{l}\text { (a) As applied to supernate composite with proper amount of diluent } \\
\text { added: A process test is being performed (Herting 1998). }\end{array}$ & $\begin{array}{l}\text { See requirement (See } \\
\text { Table 3, Item \# 13). }\end{array}$ \\
\hline & & $\begin{array}{l}\text { (b) As applied to salt slurry composite with proper amount of diluent } \\
\text { added: A process test is being performed (Herting 1998). }\end{array}$ & $\begin{array}{l}\text { See requirement (See } \\
\text { Table 3, Item \# 13). }\end{array}$ \\
\hline & $\begin{array}{l}\text { Confirm that the dilution ratio, } \\
\text { diluent composition, and waste } \\
\text { composition are balanced so gibbsite } \\
\text { or high viscosity slurries do not } \\
\text { precipitate. }\end{array}$ & A process test is being performed (Herting 1998). & $\begin{array}{l}\text { Precipitation at } 0,40 \text {, } \\
80 \text {, and } 120 \% \\
\text { dilution (See Table } 3 \text {, } \\
\text { Item \# 14). }\end{array}$ \\
\hline
\end{tabular}


Table 2. Alternative Case Operating Scenario Evaluation. (4 Sheets)

\begin{tabular}{|c|c|c|c|}
\hline Elements $^{a}$ & Requirements ${ }^{b}$ & Discussion/evaluation & Information needs \\
\hline \multirow[t]{3}{*}{$\begin{array}{l}\text { Element 3, } \\
\text { Dissolution } \\
\text { Requirements }\end{array}$} & $\begin{array}{l}\text { Confirm that the portion of the } \\
\text { solids thought to be soluble are } \\
\text { soluble and that they dissolve in a } \\
\text { reasonable amount of time. }\end{array}$ & $\begin{array}{l}\text { The Base case operating scenario (Kirkbride et al. 1997) assumed that } \\
\text { the majority of the solids in 241-AN-104 would dissolve. } \\
\text { A process test is being performed (Herting 1998). }\end{array}$ & $\begin{array}{l}\text { Amount of soluble } \\
\text { solids and amount of } \\
\text { time required to } \\
\text { dissolve soluble solids } \\
\text { (See Table } 3 \text {, } \\
\text { Item \# 15). }\end{array}$ \\
\hline & $\begin{array}{l}\text { Confirm that the undissolved solids } \\
\text { settle and that they settle in a } \\
\text { reasonable amount of time. }\end{array}$ & $\begin{array}{l}\text { A process test is being performed to determine settling rate for the } \\
\text { undissolved solids. } \\
\text { Scale-up calculations for Herting's settling data have not been } \\
\text { performed. }\end{array}$ & $\begin{array}{l}\text { Settling rate for the } \\
\text { undissolved solids. } \\
\text { Estimated time to } \\
\text { settle undissolved } \\
\text { solids at full scale } \\
\text { (See Table 3, } \\
\text { Item \# 16). }\end{array}$ \\
\hline & $\begin{array}{l}\text { Confirm that the baseline retrieval } \\
\text { equipment that will be used to } \\
\text { mobilize and transfer the waste is } \\
\text { consistent with the operating } \\
\text { scenario. }\end{array}$ & $\begin{array}{l}\text { The alternative case uses the same retrieval equipment as the base case. } \\
\text { See base case evaluation for details. } \\
\text { Retrieval equipment to be added to AN-104 will accomplish } \\
\text { requirements. }\end{array}$ & $\begin{array}{l}\text { No further } \\
\text { information is } \\
\text { needed. }\end{array}$ \\
\hline $\begin{array}{l}\text { Element } 4 \text { - Part 1: } \\
\text { Envelope } \\
\text { Requirements } \\
\text { These limits apply to } \\
\text { the feed actually } \\
\text { delivered to the } \\
\text { private contractors. }\end{array}$ & $\begin{array}{l}\text { Concentration limits for the } \\
\text { chemical and radionuclide content of } \\
\text { the feed (DOE-RL 1996, } \\
\text { Section C.6). } \\
\text { See Section } 2.0 \text {, Tables } 1 \text { and } 2 \text { (in } \\
\text { main report) for the limits. }\end{array}$ & $\begin{array}{l}\text { Only Envelope A limits apply to Batch } 2 \text {. } \\
\text { In the alternative case, the composition of the waste staged in } \\
241-\mathrm{AP}-102 \text { and }-104 \text { is almost identical to that of the base case. There } \\
\text { will be differences in absolute concentration due to differences in the } \\
\text { total amount of dilution, but this will not affect the [analyte]:[Na] } \\
\text { values. There will also be differences due to slightly different extent of } \\
\text { solids dissolution, but these are bounded by the evaluation for the Base } \\
\text { Case that was based on the Welsh (1998) report. }\end{array}$ & $\begin{array}{l}\text { Chemical and } \\
\text { radionuclide analyses } \\
\text { from Herting's tests } \\
\text { (See Table 3, } \\
\text { Item \# 7). }\end{array}$ \\
\hline
\end{tabular}


Table 2. Alternative Case Operating Scenario Evaluation. (4 Sheets)

\begin{tabular}{|c|c|c|c|}
\hline Elements $^{\mathrm{a}}$ & Requirements $^{b}$ & Discussion/evaluation & Information needs \\
\hline \multirow[t]{4}{*}{$\begin{array}{l}\text { Element } 4 \text { - Part 1: } \\
\text { Envelope } \\
\text { Requirements } \\
\text { (continued) }\end{array}$} & $\begin{array}{l}\text { Concentration limit for the sodium } \\
\text { concentration of the feed: } \\
3 \mathrm{M} \leq[\mathrm{Na}] \leq 14 \mathrm{M} \text { (DOE-RL } \\
1996 \text {, Section C.6). }\end{array}$ & $\begin{array}{l}\text { Since the supernate dilution ratio was not established, the resulting [Na] } \\
\text { in the Batch can not be directly determined. However, a bounding } \\
\text { calculation shows that the lower limit will be satisfied: Assume that the } \\
\text { dilution ratio required by the supernate layer will be equal to the } \\
\text { dilution ratio required by the salt slurry layer. The lowest ( } 95 \% \mathrm{CI} \\
\text { around the mean for the various statistical models and analytical } \\
\text { methods employed) estimate of the bulk [Na] was } 12.1 \mathrm{M} \text { (Welsh } 1998 \text {, } \\
\text { Section } 7) \text {. The lowest [Na] in the feed batch is the [Na] } \\
\text { bulk/( } 1+120 \% / 100 \%) \text { to account for } 120 \% \text { dilution). This yields a } \\
\text { value of } 5.5 \mathrm{M} \text {. } \\
\text { The sodium concentration for the feed batch can be adjusted in the } \\
\text { intermediate feed staging tanks. } \\
\text { Compliance with Na molarity achieved. }\end{array}$ & $\begin{array}{l}\text { No further } \\
\text { information is } \\
\text { needed. }\end{array}$ \\
\hline & $\begin{array}{l}\text { Insoluble solids fraction limit will } \\
\text { not exceed } 5 \text { volume \% (DOE-RL } \\
\text { 1996, Section C.6). }\end{array}$ & $\begin{array}{l}\text { In the alternative case, the only solids that should end up in the feed } \\
\text { batch are those solids that are inadvertently entrained during the decant } \\
\text { transfers. This is an operational issue, not a "Confirm Tank T..." issue. } \\
\text { Compliance with insoluble fraction will be resolved by case during } \\
\text { operations. }\end{array}$ & $\begin{array}{l}\text { No further } \\
\text { information is } \\
\text { needed. }\end{array}$ \\
\hline & $\begin{array}{l}\text { Operating Specifications from } \\
\text { OSD-T-151-00007 (DOE-RL 1996, } \\
\text { Section C. } 6 \text { invokes the OSD by } \\
\text { reference). } \\
\text { See Section } 2.0 \text {, Table } 3 \text { (in main } \\
\text { report). }\end{array}$ & $\begin{array}{l}\text { Mass balances have not been performed on the alternative case } \\
\text { operating scenario to estimate the composition of the staged feed batch } \\
\text { (these can be done explicitly after the supernate dilution ratio has been } \\
\text { determined. Bounding calculations can be performed, however it is } \\
\text { simpler to wait for the dilution ratio. }\end{array}$ & $\begin{array}{l}\text { Estimated } \\
\text { composition of the } \\
\text { staged feed (See } \\
\text { Table 3, Item \# 16). }\end{array}$ \\
\hline & $\begin{array}{l}\text { Maximum }{ }^{137} \mathrm{Cs} \text { concentration of } \\
5.86 \mathrm{E} 10 \mathrm{~Bq} / \mathrm{liter}(6 \mathrm{Ci} / \mathrm{gal}) .\end{array}$ & $\begin{array}{l}\text { This limit is equivalent to } 1.59 \mathrm{E} 6 \mu \mathrm{Ci} / \mathrm{L} \text {. } \\
\text { Using the best basis inventory and reported volume for } 241-\mathrm{AN}-104 \\
\text { from } \mathrm{Hu}(1997 \text { ), the bulk [137Cs] is calculated to be } 5.8 \mathrm{ES} \mu \mathrm{Ci} / \mathrm{L} \text {. } \\
\text { This is well below the } \mathrm{OSD} \text { limit of } 1.59 \mathrm{E} 6 \mu \mathrm{Ci} / \mathrm{L} \text {. This is a } \\
\text { conservative comparison since dilution has not been included. } \\
\text { Conformance with maximum Cs achieved. }\end{array}$ & $\begin{array}{l}\text { No further } \\
\text { information is } \\
\text { needed. }\end{array}$ \\
\hline
\end{tabular}


Table 2. Alternative Case Operating Scenario Evaluation. (4 Sheets)

\begin{tabular}{|c|c|c|c|}
\hline Elements $^{\mathrm{a}}$ & Requirements $^{b}$ & Discussion/evaluation & Information needs \\
\hline $\begin{array}{l}\text { Element } 4 \text { - Part } 1: \\
\text { Envelope } \\
\text { Requirements } \\
\text { (continued) }\end{array}$ & $\begin{array}{l}\text { The PHMC assumed minimum } \\
\text { limits to distinguish between } \\
\text { Envelope } A \text { and } C \text { and between } \\
\text { Envelopes } A \text { and } B\end{array}$ & $\begin{array}{l}\text { These discriminators do not apply to Batch } 2 \text { (Envelope A). } \\
\text { No concern about distinguishing between envelopes. }\end{array}$ & $\begin{array}{l}\text { No further } \\
\text { information is } \\
\text { needed. }\end{array}$ \\
\hline \multirow{3}{*}{$\begin{array}{l}\text { Element } 4 \text { - Part } 2: \\
\text { Quantity } \\
\text { Requirements are } \\
\text { Satisfied }\end{array}$} & $\begin{array}{l}\text { Batch size (mass of sodium) } \\
\text { constraints (from the contracts) } 2 \\
100 \mathrm{MT} \mathrm{Na} \text {. }\end{array}$ & $\begin{array}{l}\text { During Herting's process test, amount of } \mathrm{Na} \text { recoverable will be } \\
\text { measured. }\end{array}$ & $\begin{array}{l}\text { Determine } \mathrm{Na} \\
\text { quantity (See Table } 3 \text {, } \\
\text { Item \# 10). }\end{array}$ \\
\hline & $\begin{array}{l}\text { PHMC targeted batch size range } \\
\text { (from the ICD (PHMC } 1997 \text {, } \\
\text { Table 3D): } 250-600 \mathrm{MT} \mathrm{Na} \text {. }\end{array}$ & Same as above. & $\begin{array}{l}\text { No further } \\
\text { information is } \\
\text { needed. }\end{array}$ \\
\hline & $\begin{array}{l}\text { PHMC desired batch size (from } \\
\text { Operating Scenario): } 535 \text { MT Na } \\
\text { (Kirkbride et al. 1997, Table 3.1-5) }\end{array}$ & $\begin{array}{l}\text { Same as above. } \\
\text { Na quantity requirements will be resolved administratively or by } \\
\text { shimming. }\end{array}$ & $\begin{array}{l}\text { No further } \\
\text { information is } \\
\text { needed. }\end{array}$ \\
\hline \multirow[t]{4}{*}{$\begin{array}{l}\text { Element } 5 \text { - } \\
\text { Miscellaneous Inputs }\end{array}$} & Physical form of Tank $T$ contents & $\begin{array}{l}\text { From Hu (1997): } 241-\mathrm{AN}-104 \text { has a noncontinuous floating crust layer } \\
\text { that may be up to } 5.1 \mathrm{~cm}(2 \mathrm{in}) \text { thick. The layer is easily penetrated } \\
\text { and is composed of easily dissolvable salts. There is approximately } \\
5.5 \mathrm{~m}(18 \mathrm{ft}) \text { of supernate which is compositionally homogenous. There } \\
\text { are approximately } 4.1 \mathrm{~m}(13.6 \mathrm{ft}) \text { of settled solids. There is no hard } \\
\text { pan. }\end{array}$ & $\begin{array}{l}\text { No further } \\
\text { information is needed }\end{array}$ \\
\hline & $\begin{array}{l}\text { Heel from prior batch remaining in } \\
\text { staging tanks }\end{array}$ & $\begin{array}{l}\text { Heels remaining from clean out of } 241-\mathrm{AP}-102 \text { and }-104 \text { are addressed } \\
\text { in Section } 2.1 \text { above. }\end{array}$ & $\begin{array}{l}\text { No further } \\
\text { information is needed }\end{array}$ \\
\hline & Shimming Batch 2 & No shimming is anticipated. & $\begin{array}{l}\text { No further } \\
\text { information is needed }\end{array}$ \\
\hline & RL direction & $\begin{array}{l}\text { No changes to applicable M\&I ICD requirements have been made to } \\
\text { date. }\end{array}$ & $\begin{array}{l}\text { No further } \\
\text { information is needed }\end{array}$ \\
\hline
\end{tabular}

${ }^{\mathrm{a}}$ Elements are taken from the Decision Rule statement in Section 6.1 of PSDQO-01.

${ }^{b}$ Requirements are taken from Sections 4.1, 4.2, 4.3, 4.4, and 4.5 of PSDQO-01. 
Table 3 was developed jointly by TWRS Characterization and Tank Waste Retrieval. It is intended to show what information is still needed, what can be obtained by calculations with existing data, what requires new (or existing) samples, analysis and/or process testing. Where samples are required, the amount and "representativeness" of the sample will be stated. Where analysis is needed, the specific analytes and QA requirements will be stated. If process testing is needed, the amount of sample and goals of the process test will be stated. Appropriate level of end description of QA requirements will be covered in the specific work plan for these limited process tests.

Table 3. Information Needs. (2 Sheets)

\begin{tabular}{|c|c|c|c|}
\hline Item & Information need & Planned resolution & $\begin{array}{l}\text { Sample } \\
\text { required }\end{array}$ \\
\hline 1 & $\begin{array}{l}\text { Desired dilution ratio } \\
\text { and diluent composition }\end{array}$ & A process test is being performed & None \\
\hline 2 & $\begin{array}{l}\text { Confirm a dilution ratio } \\
\text { of } 50 \% \text { for the WTC is } \\
\text { below saturation in major } \\
\text { Na salts }\end{array}$ & A process test is being performed & None \\
\hline 3 & $\begin{array}{l}\text { Determine viscosity, } \\
\text { SpG, suspended solids }\end{array}$ & A process test is being performed & None \\
\hline 4 & $\begin{array}{l}\text { Determine solid } \\
\text { formation, if any }\end{array}$ & A process test is being performed & None \\
\hline 5 & $\begin{array}{l}\text { Amount of undissolved } \\
\text { solids and the amount of } \\
\text { time needed to dissolve } \\
\text { the solids }\end{array}$ & A process test is being performed & None \\
\hline 6 & $\begin{array}{l}\text { Estimate time to settle } \\
\text { undissolved solids at full } \\
\text { scale }\end{array}$ & $\begin{array}{l}\text { Engineering calculations: no additional } \\
\text { tests required }\end{array}$ & None \\
\hline 7 & $\begin{array}{l}\text { Chemical and } \\
\text { radionuclide analyses } \\
\text { from Herting's test }\end{array}$ & A process test is being performed & None \\
\hline 8 & [Na] measurement & A process test is being performed & None \\
\hline 9 & $\begin{array}{l}\text { Insoluble solids } \\
\text { measurement }\end{array}$ & A process test is being performed & None \\
\hline 10 & $\begin{array}{l}\text { Determination of } \mathrm{Na} \\
\text { quantity }\end{array}$ & A process test is being performed & None \\
\hline
\end{tabular}


HNF-2799

Revision 0

Table 3. Information Needs. (2 Sheets)

\begin{tabular}{|c|c|c|c|}
\hline Item & Information need & Planned resolution & $\begin{array}{l}\text { Sample } \\
\text { required }\end{array}$ \\
\hline 11 & $\begin{array}{l}\text { Desired dilution ratio } \\
\text { and diluent composition } \\
\text { for a representative } \\
\text { sample of supernate. }\end{array}$ & $\begin{array}{l}\text { Calculate from results of Item } \# 12 \text { and } \\
\text { ESP. No additional tests required. }\end{array}$ & None \\
\hline 12 & $\begin{array}{l}\text { Confirm as-retrieved } \\
\text { waste remains below satn } \\
\text { in major NA saits during } \\
\text { transfer. }\end{array}$ & $\begin{array}{l}\text { Performing lab test: measure \%solids vs. } \\
\text { temp for supernate at } 25,45 \text { and } 65^{\circ} \mathrm{C} \\
\text { under } 3 \text { conditions: undiluted, } 10 \% \\
\text { diluted and } 20 \% \text { diluted. }\end{array}$ & None \\
\hline 13 & $\begin{array}{l}\text { Confirm as-retrieved } \\
\text { waste remains }<10 \mathrm{cP} \text {, } \\
<1.5 \mathrm{SpG} \text {, and }<30 \% \\
\text { solids during transfer. }\end{array}$ & $\begin{array}{l}\text { SpG, viscosity and \%Solids are being } \\
\text { measured. }\end{array}$ & None \\
\hline 14 & $\begin{array}{l}\text { Precipitation at } 0,40, \\
80, \text { and } 120 \% \text { dilutions }\end{array}$ & $\begin{array}{l}\text { Process testing is being performed at these } \\
\text { dilutions. }\end{array}$ & None \\
\hline 15 & $\begin{array}{l}\text { Amount of soluble solids } \\
\text { and amount time needed } \\
\text { to dissolve soluble } \\
\text { solids. }\end{array}$ & A process test is being performed. & None \\
\hline 16 & $\begin{array}{l}\text { Estimate composition of } \\
\text { staged feed. }\end{array}$ & $\begin{array}{l}\text { Can be calculated from existing data after } \\
\text { item \#11 is resolved. }\end{array}$ & None \\
\hline
\end{tabular}

There are 16 items that have been flagged in Tables 1 and 2 requiring further information. All items are being addressed by a specific process test with specific material from 241-AN-104. There are no other information needs requiring either an analysis of an existing 241-AN-104 sample or the collection of additional sample followed by analysis in order to confirm that tank 241-AN-104 is appropriate for Batch 2. 
HNF-2799

Revision 0

\subsection{REFERENCES}

Boston, H. L., 1997, Subcontract Number 80232764-9-K001, Design Basis for Retrieval Equipment in Tanks AN-104 and AN-105, Letter to A. M. Umek (Fluor Daniel Hanford, Incorporated), LMHC-9758071, Lockheed Martin Hanford Corporation, Richland, Washington.

Certa, P. J., W. H. Grams, C. M. McConville, L. W. Shelton and E. J. Slaathaug, 1996, Low-Level Waste Feed Staging Plan, WHC-SD-WM-RPT-224, Rev. 0, Westinghouse Hanford Company, Richland, Washington.

DOE-RL, 1996, TWRS Privatization, Contract Numbers DE-RP06-96RL13308 and 13309, U.S. Department of Energy, Richland, Washington.

Garfield, J. S., 1997, Tank 241-AN-104 Dilution/Dissolution Test Requirements, Internal memo to D. L. Herting, 8C451-97-004 (March 27), Numatec Hanford Corporation, Richland, Washington.

Herting, D. L, 1998, Test Plan for Tank 241-AN-104 Dilution Studies, HNF-1863, Rev. 0, Numatec Hanford Corporation, Richland, Washington.

Hu, T. A., L. W. Shelton, and T. L. Welsh, 1997, Tank Characterization Report for DoubleShell Tank 24l-AN-104, HNF-SD-WM-ER-690, Rev. 0, Lockheed Martin Hanford Company, Richland, Washington.

Kirkbride, R. A., G. K. Allen, P. J. Certa, A. F. Manuel, R. M. Orme, L. W. Shelton, E. J. Slaathaug, R. S. Wittman, G. T. MacLean and D. L. Penwell, 1997, Tank Waste Remediation System Operation and Utilization Plan, HNF-SD-WM-SP-012, Rev. 0A, Vol. I and II, Numatec Hanford Corporation, Richland, Washington.

PHMC, 1996, Unclassified Operating Specification for the 241-AN, AP, AW, AY, AZ, and SY Tank Farms, OSD-T-151-00007, Rev. H-18, Fluor Daniel Hanford, Richland, Washington.

PHMC, 1997, Interface Control Document Between DOE and the PHMC, Low-Activity Waste Feed, HNF-SP-1223 (ICD-19), Project Hanford Management Contractor, Richland, Washington.

Welsh, T. L. and L. Jensen, 1998, Waste Envelope "A" Comparison, 241-AN-104, HNF-SD-WM-TI-823, Rev. 0 (January 1998 draft), B\&W Protec, Inc., Richland, Washington. 


\title{
ADDENDUM 3
}

\author{
APPLICATION OF
}

\section{"CONFIRM TANK T IS AN APPROPRIATE FEED SOURCE FOR LOW-ACTIVITY WASTE FEED BATCH $X^{\prime \prime}$}

\section{TO}

241-AW-101 / BATCH 3 
HNF-2799

Revision 0

This page intentionally left blank.

Addendum 3-2 
HNF-2799

Revision 0

\section{CONTENTS}

1.0 INTRODUCTION $\ldots \ldots \ldots \ldots \ldots \ldots \ldots \ldots \ldots$ Addendum $3-5$

2.0 EVALUATION $\ldots \ldots \ldots \ldots \ldots \ldots \ldots \ldots \ldots \ldots \ldots \ldots \ldots \ldots \ldots$ Addendum $3-7$

2.1 BASE CASE OPERATING SCENARIO $\ldots \ldots \ldots \ldots \ldots$ Addendum 3-7

2.2 ALTERNATIVE CASE OPERATING SCENARIO $\ldots \ldots \ldots$ Addendum 3-8

3.0 REFERENCES $\ldots \ldots \ldots \ldots \ldots \ldots \ldots \ldots \ldots \ldots \ldots \ldots \ldots \ldots \ldots$ Addendum $3-22$

\section{LIST OF TABLES}

1. Base Case Operating Scenario Evaluation $\ldots \ldots \ldots \ldots \ldots$ Addendum 3-11

2. Alternative Case Operating Scenario Evaluation $\ldots \ldots \ldots \ldots \ldots$ Addendum 3-16

3. Information Needs. $\ldots \ldots \ldots \ldots \ldots \ldots \ldots \ldots \ldots$ Addendum $3-20$ 
HNF-2799

Revision 0

\section{LIST OF TERMS}

DOE U.S. Department of Energy

ICD Interface Control Document

LAW Low-Activity Waste

M Molar (gmoles/liter)

PHMC Project Hanford Management Contract(or)

PMBS Project Master Baseline Schedule

PSDQO Problem-Specific Data Quality Objectives

RL U.S. Department of Energy-Richland Operations

TANK T Refers to the contents from one tank, multiple tanks, or portions of one or more tanks that will be used to prepare a feed batch

TOC Total Organic Carbon

TWRS Tank Waste Remediation System

TWRSO\&UP Tank Waste Remediation System Operation and Utilization Plan

USQ Unreviewed Safety Question

WIT Waste Disposal Integration Team

WTC Whole tank composite 
HNF-2799

Revision 0

\section{APPLICATION OF "CONFIRM TANK T IS AN APPROPRIATE FEED SOURCE FOR LOW-ACTIVITY WASTE FEED BATCH X" TO 241-AW-101 / BATCH 3}

\subsection{INTRODUCTION}

This addendum applies Revision 1 of "Confirm Tank $T$ is an Appropriate Feed Source for Low-Activity Waste Feed Batch X" problem-specific data quality objectives (PSDQO) to tank 241-AW-101 / Batch 3.

This application of the DQO is divided into a Base Case Operating Scenario and an Alternative Case Operating Scenario. The Base Case homogenizes the waste in tank 241-AW-101 by mixing prior to transfer to 241-AP-102 and -104. The Alternative Case transfers the tank 241-AW-101 supernate to 241-AP-102 and -104 without mixing followed by subsequent diluent addition and mixing in 241-AW-101 before transfer to 241-AP-102 and -104 . 
HNF-2799

Revision 0

This page intentionally left blank.

Addendum 3-6 
HNF-2799

Revision 0

\subsection{EVALUATION}

\subsection{BASE CASE OPERATING SCENARIO}

Translate the operating scenario into a series of process steps.

The base case operating scenario from the Tank Waste Remediation System Operation and Utilization Plan (TWRSO\&UP) (Kirkbride et al. 1997) includes the following steps to make up Batch 3:

- Empty 241-AP-102 and -104 (the feed staging tanks) leaving a 0.1 ML (10-in.) heel from Batch 2 behind in each tank.

- Homogenize the waste in 241-AW-101 using mixer pumps to resuspend the salt slurry.

- Transfer half of the homogenized waste in 241-AW-101 to 241-AP-102 and the remaining half to $241-\mathrm{AP}-104$, leaving a $0.1 \mathrm{ML}$ (10-in.) heel. During the transfer, the proper amount of diluent will be added to the waste at the transfer pump inlet.

- Mix the waste in 241-AP-102 and mix the waste in 241-AP-104.

- Allow undissolved solids to settle.

The heel remaining in 241-AP-102 and -104 can be neglected for the purposes of this PSDQO; how clean the staging tank needs to be is an operational issue, not a "Confirm Tank T..." issue. Furthermore, diluted Batch 2 waste will be within Envelope A specifications, and mixing wastes from different tanks/batches within the defined specifications should not have an adverse effect on operations.

Define the waste that applies to each element in the decision rule.

Element 1, Dilution Ratio and Diluent Composition: this applies to the whole tank composite (WTC) of 241-AW-101 from 25 to $65^{\circ} \mathrm{C}$.

Element 2, Transfer Requirements: there are two nearly identical transfers; they will be treated as one transfer. Transfer requirements apply to a whole tank composite of the waste currently in 241-AW-101 after addition of the proper amount of diluent over the temperature range of 25 to $65^{\circ} \mathrm{C}$.

Element 3, Mixing Requirements: the mixing requirement applies to a salt slurry composite of the waste currently in 241-AW-101 from 25 to $65^{\circ} \mathrm{C}$. 
Element 4, Envelope Requirements: there is one unique Batch 3 composition; the composition and physical properties are that of a whole tank composite of the waste currently in 241-AW-101 after addition of the proper amount of diluent over the temperature range of 25 to $65^{\circ} \mathrm{C}$. The heel in 241-AP-102 and -104 can be neglected for the purposes of this PSDQO (all current data strongly indicate that the 241-AP-102 and -104 heel will not interfere with staging the compositionally correct feed, because the heel will already be within Envelope A specifications); how clean the tank needs to be is an operational issue, not a "Confirm Tank $\mathrm{T}$..." issue.

Element 5, Miscellaneous Inputs: These inputs apply to the whole tank composition of 241-AW-101 or to changes in the operating scenario that may be imposed in the future.

\section{Evaluate existing data and determine information needs.}

Table 1 contains the evaluation of the base case operating scenario for all the elements of the decision rules found in Section 6 of the PSDQO. The table lists each element taken from Section 6.1 of the PSDQO. For each element, the requirements specific to 241-AW-101 / Batch 3 are listed. Each requirement is evaluated against existing data and the remaining information needs are identified. The information needs are summarized in Table 3. ,

\subsection{ALTERNATIVE CASE OPERATING SCENARIO}

\section{Translate the operating scenario into a series of process steps.}

The TWRSO\&UP (Kirkbride et al. 1997) recommended that process control issues be taken into account. This alternative case operating scenario was developed based on consideration of process control issues and is currently being evaluated and incorporated into the project master baseline schedule and corresponding logic diagrams. The steps that directly. affect the composition of Batch 3 are listed below:

- Empty 241-AP-102 and -104 (the feed staging tanks) leaving a 0.1 ML (10-in.) heel from Batch 2 behind in each tank.

- Decant the supernate in 241-AW-101; transfer half of the supernate to 241-AP-102 and the remainder to 241-AP-104, leaving a 10-in. heel above the salt slurry. During these transfers diluent will be added to the waste at the pump inlet.

- Add diluent to the salt slurry in 241-AW-101 and mix.

- Allow undissolved solids to settle in 241-AW-101.

- Transfer half of the liquid in 241-AW-101 to 241-AP-102 and the remaining to 241-AP-104, leaving a 10-in. heel. No additional diluent is expected to be needed for the transfer. 
- Mix the waste in 241-AP-102 and mix the waste in 241-AP-104.

- Allow any undissolved solids that were inadvertently entrained to settle in 241-AP-102 and -104.

The Batch 2 heel in 241-AP-102 and -104 can be neglected for the purposes of this PSDQO; how clean the tank needs to be is an operational issue, not a "Confirm Tank T..." issue.

Define the waste that applies to each element in the decision rule.

Element 1, Dilution Ratio and Diluent Composition: this applies to both (a) a supernate composite from 241-AW-101 and (b) a salt slurry composite from 241-AW-101, over the temperature range of 25 to $65^{\circ} \mathrm{C}$.

Element 2, Transfer Requirements: out of four transfers, there are two distinct transfers. The transfer requirements applies to (a) supernate composite from $241-\mathrm{AW}-101$ after addition of the proper amount of diluent and (b) a salt sluriy composite from 241-AW-101 after addition of the proper amount of diluent and settling of undissolved solids over the temperature range of 25 to $65^{\circ} \mathrm{C}$.

Element 3, Dissolution Requirements: the dissolution requirements applies to the salt slurry composite of the waste currently in 241-AW-101 over the temperature range of 25 to $65{ }^{\circ} \mathrm{C}$.

Element 4, Envelope Requirements: there is one unique Batch 3 composition; the composition and physical properties are that of a blended tank composite of the waste currently in 241-AW-101, after addition of the proper amount of diluent over the temperature range of 25 to $65^{\circ} \mathrm{C}$ for both the supernatant and salt slurry composites.

The Batch 2 heel in 241-AP-102 and -104 can be neglected for the purposes of this PSDQO (all current data strongly indicate that 241-AP-102 and -104 heel will not interfere with staging the compositionally correct feed because the heel will already be within Envelope A specifications); how clean the tank needs to be is an operational issue, not a "Confirm Tank T..." issue.

Element 5, Miscellaneous Inputs: these inputs apply to the supernatant and salt slurry composition of 241-AW-101 or to changes in the operating scenario that may be imposed in the future. 
HNF-2799

Revision 0

Evaluate existing data and determine information needs.

Table 2 contains the evaluation of the alternative case operating scenario for all the elements of the decision rule found in Section 6 of the PSDQO for Confirm Tank T. The table lists each element of the decision rule taken from Section 6.1 of the PSDQO. For each element, the requirements specific to 241-AW-101 / Batch 3 are listed. Each requirement is evaluated against existing data and remaining information needs are identified. The information needs are developed more fully in Table 3. 
Table 1. Base Case Operating Scenario Evaluation. (6 Sheets)

\begin{tabular}{|c|c|c|c|}
\hline Elements ${ }^{\mathrm{a}}$ & Requirements ${ }^{\mathbf{b}}$ & Discussion/evaluation & Information needs \\
\hline $\begin{array}{l}\text { Element } 1, \text { Dilution } \\
\text { Ratio and Diluent } \\
\text { Composition }\end{array}$ & $\begin{array}{l}\text { Determine the desired dilution ratio } \\
\text { and diluent composition for each } \\
\text { waste transfer. }\end{array}$ & $\begin{array}{l}\text { A process test is being performed in accordance with a test plan } \\
\text { (Herting 1998). The test plan is based on instruction provided by } \\
\text { the Disposal Program (Garfield 1997). The whole tank composite } \\
\text { (WTC) results of this test apply to the Base case operating scenario. } \\
\text { Dilution ratio and Diluent composition will be established. }\end{array}$ & $\begin{array}{l}\text { Desired dilution ratio } \\
\text { and diluent } \\
\text { composition (See } \\
\text { Table 3, Item \# 1). }\end{array}$ \\
\hline \multirow[t]{3}{*}{$\begin{array}{l}\text { Element } 2 \text {, Transfer } \\
\text { Requirements }\end{array}$} & $\begin{array}{l}\text { Confirm that the as-retrieved waste } \\
\text { (including dilution water or caustic) } \\
\text { remains below saturation in major } \\
\text { Na salts during the transfer to the } \\
\text { staging tank. }\end{array}$ & $\begin{array}{l}\text { The composition will be evaluated to determine if it is similar to } \\
\text { previously evaluated tanks. The base case dilution ratio is } \\
\text { assumed to be } 50 \% \text { (by volume). If it is not, the planned process } \\
\text { test performed in accordance with the current test plan (Herting } \\
\text { 1998) will quantify a more appropriate value. }\end{array}$ & $\begin{array}{l}\text { Confirm a dilution } \\
\text { ratio of } 50 \% \text { (by } \\
\text { volume) for the WTC } \\
\text { is below saturation in } \\
\text { major Na salts (See } \\
\text { Table 3, Item \# 2). }\end{array}$ \\
\hline & $\begin{array}{l}\text { Confirm that the as-retrieved waste } \\
\text { (including dilution water or caustic) } \\
\text { remain at or below viscosity of } \\
10 \mathrm{cP} \text {, at or below a } 1.5 \mathrm{SpG} \text {, and at } \\
\text { or below } 30 \text { percent solids by } \\
\text { volume during the transfer to the } \\
\text { staging tank. }\end{array}$ & $\begin{array}{l}\text { A process test is being performed in accordance with a test plan } \\
\text { (Herting 1998). The test will determine viscosity of the undiluted } \\
\text { WTC and at a } 50 \% \text { dilution ratio over the temperatures of } 25,45 \text {, } \\
\text { and } 65^{\circ} \mathrm{C} \text {. } \\
\text { A process test is being performed in accordance with a test plan } \\
\text { (Herting 1998). The largest observed quantity of settled solids for } \\
\text { WTC dilution of } 50 \% \text { at temperatures of } 25,45 \text {, and } 65^{\circ} \mathrm{C} \text { at } 48 \\
\text { hours after mixing will be determined. } \\
\text { A process test is being performed in accordance with a test plan } \\
\text { (Herting 1998). The test will determine the liquid phase density for } \\
\text { WTC dilution of } 50 \% \text { performed at temperatures of } 25,45 \text {, and } 65 \\
{ }^{\circ} \mathrm{C} \text {. }\end{array}$ & $\begin{array}{l}\text { Determine viscosity, } \\
\text { SpG, suspended } \\
\text { solids (See Table 3, } \\
\text { Item \# 3). }\end{array}$ \\
\hline & $\begin{array}{l}\text { Confirm that the dilution ratio, } \\
\text { diluent composition, and waste } \\
\text { composition are balanced so gibbsite } \\
\text { or high viscosity slurries do not } \\
\text { precipitate }\end{array}$ & $\begin{array}{l}\text { An extended storage (at least one month) of supernate sub-samples } \\
\text { from the WTC dilution test at temperatures of } 25,45 \text {, and } 65^{\circ} \mathrm{C} \\
\text { will be observed for solid formation. } \\
\text { Special Consideration: If gibbsite will form, it should form within } \\
\text { four weeks. }\end{array}$ & $\begin{array}{l}\text { Determine solid } \\
\text { formation, if any (See } \\
\text { Table 3, Item \# 4). }\end{array}$ \\
\hline
\end{tabular}


Table 1. Base Case Operating Scenario Evaluation. (6 Sheets)

\begin{tabular}{|c|c|c|c|}
\hline Elements $^{\mathrm{a}}$ & Requirements ${ }^{b}$ & Discussion/evaluation & Information needs \\
\hline \multirow[t]{3}{*}{$\begin{array}{l}\text { Element 3, Mixing } \\
\text { Requirements }\end{array}$} & $\begin{array}{l}\text { Confirm that the portion of the solids } \\
\text { thought to be soluble are soluble and } \\
\text { that they dissolve in a reasonable } \\
\text { amount of time. }\end{array}$ & $\begin{array}{l}\text { The base case operating scenario (Kirkbride et al. 1997) assumed } \\
\text { that the majority of the solids in } 241-\mathrm{AW}-101 \text { would dissolve. A } \\
\text { process test is being performed in accordance with a test plan } \\
\text { (Herting 1998). Amount of undissolved solids is being determined } \\
\text { at } 50 \% \text { dilution for temperature of } 45^{\circ} \mathrm{C} \text {. During the test, } \\
\text { amount of time needed to dissolve the sample will be recorded }\end{array}$ & $\begin{array}{l}\text { Amount of } \\
\text { undissolved solids } \\
\text { and the amount of } \\
\text { time needed to } \\
\text { dissolve the solids } \\
\text { (See Table } 3 \text {, } \\
\text { Item \# 5). }\end{array}$ \\
\hline & $\begin{array}{l}\text { Confirm that the undissolved solids } \\
\text { settle and that they settle in a } \\
\text { reasonable amount of time. }\end{array}$ & $\begin{array}{l}\text { A process test is being performed to determine settling rate for the } \\
\text { undissolved solids. } \\
\text { Scale-up calculations for Herting's settling data have not been } \\
\text { performed. } \\
\text { The base case time allocated in the TWRSO\&UP (Kirkbride et al. } \\
\text { 1997, Assumption 6.11) for settling is taken by reference from } \\
\text { (Certa et al. 1996) and is } 30 \text { days. }\end{array}$ & $\begin{array}{l}\text { Settling rate for the } \\
\text { undissolved solids. } \\
\text { Estimated time to } \\
\text { settle undissolved } \\
\text { solids at full scale. } \\
\text { (See Table } 3 \text {, } \\
\text { Item \# 6). }\end{array}$ \\
\hline & $\begin{array}{l}\text { Confirm that the baseline retrieval } \\
\text { equipment that will be used to } \\
\text { mobilize and transfer the waste is } \\
\text { consistent with the operating } \\
\text { scenario. }\end{array}$ & $\begin{array}{l}\text { Tank 241-AW-101 contains about } 30 \% \text { by weight of a salt slurry. } \\
\text { (Field et al. 1998). The base case operating scenario targets most } \\
\text { of the sodium in the salt slurry for feed. The equipment required to } \\
\text { mobilize and retrieve the slurry includes mixer pumps and a } \\
\text { transfer pump with water (and caustic) dilution capability (Boston } \\
\text { 1997). This is consistent with the equipment identified in the base } \\
\text { case operating scenario (Kirkbride et al. 1997). } \\
\text { Retrieval equipment to be added to } 241-\text { AW-101 will accomplish } \\
\text { requirements. }\end{array}$ & $\begin{array}{l}\text { No further } \\
\text { information is } \\
\text { needed. }\end{array}$ \\
\hline
\end{tabular}


Table 1. Base Case Operating Scenario Evaluation. (6 Sheets)

\begin{tabular}{|c|c|c|c|}
\hline Elements $^{\mathrm{a}}$ & Requirements ${ }^{\mathbf{b}}$ & Discussion/evaluation & Information needs \\
\hline \multirow[t]{3}{*}{$\begin{array}{l}\text { Element } 4 \text { - Part } 1 \text { : } \\
\text { Envelope } \\
\text { Requirements } \\
\text { These limits apply to } \\
\text { the feed actually } \\
\text { delivered to the } \\
\text { private contractors. }\end{array}$} & $\begin{array}{l}\text { Concentration limits for the chemical } \\
\text { and radionuclide content of the feed } \\
\text { (DOE-RL 1996, Section C.6). } \\
\text { See Section } 2.0 \text {, Tables } 1 \text { and } 2 \text { (in } \\
\text { main report) for the limits. }\end{array}$ & $\begin{array}{l}\text { Only Envelope A limits apply to Batch } 3 \text {. } \\
\text { The TWRSO\&UP (Kirkbride et al. 1997, Tables I-1 and I-3)) } \\
\text { compared the point estimates }{ }^{1} \text { of the composition of the feed from } \\
241-A W-101 \text { to the Envelope A limits. All analytes were below } \\
80 \% \text { of their maximum limits. }\end{array}$ & $\begin{array}{l}\text { Chemical and } \\
\text { radionuclide analyses } \\
\text { from Herting's tests } \\
\text { (See Table 3, } \\
\text { Item \# 7). } \\
\text { A statistical } \\
\text { evaluation of the data } \\
\text { from 241-AW-101 is } \\
\text { required to evaluate } \\
\text { envelope limits } \\
\text { (Table 3, Item \#16) }\end{array}$ \\
\hline & $\begin{array}{l}\text { Concentration limit for the sodium } \\
\text { concentration of the feed: } \\
3 \underline{M} \leq[\mathrm{Na}] \leq 14 \mathrm{M} \text { (DOE-RL } \\
1996 \text {, Section C.6). }\end{array}$ & During Herting's process test [Na] will be measured. & $\begin{array}{l}\text { [Na] measurement } \\
\text { (See Table 3, } \\
\text { Item \# 8). }\end{array}$ \\
\hline & $\begin{array}{l}\text { Insoluble solids fraction limit will } \\
\text { not exceed } 5 \text { volume \% (DOE-RL } \\
\text { 1996, Section C.6). }\end{array}$ & $\begin{array}{l}\text { The contracts do not define how the volume percent insoluble solids } \\
\text { will be measured. } \\
\text { Herting (1998) will measure the quantity of solids for WTC dilution } \\
\text { of } 50 \% \text { at temperature of } 45^{\circ} \mathrm{C} \text {. }\end{array}$ & $\begin{array}{l}\text { Insoluble solids } \\
\text { measurement (See } \\
\text { Table 3, Item \# 9). } \\
\end{array}$ \\
\hline
\end{tabular}

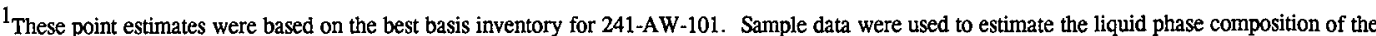
diluted waste. 
Table 1. Base Case Operating Scenario Evaluation. (6 Sheets)

\begin{tabular}{|c|c|c|c|}
\hline Elements $^{a}$ & Requirements ${ }^{\mathbf{b}}$ & Discussion/evaluation & Information needs \\
\hline \multirow[t]{2}{*}{$\begin{array}{l}\text { Element } 4 \text { - Part 1: } \\
\text { Envelope } \\
\text { Requirements } \\
\text { (continued) } \\
\text { These limits apply to } \\
\text { the feed actually } \\
\text { delivered to the } \\
\text { private contractors. }\end{array}$} & $\begin{array}{l}\text { Operating Specifications from } \\
\text { OSD-T-151-00007 (DOE-RL } 1996 \text {, } \\
\text { Section C. } 6 \text { invokes the OSD by } \\
\text { reference). } \\
\text { See Section } 2.0 \text {, Tables } 3 \text { (in main } \\
\text { report). }\end{array}$ & $\begin{array}{l}\text { The contract does not explicitly state which specifications from the } \\
\text { OSD apply to the waste. The PHMC assumes that the Tank } \\
\text { Composition (7.2.1) and Heat Generation Rate (7.2.8) limits apply } \\
\text { to the waste. These limits are shown in Section } 2.0 \text {, Table } 3 \text { (in } \\
\text { main report). } \\
\text { The TWRSO\&UP (Kirkbride et al. } 1997 \text {, Section } 3.1 .1 .6 \text { ) } \\
\text { compared the point estimates of the composition of the waste as } \\
\text { staged in } 241-A P-102 \text { and }-104 \text { with the Tank Composition (Tank } \\
\text { Corrosion) specifications. All limits were satisfied for Batch } 3 \text {. } \\
\left.\text { Uncertainty is not an issue since the [OH], [NO }{ }_{2}\right] \text { and }\left[\mathrm{NO}_{3}\right] \text { in the } \\
\text { staging tanks can be adjusted if needed before the feed qualification } \\
\text { samples are taken. } \\
\text { The TwRSO\&UP (Section } 3.1 .1 .6 \text { ) also evaluated the heat } \\
\text { generation rate rule and found that all limits were satisfied for } \\
\text { Batch } 3, \text { decayed to the estimated time of delivery. The estimated } \\
\text { total heat generation rate for Batch } 3 \text { from Field et al. (1998) is } \\
33,200 \mathrm{BTU} / \mathrm{hr} \text {. This estimate is conservative since it does not take } \\
\text { into account the additional decay that will take place before } \\
\text { delivery of the feed Batch. This value is well within the maximum } \\
\text { limit of } 70,000 \text { BTU/hr. } \\
\text { Conformance with OSD factors achieved. }\end{array}$ & $\begin{array}{l}\text { No further } \\
\text { information is } \\
\text { needed. }\end{array}$ \\
\hline & $\begin{array}{l}\text { Maximum }{ }^{137} \mathrm{Cs} \text { concentration of } \\
5.86 \mathrm{E} 10 \mathrm{~Bq} / \mathrm{liter}(6 \mathrm{Ci} / \mathrm{gal}) \text {. }\end{array}$ & $\begin{array}{l}\text { This limit is equivalent to } 1.59 \mathrm{E}+06 \mu \mathrm{Ci} / \mathrm{L} \text {. The OSD limit of } \\
5.74 \mathrm{E}+05 \mu \mathrm{Ci} / \mathrm{L} \text { is more restrictive. } \\
\text { Using the best basis inventory and reported volume for } \\
241-\mathrm{AW}-101 \text { from Field et al. ( } 1998) \text {, the bulk }\left[{ }^{137} \mathrm{Cs}\right] \text { is calculated } \\
\text { to be } 4.63 \mathrm{E}+05 \mu \mathrm{Ci} / \mathrm{L} \text { and }\left[{ }^{90} \mathrm{Sr}\right] \text { is } 1.26 \mathrm{E}+03 \mu \mathrm{Ci} / \mathrm{L} \text {. These are } \\
\text { both well below the OSD limits of } 5.74 \mathrm{E}+05 \mu \mathrm{Ci} / \mathrm{L} \text { and } 4.04 \mathrm{E}+05 \\
\mu \mathrm{Ci} / \mathrm{L} \text {, respectively. This is a conservative comparison since the } \\
\text { dilution has not been accounted for in the above estimates. } \\
\text { Conformance with maximum }{ }^{137} \mathrm{Cs} \text { concentration achieved. }\end{array}$ & $\begin{array}{l}\text { No further } \\
\text { information is } \\
\text { needed. }\end{array}$ \\
\hline
\end{tabular}


Table 1. Base Case Operating Scenario Evaluation. (6 Sheets)

\begin{tabular}{|c|c|c|c|}
\hline Elements $^{\mathrm{a}}$ & Requirements ${ }^{\mathrm{b}}$ & Discussion/evaluation & Information needs \\
\hline $\begin{array}{l}\text { Element } 4 \text { - Part 1: } \\
\text { Envelope } \\
\text { Requirements } \\
\text { (continued) }\end{array}$ & $\begin{array}{l}\text { The PHMC assumed minimum limits } \\
\text { to distinguish between Envelope A } \\
\text { and } C \text { and between Envelopes } A \\
\text { and } B\end{array}$ & $\begin{array}{l}\text { These discriminators do not apply to Batch } 3 \text { (Envelope A). } \\
\text { No concern about distinguishing between envelopes. }\end{array}$ & $\begin{array}{l}\text { No further } \\
\text { information is } \\
\text { needed. }\end{array}$ \\
\hline \multirow[t]{3}{*}{$\begin{array}{l}\text { Element } 4 \text { - Part } 2 \text { : } \\
\text { Quantity } \\
\text { Requirements }\end{array}$} & $\begin{array}{l}\text { Batch size (mass of sodium) } \\
\text { constraints (from the contracts) } 2 \\
100 \mathrm{MT} \mathrm{Na} \text {. }\end{array}$ & $\begin{array}{l}\text { Field et al. (1998) estimates the total sodium present in } \\
241-\mathrm{AW}-10 \mathrm{i} \text { to be approximately } 1,070 \mathrm{MT} \text {. During Herting's } \\
\text { process test, amount of Na recoverable will be measured at the } \\
\text { quantified dilution ratio, or using the base case } 50 \% \text { dilution. }\end{array}$ & $\begin{array}{l}\text { Determine } \mathrm{Na} \\
\text { quantity (See Table } 3 \text {, } \\
\text { Item \# 10). }\end{array}$ \\
\hline & $\begin{array}{l}\text { PHMC targeted batch size range } \\
\text { (from the ICD (PHMC 1997, } \\
\text { Table 3D): } 250 \text { - } 600 \text { MT Na. }\end{array}$ & Same as above. & $\begin{array}{l}\text { Determine } \mathrm{Na} \\
\text { quantity (See Table } 3 \text {, } \\
\text { Item \# 10). }\end{array}$ \\
\hline & $\begin{array}{l}\text { PHMC desired batch size (from } \\
\text { Operating Scenario): } 535 \text { MT Na } \\
\text { (Kirkbride et al. } 1997 \text {, Table } 3.1-5 \text { ) }\end{array}$ & Same as above. & $\begin{array}{l}\text { Determine } \mathrm{Na} \\
\text { quantity (See Table } 3 \text {, } \\
\text { Item } \# \mathbf{1 0} \text { ). }\end{array}$ \\
\hline \multirow[t]{4}{*}{$\begin{array}{l}\text { Element } 5 \text { - } \\
\text { Miscellaneous Inputs }\end{array}$} & Physical form of Tank T contents & $\begin{array}{l}\text { From Field et al (1998): } 241-\mathrm{AW}-101 \text { has approximately } 7.6 \mathrm{~m} \\
\text { ( } 24.8 \mathrm{ft} \text { ) of supernate which is compositionally homogenous. There } \\
\text { is an irregular crust volume, however it is anticipated that the crust } \\
\text { will dissolve during dilution. There are approximately } 2.8 \mathrm{~m}(9.3 \\
\mathrm{ft} \text { ) of settled solids. There is no hard pan. }\end{array}$ & $\begin{array}{l}\text { No further } \\
\text { information is needed }\end{array}$ \\
\hline & $\begin{array}{l}\text { Heel from prior batch remaining in } \\
\text { staging tanks }\end{array}$ & $\begin{array}{l}\text { Heels remaining in } 241-\mathrm{AP}-102 \text { and }-104 \text { from previous batches are } \\
\text { addressed in Section } 2.1 \text { above. }\end{array}$ & $\begin{array}{l}\text { No further } \\
\text { information is needed }\end{array}$ \\
\hline & Shimming Batch 3 & No shimming is anticipated. & $\begin{array}{l}\text { No further } \\
\text { information is needed }\end{array}$ \\
\hline & RL direction & $\begin{array}{l}\text { No changes to applicable M\&I ICD requirements have been made } \\
\text { to date. }\end{array}$ & $\begin{array}{l}\text { No further } \\
\text { information is needed }\end{array}$ \\
\hline
\end{tabular}

a. Elements are taken from the Decision Rule statement in Section 6.1 of PSDQO-01.

b. Requirements are taken from Sections 4.1, 4.2, 4.3, 4.4, and 4.5 of PSDQO-01. 
HNF-2799

Revision 0

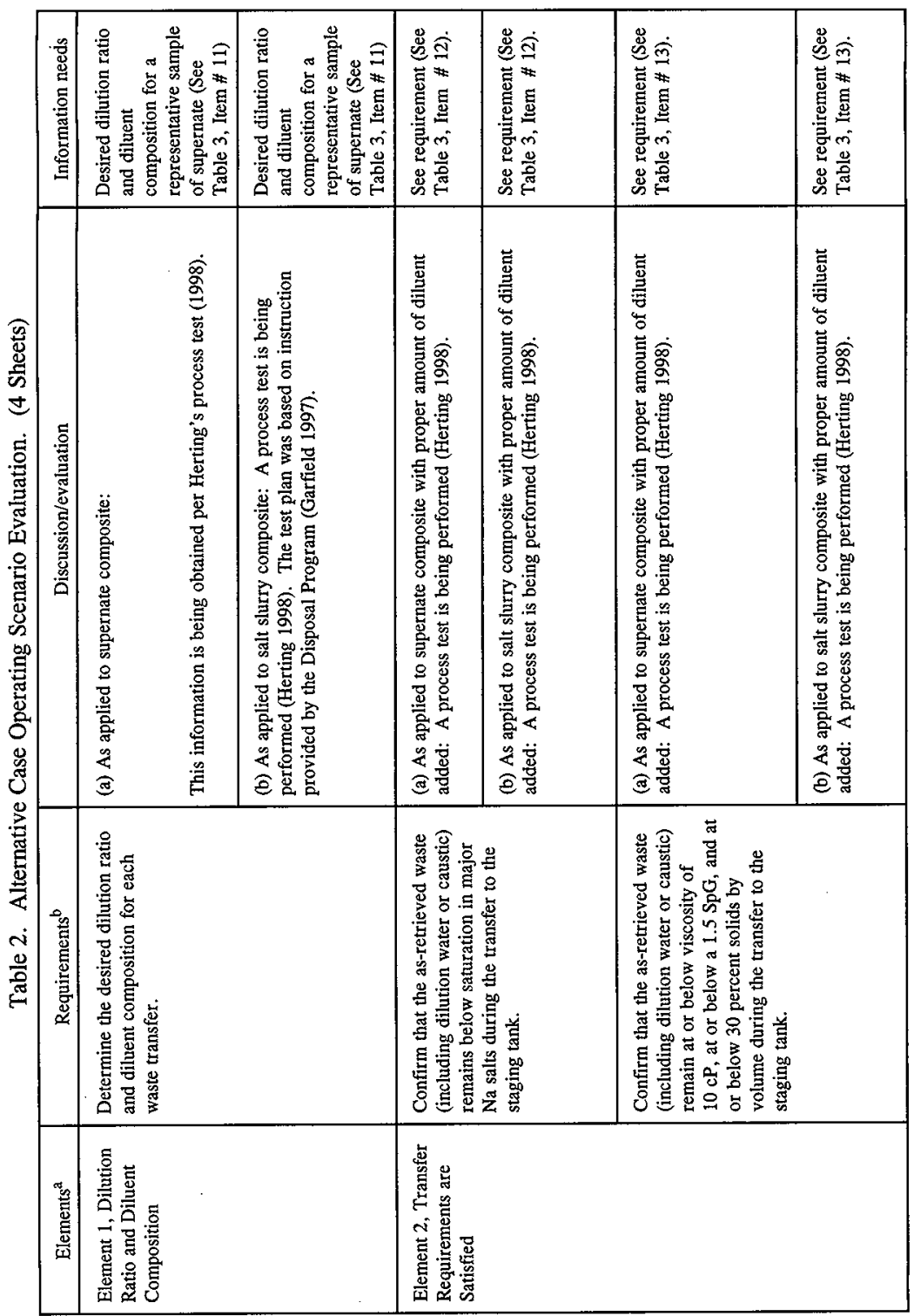


Table 2. Alternative Case Operating Scenario Evaluation. (4 Sheets)

\begin{tabular}{|c|c|c|c|}
\hline Elements ${ }^{\mathrm{a}}$ & Requirements $^{\mathrm{b}}$ & Discussion/evaluation & Information needs \\
\hline $\begin{array}{l}\text { Element 2, Transfer } \\
\text { Requirements are } \\
\text { Satisfied (continued) }\end{array}$ & $\begin{array}{l}\text { Confirm that the dilution ratio, } \\
\text { diluent composition, and waste } \\
\text { composition are balanced so gibbsite } \\
\text { or high viscosity slurries do not } \\
\text { precipitate. }\end{array}$ & A process test is being performed (Herting 1998). & $\begin{array}{l}\text { Precipitation at } 0,40, \\
80 \text {, and } 120 \% \\
\text { dilution (See Table 3, } \\
\text { Item \# 14). }\end{array}$ \\
\hline \multirow[t]{3}{*}{$\begin{array}{l}\text { Element } 3, \\
\text { Dissolution } \\
\text { Requirements }\end{array}$} & $\begin{array}{l}\text { Confirm that the portion of the } \\
\text { solids thought to be soluble are } \\
\text { soluble and that they dissolve in a } \\
\text { reasonable amount of time. }\end{array}$ & $\begin{array}{l}\text { The Base case operating scenario (Kirkbride et al. 1997) assumed that } \\
\text { the majority of the solids in } 241 \text {-AW-101 would dissolve. } \\
\text { A process test is being performed (Herting 1998). }\end{array}$ & $\begin{array}{l}\text { Amount of soluble } \\
\text { solids and amount of } \\
\text { time required to } \\
\text { dissolve soluble solids } \\
\text { (See Table } 3 \text {, } \\
\text { Item \# 15). }\end{array}$ \\
\hline & $\begin{array}{l}\text { Confirm that the undissolved solids } \\
\text { settle and that they settle in a } \\
\text { reasonable amount of time. }\end{array}$ & $\begin{array}{l}\text { A process test is being performed to determine settling rate for the } \\
\text { undissolved solids. } \\
\text { Scale-up calculations for Herting's settling data have not been } \\
\text { performed. }\end{array}$ & $\begin{array}{l}\text { Settling rate for the } \\
\text { undissolved solids. } \\
\text { Estimated time to } \\
\text { settle undissolved } \\
\text { solids at full scale } \\
\text { (See Table 3, } \\
\text { Item \#14). }\end{array}$ \\
\hline & $\begin{array}{l}\text { Confirm that the baseline retrieval } \\
\text { equipment that will be used to } \\
\text { mobilize and transfer the waste is } \\
\text { consistent with the operating } \\
\text { scenario. }\end{array}$ & $\begin{array}{l}\text { The alternative case uses the same retrieval equipment as the base case. } \\
\text { See base case evaluation for details. } \\
\text { Retrieval equipment to be added to AW-101 will accomplish } \\
\text { requirements. }\end{array}$ & $\begin{array}{l}\text { No further } \\
\text { information is } \\
\text { needed. }\end{array}$ \\
\hline $\begin{array}{l}\text { Element } 4 \text { - Part } 1 \text { : } \\
\text { Envelope } \\
\text { Requirements } \\
\text { These limits apply to } \\
\text { the feed actually } \\
\text { delivered to the } \\
\text { private contractors. }\end{array}$ & $\begin{array}{l}\text { Concentration limits for the } \\
\text { chemical and radionuclide content of } \\
\text { the feed (DOE-RL 1996, } \\
\text { Section C.6). } \\
\text { See Section 2.0, Tables } 1 \text { and } 2 \text { (in } \\
\text { main report) for the limits. }\end{array}$ & $\begin{array}{l}\text { Only Envelope A limits apply to Batch } 3 \text {. } \\
\text { In the alternative case, the composition of the waste staged in } \\
241-\mathrm{AP}-102 \text { and }-104 \text { is almost identical to that of the base case. There } \\
\text { will be differences in absolute concentration due to differences in the } \\
\text { total amount of dilution, but this will not affect the [analyte]:[Na] } \\
\text { values. There will also be differences due to slightly different extent of } \\
\text { solids dissolution, but these will be bounded by the proposed statistical } \\
\text { evaluation for the base case. }\end{array}$ & $\begin{array}{l}\text { Chemical and } \\
\text { radionuclide analyses } \\
\text { from Herting's tests } \\
\text { (See Table } 3 \text {, } \\
\text { Items \# } 7 \text { and \#16). }\end{array}$ \\
\hline
\end{tabular}


Table 2. Alternative Case Operating Scenario Evaluation. (4 Sheets)

\begin{tabular}{|c|c|c|c|}
\hline Elements $^{\mathrm{a}}$ & Requirements $^{b}$ & Discussion/evaluation & Information needs \\
\hline \multirow[t]{5}{*}{$\begin{array}{l}\text { Element } 4 \text { - Part 1: } \\
\text { Envelope } \\
\text { Requirements } \\
\text { (Continued) } \\
\text { These limits apply to } \\
\text { the feed actually } \\
\text { delivered to the } \\
\text { private contractors. }\end{array}$} & $\begin{array}{l}\text { Concentration limit for the sodium } \\
\text { concentration of the feed: } \\
3 \mathrm{M} \leq[\mathrm{Na}] \leq 14 \mathrm{M} \text { (DOE-RL } \\
1996 \text {, Section C.6). }\end{array}$ & $\begin{array}{l}\text { Since the supernate dilution ratio was not established, the resulting [Na] } \\
\text { in the Batch cannot be directly determined. A process test is being } \\
\text { performed (Herting 1998). } \\
\text { The sodium concentration for the feed batch can be adjusted in the } \\
\text { intermediate feed staging tanks. } \\
\text { Compliance with Na molarity achieved. }\end{array}$ & $\begin{array}{l}\text { Sodium concentration } \\
\text { values for the } \\
\text { supernate and solids } \\
\text { after dilution must be } \\
\text { established. (Item \#7) } \\
\text { Statistical evaluation } \\
\text { of data is needed. } \\
\text { (Item \#16) }\end{array}$ \\
\hline & $\begin{array}{l}\text { Insoluble solids fraction limit will } \\
\text { not exceed } 5 \text { volume \% (DOE-RL } \\
\text { 1996, Section C.6). }\end{array}$ & $\begin{array}{l}\text { In the alternative case, the only solids that should end up in the feed } \\
\text { batch are those solids that are inadvertently entrained during the decant } \\
\text { transfers. This is an operational issue, not a "Confirm Tank T..." issue. } \\
\text { Compliance with insoluble fraction will be resolved as encountered } \\
\text { during operations. }\end{array}$ & $\begin{array}{l}\text { No further } \\
\text { information is } \\
\text { needed. }\end{array}$ \\
\hline & $\begin{array}{l}\text { Operating Specifications from } \\
\text { OSD-T-151-00007 (DOE-RL } 1996 \text {, } \\
\text { Section C. } 6 \text { invokes the OSD by } \\
\text { reference). } \\
\text { See Section } 2.0 \text {, Table } 3 \text { (in main } \\
\text { report). }\end{array}$ & $\begin{array}{l}\text { Mass balances have not been performed on the alternative case } \\
\text { operating scenario to estimate the composition of the staged feed batch } \\
\text { (these can be done explicitly after the supernate dilution ratio has been } \\
\text { determined. Bounding calculations can be performed, however it is } \\
\text { simpler to wait for the dilution ratio. }\end{array}$ & $\begin{array}{l}\text { Estimated } \\
\text { composition of the } \\
\text { staged feed (See } \\
\text { Table 3, Item \# 17). }\end{array}$ \\
\hline & $\begin{array}{l}\text { Maximum }{ }^{137} \mathrm{Cs} \text { concentration of } \\
5.86 \mathrm{E} 10 \mathrm{~Bq} / \text { liter }(6 \mathrm{Ci} / \mathrm{gal}) \text {. }\end{array}$ & $\begin{array}{l}\text { This limit is equivalent to } 1.59 \mathrm{E}+06 \mu \mathrm{Ci} / \mathrm{L} \text {. } \\
\text { Using the best basis inventory and reported volume for } 241-\mathrm{AW}-101 \\
\text { from Field et al. (1998), the bulk }\left[{ }^{137} \mathrm{Cs} \text { ] is calculated to be } 4.63 \mathrm{E}+05\right. \\
\mu \mathrm{Ci} / \mathrm{L} \text {. This is well below the } \mathrm{OSD} \text { limit of } 1.59 \mathrm{E}+06 \mu \mathrm{Ci} / \mathrm{L} \text {. This is } \\
\text { a conservative comparison since dilution has not been included. } \\
\text { Conformance with maximum }{ }^{137} \mathrm{Cs} \text { achieved. }\end{array}$ & $\begin{array}{l}\text { No further } \\
\text { information is } \\
\text { needed. }\end{array}$ \\
\hline & $\begin{array}{l}\text { The PHMC assumed minimum } \\
\text { limits to distinguish between } \\
\text { Envelope } \mathrm{A} \text { and } \mathrm{C} \text { and between } \\
\text { Envelopes } \mathrm{A} \text { and } \mathrm{B}\end{array}$ & $\begin{array}{l}\text { These discriminators do not apply to Batch } 3 \text { (Envelope A). } \\
\text { No concern about distinguishing between envelopes. }\end{array}$ & $\begin{array}{l}\text { No further } \\
\text { information is } \\
\text { needed. }\end{array}$ \\
\hline
\end{tabular}


Table 2. Alternative Case Operating Scenario Evaluation. (4 Sheets)

\begin{tabular}{|c|c|c|c|}
\hline Elements $^{\mathrm{a}}$ & Requirements $^{\mathrm{b}}$ & Discussion/evaluation & Information needs \\
\hline \multirow{3}{*}{$\begin{array}{l}\text { Element } 4 \text { - Part 2: } \\
\text { Quantity } \\
\text { Requirements are } \\
\text { Satisfied }\end{array}$} & $\begin{array}{l}\text { Batch size (mass of sodium) } \\
\text { constraints (from the contracts) z } \\
100 \text { MT Na. }\end{array}$ & $\begin{array}{l}\text { Field et al. (1998) estimates the total sodium present in } \\
241-\mathrm{AW}-101 \text { to be approximately } 1,070 \mathrm{MT} \text {. During Herting's process } \\
\text { test, amount of Na recoverable will be measured. }\end{array}$ & $\begin{array}{l}\text { Determine } \mathrm{Na} \\
\text { quantity (See Table } 3 \text {, } \\
\text { Item } \# 10 \text { ). }\end{array}$ \\
\hline & $\begin{array}{l}\text { PHMC targeted batch size range } \\
\text { (from the ICD (PHMC 1997, } \\
\text { Table 3D): } 250 \text { - } 600 \mathrm{MT} \mathrm{Na} \text {. }\end{array}$ & Same as above. & $\begin{array}{l}\text { No further } \\
\text { information is } \\
\text { needed. }\end{array}$ \\
\hline & $\begin{array}{l}\text { PHMC desired batch size (from } \\
\text { Operating Scenario): } 535 \text { MT Na } \\
\text { (Kirkbride et al. 1997, Table 3.1-5) }\end{array}$ & $\begin{array}{l}\text { Same as above. } \\
\text { Na quantity will be resolved administratively or by shimming. }\end{array}$ & $\begin{array}{l}\text { No further } \\
\text { information is } \\
\text { needed. }\end{array}$ \\
\hline \multirow[t]{4}{*}{$\begin{array}{l}\text { Element } 5 \text { - } \\
\text { Miscellaneous Inputs }\end{array}$} & Physical form of Tank $T$ contents & $\begin{array}{l}\text { From Field et al }(1998): 241-\mathrm{AW}-101 \text { has approximately } 7.6 \mathrm{~m}(24.8 \mathrm{ft}) \\
\text { of supernate which is compositionally homogenous. There are } \\
\text { approximately } 2.8 \mathrm{~m}(9.3 \mathrm{ft}) \text { of settled solids. There is no hard pan. }\end{array}$ & $\begin{array}{l}\text { No further } \\
\text { information is needed }\end{array}$ \\
\hline & $\begin{array}{l}\text { Heel from prior batch remaining in } \\
\text { staging tanks }\end{array}$ & $\begin{array}{l}\text { Heels remaining in } 241-\mathrm{AP}-102 \text { and }-104 \text { from previous batches are } \\
\text { addressed in Section } 2.1 \text { above. }\end{array}$ & $\begin{array}{l}\text { No further } \\
\text { information is needed }\end{array}$ \\
\hline & Shimming Batch 3 & No shimming is anticipated. & $\begin{array}{l}\text { No further } \\
\text { information is needed }\end{array}$ \\
\hline & $\mathrm{RL}$ direction & $\begin{array}{l}\text { No changes to applicable } M \& I \text { ICD requirements have been made to } \\
\text { date. }\end{array}$ & $\begin{array}{l}\text { No further } \\
\text { information is needed }\end{array}$ \\
\hline
\end{tabular}

${ }^{2}$ Elements are taken from the Decision Rule statement in Section 6.1 of PSDQO-01.

${ }^{b}$ Requirements are taken from Sections 4.1, 4.2, 4.3, 4.4, and 4.5 of PSDQO-01. 
Table 3 was developed jointly by TWRS Characterization and Tank Waste Retrieval. It is intended to show what information is still needed, what can be obtained by calculations with existing data, what requires new (or existing) samples, analysis, and/or process testing. Where samples are required, the amount and "representativeness" of the sample will be stated. Where analysis is needed, the specific analytes and QA requirements will be stated. If process testing is needed, the amount of sample and goals of the process test will be stated.

Appropriate level of end description of QA requirements will be covered in the specific work plan for these limited process tests.

Table 3. Information Needs. (2 Sheets)

\begin{tabular}{|l|l|l|l|}
\hline Item & \multicolumn{1}{|c|}{ Information need } & \multicolumn{1}{|c|}{ Pample } \\
\hline 1 & $\begin{array}{l}\text { Desired dilution ratio } \\
\text { and diluent composition }\end{array}$ & A process test is being performed & None \\
\hline 2 & $\begin{array}{l}\text { Confirm a dilution ratio } \\
\text { of 50\% by volume for } \\
\text { the WTC is below } \\
\text { saturation in major Na } \\
\text { salts }\end{array}$ & A process test is being performed & None \\
\hline 3 & $\begin{array}{l}\text { Determine viscosity, } \\
\text { SpG, suspended solids }\end{array}$ & A process test is being performed & None \\
\hline 4 & $\begin{array}{l}\text { Determine solid } \\
\text { formation, if any }\end{array}$ & A process test is being performed & None \\
\hline 5 & $\begin{array}{l}\text { Amount of undissolved } \\
\text { solids and the amount of } \\
\text { time needed to dissolve } \\
\text { the solids }\end{array}$ & A process test is being performed & None \\
\hline 6 & $\begin{array}{l}\text { Estimate time to settle } \\
\text { undissolved solids at full } \\
\text { scale }\end{array}$ & $\begin{array}{l}\text { Engineering calculations: no additional } \\
\text { tests required }\end{array}$ & None \\
\hline 7 & $\begin{array}{l}\text { Chemical and } \\
\text { radionuclide analyses } \\
\text { from Herting's test }\end{array}$ & A process test is being performed & None \\
\hline 8 & [Na] measurement & A process test is being performed & None \\
\hline 9 & $\begin{array}{l}\text { Insoluble solids } \\
\text { measurement }\end{array}$ & A process test is being performed & None \\
\hline 10 & $\begin{array}{l}\text { Determination of Na } \\
\text { quantity }\end{array}$ & A process test is being performed & None \\
\hline
\end{tabular}


HNF-1796

Revision 0

Table 3. Information Needs. (2 Sheets)

\begin{tabular}{|c|c|c|c|}
\hline Item & Information need & Planned resolution & $\begin{array}{l}\text { Sample } \\
\text { required }\end{array}$ \\
\hline 11 & $\begin{array}{l}\text { Desired dilution ratio } \\
\text { and diluent composition } \\
\text { for a representative } \\
\text { sample of supernate. }\end{array}$ & $\begin{array}{l}\text { Calculate from results of Item } \# 12 \text { and } \\
\text { ESP. No additional tests required. }\end{array}$ & None \\
\hline 12 & $\begin{array}{l}\text { Confirm as-retrieved } \\
\text { waste remains below } \\
\text { saturation in major NA } \\
\text { salts during transfer. }\end{array}$ & $\begin{array}{l}\text { Performing lab test: measure \%solids vs. } \\
\text { temp for supernate at } 25,45 \text { and } 65{ }^{\circ} \mathrm{C} \\
\text { under } 3 \text { conditions: undiluted, } 10 \% \\
\text { diluted and } 20 \% \text { diluted. }\end{array}$ & None \\
\hline 13 & $\begin{array}{l}\text { Confirm as-retrieved } \\
\text { waste remains }<10 \mathrm{cP} \text {, } \\
<1.5 \mathrm{SpG} \text {, and }<30 \% \\
\text { solids during transfer. }\end{array}$ & $\begin{array}{l}\text { SpG, viscosity and \%Solids are being } \\
\text { measured. }\end{array}$ & None \\
\hline 14 & $\begin{array}{l}\text { Precipitation at } 0,40, \\
80, \text { and } 120 \% \text { dilutions }\end{array}$ & $\begin{array}{l}\text { Process testing is being performed at these } \\
\text { dilutions. }\end{array}$ & None \\
\hline 15 & $\begin{array}{l}\text { Amount of soluble solids } \\
\text { and amount time needed } \\
\text { to dissolve soluble } \\
\text { solids. }\end{array}$ & A process test is being performed. & None \\
\hline 16 & $\begin{array}{l}\text { Concentrations and } \\
\text { uncertainties for diluted } \\
\text { supernate and solids. }\end{array}$ & $\begin{array}{l}\text { Statistical analysis of data from dilution } \\
\text { studies. }\end{array}$ & None \\
\hline 17 & $\begin{array}{l}\text { Estimate composition of } \\
\text { staged feed. }\end{array}$ & $\begin{array}{l}\text { Can be calculated from existing data after } \\
\text { item } \# 11 \text { is resolved. }\end{array}$ & None \\
\hline
\end{tabular}

There are seventeen items that have been flagged in Tables 1 and 2 requiring further information. All items are being addressed by a specific process test with specific material from 241-AW-101. There are no other information needs requiring either an analysis of an existing 241-AW-101 sample or the collection of additional sample followed by analysis in order to confirm that tank 241-AW-101 is appropriate for Batch 3. 
HNF-1796

Revision 0

\subsection{REFERENCES}

Boston, H. L., 1997, Subcontract Number 80232764-9-K001, Design Basis for Retrieval Equipment in Tanks $A N-104$ and $A N-105$, Letter to A. M. Umek (Fluor Daniel Hanford, Incorporated), LMHC-9758071, Lockheed Martin Hanford Corporation, Richland, Washington.

Certa, P. J., W. H. Grams, C. M. McConville, L. W. Shelton and E. J. Slaathaug, 1996, Low-Level Waste Feed Staging Plan, WHC-SD-WM-RPT-224, Rev. 0, Westinghouse Hanford Company, Richland, Washington.

DOE-RL, 1996, TWRS Privatization, Contract Numbers DE-RP06-96RL13308 and 13309, U.S. Department of Energy, Richland, Washington.

Garfield, J. S., 1997, Tank 241-AN-104 Dilution/Dissolution Test Requirements, internal memo to D. L. Herting, 8C451-97-004 (March 27), Numatec Hanford Corporation, Richland, Washington.

Herting, D. L, 1998, Test Plan for Tank 241-AW-101 Dilution Studies, HNF-2239, Rev. 0, Numatec Hanford Corporation, Richland, Washington.

Field, J. G., C. J. Benar, and S. R. Wilmarth, 1998, Tank Characterization Report for Double-Shell Tank 241-AW-101, HNF-SD-WM-ER-470, Rev. 1, Lockheed Martin Hanford Company, Richland, Washington.

Kirkbride, R. A., G. K. Allen, P. J. Certa, A. F. Manuel, R. M. Orme, L. W. Shelton, E. J. Slaathaug, R. S. Wittman, G. T. MacLean and D. L. Penwell, 1997, Tank Waste Remediation System Operation and Utilization Plan, HNF-SD-WM-SP-012, Rev. OA, Vol. I and II, Numatec Hanford Corporation, Richland, Washington.

PHMC, 1996, Unclassified Operating Specification for the 241-AN, AP, AW, AY, AZ, and SY Tank Farms, OSD-T-151-00007, Rev. H-18, Fluor Daniel Hanford, Richland, Washington.

PHMC, 1997, Interface Control Document Between DOE and the PHMC, Low-Activity Waste Feed, HNF-SP-1223 (ICD-19), Project Hanford Management Contractor, Richland, Washington. 
HNF-2799

Revision 0

\section{ADDENDUM 4}

\section{APPLICATION OF \\ "CONFIRM TANK T IS AN APPROPRIATE FEED SOURCE \\ FOR LOW-ACTIVITY WASTE \\ FEED BATCH $X "$}

TO

241-AN-103 / BATCH 4 
HNF-2799

Revision 0

This page intentionally left blank.

Addendum 4-2 
CONTENTS

1.0 INTRODUCTION $\ldots \ldots \ldots \ldots \ldots \ldots \ldots \ldots$ Addendum $4-5$

2.0 EVALUATION $\ldots \ldots \ldots \ldots \ldots \ldots \ldots \ldots \ldots$ Addendum 4 . 5

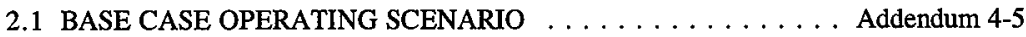

2.2 ALTERNATIVE CASE OPERATING SCENARIO $\ldots \ldots \ldots$. . Addendum 4-6

3.0 REFERENCES $\ldots \ldots \ldots \ldots \ldots \ldots \ldots \ldots \ldots$ Addendum 4 . $20 \ldots \ldots$

\section{LIST OF TABLES}

1. Base Case Operating Scenario Evaluation $\ldots \ldots \ldots \ldots \ldots$ Addendum $4-9$

2. Alternative Case Operating Scenario Evaluation $\ldots \ldots \ldots \ldots \ldots$ Addendum 4-14

3. Information Needs $\ldots \ldots \ldots \ldots \ldots \ldots \ldots \ldots \ldots \ldots \ldots \ldots \ldots \ldots$ Addendum $4-18$ 
HNF-2799

Revision 0

\section{LIST OF TERMS}

DOE U.S. Department of Energy

ICD Interface Control Document

LAW Low-Activity Waste

M Molar (gmoles/liter)

PHMC Project Hanford Management Contract(or)

PMBS Project Master Baseline Schedule

PSDQO Problem-Specific Data Quality Objectives

RL U.S. Department of Energy-Richland Operations

TANK T Refers to the contents from one tank, multiple tanks, or portions of one or more tanks that will be used to prepare a feed batch

TOC Total Organic Carbon

TWRS Tank Waste Remediation System

TWRSO\&UP Tank Waste Remediation System Operation and Utilization Plan

USQ Unreviewed Safety Question

WIT Waste Disposal Integration Team

WTC Whole tank composite 
HNF-2799

Revision 0

\section{APPLICATION OF "CONFIRM TANK T IS AN APPROPRIATE FEED SOURCE FOR LOW-ACTIVITY WASTE FEED BATCH X" TO 241-AN-103 / BATCH 4}

\subsection{INTRODUCTION}

This addendum applies Revision 1 of "Confirm Tank $T$ is an Appropriate Feed Source for Low-Activity Waste Feed Batch X" problem-specific data quality objectives (PSDQO) to tank 241-AN-103 / Batch 4.

This application of the DQO is divided into a Base Case Operating Scenario and an Alternative Case Operating Scenario. The Base Case homogenizes the waste in tank 241-AN-103 by mixing prior to transfer to 241-AP-102 and -104. The Alternative Case transfers the tank 241-AN-103 supernate to 241-AP-102 and -104 without mixing followed by subsequent diluent addition and mixing in 241-AN-103 before transfer to 241-AP-102 and -104 .

\subsection{EVALUATION}

\subsection{BASE CASE OPERATING SCENARIO}

Translate the operating scenario into a series of process steps.

The base case operating scenario from the Tank Waste Remediation System Operation and Utilization Plan (TWRSO\&UP) (Kirkbride et al. 1997) includes the following steps to make up Batch 4:

- Empty 241-AP-102 and -104 (the feed staging tanks) leaving a 0.1 ML (10-in.) heel behind in each tank.

- Homogenize the waste in 241-AN-103 using mixer pumps to resuspend the salt slurry.

- Transfer half of the homogenized waste in 241-AN-103 to 241-AP-102 and the remaining half to 241 -AP-104, leaving a $0.1 \mathrm{ML}$ (10-in.) heel. During the transfer, the proper amount of diluent will be added to the waste at the transfer pump inlet.

- Mix the waste in 241-AP-102 and mix the waste in 241-AP-104.

- Allow undissolved solids to settle. 
The heel remaining in 241-AP-102 and -104 can be neglected for the purposes of this PSDQO; how clean the staging tank needs to be is an operational issue, not a "Confirm Tank T..." issue. Furthermore, diluted Batch 3 waste will be within Envelope A specifications, and mixing wastes from different tanks/batches within the defined specifications should not have an adverse effect on operations.

Define the waste that applies to each element in the decision rule.

Element 1, Dilution Ratio and Diluent Composition: this applies to the whole tank composite (WTC) of 241-AN-103 over the temperature of $45^{\circ} \mathrm{C}$.

Element 2, Transfer Requirements: there are two nearly identical transfers; they will be treated as one transfer. Transfer requirements apply to a whole tank composite of the waste currently in 241-AN-103 after addition of the proper amount of diluent over the temperature range of 25 to $65^{\circ} \mathrm{C}$.

Element 3, Mixing Requirements: the mixing requirement applies to a salt slurry composite of the waste currently in $241-\mathrm{AN}-103$ over the temperature of $45^{\circ} \mathrm{C}$.

Element 4, Envelope Requirements: there is one unique Batch 4 composition; the composition and physical properties are that of a whole tank composite of the waste currently in 241-AN-103 after addition of the proper amount of diluent over the temperature of $45^{\circ} \mathrm{C}$. The dilute heel in 241-AP-102 and -104 can be neglected for the purposes of this PSDQO (all current data strongly indicate that the 241-AP-102 and -104 heel will not interfere with staging the compositionally correct feed); how clean the tank needs to be is an operational issue, not a "Confirm Tank T..." issue.

Element 5, Miscellaneous Inputs: These inputs apply to the whole tank composition of 241-AN-103 or to changes in the operating scenario that may be imposed in the future.

Evaluate existing data and determine information needs.

Table 1 contains the evaluation of the base case operating scenario for all the elements of the decision rules found in Section 6 of the PSDQO. The table lists each element taken from Section 4.0 of the PSDQO. For each element, the requirements specific to 241-AN-103 / Batch 4 are listed. Each requirement is evaluated against existing data and the remaining information needs are identified. The information needs are summarized in Table 3.

\subsection{ALTERNATIVE CASE OPERATING SCENARIO}

Translate the operating scenario into a series of process steps.

The TWRSO\&UP (Kirkbride et al. 1997) recommended that process control issues be taken into account. This alternative case operating scenario was developed based on 
consideration of process control issues and is currently being evaluated and incorporated into the project master baseline schedule and corresponding logic diagrams. The steps that directly affect the composition of Batch 4 are listed below:

- Empty 241-AP-102 and -104 (the feed staging tanks) leaving a $0.1 \mathrm{ML}$ (10-in.) heel behind in each tank.

- Decant the supernate in 241-AN-103; transfer half of the supernate to 241-AP-102 and the remainder to 241-AP-104, leaving a 10-in. heel above the salt slurry. During these transfers diluent will be added to the waste at the pump inlet.

- Add diluent to the salt slurry in 241-AN-103 and mix.

- Allow undissolved solids to settle in 241-AN-103.

- Transfer half of the liquid in 241-AN-103 to 241-AP-102 and the remaining to 241-AP-104, leaving a 10-in. heel. No additional diluent is expected to be needed for the transfer.

- Mix the waste in 241-AP-102 and mix the waste in 241-AP-104.

- Allow any undissolved solids that were inadvertently entrained to settle in 241-AP-102 and -104.

The heel remaining in 241-AP-102 and -104 can be neglected for the purposes of this PSDQO; how clean the staging tank needs to be is an operational issue, not a "Confirm Tank T..." issue. Furthermore, diluted Batch 3 waste will be within Envelope A specifications, and mixing wastes from different tanks/batches within the defined specifications should not have an adverse effect on operations.

Define the waste that applies to each element in the decision rule.

Element 1, Dilution Ratio and Diluent Composition: this applies to (a) a supernate composite from 241-AN-103 and (b) a salt slurry composite from 241-AN-103, both over the temperature range of 25 to $65^{\circ} \mathrm{C}$.

Element 2, Transfer Requirements: out of four transfers, there are two distinct transfers. The transfer requirements applies to (a) supernate composite from 241-AN-103 after addition of the proper amount of diluent and (b) a salt slurry composite from 241-AN-103 after addition of the proper amount of diluent and settling of undissolved solids over the temperature range of 25 to $65^{\circ} \mathrm{C}$.

Element 3, Dissolution Requirements: the dissolution requirements applies to the whole tank composite of the waste currently in 241-AN-103 over the temperature range of 25 to $65^{\circ} \mathrm{C}$. 
HNF-2799

Revision 0

Element 4, Envelope Requirements: there is one unique Batch 4 composition; the composition and physical properties are that of a whole tank composite of the waste currently in 241-AN-103 after addition of the proper amount of diluent over the temperature range of 25 to $65^{\circ} \mathrm{C}$. The dilute heel in 241-AP-102 and -104 can be neglected for the purposes of this PSDQO (all current data strongly indicate that 241-AP-102 and -104 heel will not interfere with staging the compositionally correct feed); how clean the tank needs to be is an operational issue, not a "Confirm Tank T..." issue.

Element 5, Miscellaneous Inputs: these inputs apply to the whole tank composition of 241-AN-103 or to changes in the operating scenario that may be imposed in the future.

Evaluate existing data and determine information needs.

Table 2 contains the evaluation of the alternative case operating scenario for all the elements of the decision rule found in Section 6 of the DQO for Confirm Tank T. The table lists each element of the decision rule taken from Section 4.0 of the DQO. For each element, the requirements specific to 241-AN-103 / Batch 4 are listed. Each requirement is evaluated against existing data and remaining information needs are identified. The information needs are developed more fully in Table 3. 
Table 1. Base Case Operating Scenario Evaluation. (6 Sheets)

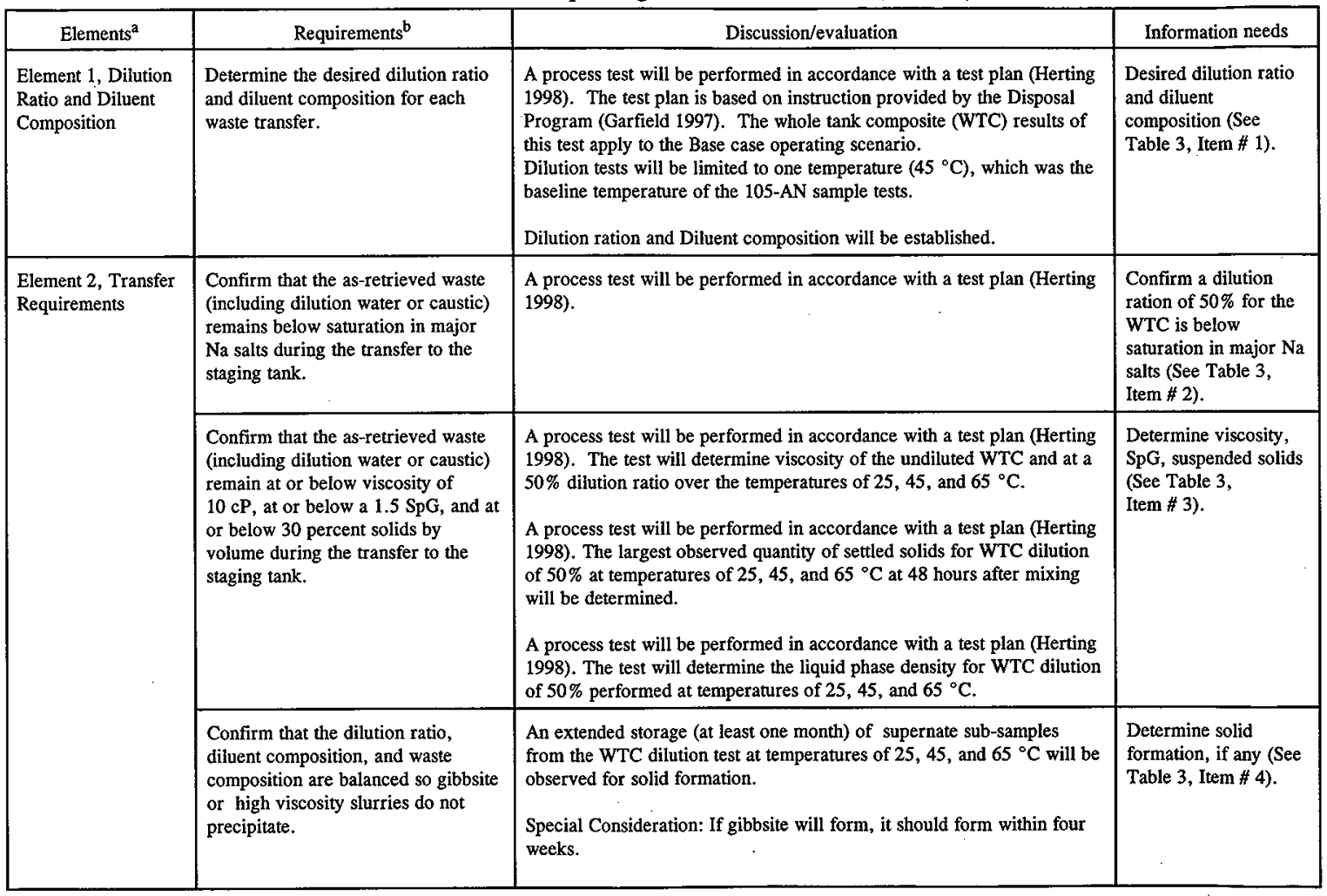


Table 1. Base Case Operating Scenario Evaluation. (6 Sheets)

\begin{tabular}{|c|c|c|c|}
\hline Elements $^{\mathrm{a}}$ & Requirements ${ }^{b}$ & Discussion/evaluation & Information needs \\
\hline \multirow[t]{3}{*}{$\begin{array}{l}\text { Element 3, Mixing } \\
\text { Requirements }\end{array}$} & $\begin{array}{l}\text { Confirm that the portion of the } \\
\text { solids thought to be soluble are } \\
\text { soluble and that they dissolve in a } \\
\text { reasonable amount of time. }\end{array}$ & $\begin{array}{l}\text { The Base case operating scenario (Kirkbride et al. 1997) assumed that } \\
\text { the majority of the solids in } 241 \text {-AN-103 would dissolve. A process } \\
\text { test will be performed in accordance with a test plan (Herting 1998). } \\
\text { Amount of undissolved solids will be determined at } 50 \% \text { dilution for } \\
\text { temperature of } 45^{\circ} \mathrm{C} \text {. During the test, amount of time needed to } \\
\text { dissolve the sample will be recorded }\end{array}$ & $\begin{array}{l}\text { Amount of } \\
\text { undissolved solids and } \\
\text { the amount of time } \\
\text { needed to dissolve the } \\
\text { solids (See Table 3, } \\
\text { Item \# 5). }\end{array}$ \\
\hline & $\begin{array}{l}\text { Confirm that the undissolved solids } \\
\text { settle and that they settle in a } \\
\text { reasonable amount of time. }\end{array}$ & $\begin{array}{l}\text { A process test will be performed to determine settling rate for the } \\
\text { undissolved solids. } \\
\text { Scale-up calculations for Herting's settling data have not been } \\
\text { performed. } \\
\text { The base case time allocated in the TWRSO\&UP (Kirkbride et al. 1997, } \\
\text { Assumption } 6.11 \text { ) for settling is taken by reference from (Certa et al. } \\
\text { 1996) and is } 30 \text { days. }\end{array}$ & $\begin{array}{l}\text { Settling rate for the } \\
\text { undissolved solids. } \\
\text { Estimated time to } \\
\text { settle undissolved } \\
\text { solids at full scale. } \\
\text { (See Table } 3 \text {, } \\
\text { Item \# 6). }\end{array}$ \\
\hline & $\begin{array}{l}\text { Confirm that the baseline retrieval } \\
\text { equipment that will be used to } \\
\text { mobilize and transfer the waste is } \\
\text { consistent with the operating } \\
\text { scenario. }\end{array}$ & $\begin{array}{l}\text { Tank } 241-\mathrm{AN}-103 \text { contains about } 48 \% \text { by weight of a salt slurry. } \\
\text { (Wilkins 1997). The base case operating scenario targets most of the } \\
\text { sodium in the salt slurry for feed. The equipment required to mobilize } \\
\text { and retrieve the slurry includes mixer pumps and a transfer pump with } \\
\text { water (and caustic) dilution capability (Boston 1997). This is consistent } \\
\text { with the equipment identified in the base case operating scenario } \\
\text { (Kirkbride et al. 1997). } \\
\text { Retrieval equipment to be added to } 241-\mathrm{AN}-103 \text { will accomplish } \\
\text { requirements. }\end{array}$ & $\begin{array}{l}\text { No further information } \\
\text { is needed. }\end{array}$ \\
\hline
\end{tabular}


Table 1. Base Case Operating Scenario Evaluation. (6 Sheets)

\begin{tabular}{|c|c|c|c|}
\hline Elements $^{\mathrm{a}}$ & Requirements ${ }^{b}$ & Discussion/evaluation & Information needs \\
\hline \multirow{3}{*}{$\begin{array}{l}\text { Element } 4 \text { - Part } 1 \text { : } \\
\text { Envelope } \\
\text { Requirements } \\
\text { These limits apply to } \\
\text { the feed actually } \\
\text { delivered to the } \\
\text { private contractors. }\end{array}$} & $\begin{array}{l}\text { Concentration limits for the } \\
\text { chemical and radionuclide content of } \\
\text { the feed (DOE-RL 1996, Section } \\
\text { C.6). } \\
\text { See Section 2.0, Tables } 1 \text { and } 2 \text { (in } \\
\text { main report) for the limits. }\end{array}$ & $\begin{array}{l}\text { Only Envelope A limits apply to Batch } 4 \text {. } \\
\text { The TWRSO\&UP (Kirkbride et al. 1997, Tables I-1 and I-3)) compared } \\
\text { the point estimates }{ }^{1} \text { of the composition of the feed from } 241 \text {-AN- } 103 \text { to } \\
\text { the Envelope limits. All analytes were below } 80 \% \text { of their maximum } \\
\text { limits. }\end{array}$ & $\begin{array}{l}\text { Chemical and } \\
\text { radionuclide analyses } \\
\text { from Herting's tests } \\
\text { (See Table 3, } \\
\text { Item \# 7). }\end{array}$ \\
\hline & $\begin{array}{l}\text { Concentration limit for the sodium } \\
\text { concentration of the feed: } \\
3 \mathrm{M} \leq \text { [Na] } \leq 14 \mathrm{M} \text { (DOE-RL } \\
1996 \text {, Section C.6). }\end{array}$ & During Herting's process test [Na] will be measured. & $\begin{array}{l}\text { [Na] measurement } \\
\text { (See Table 3, } \\
\text { Item \# 8). }\end{array}$ \\
\hline & $\begin{array}{l}\text { Insoluble solids fraction limit will } \\
\text { not exceed } 5 \text { volume \% (DOE-RL } \\
\text { 1996, Section C.6). }\end{array}$ & $\begin{array}{l}\text { The contracts do not define how the volume percent insoluble solids will } \\
\text { be measured. } \\
\text { Herting (1998) will measure the quantity of solids for WTC dilution of } \\
50 \% \text { at temperature of } 45^{\circ} \mathrm{C} \text {. }\end{array}$ & $\begin{array}{l}\text { Insoluble solids } \\
\text { measurement (See } \\
\text { Table 3, Item \# 9). }\end{array}$ \\
\hline
\end{tabular}

${ }^{1}$ These point estimates were based on the best basis inventory for 241-AN-103. A thermodynamic model (ESP) was used to estimate the liquid phase composition of the diluted waste. 
Table 1. Base Case Operating Scenario Evaluation. (6 Sheets)

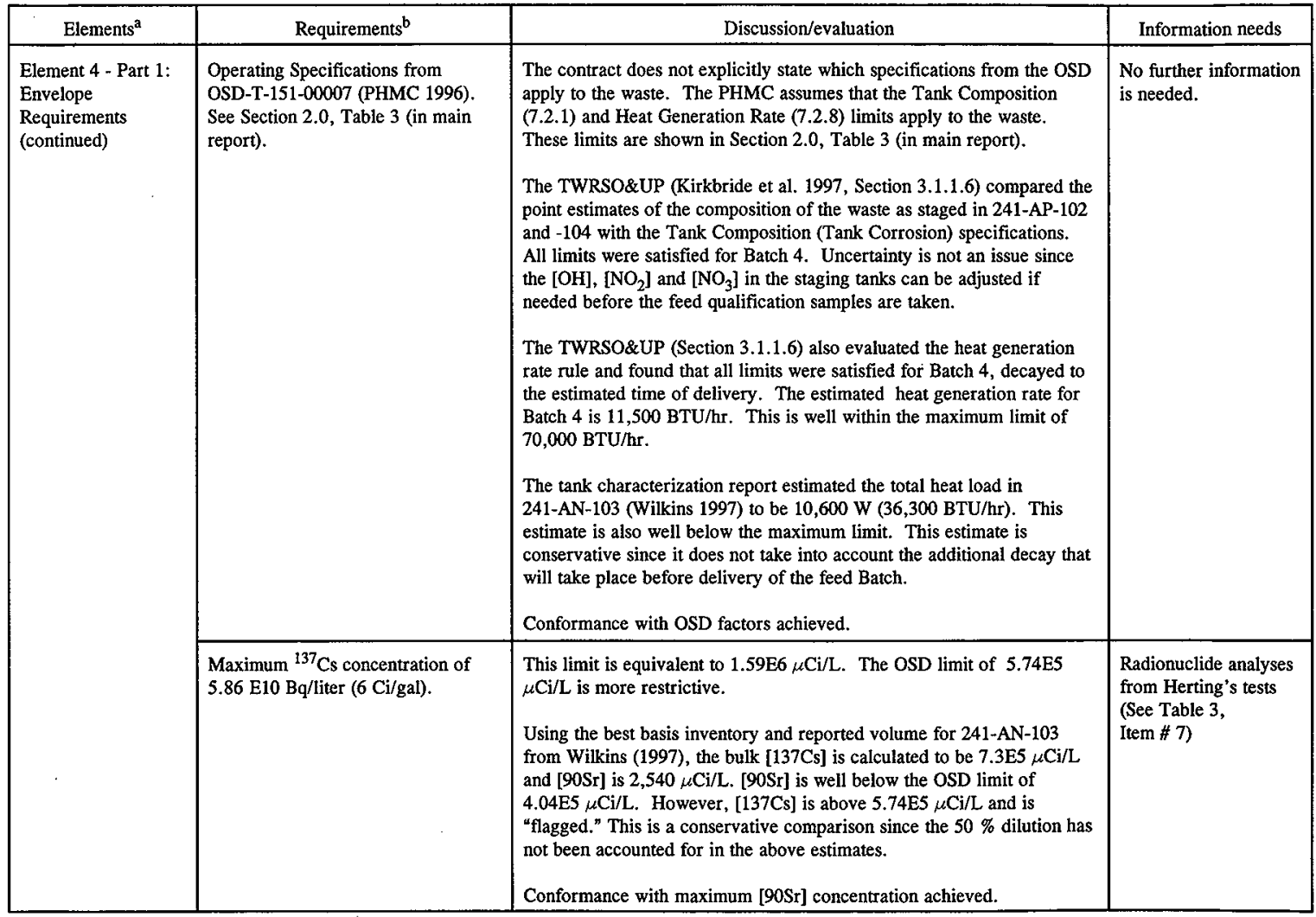


Table 1. Base Case Operating Scenario Evaluation. (6 Sheets)

\begin{tabular}{|c|c|c|c|}
\hline Elements $^{\mathrm{a}}$ & Requirements $^{\mathrm{b}}$ & Discussion/evaluation & Information needs \\
\hline $\begin{array}{l}\text { Element } 4 \text { - Part } 1 \text { : } \\
\text { Envelope } \\
\text { Requirements } \\
\text { (continued) }\end{array}$ & $\begin{array}{l}\text { The PHMC assumed minimum } \\
\text { limits to distinguish between } \\
\text { Envelope } A \text { and } C \text { and between } \\
\text { Envelopes } A \text { and } B\end{array}$ & $\begin{array}{l}\text { These discriminators do not apply to Batch } 4 \text { (Envelope A). } \\
\text { No concern about distinguishing between envelopes. }\end{array}$ & $\begin{array}{l}\text { No further information } \\
\text { is needed. }\end{array}$ \\
\hline \multirow[t]{3}{*}{$\begin{array}{l}\text { Element } 4 \text { - Part 2: } \\
\text { Quantity } \\
\text { Requirements }\end{array}$} & $\begin{array}{l}\text { Batch size (mass of sodium) } \\
\text { constraints (from the contracts) } 2 \\
100 \mathrm{MT} \mathrm{Na} \text {. }\end{array}$ & $\begin{array}{l}\text { During Herting's process test, amount of Na recoverable will be } \\
\text { measured at } 50 \% \text { dilution ratio }\end{array}$ & $\begin{array}{l}\text { Determine Na quantity } \\
\text { (See Table } 3 \text {, } \\
\text { Item \# 10). }\end{array}$ \\
\hline & $\begin{array}{l}\text { PHMC targeted batch size range } \\
\text { (from the ICD (PHMC 1997, } \\
\text { Table 3D): } 250 \text { - } 600 \mathrm{MT} \text { Na. }\end{array}$ & Same as above. & $\begin{array}{l}\text { Determine Na quantity } \\
\text { (See Table } 3 \text {, } \\
\text { Item \# 10). }\end{array}$ \\
\hline & $\begin{array}{l}\text { PHMC desired batch size (from } \\
\text { Operating Scenario): } 585 \mathrm{MT} \mathrm{Na} \\
\text { (Kirkbride et al. 1997, Table } 3.1-5 \text { ) }\end{array}$ & Same as above. & $\begin{array}{l}\text { Determine Na quantity } \\
\text { (See Table } 3 \text {, } \\
\text { Item \# 10). }\end{array}$ \\
\hline \multirow[t]{4}{*}{$\begin{array}{l}\text { Element } 5 \text { - } \\
\text { Miscellaneous Inputs }\end{array}$} & Physical form of Tank $T$ contents & $\begin{array}{l}\text { From Wilkins (1997): } 241-\mathrm{AN}-103 \text { has a noncontinuous floating crust } \\
\text { layer that may be up to } 43 \mathrm{~cm} \text { ( } 17 \mathrm{in}) \text { thick. The layer is easily } \\
\text { penetrated and is composed of easily dissolvable salts. There is } \\
\text { approximately } 4.6 \mathrm{~m} \text { (15 ft) of supernate which is compositionally } \\
\text { homogenous. There are approximately } 3.8 \mathrm{~m} \text { ( } 12.4 \mathrm{ft}) \text { of settled solids. } \\
\text { There could be hard pan at the bottom. }\end{array}$ & $\begin{array}{l}\text { No further information } \\
\text { is needed }\end{array}$ \\
\hline & $\begin{array}{l}\text { Heel from prior batch remaining in } \\
\text { staging tanks }\end{array}$ & $\begin{array}{l}\text { Heels remaining from clean out of } 241-A P-102 \text { and }-104 \text { are addressed } \\
\text { in Section } 2.1 \text { above. }\end{array}$ & $\begin{array}{l}\text { No further information } \\
\text { is needed }\end{array}$ \\
\hline & Shimming Batch 4 & No shimming is anticipated. & $\begin{array}{l}\text { No further information } \\
\text { is needed }\end{array}$ \\
\hline & RL direction & $\begin{array}{l}\text { No changes to applicable M\&I ICD requirements have been made to } \\
\text { date. }\end{array}$ & $\begin{array}{l}\text { No further information } \\
\text { is needed }\end{array}$ \\
\hline
\end{tabular}

a. Elements are taken from the Decision Rule statement in Section 4.0 of PSDQO-01.

b. Requirements are taken from Sections $4.1,4.2,4.3,4.4$, and 4.5 of PSDQO-01. 
Table 2. Alternative Case Operating Scenario Evaluation. (4 Sheets)

\begin{tabular}{|c|c|c|c|}
\hline Elements ${ }^{a}$ & Requirements ${ }^{b}$ & Discussion/evaluation & Information needs \\
\hline \multirow[t]{2}{*}{$\begin{array}{l}\text { Element } 1 \text {, Dilution } \\
\text { Ratio and Diluent } \\
\text { Composition }\end{array}$} & \multirow[t]{2}{*}{$\begin{array}{l}\text { Determine the desired dilution ratio } \\
\text { and diluent composition for each } \\
\text { waste transfer. }\end{array}$} & $\begin{array}{l}\text { (a) As applied to supernate composite: Liquid samples will be diluted } \\
10 \% \text { and } 20 \% \text { by volume with water. } \\
\text { This information will be obtained per Herting's process test (1998). }\end{array}$ & $\begin{array}{l}\text { Desired dilution ratio } \\
\text { and diluent } \\
\text { composition for a } \\
\text { representative sample } \\
\text { of supernate (See } \\
\text { Table } 3 \text {, Item \# } 11 \text { ) }\end{array}$ \\
\hline & & $\begin{array}{l}\text { (b) As applied to salt slurry composite: A process test will be } \\
\text { performed (Herting 1998). The test plan was based on instruction } \\
\text { provided by the Disposal Program (Garfield 1997). The settled solid } \\
\text { samples will be diluted } 0,40,80 \text {, and } 120 \% \text { by volume with water. }\end{array}$ & $\begin{array}{l}\text { Desired dilution ratio } \\
\text { and diluent } \\
\text { composition for a } \\
\text { representative sample } \\
\text { of supernate (See } \\
\text { Table 3, Item \# 11) }\end{array}$ \\
\hline \multirow[t]{4}{*}{$\begin{array}{l}\text { Element 2, Transfer } \\
\text { Requirements are } \\
\text { Satisfied }\end{array}$} & \multirow{2}{*}{$\begin{array}{l}\text { Confirm that the as-retrieved waste } \\
\text { (including dilution water or caustic) } \\
\text { remains below sanuration in major } \\
\text { Na salts during the transfer to the } \\
\text { staging tank. }\end{array}$} & $\begin{array}{l}\text { (a) As applied to supernate composite with proper amount of diluent } \\
\text { added: A process test will be performed (Herting 1998). }\end{array}$ & $\begin{array}{l}\text { See requirement (See } \\
\text { Table 3, Item \# 12). }\end{array}$ \\
\hline & & $\begin{array}{l}\text { (b) As applied to salt slurry composite with proper amount of diluent } \\
\text { added: A process test will be performed (Herting 1998). }\end{array}$ & $\begin{array}{l}\text { See requirement (See } \\
\text { Table 3, Item \# 12). }\end{array}$ \\
\hline & \multirow[t]{2}{*}{$\begin{array}{l}\text { Confirm that the as-retrieved waste } \\
\text { (including dilution water or caustic) } \\
\text { remain at or below viscosity of } \\
10 \mathrm{cP} \text {, at or below a } 1.5 \mathrm{SpG} \text {, and at } \\
\text { or below } 30 \text { percent solids by } \\
\text { volume during the transfer to the } \\
\text { staging tank. }\end{array}$} & $\begin{array}{l}\text { (a) As applied to supernate composite with proper amount of diluent } \\
\text { added: A process test will be performed (Herting 1998). }\end{array}$ & $\begin{array}{l}\text { See requirement (See } \\
\text { Table 3, Item \# 13). }\end{array}$ \\
\hline & & $\begin{array}{l}\text { (b) As appilied to salt slurry composite with proper amount of diluent } \\
\text { added: A process test will be performed (Herting 1998). }\end{array}$ & $\begin{array}{l}\text { See requirement (See } \\
\text { Table 3, Item \# 13). }\end{array}$ \\
\hline
\end{tabular}


Table 2. Alternative Case Operating Scenario Evaluation. (4 Sheets)

\begin{tabular}{|c|c|c|c|}
\hline Elements $^{a}$ & Requirements ${ }^{b}$ & Discussion/evaluation & Information needs \\
\hline \multirow[t]{3}{*}{$\begin{array}{l}\text { Element 3, } \\
\text { Dissolution } \\
\text { Requirements }\end{array}$} & $\begin{array}{l}\text { Confirm that the portion of the } \\
\text { solids thought to be soluble are } \\
\text { soluble and that they dissolve in a } \\
\text { reasonable amount of time. }\end{array}$ & $\begin{array}{l}\text { The Base case operating scenario (Kirkbride et al. 1997) assumed that } \\
\text { the majority of the solids in } 241-\mathrm{AN}-103 \text { would dissolve. } \\
\text { A process test will be performed (Herting 1998). }\end{array}$ & $\begin{array}{l}\text { Amount of soluble } \\
\text { solids and amount of } \\
\text { time required to } \\
\text { dissolve soluble solids } \\
\text { (See Table 3, } \\
\text { Item \# 15). }\end{array}$ \\
\hline & $\begin{array}{l}\text { Confirm that the undissolved solids } \\
\text { settle and that they settle in a } \\
\text { reasonable amount of time. }\end{array}$ & $\begin{array}{l}\text { A process test will be performed to determine settling rate for the } \\
\text { undissolved solids. } \\
\text { Scale-up calculations for Herting's settling data have not been } \\
\text { performed. }\end{array}$ & $\begin{array}{l}\text { Settling rate for the } \\
\text { undissolved solids. } \\
\text { Estimated time to } \\
\text { settle undissolved } \\
\text { solids at full scale } \\
\text { (See Table } 3 \text {, } \\
\text { Item } \# 16 \text { ). }\end{array}$ \\
\hline & $\begin{array}{l}\text { Confirm that the baseline retrieval } \\
\text { equipment that will be used to } \\
\text { mobilize and transfer the waste is } \\
\text { consistent with the operating } \\
\text { scenario. }\end{array}$ & $\begin{array}{l}\text { The alternative case uses the same retrieval equipment as the base case. } \\
\text { See base case evaluation for details. } \\
\text { Retrieval equipment to be added to AN-104 will accomplish } \\
\text { requirements. }\end{array}$ & $\begin{array}{l}\text { No further } \\
\text { information is } \\
\text { needed. }\end{array}$ \\
\hline $\begin{array}{l}\text { Element } 4 \text { - Part 1: } \\
\text { Envelope } \\
\text { Requirements } \\
\text { These limits apply to } \\
\text { the feed actually } \\
\text { delivered to the } \\
\text { private contractors. }\end{array}$ & $\begin{array}{l}\text { Concentration limits for the } \\
\text { chemical and radionuclide content of } \\
\text { the feed (DOE-RL 1996, } \\
\text { Section C.6). } \\
\text { See Section 2.0, Tables } 1 \text { and } 2 \text { (in } \\
\text { main report) for the limits. }\end{array}$ & $\begin{array}{l}\text { Only Envelope A limits apply to Batch } 4 \text {. } \\
\text { In the alternative case, the composition of the waste staged in } \\
241-\mathrm{AP}-102 \text { and }-104 \text { is almost identical to that of the base case. There } \\
\text { will be differences in absolute concentration due to differences in the } \\
\text { total amount of dilution, but this will not affect the [analyte]:[Na] } \\
\text { values. There will also be differences due to slightly different extent of } \\
\text { solids dissolution. }\end{array}$ & $\begin{array}{l}\text { Chemical and } \\
\text { radionuclide analyses } \\
\text { from Herting's tests } \\
\text { (See Table 3, } \\
\text { Item \# 17). }\end{array}$ \\
\hline
\end{tabular}


Table 2. Alternative Case Operating Scenario Evaluation. (4 Sheets)

\begin{tabular}{|c|c|c|c|}
\hline Elements $^{\mathrm{a}}$ & Requirements $^{b}$ & Discussion/evaluation & Information needs \\
\hline \multirow[t]{5}{*}{$\begin{array}{l}\text { Element } 4 \text { - Part } 1 \text { : } \\
\text { Envelope } \\
\text { Requirements } \\
\text { (continued) }\end{array}$} & $\begin{array}{l}\text { Concentration limit for the sodium } \\
\text { concentration of the feed: } \\
3 \mathrm{M} \leq[\mathrm{Na}] \leq 14 \mathrm{M} \text { (DOE-RL } \\
1996 \text {, Section C.6). }\end{array}$ & During Herting's process test [Na] will be measured. & $\begin{array}{l}\text { Chemical and } \\
\text { radionuclide analyses } \\
\text { from Herting's tests } \\
\text { (See Table 3, } \\
\text { Item \# 17). }\end{array}$ \\
\hline & $\begin{array}{l}\text { Insoluble solids fraction limit will } \\
\text { not exceed } 5 \text { volume \% (DOE-RL } \\
\text { 1996, Section C.6). }\end{array}$ & $\begin{array}{l}\text { In the alternative case, the only solids that should end up in the feed } \\
\text { batch are those solids that are inadvertently entrained during the decant } \\
\text { transfers. This is an operational issue, not a "Confirm Tank } T . . . \text { issue. } \\
\text { Compliance with insoluble fraction will be resolved by case during } \\
\text { operations. }\end{array}$ & $\begin{array}{l}\text { No further } \\
\text { information is } \\
\text { needed. }\end{array}$ \\
\hline & $\begin{array}{l}\text { Operating Specifications from } \\
\text { OSD-T-151-00007 (DOE-RL } 1996 \text {, } \\
\text { Section C.6 invokes the OSD by } \\
\text { reference). } \\
\text { See Section 2.0, Table } 3 \text { (in main } \\
\text { report). }\end{array}$ & $\begin{array}{l}\text { Mass balances have not been performed on the alternative case } \\
\text { operating scenario to estimate the composition of the staged feed batch } \\
\text { (these can be done explicitly after the supernate dilution ratio has been } \\
\text { determined. Bounding calculations can be performed, however it is } \\
\text { simpler to wait for the dilution ratio. }\end{array}$ & $\begin{array}{l}\text { Estimated } \\
\text { composition of the } \\
\text { staged feed (See } \\
\text { Table 3, Item \# 18). }\end{array}$ \\
\hline & $\begin{array}{l}\text { Maximum }{ }^{137} \mathrm{Cs} \text { concentration of } \\
5.86 \mathrm{E} 10 \mathrm{~Bq} / \text { liter }(6 \mathrm{Ci} / \mathrm{gal}) \text {. }\end{array}$ & $\begin{array}{l}\text { This limit is equivalent to } 1.59 \mathrm{E} 6 \mu \mathrm{Ci} / \mathrm{L} \text {. The OSD limit of } 5.74 \mathrm{E} 5 \\
\mu \mathrm{Ci} / \mathrm{L} \text { is more restrictive. } \\
\text { Using the best basis inventory and reported volume for } 241-\mathrm{AN}-103 \\
\text { from Wilkins }(1997) \text {, the bulk [ } 137 \mathrm{Cs} \text { ] is calculated to be } 7.3 \mathrm{ES} \mu \mathrm{Ci} / \mathrm{L} \\
\text { and [ } 90 \mathrm{Sr}] \text { is } 2,540 \mu \mathrm{Ci} / \mathrm{L} \text {. [90Sr] is well below the } \mathrm{OSD} \text { limit of } \\
4.04 \mathrm{E} 5 \mu \mathrm{Ci} / \mathrm{L} \text {. However, [137Cs] is above } 5.74 \mathrm{E} 5 \mu \mathrm{Ci} / \mathrm{L} \text { and is } \\
\text { "flagged." This is a conservative comparison since the } 50 \% \text { dilution has } \\
\text { not been accounted for in the above estimates. } \\
\text { Conformance with maximum [ } 90 \mathrm{Sr} \text { ] concentration achieved. }\end{array}$ & $\begin{array}{l}\text { Radionuclide analyses } \\
\text { from Herting's tests } \\
\text { (See Table } 3 \text {, } \\
\text { Item \# 17) }\end{array}$ \\
\hline & $\begin{array}{l}\text { The PHMC assumed minimum } \\
\text { limits to distinguish between } \\
\text { Envelope } \mathrm{A} \text { and } \mathrm{C} \text { and between } \\
\text { Envelopes } \mathrm{A} \text { and } \mathrm{B}\end{array}$ & $\begin{array}{l}\text { These discriminators do not apply to Batch } 4 \text { (Envelope A). } \\
\text { No concern about distinguishing between envelopes. }\end{array}$ & $\begin{array}{l}\text { No further } \\
\text { information is } \\
\text { needed. }\end{array}$ \\
\hline
\end{tabular}


Table 2. Alternative Case Operating Scenario Evaluation. (4 Sheets)

\begin{tabular}{|c|c|c|c|}
\hline Elements $^{\mathrm{a}}$ & Requirements ${ }^{b}$ & Discussion/evaluation & Information needs \\
\hline \multirow{3}{*}{$\begin{array}{l}\text { Element } 4 \text { - Part 2: } \\
\text { Quantity } \\
\text { Requirements are } \\
\text { Satisfied }\end{array}$} & $\begin{array}{l}\text { Batch size (mass of sodium) } \\
\text { constraints (from the contracts) } 2 \\
100 \text { MT Na. }\end{array}$ & $\begin{array}{l}\text { During Herting's process test, amount of } \mathrm{Na} \text { recoverable will be } \\
\text { measured. }\end{array}$ & $\begin{array}{l}\text { Determine Na } \\
\text { quantity (See Table 3, } \\
\text { Item \# 17). }\end{array}$ \\
\hline & $\begin{array}{l}\text { PHMC targeted batch size range } \\
\text { (from the ICD (PHMC 1997, } \\
\text { Table 3D): } 250 \text { - 600 MT Na. }\end{array}$ & Same as above. & $\begin{array}{l}\text { No further } \\
\text { information is } \\
\text { needed. }\end{array}$ \\
\hline & $\begin{array}{l}\text { PHMC desired batch size (from } \\
\text { Operating Scenario): } 585 \mathrm{MT} \mathrm{Na} \\
\text { (Kirkbride et al. 1997, Table 3.1-5) }\end{array}$ & $\begin{array}{l}\text { Same as above. } \\
\text { Na quantity requirements will be resolved administratively or by } \\
\text { shimming. }\end{array}$ & $\begin{array}{l}\text { No further } \\
\text { information is } \\
\text { needed. }\end{array}$ \\
\hline \multirow[t]{5}{*}{$\begin{array}{l}\text { Element } 5 \text { - } \\
\text { Miscellaneous Inputs }\end{array}$} & Physical form of Tank $T$ contents & $\begin{array}{l}\text { From Wilkins (1997): } 241-\mathrm{AN}-103 \text { has a noncontinuous floating crust } \\
\text { layer that may be up to } 43 \mathrm{~cm}(17 \text { in) thick. The layer is easily } \\
\text { penetrated and is composed of easily dissolvable salts. There is } \\
\text { approximately } 4.6 \mathrm{~m} \text { (15 ft) of supernate which is compositionaliy } \\
\text { homogenous. There are approximately } 3.8 \mathrm{~m} \text { (12.4 ft) of settled solids. } \\
\text { There could be hard pan at the bottom. }\end{array}$ & $\begin{array}{l}\text { No further } \\
\text { information is needed }\end{array}$ \\
\hline & $\begin{array}{l}\text { Heel from prior batch remaining in } \\
\text { staging tanks }\end{array}$ & $\begin{array}{l}\text { Heels remaining from clean out of } 241-\mathrm{AP}-102 \text { and }-104 \text { are addressed } \\
\text { in Section } 2.1 \text { above. }\end{array}$ & $\begin{array}{l}\text { No further } \\
\text { information is needed }\end{array}$ \\
\hline & Shimming Batch 4 & No shimming is anticipated. & $\begin{array}{l}\text { No further } \\
\text { information is needed }\end{array}$ \\
\hline & RL direction & $\begin{array}{l}\text { No changes to applicable M\&I ICD requirements have been made to } \\
\text { date. }\end{array}$ & $\begin{array}{l}\text { No further } \\
\text { information is needed }\end{array}$ \\
\hline & Heating and Cooling Curves & $\begin{array}{l}\text { Perform a process test (Herting 1998) to generate heating and cooling } \\
\text { curves with whole tank composite. }\end{array}$ & $\begin{array}{l}\text { Determine heating } \\
\text { and cooling curves } \\
\text { (See Table } 3 \text {, } \\
\text { Item } \# 19 \text { ). }\end{array}$ \\
\hline
\end{tabular}

${ }^{\mathrm{a}}$ Elements are taken from the Decision Rule statement in Section 4.0 of PSDQO-01.

${ }^{b}$ Requirements are taken from Sections $4.1,4.2,4.3,4.4$, and 4.5 of PSDQO-01. 
Table 3 was developed jointly by TWRS Characterization and Tank Waste Retrieval. It is intended to show what information is still needed, what can be obtained by calculations with existing data, what requires new (or existing) samples, analysis and/or process testing. Where samples are required, the amount and "representativeness" of the sample will be stated. Where analysis is needed, the specific analytes and QA requirements will be stated. If process testing is needed, the amount of sample and goals of the process test will be stated. Appropriate level of end description of QA requirements will be covered in the specific work plan for these limited process tests.

Table 3. Information Needs. (2 Sheets)

\begin{tabular}{|l|l|l|l|}
\hline Item & \multicolumn{1}{|c|}{ Information need } & \multicolumn{1}{|c|}{ Planned resolution } & \multicolumn{1}{|c|}{$\begin{array}{c}\text { Sample } \\
\text { required }\end{array}$} \\
\hline 1 & $\begin{array}{l}\text { Desired dilution ratio } \\
\text { and diluent composition }\end{array}$ & A process test will be performed & $\begin{array}{l}500 \text { mL of } \\
\text { 241-AN-103 }\end{array}$ \\
\hline 2 & $\begin{array}{l}\text { Confirm a dilution ratio } \\
\text { of 50\% for the WTC is } \\
\text { below saturation in } \\
\text { major Na salts }\end{array}$ & $\begin{array}{l}\text { A process test will be performed. Sample } \\
\text { from Item 1 should be used. }\end{array}$ & None. \\
\hline 3 & $\begin{array}{l}\text { Determine viscosity, } \\
\text { SpG, suspended solids }\end{array}$ & $\begin{array}{l}\text { A process test will be performed. Samples } \\
\text { from Item \#1 should be used. }\end{array}$ & None. \\
\hline 4 & $\begin{array}{l}\text { Determine solid } \\
\text { formation, if any }\end{array}$ & A process test will be performed & None. \\
\hline 5 & $\begin{array}{l}\text { Amount of undissolved } \\
\text { solids and the amount } \\
\text { of time needed to } \\
\text { dissolve the solids }\end{array}$ & A process test will be performed & None \\
\hline 6 & $\begin{array}{l}\text { Estimate time to settle } \\
\text { undissolved solids at } \\
\text { full scale }\end{array}$ & $\begin{array}{l}\text { Engineering calculations: no additional } \\
\text { tests required }\end{array}$ & None \\
\hline 7 & $\begin{array}{l}\text { Chemical and } \\
\text { radionuclide analyses } \\
\text { from Herting's test }\end{array}$ & Samples from the process test will be used. & None \\
\hline 8 & [Na] measurement & Data from Item \#1 should be used. & None \\
\hline 9 & $\begin{array}{l}\text { Insoluble solids } \\
\text { measurement }\end{array}$ & $\begin{array}{l}\text { A process test will be performed. Samples } \\
\text { from Item \#1 should be used. }\end{array}$ & None \\
\hline 10 & $\begin{array}{l}\text { Determination of Na } \\
\text { quantity }\end{array}$ & Data from Item \#1 should be used. & None \\
\hline & & & \\
\hline
\end{tabular}


Table 3. Information Needs. (2 Sheets)

\begin{tabular}{|c|c|c|c|}
\hline Item & Information need & Planned resolution & $\begin{array}{c}\text { Sample } \\
\text { required }\end{array}$ \\
\hline 11 & $\begin{array}{l}\text { Desired dilution ratio } \\
\text { and diluent composition } \\
\text { for a representative } \\
\text { sample of supernate. }\end{array}$ & Process testing will be performed. & $\begin{array}{l}500 \mathrm{~mL} \text { of } \\
241-\mathrm{AN}-103\end{array}$ \\
\hline 12 & $\begin{array}{l}\text { Confirm as-retrieved } \\
\text { waste remains below } \\
\text { satn in major Na salts } \\
\text { during transfer. }\end{array}$ & $\begin{array}{l}\text { Performing lab test: measure \%solids vs. } \\
\text { temp for supernate at } 25,45 \text { and } 65^{\circ} \mathrm{C} \\
\text { under } 3 \text { conditions: undiluted, } 10 \% \\
\text { diluted and } 20 \% \text { diluted. Samples from } \\
\text { Item } \# 11 \text { should be used. }\end{array}$ & None \\
\hline 13 & $\begin{array}{l}\text { Confirm as-retrieved } \\
\text { waste remains }<10 \mathrm{cP} \text {, } \\
<1.5 \mathrm{SpG} \text {, and }<30 \% \\
\text { solids during transfer. }\end{array}$ & $\begin{array}{l}\text { SpG, viscosity and \%Solids are being } \\
\text { measured. Samples from Item \#11 should } \\
\text { be used. }\end{array}$ & None \\
\hline 14 & $\begin{array}{l}\text { Precipitation at } 0,40, \\
80, \text { and } 120 \% \\
\text { dilutions }\end{array}$ & $\begin{array}{l}\text { Process testing will be performed at these } \\
\text { dilutions. }\end{array}$ & None \\
\hline 15 & $\begin{array}{l}\text { Amount of soluble } \\
\text { solids and amount time } \\
\text { needed to dissolve } \\
\text { soluble solids. }\end{array}$ & A process test will be performed. & None \\
\hline 16 & $\begin{array}{l}\text { Estimate time to settle } \\
\text { undissolved solids at } \\
\text { full scale }\end{array}$ & $\begin{array}{l}\text { Engineering calculations: no additional } \\
\text { tests required }\end{array}$ & None \\
\hline 17 & $\begin{array}{l}\text { Chemical and } \\
\text { radionuclide analyses } \\
\text { from Herting's test }\end{array}$ & Samples from the process test will be used. & None \\
\hline 18 & $\begin{array}{l}\text { Estimate composition } \\
\text { of staged feed. }\end{array}$ & $\begin{array}{l}\text { Can be calculated from existing data after } \\
\text { item } \# 11 \text { is resolved. }\end{array}$ & None \\
\hline 19 & $\begin{array}{l}\text { Establish heating and } \\
\text { cooling curve. }\end{array}$ & $\begin{array}{l}\text { Process test (Herting 1998) to generate } \\
\text { heating and cooling curves with whole tank } \\
\text { composite. }\end{array}$ & $500 \mathrm{~mL}$ \\
\hline
\end{tabular}

There are 19 items that have been flagged in Tables 1 and 2 requiring further information. All items are being addressed by a specific process test with specific material from 241-AN-103. There are no other information needs requiring either an analysis of an existing 241-AN-103 sample or the collection of additional sample followed by analysis in order to confirm that tank 241-AN-103 is appropriate for Batch 4. 
HNF-2799

Revision 0

\subsection{REFERENCES}

Certa, P. J., W. H. Grams, C. M. McConville, L. W. Shelton and E. J. Slaathaug, 1996, Low-Level Waste Feed Staging Plan, WHC-SD-WM-RPT-224, Rev. 0, Westinghouse Hanford Company, Richland, Washington.

DOE-RL, 1996, TWRS Privatization, Contract Numbers DE-RP06-96RL13308 and 13309, U.S. Department of Energy, Richland, Washington.

Garfield, J. S., 1997, Tank 241-AN-105 Dilution/Dissolution Test Requirements, internal memo to D. L. Herting, 8C451-97-004 (March 27), Numatec Hanford Corporation, Richland, Washington.

Herting, D. L, 1998, Test Plan for Tank 241-AN-103 Dilution Studies, HNF-2239, Rev. 0 (Draft), Numatec Hanford Corporation, Richland, Washington.

Kirkbride, R. A., G. K. Allen, P. J. Certa, A. F. Manuel, R. M. Orme, L. W. Shelton, E. J. Slaathaug, R. S. Wittman, G. T. MacLean and D. L. Penwell, 1997, Tank Waste Remediation System Operation and Utilization Plan, HNF-SD-WM-SP-012, Rev. OA, Vol. I and II, Numatec Hanford Corporation, Richland, Washington.

PHMC, 1996, Unclassified Operating Specification for the 241-AN, $A P, A W, A Y, A Z$, and $S Y$ Tank Farms, OSD-T-151-00007, Rev. H-18, Fluor Daniel Hanford, Richland, Washington.

PHMC, 1997, Interface Control Document Between DOE and the PHMC, Low-Activity Waste Feed, HNF-SP-1223 (ICD-19), Project Hanford Management Contractor, Richland, Washington.

Wilkins, N. E., J. G. Field, L. W. Shelton, and T. L. Welsh, 1998, Tank Characterization Report for Double-Shell Tank 241-AN-103, HNF-SD-WM-ER-702, Rev. OC, Lockheed Martin Hanford Corporation, Richland, Washington. 


\section{ADDENDUM 5}

\section{APPLICATION OF}

\section{"CONFIRM TANK T IS AN APPROPRIATE FEED SOURCE FOR LOW-ACTIVITY WASTE FEED BATCH $X "$}

TO

241-AZ-101 AND 241-AZ-102 / BATCH 5 
HNF-2799

Revision 0

This page intentionally left blank.

Addendum 5-2 
CONTENTS

1.0 INTRODUCTION $\ldots \ldots \ldots \ldots \ldots \ldots \ldots \ldots \ldots \ldots \ldots \ldots \ldots \ldots$ Addendum $5-5$

2.0 EVALUATION $\ldots \ldots \ldots \ldots \ldots \ldots \ldots \ldots \ldots$ Addendum 5 -7

2.1 BASE CASE OPERATING SCENARIO . . . . . . . . . . Addendum 5-7

2.2 ALTERNATIVE CASE OPERATING SCENARIO . . . . . . . Addendum 5-8

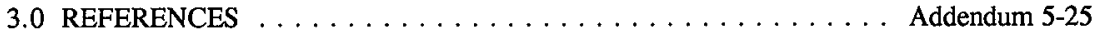

\section{LIST OF TABLES}

1. Base Case Operating Scenario Evaluation $\ldots \ldots \ldots \ldots \ldots$ Addendum 5-11

2. Alternative Case Operating Scenario Evaluation. . . . . . . . . Addendum 5-16

3. Information Needs. $\ldots \ldots \ldots \ldots \ldots \ldots \ldots \ldots \ldots \ldots$ Addendum $5-21$ 
HNF-2799

Revision 0

\section{LIST OF TERMS}

DOE U.S. Department of Energy

ICD Interface Control Document

LAW Low-Activity Waste

M $\quad$ Molar (gmoles/liter)

PHMC Project Hanford Management Contract(or)

PMBS Project Master Baseline Schedule

PSDQO Problem-Specific Data Quality Objectives

RL U.S. Department of Energy-Richland Operations

TANK T Refers to the contents from one tank, multiple tanks, or portions of one or more tanks that will be used to prepare a feed batch

TSC Tank Supernate Composite

TOC Total Organic Carbon

TWRS Tank Waste Remediation System

TWRSO\&UP Tank Waste Remediation System Operation and Utilization Plan

USQ Unreviewed Safety Question

WIT Waste Disposal Integration Team

WTC Whole tank composite 
HNF-2799

Revision 0

\begin{abstract}
APPLICATION OF "CONFIRM TANK T IS AN APPROPRIATE FEED SOURCE FOR LOW-ACTIVITY WASTE FEED BATCH X" TO 241-AZ-101 \& 241-AZ-102 / BATCH 5
\end{abstract}

\title{
1.0 INTRODUCTION
}

This addendum applies Revision 1 of "Confirm Tank $\mathbf{T}$ is an Appropriate Feed Source for Low-Activity Waste Feed Batch X" problem-specific data quality objectives (PSDQO) to tank 241-AZ-101/241-AZ-102 / Batch 5.

This application of the DQO is divided into a Base Case Operating Scenario and an Alternative Case Operating Scenario. The Base Case evaporates the supernate in tanks 241-AZ-101/241-AZ-102 by in-tank evaporation prior to transferring to tank 241-AY-101. Subsequently, the waste in the tank 241-AY-101 will be transferred to tanks 241-AP-102 and -104. The Alternative Case transfers the supernate in tanks 241-AZ-101/241-AZ-102 to tank 241-AY-101 without in-tank evaporation. Subsequently, the waste in the tank 241-AY-101 will be transferred to tanks 241-AP-102 and -104. 
HNF-2799

Revision 0

This page intentionally left blank. 
HNF-2799

Revision 0

\subsection{EVALUATION}

\subsection{BASE CASE OPERATING SCENARIO}

Translate the operating scenario into a series of process steps.

The base case operating scenario from the Tank Waste Remediation System Operation and Utilization Plan (TWRSO\&UP) (Kirkbride et al. 1997) includes the following steps to make up Batch 5:

- Empty, flush, and empty 241-AP-102 and -104 (the feed staging tanks) leaving a dilute, $0.1 \mathrm{ML}(10$-in.) heel behind in each tank.

- Mixer pump test in tank 241-AZ-101.

- In-tank evaporation of waste in 241-AZ-101/241-AZ-102 to 5M Na.

- Empty supernate from 241-AY-101 leaving supernate heel and sludge behind in each tank.

- Transfer supernate from 241-AZ-101 to 241-AY-101. During the transfer, the proper amount of diluent will be added to the waste at the transfer pump inlet.

- Transfer supernate from 241-AZ-102 to 241-AY-101 until 241-AY-101 is full . During the transfer, the proper amount of diluent will be added to the waste at the transfer pump inlet.

- Transfer supernate from 241-AY-101 to 241-AP-102 and -104.

The dilute heel in 241-AP-102 and -104 can be neglected for the purposes of this PSDQO; how clean the staging tank needs to be is an operational issue, not a "Confirm Tank T..." issue.

Define the waste that applies to each element in the decision rule.

Element 1, Dilution Ratio and Diluent Composition: this applies to the tank supernate composite (TSC) after evaporation of 241-AZ-101 and 241-AZ-102 over the temperature range of 25 to $65^{\circ} \mathrm{C}$. 
HNF-2799

Revision 0

Element 2, Transfer Requirements: There are three transfers; (1) transfer requirements apply to a TSC of the waste (after evaporation) in 241-AZ-101 to 241-AY-101 after addition of the proper amount of diluent over the temperature range of 25 to $65^{\circ} \mathrm{C}$; (2) transfer requirements apply to a TSC of the waste (after evaporation) in 241-AZ-102 to 241-AY-101 after addition of the proper amount of diluent over the temperature range of 25 to $65{ }^{\circ} \mathrm{C}$; and (3) transfer requirements apply to blend of 241-AZ-101 and 241-AZ-102 in 241-AY-101 to 241-AP-102 and 241-AP-104 over the temperature range of 25 to $65^{\circ} \mathrm{C}$.

Element 3, Mixing Requirements: N/A.

Element 4, Envelope and Quantity Requirements: there is one unique Batch 5 composition; the composition and physical properties are that of a whole tank blend of the waste which will be in 241-AY-101 (blend of AZ-101/102 diluted supernate and 241-AY-101 heel/sludge). The dilute heel in 241-AP-102 and -104 can be neglected for the purposes of this PSDQO (all current data strongly indicate that the 241-AP-102 and -104 heel will not interfere with staging the compositionally correct feed); how clean the tank needs to be is an operational issue, not a "Confirm Tank T..." issue.

Element 5, Miscellaneous Inputs: These inputs apply to the TSC of 241-AZ-101, 241-AZ-102, and blend of 241-AZ-101/102 diluted supernate with 241-AY-101 heel/sludge or to changes in the operating scenario that may be imposed in the future.

\section{Evaluate existing data and determine information needs.}

Table 1 contains the evaluation of the base case operating scenario for all the elements of the decision rules found in Section 6 of the PSDQO. The table lists each element taken from Section 4.0 of the PSDQO. For each element, the requirements specific to 241-AZ-101/ 241-AZ-102 / Batch 5 are listed. Each requirement is evaluated against existing data and the remaining information needs are identified. The information needs are summarized in Table 3.

\subsection{ALTERNATIVE CASE OPERATING SCENARIO}

Translate the operating scenario into a series of process steps.

The TWRSO\&UP (Kirkbride et al. 1997) recommended that process control issues be taken into account. This alternative case operating scenario was developed based on consideration of process control issues and is currently being evaluated and incorporated into the project master baseline schedule and corresponding logic diagrams. The steps that directly affect the composition of Batch 5 are listed below:

- Empty, flush, and empty 241-AP-102 and -104 (the feed staging tanks) leaving a dilute, $0.1 \mathrm{ML}$ (10-in.) heel behind in each tank. 
HNF-2799

Revision 0

- Mixer pump test in tank 241-AZ-101.

- Empty supernate from 241-AY-101 leaving supernate heel and sludge behind in each tank.

- Transfer supernate from 241-AZ-101 to 241-AY-101. During the transfer, the proper amount of diluent will be added to the waste at the transfer pump inlet.

- Transfer supernate from 241-AZ-102 to 241-AY-101 until 241-AY-101 is full . During the transfer, the proper amount of diluent will be added to the waste at the transfer pump inlet.

- Transfer supernate from 241-AY-101 to 241-AP-102 and -104.

The dilute heel in 241-AP-102 and -104 can be neglected for the purposes of this PSDQO; how clean the tank needs to be is an operational issue, not a "Confirm Tank T..." issue.

Define the waste that applies to each element in the decision rule.

Element 1, Dilution Ratio and Diluent Composition: this applies to the TSC of 241-AZ-101 and 241-AZ-102 over the temperature of $45^{\circ} \mathrm{C}$.

Element 2, Transfer Requirements: There are three transfers; (1) transfer requirements apply to a TSC of the waste in 241-AZ-101 to 241-AY-101 after addition of the proper amount of diluent over the temperature range of 25 to $65^{\circ} \mathrm{C}$; (2) transfer requirements apply to a TSC of the waste in 241-AZ-102 to 241-AY-101 after addition of the proper amount of diluent over the temperature range of 25 to $65^{\circ} \mathrm{C}$; and 3) transfer requirements apply to blend of 241-AZ-101 and 241-AZ-102 in 241-AY-101 to 241-AP-102 and 241-AP-104 over the temperature range of 25 to $65^{\circ} \mathrm{C}$.

Element 3, Mixing Requirements: N/A.

Element 4, Envelope and Quantity Requirements: there is one unique Batch 5 composition; the composition and physical properties are that of a whole tank blend of the waste which will be in 241-AY-101 (blend of AZ-101/102 diluted supernate and AY-101 heel/sludge). The dilute heel in 241-AP-102 and -104 can be neglected for the purposes of this PSDQO (all current data strongly indicate that the 241-AP-102 and -104 heel will not interfere with staging the compositionally correct feed); how clean the tank needs to be is an operational issue, not a "Confirm Tank T..." issue.

Element 5, Miscellaneous Inputs: These inputs apply to the TSC of 241-AZ-101, 241-AZ-102, and blend of 241-AZ-101/102 diluted supernate with 241-AY-101 heel/sludge or to changes in the operating scenario that may be imposed in the future. 
HNF-2799

Revision 0

Evaluate existing data and determine information needs.

Table 2 contains the evaluation of the alternative case operating scenario for all the elements of the decision rules found in Section 6 of the PSDQO. The table lists each element taken from Section 4.0 of the PSDQO. For each element, the requirements specific to 241-AZ-101/241-AZ-102 / Batch 5 are listed. Each requirement is evaluated against existing data and the remaining information needs are identified. The information needs are summarized in Table 3. 
Table 1. Base Case Operating Scenario Evaluation. (6 Sheets)

\begin{tabular}{|c|c|c|c|}
\hline Elements $^{a}$ & Requirements $^{b}$ & Discussion/evaluation & Information needs \\
\hline $\begin{array}{l}\text { Element } 1, \text { Dilution } \\
\text { Ratio and Diluent } \\
\text { Composition }\end{array}$ & $\begin{array}{l}\text { Determine the desired dilution ratio } \\
\text { and diluent composition for each } \\
\text { waste transfer. }\end{array}$ & $\begin{array}{l}\text { A test plan, based on instruction provided by the Disposal Program (Garfield } \\
\text { 1997), is need for process testing. The plan will obtain following information } \\
\text { for AZ-101 TSC, AZ-102 TSC and AZ-101/102 TSC blends: a) amount of } \\
\text { precipitation during evaporation to } 5 \mathrm{M} \mathrm{Na} \text { b) the minimum dilution ratio } \\
\text { after evaporation which satisfies all transfer system requirements except for } \\
\text { gibbsite formation; c) the maximum dilution ratio, beyond which gibbsite will } \\
\text { form at temperature ranges } 25^{\circ} \mathrm{C} \text { to } 65^{\circ} \mathrm{C} \text { or based on allowable tank } \\
\text { storage space consideration. } \\
\text { Dilution ration and Diluent composition will be established. }\end{array}$ & $\begin{array}{l}\text { Desired dilution } \\
\text { ratio and diluent } \\
\text { composition (See } \\
\text { Table 3, Item \# 1). }\end{array}$ \\
\hline \multirow[t]{3}{*}{$\begin{array}{l}\text { Element } 2 \text {, Transfer } \\
\text { Requirements }\end{array}$} & $\begin{array}{l}\text { Confirm that the as-retrieved waste } \\
\text { (including dilution water or caustic) } \\
\text { remains below saturation in major } \mathrm{Na} \\
\text { salts during the transfer to the staging } \\
\text { tank. }\end{array}$ & $\begin{array}{l}\text { A process test is needed to confirm that the as-retrieved waste (including } \\
\text { dilution water or caustic) remains below saturation in major Na salts during } \\
\text { the transfer to the staging tank. }\end{array}$ & $\begin{array}{l}\text { Confirm a dilution } \\
\text { ration of } 50 \% \text { for } \\
\text { the TSC is below } \\
\text { saturation in major } \\
\text { Na salts (See Table } \\
\text { 3, Item \# 2). }\end{array}$ \\
\hline & $\begin{array}{l}\text { Confirm that the as-retrieved waste } \\
\text { (including dilution water or caustic) } \\
\text { remain at or below viscosity of } \\
10 \mathrm{cP} \text {, at or below a } 1.5 \mathrm{SpG} \text {, and at } \\
\text { or below } 30 \text { percent solids by volume } \\
\text { during the transfer to the staging } \\
\text { tank. }\end{array}$ & $\begin{array}{l}\text { A process test is needed. The test will determine viscosity of the undiluted } \\
\text { TSCs, blend and at a } 50 \% \text { dilution ratio over the temperatures of } 25,45 \text {, and } \\
65{ }^{\circ} \mathrm{C} \text {. } \\
\text { A process test is needed. The largest observed quantity of settled solids for } \\
\text { TSCs and the blend dilution of } 50 \% \text { at temperatures of } 25,45 \text {, and } 65{ }^{\circ} \mathrm{C} \text { at } \\
48 \text { hours after mixing will be determined. } \\
\text { A process test is needed. The test will determine the liquid phase density for } \\
\text { TSCs and the blend dilution of } 50 \% \text { performed at temperatures of } 25,45 \text {, and } \\
65^{\circ} \mathrm{C} \text {. }\end{array}$ & $\begin{array}{l}\text { Determine viscosity, } \\
\text { SpG, suspended } \\
\text { solids (See Table 3, } \\
\text { Item \# 3). }\end{array}$ \\
\hline & $\begin{array}{l}\text { Confirm that the dilution ratio, } \\
\text { diluent composition, and waste } \\
\text { composition are balanced so gibbsite } \\
\text { or high viscosity slurries do not } \\
\text { precipitate }\end{array}$ & $\begin{array}{l}\text { An extended storage (at least one month) of supernate sub-samples from the } \\
\text { TSC dilution test at dilution ratio of } 0,40,80, \& 120 \% \text { and temperatures of } \\
25,45, \& 65^{\circ} \mathrm{C} \text { should be observed for solid formation. } \\
\text { Special Consideration: If gibbsite will form, it should form within four } \\
\text { weeks. }\end{array}$ & $\begin{array}{l}\text { Precipitation at } \\
0,40,80, \& 120 \% \\
\text { dilution ratios and at } \\
\text { temperatures of } 25, \\
45, \& 65^{\circ} \mathrm{C}(\text { See } \\
\text { Table } 3 \text {, Item \# } 4)\end{array}$ \\
\hline
\end{tabular}


Table 1. Base Case Operating Scenario Evaluation. (6 Sheets)

\begin{tabular}{|c|c|c|c|}
\hline Elements ${ }^{\mathrm{a}}$ & Requirements ${ }^{b}$ & Discussion/evaluation & Information needs \\
\hline $\begin{array}{l}\text { Element 3, Mixing } \\
\text { Requirements }\end{array}$ & N/A & N/A & N/A \\
\hline \multirow[t]{3}{*}{$\begin{array}{l}\text { Element } 4 \text { - Part 1: } \\
\text { Envelope } \\
\text { Requirements } \\
\text { These limits apply to } \\
\text { the feed actually } \\
\text { delivered to the } \\
\text { private contractors. }\end{array}$} & $\begin{array}{l}\text { Concentration limits for the chemical } \\
\text { and radionuclide content of the feed } \\
\text { (DOE-RL 1996, Section C.6). } \\
\text { See Section 2.0, Tables } 1 \text { and } 2 \text { (in } \\
\text { main report). }\end{array}$ & $\begin{array}{l}\text { Only Envelope B limits apply to Batch } 5 \text {. } \\
\text { The TWRSO\&UP (Kirkbride et al. 1997, Tables I-1 and I-3) compared the } \\
\text { point estimates }{ }^{1} \text { of the composition of the feed from } 241-A Z-101 / 241-A Z-102 \\
\text { to the Envelope limits and "flagged" sulfate as requiring further examination } \\
\text { for } 241-A Z-102 \text {. The sulfate was at } 111 \% \text { of the maximum limit of } 0.07 \\
\text { gmole sulfate/gmole Na; few other analytes were below } 80 \% \text { of their } \\
\text { maximum limits. Most analytes are missing. } \\
\text { The bulk supernate composition is needed. }\end{array}$ & $\begin{array}{l}\text { Chemical and } \\
\text { radionuclide } \\
\text { analyses from tests } \\
\text { (See Table 3, } \\
\text { Item \# 5). }\end{array}$ \\
\hline & $\begin{array}{l}\text { Concentration limit for the sodium } \\
\text { concentration of the feed: } \\
3 \underline{M} \leq[N a] \leq 14 \underline{M} \text { (DOE-RL 1996, } \\
\text { Section C.6). }\end{array}$ & During a process test [Na] will be measured. & $\begin{array}{l}\text { [Na] measurement } \\
\text { (See Table 3, } \\
\text { Item \# 6). }\end{array}$ \\
\hline & $\begin{array}{l}\text { Insoluble solids fraction limit will } \\
\text { not exceed } 5 \text { volume } \% \text { (DOE-RL } \\
\text { 1996, Section C.6). }\end{array}$ & $\begin{array}{l}\text { The contracts do not define how the volume percent insoluble solids will be } \\
\text { measured. } \\
\text { During the process test, measurement will made to measure the quantity of } \\
\text { solids for TSC dilution of } 50 \% \text { at temperature of } 45^{\circ} \mathrm{C} \text {. }\end{array}$ & $\begin{array}{l}\text { Insoluble solids } \\
\text { measurement (See } \\
\text { Table 3, Item \# 7). }\end{array}$ \\
\hline
\end{tabular}

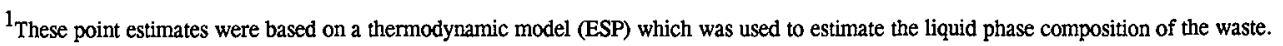


Table 1. Base Case Operating Scenario Evaluation. (6 Sheets)

\begin{tabular}{|c|c|c|c|}
\hline Elements $^{\mathrm{a}}$ & Requirements $^{\mathbf{b}}$ & Discussion/evaluation & Information needs \\
\hline $\begin{array}{l}\text { Element } 4 \text { - Part 1: } \\
\text { Envelope } \\
\text { Requirements } \\
\text { (continued) }\end{array}$ & $\begin{array}{l}\text { Operating Specifications from } \\
\text { OSD-T-151-00007 (DOE-RL 1996, } \\
\text { Section C.6 invokes the OSD by } \\
\text { reference). } \\
\text { See Section 2.0, Table } 3 \text { (in main } \\
\text { report). }\end{array}$ & $\begin{array}{l}\text { The contract does not explicitly state which specifications from the OSD } \\
\text { apply to the waste. The PHMC assumes that the Tank Composition (7.2.1) } \\
\text { and Heat Generation Rate (7.2.8) limits apply to the waste. These limits are } \\
\text { shown in Section } 2.0 \text {, Table } 3 \text { (in main report). } \\
\text { The TWRSO\&UP (Kirkbride et al. 1997, Section } 3.1 .1 .6 \text { ) compared the } \\
\text { point estimates of the composition of the waste as staged in } 241-A P-102 \text { and - } \\
104 \text { with the Tank Composition (Tank Corrosion) specifications. All limits } \\
\text { were satisfied for Batch 5. Uncertainty is not an issue since the [OH], [NO } 2 \text { ] } \\
\text { and [NO }{ }_{3} \text { ] in the staging tanks can be adjusted if needed before the feed } \\
\text { qualification samples are taken. } \\
\text { The TWRSO\&UP (Section } 3.1 .1 .6 \text { ) also evaluated the heat generation rate } \\
\text { rule and found that all limits were satisfied for Batch } 5 \text {, decayed to the } \\
\text { estimated time of delivery. The estimated heat generation rate for Batch } 5 \text { is } \\
25,400 \text { BTU/hr. This is well within the maximum limit of } 70,000 \text { BTU/hr. } \\
\text { The tank characterization report estimates the heat load of supernate in } \\
241-A Z-101 \text { (Hodgson } 1995 \text { ) to be } 89,600 \text { BTU/hr. From the tank } \\
\text { characterization report, an estimated heat load in supernate in } 241-A Z-102 \\
\text { (Ryan } 1995 \text { ) is } 45,000 \text { Btu/hr. Therefore the estimated heat generation rate } \\
\text { for Batch } 5 \text { is 77,500 Btu/hr (assume only } 25 \% \text { of AZ-102 supernate } \\
\text { transferred). This estimate is over the maximum limit. Comparing heat load } \\
\text { of the feed from } 241-A Z-101 / 241-A Z-102 \text { to the Envelope limits the heat } \\
\text { load is "flagged" as requiring further examination for } 241-A Z-101 / 241-A Z \text { - } \\
102 \text {. This estimate is conservative since it does not take into account the } \\
\text { additional decay that will take place before delivery of the feed Batch. } \\
\text { Conformance with OSD factors is not achieved. During the process testing, } \\
\text { full analysis is needed for Envelope B including } 137 \text { Cs. }\end{array}$ & $\begin{array}{l}\text { During the process } \\
\text { testing, full analysis } \\
\text { is needed for } \\
\text { Envelope } \mathrm{B} \\
\text { including }{ }^{137} \mathrm{Cs} \text { (See } \\
\text { Table 3, Item \# 8). }\end{array}$ \\
\hline
\end{tabular}


Table 1. Base Case Operating Scenario Evaluation. (6 Sheets)

\begin{tabular}{|c|c|c|c|}
\hline Elements $^{\mathbf{a}}$ & Requirements $^{\mathrm{b}}$ & Discussion/evaluation & Information needs \\
\hline \multirow[t]{2}{*}{$\begin{array}{l}\text { Element } 4 \text { - Part 1: } \\
\text { Envelope } \\
\text { Requirements } \\
\text { (continued) }\end{array}$} & $\begin{array}{l}\text { Maximum }{ }^{137} \mathrm{Cs} \text { concentration of } \\
5.86 \mathrm{E} 10 \mathrm{~Bq} / \text { liter }(6 \mathrm{Ci} / \mathrm{gal}) \text {. }\end{array}$ & $\begin{array}{l}\text { This limit is equivalent to } 1.59 \mathrm{E} 6 \mu \mathrm{Ci} / \mathrm{L} \text {. The } \mathrm{OSD} \text { limit of } 5.74 \mathrm{E} 5 \mu \mathrm{Ci} / \mathrm{L} \text { is } \\
\text { more restrictive. } \\
\text { The tank characterization report estimates the }{ }^{137} \mathrm{Cs} \text { concentration of } \\
\text { supernate in } 241-\mathrm{AZ}-101 \text { (Hodgson } 1995 \text { ) to be } 1.59 \mathrm{E} 6 \mu \mathrm{Ci} / \mathrm{L} \text {. From the tank } \\
\text { characterization report, an estimated }{ }^{137} \mathrm{Cs} \text { concentration in supernate in } 241- \\
\text { AZ-102 (Ryan } 1995 \text { ) } 8.6 \mathrm{E} 5 \mu \mathrm{Ci} / \mathrm{L} \text {. Therefore the estimated }{ }^{137} \mathrm{Cs} \\
\text { concentration for Batch } 5 \text { is } 1.42 \mathrm{E} 6 \mu \mathrm{Ci} / \mathrm{L} \text {. This estimate is over the } \\
\text { maximum limit. Comparing }{ }^{137} \mathrm{Cs} \text { concentration of the feed from } 241-\mathrm{AZ} \text { - } \\
101 / 241-\mathrm{AZ}-102 \text { to the OSD limit the }{ }^{137} \mathrm{Cs} \text { concentration is "flagged" as } \\
\text { requiring further examination for } 241-\mathrm{AZ}-101 / 241 \text {-AZ-102. This estimate is } \\
\text { conservative since it does not take into account the additional decay that will } \\
\text { take place before delivery of the feed Batch. } \\
\text { The tank characterization report estimates the }{ }^{90} \mathrm{Sr} \text { concentration of supernate } \\
\text { in } 241-\mathrm{AZ}-101 \text { (Hodgson } 1995 \text { ) to be } 1,200 \mu \mathrm{Ci} / \mathrm{L} \text {. From the tank } \\
\text { characterization report, an estimated }{ }^{90} \mathrm{Sr} \text { concentration in supernate in } 241- \\
\text { AZ-102 (Ryan } 1995 \text { ) } 1,450 \mu \mathrm{Ci} / \mathrm{L} \text {. Therefore the estimated }{ }^{90} \mathrm{Sr} \\
\text { concentration for Batch } 5 \text { is } 1,260 \mu \mathrm{Ci} / \mathrm{L} \text {. This estimate is well below the } \\
\text { maximum limit. This estimate is conservative since it does not take into } \\
\text { account the additional decay that will take place before delivery of the feed } \\
\text { Batch. } \\
\text { Conformance with OSD factors is not achieved. During the process testing, } \\
\text { analysis is needed for }{ }^{137} \mathrm{Cs} \text {. }\end{array}$ & $\begin{array}{l}\text { During the process } \\
\text { testing, analysis is } \\
\text { needed for }{ }^{137} \mathrm{Cs} \\
\text { (See Table } 3 \text {, } \\
\text { Item \# 8). }\end{array}$ \\
\hline & $\begin{array}{l}\text { The PHMC assumed minimum limits } \\
\text { to distinguish between Envelope } A \\
\text { and } \mathrm{C} \text { and between Envelopes } \mathrm{A} \text { and } \\
\mathrm{B}\end{array}$ & $\begin{array}{l}\text { The discriminator is sulfate for Batch } 5 \text { (Envelope B). } \\
\text { Sulfate concentration is needed. }\end{array}$ & $\begin{array}{l}\text { Determine sulfate } \\
\text { concentration (See } \\
\text { Table 3, Item \# 9). }\end{array}$ \\
\hline \multirow[t]{2}{*}{$\begin{array}{l}\text { Element } 4 \text { - Part 2: } \\
\text { Quantity } \\
\text { Requirements }\end{array}$} & $\begin{array}{l}\text { Batch size (mass of sodium) } \\
\text { constraints (from the contracts) } \geq 100 \\
\text { MT Na. }\end{array}$ & $\begin{array}{l}\text { During process test, amount of } \mathrm{Na} \text { recoverable will be measured at } 50 \% \\
\text { dilution ratio }\end{array}$ & $\begin{array}{l}\text { Determine Na } \\
\text { quantity (See Table } \\
\text { 3, Item \# 10). }\end{array}$ \\
\hline & $\begin{array}{l}\text { PHMC targeted batch size range } \\
\text { (from the ICD (PHMC 1997, } \\
\text { Table 3D): } 100-250 \text { MT Na. }\end{array}$ & Same as above. & $\begin{array}{l}\text { Determine Na } \\
\text { quantity (See Table } \\
3 \text {, Item \# 10). }\end{array}$ \\
\hline
\end{tabular}


Table 1. Base Case Operating Scenario Evaluation. (6 Sheets)

\begin{tabular}{|c|c|c|c|}
\hline Elements ${ }^{\mathrm{a}}$ & Requirements $^{b}$ & Discussion/evaluation & Information needs \\
\hline $\begin{array}{l}\text { Element } 4 \text { - Part } 2 \text { : } \\
\text { Quantity } \\
\text { Requirements } \\
\text { (Continued) }\end{array}$ & $\begin{array}{l}\text { PHMC desired batch size (from } \\
\text { Operating Scenario): } 118 \mathrm{MT} \text { Na } \\
\text { (Kirkbride et al. 1997, Table 3.1-5) }\end{array}$ & Same as above. & $\begin{array}{l}\text { Determine } \mathrm{Na} \\
\text { quantity (See Table } \\
\text { 3, Item \# 10). }\end{array}$ \\
\hline \multirow[t]{4}{*}{$\begin{array}{l}\text { Element } 5 \text { - } \\
\text { Miscellaneous Inputs }\end{array}$} & Physical form of Tank $\mathrm{T}$ contents & $\begin{array}{l}\text { From Hanlon (1998): } 241-A Z-101 \text { has approximately } 7.7 \mathrm{~m} \text { ( } 25.8 \mathrm{ft}) \text { of } \\
\text { supernate which is compositionally homogenous. There are approximately } \\
43 \mathrm{~cm}(17 \mathrm{in} \text {.) of sludge. } 241-\mathrm{AZ}-102 \text { has approximately } 7.2 \mathrm{~m}(23.5 \mathrm{ft}) \text { of } \\
\text { supernate which is compositionally homogenous. There are approximately } \\
96 \mathrm{~cm} \text { ( } 38 \mathrm{in} \text {.) of sludge }\end{array}$ & $\begin{array}{l}\text { No further } \\
\text { information is } \\
\text { needed }\end{array}$ \\
\hline & $\begin{array}{l}\text { Heel from prior batch remaining in } \\
\text { staging tanks }\end{array}$ & $\begin{array}{l}10 \text {-in. supernate heels and sludge remaining in } 241-\mathrm{AY}-101 \text { need to be } \\
\text { addressed. Heels remaining from clean out of } 241-\mathrm{AP}-102 \text { and }-104 \text { are } \\
\text { addressed in Section } 2.1 \text { above. }\end{array}$ & $\begin{array}{l}\text { Process test needed } \\
\text { (see Table } 3 \text {, Item } \\
\text { \#11) }\end{array}$ \\
\hline & Shimming Batch 5 & No shimming is anticipated. & $\begin{array}{l}\text { No further } \\
\text { information is } \\
\text { needed }\end{array}$ \\
\hline & RL direction & No changes to applicable M\&I ICD requirements have been made to date. & $\begin{array}{l}\text { No further } \\
\text { information is } \\
\text { needed }\end{array}$ \\
\hline
\end{tabular}

a. Elements are taken from the Decision Rule statement in Section 4.0 of PSDQO-01.

b. Requirements are taken from Sections $4.1,4.2,4.3,4.4$, and 4.5 of PSDQO-01. 
Table 2. Alternative Case Operating Scenario Evaluation. (4 Sheets)

\begin{tabular}{|c|c|c|c|}
\hline Elements $^{\mathrm{a}}$ & Requirements $^{\mathrm{b}}$ & Discussion/evaluation & Information needs \\
\hline $\begin{array}{l}\text { Element 1, Dilution } \\
\text { Ratio and Diluent } \\
\text { Composition }\end{array}$ & $\begin{array}{l}\text { Determine the desired dilution ratio } \\
\text { and diluent composition for each } \\
\text { waste transfer. }\end{array}$ & $\begin{array}{l}\text { A test plan, based on instruction provided by the Disposal Program } \\
\text { (Garfield 1997), is need for process testing. The plan will obtain } \\
\text { following information for AZ-101 TSC, AZ-102 TSC and AZ-101/102 } \\
\text { TSC blends: a) the minimum dilution ratio which satisfies all transfer } \\
\text { system requirements except for gibbsite formation; b) the maximum } \\
\text { dilution ratio, beyond which gibbsite will form at temperature ranges } \\
25^{\circ} \mathrm{C} \text { to } 65^{\circ} \mathrm{C} \text { or based on allowable tank storage space consideration. } \\
\text { Dilution ration and Diluent composition will be established. }\end{array}$ & $\begin{array}{l}\text { Desired dilution ratio } \\
\text { and diluent } \\
\text { composition(See } \\
\text { Table 3, Item \# 12) }\end{array}$ \\
\hline \multirow[t]{2}{*}{$\begin{array}{l}\text { Element } 2 \text {, Transfer } \\
\text { Requirements are } \\
\text { Satisfied }\end{array}$} & $\begin{array}{l}\text { Confirm that the as-retrieved waste } \\
\text { (including dilution water or caustic) } \\
\text { remains below saturation in major } \\
\text { Na salts during the transfer to the } \\
\text { staging tank. }\end{array}$ & $\begin{array}{l}\text { A process test is needed to confirm that the as-retrieved waste } \\
\text { (including dilution water or caustic) remains below saturation in major } \\
\text { Na salts during the transfer to the staging tank. }\end{array}$ & $\begin{array}{l}\text { Confirm a dilution } \\
\text { ration of } 50 \% \text { for the } \\
\text { TSC is below } \\
\text { saturation in major } \\
\text { Na salts (See Table 3, } \\
\text { Item \# 13). }\end{array}$ \\
\hline & $\begin{array}{l}\text { Confirm that the as-retrieved waste } \\
\text { (including dilution water or caustic) } \\
\text { remain at or below viscosity of } \\
10 \mathrm{cP} \text {, at or below a } 1.5 \mathrm{SpG} \text {, and at } \\
\text { or below } 30 \text { percent solids by } \\
\text { volume during the transfer to the } \\
\text { staging tank. }\end{array}$ & $\begin{array}{l}\text { A process test is needed. The test will determine viscosity of the } \\
\text { undiluted TSCs, blend and at a } 50 \% \text { dilution ratio over the temperatures } \\
\text { of } 25,45 \text {, and } 65^{\circ} \mathrm{C} \text {. } \\
\text { A process test is needed. The largest observed quantity of settled solids } \\
\text { for TSCs and the blend dilution of } 50 \% \text { at temperatures of } 25,45 \text {, and } \\
65^{\circ} \mathrm{C} \text { at } 48 \text { hours after mixing will be determined. } \\
\text { A process test is needed. The test will determine the liquid phase } \\
\text { density for TSCs and the blend dilution of } 50 \% \text { performed at } \\
\text { temperanures of } 25,45 \text {, and } 65^{\circ} \mathrm{C} \text {. }\end{array}$ & $\begin{array}{l}\text { Determine viscosity, } \\
\text { SpG, suspended } \\
\text { solids (See Table } 3 \text {, } \\
\text { Item \# 14). }\end{array}$ \\
\hline
\end{tabular}


Table 2. Alternative Case Operating Scenario Evaluation. (4 Sheets)

\begin{tabular}{|c|c|c|c|}
\hline Elements ${ }^{\mathbf{a}}$ & Requirements $^{\mathrm{b}}$ & Discussion/evaluation & Information needs \\
\hline $\begin{array}{l}\text { Element 2, Transfer } \\
\text { Requirements are } \\
\text { Satisfied (continued) }\end{array}$ & $\begin{array}{l}\text { Confirm that the dilution ratio, } \\
\text { diluent composition, and waste } \\
\text { composition are balanced so gibbsite } \\
\text { or high viscosity slurries do not } \\
\text { precipitate. }\end{array}$ & $\begin{array}{l}\text { An extended storage (at least one month) of supernate sub-samples } \\
\text { from the TSC dilution test at dilution ratio of } 0,40,80, \& 120 \% \text { and } \\
\text { temperatures of } 25,45, \& 65^{\circ} \mathrm{C} \text { should be observed for solid } \\
\text { formation. } \\
\text { Special Consideration: If gibbsite will form, it should form within four } \\
\text { weeks. }\end{array}$ & $\begin{array}{l}\text { Precipitation at } 0,40, \\
80, \& 120 \% \text { dilution } \\
\text { ratios and at } \\
\text { temperatures of } 25, \\
45, \& 65^{\circ} \mathrm{C} \text { (See } \\
\text { Table 3, Item \# } 15 \text { ). }\end{array}$ \\
\hline $\begin{array}{l}\text { Element 3, Mixing } \\
\text { Requirements }\end{array}$ & N/A & $\mathrm{N} / \mathrm{A}$ & N/A \\
\hline \multirow[t]{2}{*}{$\begin{array}{l}\text { Element } 4 \text { - Part 1: } \\
\text { Envelope } \\
\text { Requirements } \\
\text { These limits apply to } \\
\text { the feed actually } \\
\text { delivered to the } \\
\text { private contractors. }\end{array}$} & $\begin{array}{l}\text { Concentration limits for the } \\
\text { chemical and radionuclide content of } \\
\text { the feed (DOE-RL 1996, } \\
\text { Section C.6). } \\
\text { See Section 2.0, Tables } 1 \text { and } 2 \text { (in } \\
\text { main report) for the limits. }\end{array}$ & $\begin{array}{l}\text { Only Envelope B limits apply to Batch } 5 \text {. } \\
\text { The TWRSO\&UP (Kirkbride et al. 1997, Tables I-1 and I-3) compared } \\
\text { the point estimates }{ }^{1} \text { of the composition of the feed from } 241-\mathrm{AZ} \text { - } \\
101 / 241-\mathrm{AZ}-102 \text { to the Envelope limits and "flagged" sulfate as } \\
\text { requiring further examination for } 241-\mathrm{AZ}-102 \text {. The sulfate was at } \\
111 \% \text { of the maximum limit of } 0.07 \text { gmole sulfate/gmole Na; Few other } \\
\text { analytes were below } 80 \% \text { of their maximum limits. Most analytes are } \\
\text { missing. } \\
\text { The bulk supernate composition is needed. }\end{array}$ & $\begin{array}{l}\text { Chemical and } \\
\text { radionuclide analyses } \\
\text { from precess testing } \\
\text { (See Table } 3 \text {, } \\
\text { Item \# 16). }\end{array}$ \\
\hline & $\begin{array}{l}\text { Concentration limit for the sodium } \\
\text { concentration of the feed: } \\
3 \mathrm{M} \leq[\mathrm{Na}] \leq 14 \mathrm{M} \text { (DOE-RL } \\
1996 \text {, Section C.6). }\end{array}$ & During a process test [Na] will be measured. & $\begin{array}{l}\text { [Na] measurement } \\
\text { (See Table 3, } \\
\text { Item \# 16). }\end{array}$ \\
\hline
\end{tabular}

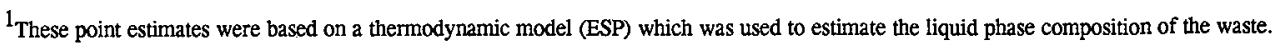


Table 2. Alternative Case Operating Scenario Evaluation. (4 Sheets)

\begin{tabular}{|c|c|c|c|}
\hline Elements ${ }^{\mathrm{a}}$ & Requirements $^{b}$ & Discussion/evaluation & Information needs \\
\hline \multirow[t]{2}{*}{$\begin{array}{l}\text { Element } 4 \text { - Part 1: } \\
\text { Envelope } \\
\text { Requirements } \\
\text { (continued) }\end{array}$} & $\begin{array}{l}\text { Insoluble solids fraction limit will } \\
\text { not exceed } 5 \text { volume } \% \text { (DOE-RL } \\
\text { 1996, Section C.6). }\end{array}$ & $\begin{array}{l}\text { The contracts do not define how the volume percent insoluble solids } \\
\text { will be measured. } \\
\text { During the process test, measurement will made to measure the quantity } \\
\text { of solids for TSC dilution of } 50 \% \text { at temperature of } 45^{\circ} \mathrm{C} \text {. }\end{array}$ & $\begin{array}{l}\text { Insoluble solids } \\
\text { measurement (See } \\
\text { Table 3, Item \# 18). }\end{array}$ \\
\hline & $\begin{array}{l}\text { Operating Specifications from } \\
\text { OSD-T-151-00007 (DOE-RL 1996, } \\
\text { Section C.6 invokes the OSD by } \\
\text { reference). } \\
\text { See Section } 2.0 \text {, Table } 3 \text { (in main } \\
\text { report). }\end{array}$ & 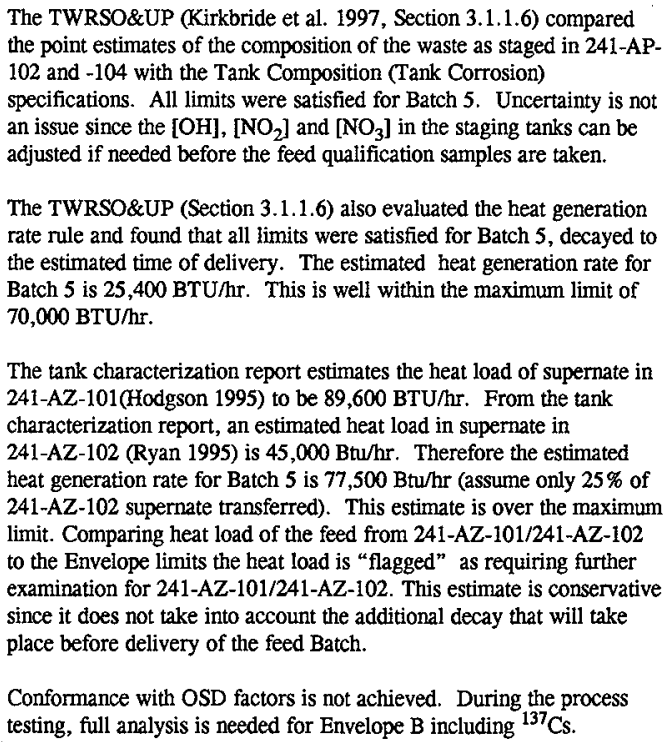 & $\begin{array}{l}\text { During the process } \\
\text { testing, full analysis } \\
\text { is needed for } \\
\text { Envelope B including } \\
{ }^{137} \mathrm{Cs} \text {.(See Table } 3 \text {, } \\
\text { Item \# 19). }\end{array}$ \\
\hline
\end{tabular}


Table 2. Alternative Case Operating Scenario Evaluation. (4 Sheets)

\begin{tabular}{|c|c|c|c|}
\hline Elements $^{\mathrm{a}}$ & Requirements $^{b}$ & Discussion/evaluation & Information needs \\
\hline \multirow[t]{2}{*}{$\begin{array}{l}\text { Element } 4 \text { - Part 1: } \\
\text { Envelope } \\
\text { Requirements } \\
\text { (continued) }\end{array}$} & $\begin{array}{l}\text { Maximum }{ }^{137} \mathrm{Cs} \text { concentration of } \\
5.86 \mathrm{E} 10 \mathrm{~Bq} / \mathrm{liter}(6 \mathrm{Ci} / \mathrm{gal}) \text {. } \\
\text { Maximum }{ }^{90} \mathrm{Sr} \text { concentration of } \\
4.04 \mathrm{E} \mu \mathrm{Ci} / \mathrm{L} \text {. }\end{array}$ & $\begin{array}{l}\text { This limit is equivalent to } 1.59 \mathrm{E} 6 \mu \mathrm{Ci} / \mathrm{L} \text {. The OSD limit of } 5.74 \mathrm{E} 5 \\
\mu \mathrm{Ci} / \mathrm{L} \text { is more restrictive. } \\
\text { The tank characterization report estimates the }{ }^{137} \mathrm{Cs} \text { concentration of } \\
\text { supernate in } 241-\mathrm{AZ}-101 \text { (Hodgson } 1995 \text { ) to be } 1.59 \mathrm{E} 6 \mu \mathrm{Ci} / \mathrm{L} \text {. From } \\
\text { the tank characterization report, an estimated }{ }^{137} \mathrm{Cs} \text { concentration in } \\
\text { supernate in } 241-\mathrm{AZ}-102 \text { (Ryan } 1995) 8.6 \mathrm{E} 5 \mu \mathrm{Ci} / \mathrm{L} \text {. Therefore the } \\
\text { estimated }{ }^{137} \mathrm{Cs} \text { concentration for Batch } 5 \text { is } 1.42 \mathrm{E} 6 \mu \mathrm{Ci} / \mathrm{L} \text {. This } \\
\text { estimate is over the maximum limit. Comparing }{ }^{137} \mathrm{Cs} \text { concentration of } \\
\text { the feed from } 241-\mathrm{AZ}-101 / 241-\mathrm{AZ}-102 \text { to the OSD limit the }{ }^{137} \mathrm{Cs} \\
\text { concentration is "flagged" as requiring further examination for } \\
241-\mathrm{AZ}-101 / 241-\mathrm{AZ}-102 \text {. This estimate is conservative since it does not } \\
\text { take into account the additional decay that will take place before } \\
\text { delivery of the feed Batch. } \\
\text { The tank characterization report estimates the }{ }^{90} \mathrm{Sr} \text { concentration of } \\
\text { supernate in } 241-\mathrm{AZ}-101 \text { (Hodgson } 1995 \text { ) to be } 1,200 \mu \mathrm{Ci} / \mathrm{L} \text {. From the } \\
\text { tank characterization report, an estimated } 90 \mathrm{Sr} \text { concentration in } \\
\text { supernate in } 241-\mathrm{AZ}-102 \text { (Ryan } 1995 \text { ) } 1,450 \mu \mathrm{Ci} / \mathrm{L} \text {. Therefore the } \\
\text { estimated }{ }^{90} \mathrm{Sr} \text { concentration for Batch } 5 \text { is } 1,260 \mu \mathrm{Ci} / \mathrm{L} \text {. This estimate } \\
\text { is well below the maximum limit. This estimate is conservative since it } \\
\text { does not take into account the additional decay that will take place } \\
\text { before delivery of the feed Batch. } \\
\text { Conformance with OSD factors is not achieved. During the process } \\
\text { testing, analysis is needed for }{ }^{137} \mathrm{Cs} \text {. }\end{array}$ & $\begin{array}{l}\text { During the process } \\
\text { testing, analysis is } \\
\text { needed for }{ }^{37} \mathrm{Cs} \text {. } \\
\text { (See Table 3, Item } \\
\# 19 .)\end{array}$ \\
\hline & $\begin{array}{l}\text { The PHMC assumed minimum } \\
\text { limits to distinguish between } \\
\text { Envelope } A \text { and } C \text { and between } \\
\text { Envelopes } A \text { and } B\end{array}$ & $\begin{array}{l}\text { These discriminators do not apply to Batch } 5 \text { (Envelope A). } \\
\text { No concern about distinguishing between envelopes. }\end{array}$ & $\begin{array}{l}\text { Determine sulfate. } \\
\text { concentration. }\end{array}$ \\
\hline $\begin{array}{l}\text { Element } 4 \text { - Part } 2 \text { : } \\
\text { Quantity } \\
\text { Requirements are } \\
\text { Satisfied }\end{array}$ & $\begin{array}{l}\text { Batch size (mass of sodium) } \\
\text { constraints (from the contracts) } 2 \\
100 \mathrm{MT} \mathrm{Na} \text {. }\end{array}$ & $\begin{array}{l}\text { During the process test, amount of Na recoverable will be measured at } \\
50 \% \text { dilution ratio. }\end{array}$ & $\begin{array}{l}\text { Determine Na } \\
\text { quantity (See Table } 3 \text {, } \\
\text { Item \# 17). }\end{array}$ \\
\hline
\end{tabular}


Table 2. Alternative Case Operating Scenario Evaluation. (4 Sheets)

\begin{tabular}{|c|c|c|c|}
\hline Elements $^{\mathrm{a}}$ & Requirements $^{\mathrm{b}}$ & Discussion/evaluation & Information needs \\
\hline \multirow{2}{*}{$\begin{array}{l}\text { Element } 4 \text { - Part } 2 \text { : } \\
\text { Quantity } \\
\text { Requirements are } \\
\text { Satisfied (continued) }\end{array}$} & $\begin{array}{l}\text { PHMC targeted batch size range } \\
\text { (from the ICD (PHMC 1997, } \\
\text { Table 3D): } 100-250 \text { MT Na. }\end{array}$ & Same as above. & $\begin{array}{l}\text { Determine } \mathrm{Na} \\
\text { quantity (See Table } 3 \text {, } \\
\text { Item \# 17). }\end{array}$ \\
\hline & $\begin{array}{l}\text { PHMC desired batch size (from } \\
\text { Operating Scenario): } 118 \text { MT Na } \\
\text { (Kirkbride et al. 1997, Table 3.1-5) }\end{array}$ & Same as above. & $\begin{array}{l}\text { Determine Na } \\
\text { quantity (See Table 3, } \\
\text { Item \# 17). }\end{array}$ \\
\hline \multirow[t]{4}{*}{$\begin{array}{l}\text { Element } 5 \text { - } \\
\text { Miscellaneous Inputs }\end{array}$} & Physical form of Tank $T$ contents & $\begin{array}{l}\text { From Hanlon (1998): } 241-\mathrm{AZ}-101 \text { has approximately } 7.7 \mathrm{~m} \text { ( } 25.8 \mathrm{ft}) \text { of } \\
\text { supernate which is compositionally homogenous. There are } \\
\text { approximately } 43 \mathrm{~cm} \text { (17 inches) of sludge. } 241-\mathrm{AZ}-102 \text { has } \\
\text { approximately } 7.2 \mathrm{~m} \text { ( } 23.5 \mathrm{ft} \text { ) of supernate which is compositionally } \\
\text { homogenous. There are approximately } 96 \mathrm{~cm} \text { ( } 38 \text { inches) of sludge. }\end{array}$ & $\begin{array}{l}\text { No further } \\
\text { information is needed }\end{array}$ \\
\hline & $\begin{array}{l}\text { Heel from prior batch remaining in } \\
\text { staging tanks }\end{array}$ & $\begin{array}{l}10 " \text { supernate heels and sludge remaining in } 241-\mathrm{AY}-101 \text { need to be } \\
\text { addressed. Heels remaining from clean out of } 241-\mathrm{AP}-102 \text { and -104 } \\
\text { are addressed in Section } 2.1 \text { above }\end{array}$ & $\begin{array}{l}\text { Process test needed. } \\
\text { (See Table 3, Item } \\
\text { 20) }\end{array}$ \\
\hline & Shimming Batch 5 & No shimming is anticipated. & $\begin{array}{l}\text { No further } \\
\text { information is needed }\end{array}$ \\
\hline & RL direction & $\begin{array}{l}\text { No changes to applicable M\&I ICD requirements have been made to } \\
\text { date. }\end{array}$ & $\begin{array}{l}\text { No further } \\
\text { information is needed }\end{array}$ \\
\hline
\end{tabular}

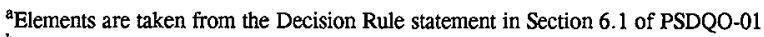

${ }^{\mathrm{b}}$ Requirements are taken from Sections 4.1, 4.2, 4.3, 4.4, and 4.5 of PSDQO-01. 


\section{Revision 0}

Table 3 was developed jointly by TWRS Characterization and Tank Waste Retrieval. It is intended to show what information is still needed, what can be obtained by calculations with existing data, what requires new (or existing) samples, analysis and/or process testing. Where samples are required, the amount and "representativeness" of the sample will be stated. Where analysis is needed, the specific analytes and QA requirements will be stated. If process testing is needed, the amount of sample and goals of the process test will be stated.

Appropriate level of end description of QA requirements will be covered in the specific work plan for these limited process tests.

Table 3. Information Needs. (2 Sheets)

\begin{tabular}{|c|c|c|c|}
\hline Item & Information need & Planned resolution & Sample required \\
\hline 1 & $\begin{array}{l}\text { Desired dilution } \\
\text { ratio and diluent } \\
\text { composition }\end{array}$ & $\begin{array}{l}\text { Perform lab test: Measure amount of precipitation during } \\
\text { evaporation to } 5 \mathrm{M} \mathrm{Na} \text {; measure minimum dilution ratio } \\
\text { which satisfies all transfer system; measure maximum } \\
\text { dilution ratio where gibbsite will not become a problem. } \\
\text { Determine desired dilution ratio and diluent. }\end{array}$ & $\begin{array}{l}250 \mathrm{ml} 241-\mathrm{AZ}-101 \\
\text { TSC, 250 ml } \\
\text { 241-AZ-102 TSC, } \\
\text { 241-AY-101 sludge, } \\
\text { 241-AY-101 } \\
\text { supernate }\end{array}$ \\
\hline 2 & $\begin{array}{l}\text { Confirm a dilution } \\
\text { ratio of } 50 \% \text { for the } \\
\text { ISC and blend is } \\
\text { below saturation in } \\
\text { major Na salts }\end{array}$ & $\begin{array}{l}\text { Perform lab test: to confirm that the as retrieved waste } \\
\text { remain below saturation in major Na salts during the } \\
\text { transfer to the staging tanks }\end{array}$ & $\begin{array}{l}250 \mathrm{ml} 241-\mathrm{AZ}-101 \\
\text { TSC, } 250 \mathrm{ml} \\
241-\mathrm{AZ}-102 \text { TSC, } \\
\text { 241-AY-101 sludge, } \\
\text { 241-AY-101 } \\
\text { supernate }\end{array}$ \\
\hline 3 & $\begin{array}{l}\text { Determine viscosity, } \\
\text { SpG, suspended } \\
\text { solids }\end{array}$ & $\begin{array}{l}\text { Perform lab test to determine viscosity, SpG, suspended } \\
\text { solids }\end{array}$ & $\begin{array}{l}\text { Use sample from } \\
\text { Item } \# 2 \text {. }\end{array}$ \\
\hline 4 & $\begin{array}{l}\text { Determine solid } \\
\text { formation, if any }\end{array}$ & $\begin{array}{l}\text { An extenced storage of supernate sub-samples from the } \\
\text { TSC dilution test at dilution ratio up to } 120 \% \text {. }\end{array}$ & $\begin{array}{l}250 \mathrm{ml} \text { 241-AZ-101 } \\
\text { TSC, 250 ml } \\
\text { 241-AZ-102 TSC, } \\
\text { 241-AY-101 sludge, } \\
\text { 241-AY-101 } \\
\text { supernate }\end{array}$ \\
\hline 5 & $\begin{array}{l}\text { Chemical and } \\
\text { radionuclide } \\
\text { analyses. }\end{array}$ & $\begin{array}{l}\text { Measure the analytes in Section } 2.0 \text {, Tables } 1 \text { and } 2 \text { (in } \\
\text { main report) (Envelope B analytes). Determine the bulk } \\
\text { supernate composition. }\end{array}$ & $50 \mathrm{ml}$ of blend \\
\hline 6 & [Na] measurement & Measurement of [Na] can be obtained from item \#5. & None \\
\hline 7 & $\begin{array}{l}\text { Confirm insoluble } \\
\text { solids fraction limit } \\
\text { will not exceed } 5 \\
\text { volume \%. }\end{array}$ & Measurement of solid in the blend. & $50 \mathrm{ml}$ of blend. \\
\hline 8 & $\begin{array}{l}\text { Operating } \\
\text { Specification } \\
\text { requirements }\end{array}$ & $\begin{array}{l}\text { Perform lab test; Analysis of chemical and radionuclides } \\
\text { can be obtained by results from item } \# 5 \text {. }\end{array}$ & None \\
\hline 9 & $\begin{array}{l}\text { Determine sulfate } \\
\text { concentration as a } \\
\text { discriminator for } \\
\text { Envelope B. }\end{array}$ & $\begin{array}{l}\text { Perform lab test; Analysis of sulfate can be obtained by } \\
\text { results from item } \# 5 \text {. }\end{array}$ & None \\
\hline
\end{tabular}


Table 3. Information Needs. (2 Sheets)

\begin{tabular}{|c|c|c|c|}
\hline Item & Information need & Planned resolution & Sample required \\
\hline 10 & $\begin{array}{l}\text { Determination of } \mathrm{Na} \\
\text { quantity }\end{array}$ & $\begin{array}{l}\text { Perform lab test; Analysis of } \mathrm{Na} \text { can be obtained by results } \\
\text { from item } \# 5 \text {. }\end{array}$ & None \\
\hline 11 & $\begin{array}{l}\text { Determine the } \\
\text { Chemical and } \\
\text { radionuclide } \\
\text { analyses of heel in } \\
241-A Y-101 .\end{array}$ & $\begin{array}{l}\text { Perform lab test; Analysis of chemical and radionuclides } \\
\text { for compatibility test. }\end{array}$ & $\begin{array}{l}50 \mathrm{ml} \text { of } 241-\mathrm{AY}-101 \\
\text { composite waste. }\end{array}$ \\
\hline 12 & $\begin{array}{l}\text { Desired dilution } \\
\text { ratio and diluent } \\
\text { composition for a } \\
\text { representative } \\
\text { sample of supernate. }\end{array}$ & $\begin{array}{l}\text { Perform lab test: measure minimum dilution ratio which } \\
\text { satisfies all transfer system; measure maximum dilution } \\
\text { ratio where gibbsite will not become a problem. } \\
\text { Determine desired dilution ratio and diluent. }\end{array}$ & $\begin{array}{l}250 \mathrm{ml} 241-\mathrm{AZ}-101 \\
\mathrm{TSC}, 250 \mathrm{ml} \\
241-\mathrm{AZ}-102 \mathrm{TSC} \\
241-\mathrm{AY}-101 \text { sludge, } \\
241-\mathrm{AY}-101 \\
\text { supernate. }\end{array}$ \\
\hline 13 & $\begin{array}{l}\text { Confirm as-retrieved } \\
\text { waste remains below } \\
\text { saturation in major } \\
\text { NA salts during } \\
\text { transfer. }\end{array}$ & $\begin{array}{l}\text { Perform lab test: to confirm that the as retrieved waste } \\
\text { remain below saturation in major Na salts during the } \\
\text { transfer to the staging tanks }\end{array}$ & $\begin{array}{l}250 \mathrm{ml} 241-\mathrm{AZ}-101 \\
\mathrm{TSC}, 250 \mathrm{ml} \\
241-\mathrm{AZ}-102 \mathrm{TSC} \\
241-\mathrm{AY}-101 \text { sludge, } \\
241-\mathrm{AY}-101 \\
\text { supernate. }\end{array}$ \\
\hline 14 & $\begin{array}{l}\text { Confirm as-retrieved } \\
\text { waste remains }<10 \\
\mathrm{cP},<1.5 \mathrm{SpG} \text {, and } \\
<30 \% \text { solids during } \\
\text { transfer. }\end{array}$ & $\begin{array}{l}\text { Perform lab test to determine viscosity, SpG, suspended } \\
\text { solids }\end{array}$ & $\begin{array}{l}\text { None } \\
\text { Use sample from } \\
\text { Item } 13 \text {. }\end{array}$ \\
\hline 15 & $\begin{array}{l}\text { Determine solid } \\
\text { formation, if any. }\end{array}$ & $\begin{array}{l}\text { An extended storage of supernate sub-samples from the } \\
\text { TSC dilution test at dilution ratio up to } 120 \% \text {. }\end{array}$ & $\begin{array}{l}250 \mathrm{ml} 241-\mathrm{AZ}-101 \\
\mathrm{TSC}, 250 \mathrm{ml} \\
241-\mathrm{AZ}-102 \mathrm{TSC} \\
241-\mathrm{AY}-101 \text { sludge, } \\
\text { 241-AY-101 } \\
\text { supernate. }\end{array}$ \\
\hline 16 & $\begin{array}{l}\text { Chemical and } \\
\text { radionuclide } \\
\text { analyses }\end{array}$ & $\begin{array}{l}\text { Measure the analytes in Section } 2.0 \text {, Tables I and } 2 \text { (in } \\
\text { main report) (Envelope B analytes). Determine the bulk } \\
\text { supernate composition }\end{array}$ & $50 \mathrm{mls}$ of blend. \\
\hline 17 & [Na] measurement & Measurement of Na can be obtained from item $\# 16$. & None \\
\hline 18 & $\begin{array}{l}\text { Confirm insoluble } \\
\text { solids fraction limit } \\
\text { will not exceed } 5 \\
\text { volume \%. }\end{array}$ & Measurement of $\%$ solid in the blend. & $50 \mathrm{ml}$ of blend. \\
\hline 19 & $\begin{array}{l}\text { Operating } \\
\text { Specification } \\
\text { requirements }\end{array}$ & $\begin{array}{l}\text { Perform lab test; Analysis of chemical and radionuclides } \\
\text { can be obtained by results from item } \# 16 \text {. }\end{array}$ & None \\
\hline 20 & $\begin{array}{l}\text { Determine the } \\
\text { Chemical and } \\
\text { radionuclide } \\
\text { analyses of heel in } \\
241-\mathrm{AY}-101 .\end{array}$ & $\begin{array}{l}\text { Perform lab test; Analysis of chemical and radionuclides } \\
\text { from 241-AY-101 heel. }\end{array}$ & $\begin{array}{l}50 \mathrm{ml} \text { of } 241-\mathrm{AY}-101 \\
\text { composite waste }\end{array}$ \\
\hline
\end{tabular}


HNF-2799

Revision 0

There are 20 items that have been flagged in Tables 1 and 2 requiring further information. All items will be addressed by a specific process test with specific material from 241-AZ-101/241-AZ-102. There are no other information needs requiring either an analysis of an existing 241-AZ-101/241-AZ-102 sample or the collection of additional sample followed by analysis in order to confirm that tank 241-AZ-101/241-AZ-102 is appropriate for Batch 5 . 
HNF-2799

Revision 0

This page intentionally left blank.

Addendum 5-24 
HNF-2799

Revision 0

\subsection{REFERENCES}

Certa, P. J., W. H. Grams, C. M. McConville, L. W. Shelton and E. J. Slaathaug, 1996, Low-Level Waste Feed Staging Plan, WHC-SD-WM-RPT-224, Rev. 0, Westinghouse Hanford Company, Richland, Washington.

DOE-RL, 1996, TWRS Privatization, Contract Numbers DE-RP06-96RL13308 and 13309, U.S. Department of Energy, Richland, Washington.

Garfield, J. S., 1997, Tank 241-AN-104 Dilution/Dissolution Test Requirements, internal memo to D. L. Herting, 8C451-97-004 (March 27), Numatec Hanford Corporation, Richland, Washington.

Hanlon, B. M., 1998, Waste Tank Summary Report for Month Ending June 30, 1998, HNF-EP-182-123, Lockheed Martin Hanford Company, Richland, Washington.

Herting, D. L, 1998, Test Plan for Tank 241-AZ-101/241-AZ-102 Dilution Studies, HNF-1863, Rev. 0, Numatec Hanford Corporation, Richland, Washington.

Hodgson, K. M., 1995, Tank Characterization Report for Double-Shell Tank 241-AZ-101, WHC-SD-WM-ER-410, Richland, Washington.

Kirkbride, R. A., G. K. Allen, P. J. Certa, A. F. Manuel, R. M. Orme, L. W. Shelton, E. J. Slaathaug, R. S. Wittman, G. T. MacLean, and D. L. Penwell, 1997, Tank Waste Remediation System Operation and Utilization Plan, HNF-SD-WM-SP-012, Rev. 0A, Vol. I and II, Numatec Hanford Corporation, Richland, Washington.

PHMC, 1996, Unclassified Operating Specification for the 241-AN, AP, AW, AY, AZ, and SY Tank Farms, OSD-T-151-00007, Rev. H-18, Fluor Daniel Hanford, Richland, Washington.

PHMC, 1997, Interface Control Document Between DOE and the PHMC, Low-Activity Waste Feed, HNF-SP-1223 (ICD-19), Project Hanford Management Contractor, Richland, Washington.

Ryan, G. W., 1995, Tank Characterization Report for Double-Shell Tank 241-AZ-102, WHC-SD-WM-ER-411, Westinghouse Hanford Company, Richland, Washington. 
HNF-2799

Revision 0

This page intentionally left blank.

Addendum 5-26 
HNF-2799

Revision 0

\section{ADDENDUM 6}

\section{APPLICATION OF}

\section{"CONFIRM TANK T IS AN APPROPRIATE FEED SOURCE FOR LOW-ACTIVITY WASTE FEED BATCH X"}

TO

241-AN-107 / BATCHES 6 AND 7 
HNF-2799

Revision 0

This page intentionally left blank.

Addendum 6-2 
HNF-2799

Revision 0

CONTENTS

1.0 INTRODUCTION $\ldots \ldots \ldots \ldots \ldots \ldots \ldots \ldots \ldots \ldots \ldots \ldots \ldots \ldots$ Addendum $6-5$

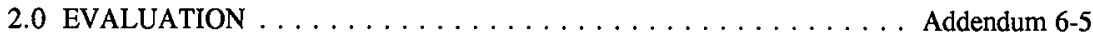

2.1 BASE CASE OPERATING SCENARIO $\ldots \ldots \ldots \ldots \ldots$ Addendum $6-5$

3.0 REFERENCES $\ldots \ldots \ldots \ldots \ldots \ldots \ldots \ldots \ldots \ldots \ldots \ldots \ldots \ldots \ldots$ Addendum 6.13

\section{LIST OF TABLES}

1. Base Case Operating Scenario Evaluation $\ldots \ldots \ldots \ldots \ldots$ Addendum 6-7

2. Information Needs $\ldots \ldots \ldots \ldots \ldots \ldots \ldots \ldots \ldots \ldots$ Addendum 6 -11 
HNF-2799

Revision 0

\section{LIST OF TERMS}

DOE U.S. Department of Energy

ICD Interface Control Document

LAW Low-Activity Waste

M Molar (gmoles/liter)

PHMC Project Hanford Management Contract(or)

PMBS Project Master Baseline Schedule

PSDQO Problem-Specific Data Quality Objectives

RL U.S. Department of Energy-Richland Operations

SC Supernate Composite

TANK T Refers to the contents from one tank, multiple tanks, or portions of one or more tanks that will be used to prepare a feed batch

TOC Total Organic Carbon

TWRS Tank Waste Remediation System

TWRSO\&UP Tank Waste Remediation System Operation and Utilization Plan 
HNF-2799

Revision 0

\section{ADDENDUM 6}

\section{APPLICATION OF "CONFIRM TANK T IS AN APPROPRIATE FEED SOURCE FOR LOW-ACTIVITY WASTE FEED BATCH X" TO 241-AN-107/BATCHES 6 AND 7}

\subsection{INTRODUCTION}

This addendum applies Revision 1 of "Confirm Tank $T$ is an Appropriate Feed Source for Low-Activity Waste Feed Batch X" (Certa and Jo 1998) problem-specific data quality objectives (PSDQO) to tank 241-AN-107 / Batches 6 and 7.

This application of the DQO applies to transfers of the waste in the tank 241-AN-107 supernate to 241-AP-102 and 241-AP-104 without mixing.

\subsection{EVALUATION}

\subsection{BASE CASE OPERATING SCENARIO}

Translate the operating scenario into a series of process steps.

The TWRSO\&UP (Kirkbride et al. 1997) recommended that process control issues be taken into account. This base case operating scenario was developed based on consideration of process control issues and is currently being evaluated and incorporated into the project master baseline schedule and corresponding logic diagrams. The steps that directly affect the composition of Batches 6 and 7 are listed below:

- Empty, flush, and empty 241-AP-102 and 241-AP-104 (the feed staging tanks) leaving a dilute, $0.1 \mathrm{ML}(10$-in.) heel behind in each tank.

- Decant the supernate in 241-AN-107; transfer half of the supernate to 241-AP-102 and the remainder to 241-AP-104, leaving a 10-in. heel above the salt slurry. During these transfers diluent will be added to the waste at the pump inlet.

The heel remaining in 241-AP-102 and 241-AP-104 can be neglected for the purposes of this PSDQO; how clean the staging tank needs to be is an operational issue, not a "Confirm Tank T..." issue. 
HNF-2799

Revision 0

Define the waste that applies to each element in the decision rule.

Element 1, Dilution Ratio and Diluent Composition: this applies to a supernate composite (SC) from 241-AN-107 over the temperature range of 25 to $65^{\circ} \mathrm{C}$.

Element 2, Transfer Requirements applies to supernate composite from 241-AN-107 after addition of the proper amount of diluent over the temperature range of 25 to $65^{\circ} \mathrm{C}$.

Element 3, Dissolution Requirements: NA

Element 4, Envelope Requirements: there is one unique composition for batch 6 and for batch 7; the composition and physical properties are that of a SC of the waste currently in 241-AN-107 after addition of the proper amount of diluent over the temperature range of 25 to $65^{\circ} \mathrm{C}$. The dilute heel in 241-AP-102 and 241-AP-104 can be neglected for the purposes of this PSDQO (all current data strongly indicate that 241-AP-102 and 241-AP-104 heel will not interfere with staging the compositionally correct feed); how clean the tank needs to be is an operational issue, not a "Confirm Tank T..." issue.

Element 5, Miscellaneous Inputs: these inputs apply to the SC of 241-AN-107 or to changes in the operating scenario that may be imposed in the future.

Evaluate existing data and determine information needs.

Table 1 contains the evaluation of the base case operating scenario for all the elements of the decision rule found in Section 6 of the DQO for Confirm Tank T. The table lists each element of the decision rule taken from Section 4.0 of the DQO. For each element, the requirements specific to 241-AN-107 / Batches 6 and 7 are listed. Each requirement is evaluated against existing data and remaining information needs are identified. The information needs are developed more fully in Table 2 . 
Table 1. Base Case Operating Scenario Evaluation. (4 Sheets)

\begin{tabular}{|c|c|c|c|}
\hline Elements $^{\mathrm{a}}$ & Requirements $^{b}$ & Discussion/evaluation & Information needs \\
\hline $\begin{array}{l}\text { Element 2, } \\
\text { Transfer } \\
\text { Requirements are } \\
\text { Satisfied }\end{array}$ & $\begin{array}{l}\text { Confirm that the as-retrieved waste } \\
\text { (including dilution water or caustic) } \\
\text { remain at or below viscosity of } 10 \mathrm{cP} \text {, at } \\
\text { or below a } 1.5 \mathrm{SpG} \text {, and at or below } 30 \\
\text { percent solids by volume during the } \\
\text { transfer to the staging tank. }\end{array}$ & $\begin{array}{l}\text { As applied to supernate composite with proper amount of diluent added: } \\
\text { A process test will be performed. }\end{array}$ & $\begin{array}{l}\text { See requirement (See } \\
\text { Table 2, Item } \# 3 \text { ). }\end{array}$ \\
\hline $\begin{array}{l}\text { Element 3, } \\
\text { Dissolution } \\
\text { Requirements }\end{array}$ & NA & NA & NA \\
\hline $\begin{array}{l}\text { Element } 4 \text { - Part 1: } \\
\text { Envelope } \\
\text { Requirements }\end{array}$ & $\begin{array}{l}\text { Concentration limits for the chemical and } \\
\text { radionuclide content of the feed (DOE-RL } \\
\text { 1996, Section C.6). } \\
\text { See Section } 2.0 \text {, Tables } 1 \text { and } 2 \text { (in main } \\
\text { report) for the limits. }\end{array}$ & Only Envelope $C$ limits apply to Batches 6 and 7. & $\begin{array}{l}\text { Chemical and } \\
\text { radionuclide analyses } \\
\text { from tests (See Table } \\
2 \text {, Item \# 5). }\end{array}$ \\
\hline
\end{tabular}


Table 1. Base Case Operating Scenario Evaluation. (4 Sheets)

\begin{tabular}{|c|c|c|c|}
\hline Elements ${ }^{\mathrm{a}}$ & Requirements $^{b}$ & Discussion/evaluation & Information needs \\
\hline $\begin{array}{l}\text { Element } 4 \text { - Part 1: } \\
\text { Envelope } \\
\text { Requirements } \\
\text { (continued) }\end{array}$ & $\begin{array}{l}\text { Insoluble solids fraction limit will not } \\
\text { exceed } 5 \text { volume \% (DOE-RL 1996, } \\
\text { Section C.6). }\end{array}$ & $\begin{array}{l}\text { The only solids that should end up in the feed batch are those solids that } \\
\text { are inadvertently entrained during the decant transfers. This is an } \\
\text { operational issue, not a "Confirm Tank T..." issue. } \\
\text { Compliance with insoluble fraction will be resolved by case during } \\
\text { operations. }\end{array}$ & $\begin{array}{l}\text { No further } \\
\text { information is } \\
\text { needed. }\end{array}$ \\
\hline $\begin{array}{l}\text { These limits apply } \\
\text { to the feed actually } \\
\text { delivered to the } \\
\text { private contractors. }\end{array}$ & $\begin{array}{l}\text { Operating Specifications from } \\
\text { OSD-T-151-00007 (DOE-RL 1996, } \\
\text { Section C. } 6 \text { invokes the OSD by } \\
\text { reference). } \\
\text { See Section } 2.0 \text {, Table } 3 \text { (in main report). }\end{array}$ & $\begin{array}{l}\text { The contract does not explicitly state which specifications from the OSD } \\
\text { apply to the waste. The PHMC assumes that the Tank Composition } \\
\text { (7.2.1) and Heat Generation Rate (7.2.8) limits apply to the waste. } \\
\text { These limits are shown in Section } 2.0 \text {, Table } 3 \text { (in main report). } \\
\text { The TWRSO\&UP (Kirkbride et al. 1997, Section } 3.1 .1 .6 \text { ) compared } \\
\text { the point estimates of the composition of the waste as staged in } 241 \text {-AP- } \\
102 \text { and } 241 \text {-AP-104 with the Tank Composition (Tank Corrosion) } \\
\text { specifications. All limits were satisfied for Batches } 6 \text { \& } 7 \text {. Uncertainty } \\
\text { is not an issue since the [OH], [ } \mathrm{NO}_{2} \text { ] and [NO } \mathrm{N}_{3} \text { ] in the staging tanks can } \\
\text { be adjusted if needed before the feed qualification samples are taken. } \\
\text { The TWRSO\&UP (Section } 3.1 .1 .6 \text { ) also evaluated the heat generation } \\
\text { rate rule and found that all limits were satisfied for Batches } 6 \text { \& } 7 \text {, } \\
\text { decayed to the estimated time of delivery. The estimated heat } \\
\text { generation rate for Batches } 6 \& 7 \text { are } 4,900 \text { and } 8,300 \text { BTU/hr, } \\
\text { respectively. This is well within the maximum limit of } 70,000 \text { BTU/hr. } \\
\text { The tank characterization report estimated the total heat load in } \\
241 \text {-AN-107 (Jo } 1996 \text { ) to be } 8,060 \text { W (27,500 BTU/hr). This estimate } \\
\text { is also well below the maximum limit. This estimate is conservative } \\
\text { since it does not take into account the additional decay that will take } \\
\text { place before delivery of the feed Batch. } \\
\text { Conformance with OSD factors achieved. }\end{array}$ & $\begin{array}{l}\text { Estimated } \\
\text { composition of the } \\
\text { staged feed (See } \\
\text { Table } 2, \text { Item } \# 6 \text { ). }\end{array}$ \\
\hline
\end{tabular}


HNF-2799

Revision 0

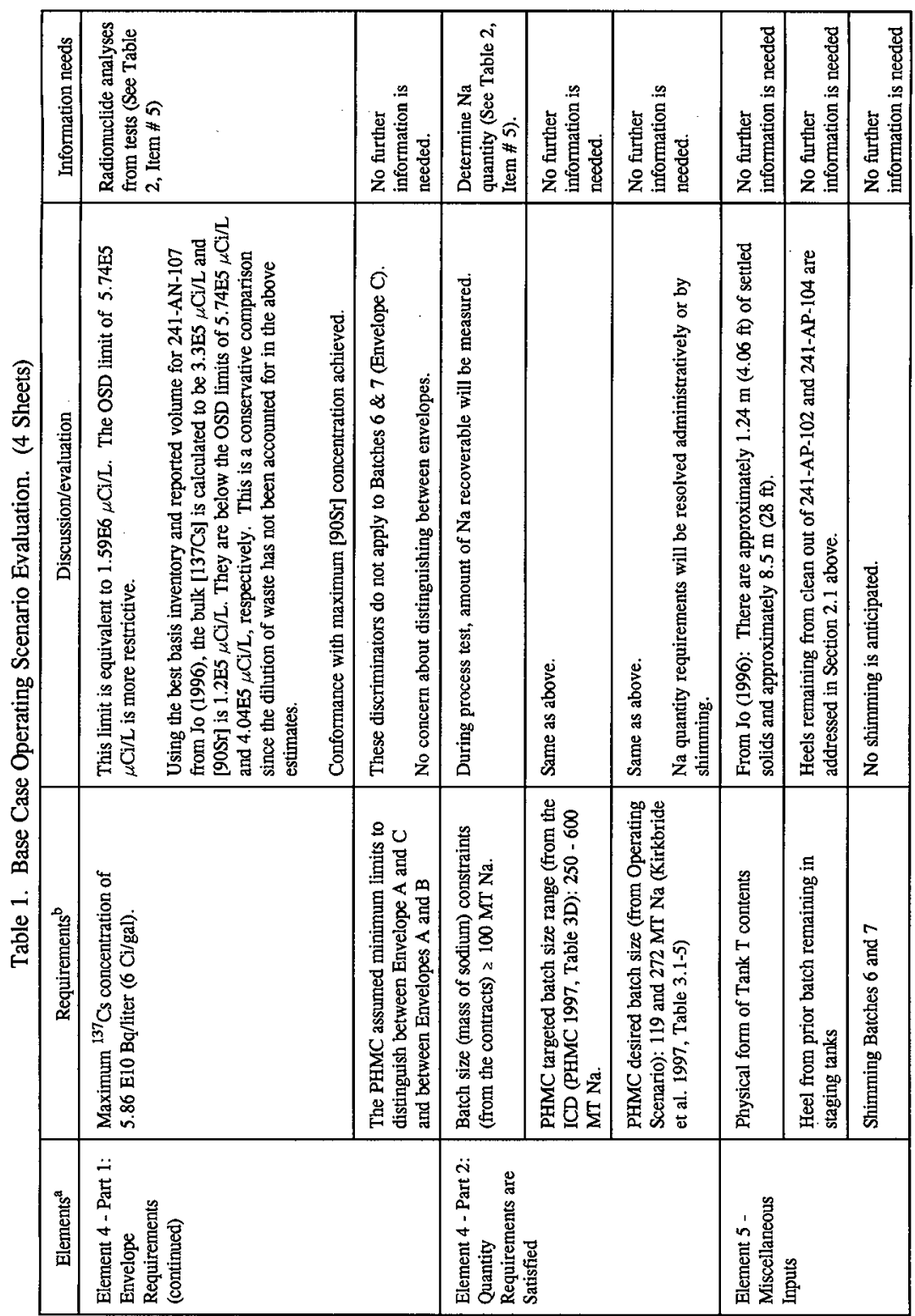


Table 1. Base Case Operating Scenario Evaluation. (4 Sheets)

\begin{tabular}{|l|l|l|l|}
\hline \multicolumn{1}{|c|}{ Elements } & \multicolumn{1}{|c|}{ Requirements $^{\mathrm{b}}$} & \multicolumn{1}{c|}{ Discussion/evaluation } & \multicolumn{1}{c|}{ Information needs } \\
\hline $\begin{array}{l}\text { Element } 5 \text { - } \\
\text { Miscellaneous } \\
\text { Inputs (continued) }\end{array}$ & RL direction & $\begin{array}{l}\text { No changes to applicable M\&I ICD requirements have been made to } \\
\text { date. }\end{array}$ & $\begin{array}{l}\text { No further } \\
\text { information is needed }\end{array}$ \\
\cline { 2 - 5 } & Decant level & During a sampling event determine the solid liquid interface. & $\begin{array}{l}\text { Determine decant } \\
\text { level (See Table 2, } \\
\text { Item \# 7). }\end{array}$ \\
\hline
\end{tabular}

${ }^{a}$ Elements are taken from the Decision Rule statement in Section 4.0 of PSDQO-01.

${ }^{\mathrm{b}}$ Requirements are taken from Sections $4.1,4.2,4.3,4.4$, and 4.5 of PSDQO-01. 
Table 2 was developed jointly by TWRS Characterization and Tank Waste Retrieval. It is intended to show what information is still needed, what can be obtained by calculations with existing data, what requires new (or existing) samples, analysis and/or process testing. Where samples are required, the amount and "representativeness" of the sample will be stated. Where analysis is needed, the specific analytes and QA requirements will be stated. If process testing is needed, the amount of sample and goals of the process test will be stated.

Appropriate level of end description of QA requirements will be covered in the specific work plan for these limited process tests.

Table 2. Information Needs.

\begin{tabular}{|l|l|l|l|}
\hline Item & \multicolumn{1}{|c|}{ Information need } & \multicolumn{1}{|c|}{ Planned resolution } & \multicolumn{1}{|c|}{$\begin{array}{l}\text { Sample } \\
\text { required }\end{array}$} \\
\hline 1 & $\begin{array}{l}\text { Desired dilution ratio and } \\
\text { diluent composition for a } \\
\text { representative sample of } \\
\text { supernate. }\end{array}$ & Process testing will be performed. & $\begin{array}{l}360 \mathrm{~mL} \text { of } \\
\text { supernate } \\
\text { composite. }\end{array}$ \\
\hline 2 & $\begin{array}{l}\text { Confirm as-retrieved waste } \\
\text { remains below satn in } \\
\text { major Na salts during } \\
\text { transfer. }\end{array}$ & $\begin{array}{l}\text { Performing process test: measure } \\
\% \text { solids vs. temp for supernate at } 25, \\
45, \text { and } 65^{\circ} \text { C under 3 conditions: } \\
\text { undiluted, 10\% diluted and 20\% } \\
\text { diluted. }\end{array}$ & $\begin{array}{l}\text { None. Use } \\
\text { samples from } \\
\text { Item \#1. }\end{array}$ \\
\hline 3 & $\begin{array}{l}\text { Confirm as-retrieved waste } \\
\text { remains }<10 \text { cP, }<1.5 \\
\text { SpG, and }<30 \% \text { solids } \\
\text { during transfer. }\end{array}$ & $\begin{array}{l}\text { SpG, viscosity and \%Solids will be } \\
\text { measured during the process test.. }\end{array}$ & $\begin{array}{l}\text { None. Use } \\
\text { samples from } \\
\text { Item \#1. }\end{array}$ \\
\hline 4 & $\begin{array}{l}\text { Precipitation at 0, 40, 80, } \\
\text { and } 120 \% \text { dilutions }\end{array}$ & $\begin{array}{l}\text { Process testing will be performed at } \\
\text { these dilutions. }\end{array}$ & $\begin{array}{l}\text { None. Use } \\
\text { samples from } \\
\text { Item \#1. }\end{array}$ \\
\hline 5 & $\begin{array}{l}\text { Chemical and radionuclide } \\
\text { analyses from process test }\end{array}$ & A process test will be performed. & $\begin{array}{l}\text { None. Use } \\
\text { samples from } \\
\text { Item \#1. }\end{array}$ \\
\hline 6 & $\begin{array}{l}\text { Estimate composition of } \\
\text { staged feed. }\end{array}$ & $\begin{array}{l}\text { Can be calculated from existing data } \\
\text { after item \#1 is resolved. }\end{array}$ & $\begin{array}{l}\text { None. Use } \\
\text { samples from } \\
\text { Item \#1. }\end{array}$ \\
\hline 7 & Determine decant level. & Determine Wt. \% solid for each level. & $\begin{array}{l}50 \text { mls from } \\
\text { each sample } \\
\text { level. }\end{array}$ \\
\hline
\end{tabular}


HNF-2799

Revision 0

There are seven items that have been flagged in Table 1 requiring further information. All items are being addressed by a specific process test with specific material from 241-AN-107. There are no other information needs requiring either an analysis of an existing 241-AN-107 sample or the collection of additional sample followed by analysis in order to confirm that tank 241-AN-107 is appropriate for Batches 6 and 7. 
HNF-2799

Revision 0

\subsection{REFERENCES}

Certa, P. J., J. Jo, 1998, Data Quality Objectives for TWRS Privatization Phase: 1 confirm Tank T is an Appropriate Feed Source for Low-Activity Waste Feed Batch X, HNF-1796, Rev. 1, Numatec Hanford Corporation, Richland, Washington.

DOE-RL, 1996, TWRS Privatization, Contract Numbers DE-RP06-96RL13308 and 13309, U.S. Department of Energy, Richland, Washington.

Jo, J., J. D. Franklin, D. J. Morris, and L. C. Amato, 1996, Tank Characterization Report for Double-Shell Tank 241-AN-107, WHC-SD-WM-ER-600, Rev. 0, Westinghouse Hanford Company, Richland, Washington.

Kirkbride, R. A., G. K. Allen, P. J. Certa, A. F. Manuel, R. M. Orme, L. W. Shelton, E. J. Slaathaug, R. S. Wittman, G. T. MacLean and D. L. Penwell, 1997, Tank Waste Remediation System Operation and Utilization Plan, HNF-SD-WM-SP-012, Rev. OA, Vol. I and II, Numatec Hanford Corporation, Richland, Washington.

PHMC, 1996, Unclassified Operating Specification for the 241-AN, $A P, A W, A Y, A Z$, and $S Y$ Tank Farms, OSD-T-151-00007, Rev. H-18, Fluor Daniel Hanford, Richland, Washington.

PHMC, 1997, Interface Control Document Between DOE and the PHMC, Low-Activity Waste Feed, HNF-SP-1223 (ICD-19), Project Hanford Management Contractor, Richland, Washington. 
HNF-2799

Revision 0

This page intentionally left blank.

Addendum 6-14 


\section{ADDENDUM 7}

\section{APPLICATION OF}

\section{"CONFIRM TANK T IS AN APPROPRIATE FEED SOURCE FOR LOW-ACTIVITY WASTE FEED BATCH $X "$}

\section{TO}

241-AN-102 / BATCH 8 
HNF-2799

Revision 0

This page intentionally left blank.

Addendum 7-2 
HNF-2799

Revision 0

CONTENTS

1.0 INTRODUCTION $\ldots \ldots \ldots \ldots \ldots \ldots \ldots \ldots \ldots \ldots \ldots \ldots \ldots \ldots \ldots \ldots$ Addendum $7-5$

2.0 EVALUATION $\ldots \ldots \ldots \ldots \ldots \ldots \ldots \ldots \ldots \ldots \ldots \ldots \ldots \ldots \ldots \ldots$ Addendum $7-5$

2.1 BASE CASE OPERATING SCENARIO $\ldots \ldots \ldots \ldots$ Addendum $7-5$

3.0 REFERENCES $\ldots \ldots \ldots \ldots \ldots \ldots \ldots \ldots \ldots \ldots \ldots \ldots \ldots \ldots \ldots \ldots$ Addendum $7-13$

\section{LIST OF TABLES}

1. Base Case Operating Scenario Evaluation. $\ldots \ldots \ldots \ldots \ldots \ldots$ Addendum $7-7$

2. Information Needs $\ldots \ldots \ldots \ldots \ldots \ldots \ldots \ldots$ Addendum $7-11$ 
HNF-2799

Revision 0

\section{LIST OF TERMS}

DOE

U.S. Department of Energy

ICD

Interface Control Document

LAW

Low-Activity Waste

$\mathbf{M}$

Molar (gmoles/liter)

PHMC Project Hanford Management Contract(or)

PMBS

Project Master Baseline Schedule

PSDQO

Problem-Specific Data Quality Objectives

RL

U.S. Department of Energy-Richland Operations

SC

Supernate Composite

TANK T

Refers to the contents from one tank, multiple tanks, or portions of one or more tanks that will be used to prepare a feed batch

TOC

Total Organic Carbon

TWRS

Tank Waste Remediation System

TWRSO\&UP Tank Waste Remediation System Operation and Utilization Plan 
HNF-2799

Revision 0

ADDENDUM 7

APPLICATION OF "CONFIRM TANK T IS AN APPROPRIATE FEED SOURCE FOR LOW-ACTIVITY WASTE FEED BATCH X" TO 241-AN-102 / BATCH 8

\subsection{INTRODUCTION}

This addendum applies Revision 1 of "Confirm Tank $T$ is an Appropriate Feed Source for Low-Activity Waste Feed Batch X" (Certa and Jo 1998) problem-specific data quality objectives (PSDQO) to tank 241-AN-102 / Batch 8.

This application of the DQO applies to transfers of the waste in the tank 241-AN-102 supernate to 241-AP-102 and 241-AP-104 without mixing.

\subsection{EVALUATION}

\subsection{BASE CASE OPERATING SCENARIO}

Translate the operating scenario into a series of process steps.

The TWRSO\&UP (Kirkbride et al. 1997) recommended that process control issues be taken into account. This base case operating scenario was developed based on consideration of process control issues and is currently being evaluated and incorporated into the project master baseline schedule and corresponding logic diagrams. The steps that directly affect the composition of Batch 8 are listed below:

- Empty 241-AP-102 and 241-AP-104 (the feed staging tanks) leaving a dilute, 0.1 ML (10-in.) heel behind in each tank.

- Decant the supernate in 241-AN-102; transfer half of the supernate to 241-AP-102 and the remainder to 241-AP-104, leaving a 10-in. heel above the salt slurry. During these transfers diluent will be added to the waste at the pump inlet.

The heel remaining in 241-AP-102 and -104 can be neglected for the purposes of this PSDQO; how clean the staging tank needs to be is an operational issue, not a "Confirm Tank T..." issue. Furthermore, diluted Batch 8 waste will be within Envelope $\mathrm{C}$ specifications, and mixing wastes from different tanks/batches within the defined specifications should not have an adverse effect on operations. 
HNF-2799

Revision 0

Define the waste that applies to each element in the decision rule.

Element 1, Dilution Ratio and Diluent Composition: this applies to a supernate composite (SC) from 241-AN-102 over the temperature range of 25 to $65{ }^{\circ} \mathrm{C}$.

Element 2, Transfer Requirements applies to supernate composite from 241-AN-102 after addition of the proper amount of diluent over the temperature range of 25 to $65^{\circ} \mathrm{C}$.

Element 3, Dissolution Requirements: NA

Element 4, Envelope Requirements: there is one unique composition for Batch 8 ; the composition and physical properties are that of a SC of the waste currently in $241-\mathrm{AN}-102$ after addition of the proper amount of diluent over the temperature range of 25 to $65^{\circ} \mathrm{C}$. The dilute heel in 241-AP-102 and 241-AP-104 can be neglected for the purposes of this PSDQO (all current data strongly indicate that 241-AP-102 and 241-AP-104 heel will not interfere with staging the compositionally correct feed); how clean the tank needs to be is an operational issue, not a "Confirm Tank T..." issue.

Element 5, Miscellaneous Inputs: these inputs apply to the SC of 241-AN-102 or to changes in the operating scenario that may be imposed in the future.

Evaluate existing data and determine information needs.

Table 1 contains the evaluation of the base case operating scenario for all the elements of the decision rule found in Section 6 of the DQO for Confirm Tank T. The table lists each element of the decision rule taken from Section 4.0 of the DQO. For each element, the requirements specific to 241-AN-102 / Batch 8 are listed. Each requirement is evaluated against existing data and remaining information needs are identified. The information needs are developed more fully in Table 2. 
Table 1. Base Case Operating Scenario Evaluation. (4 Sheets)

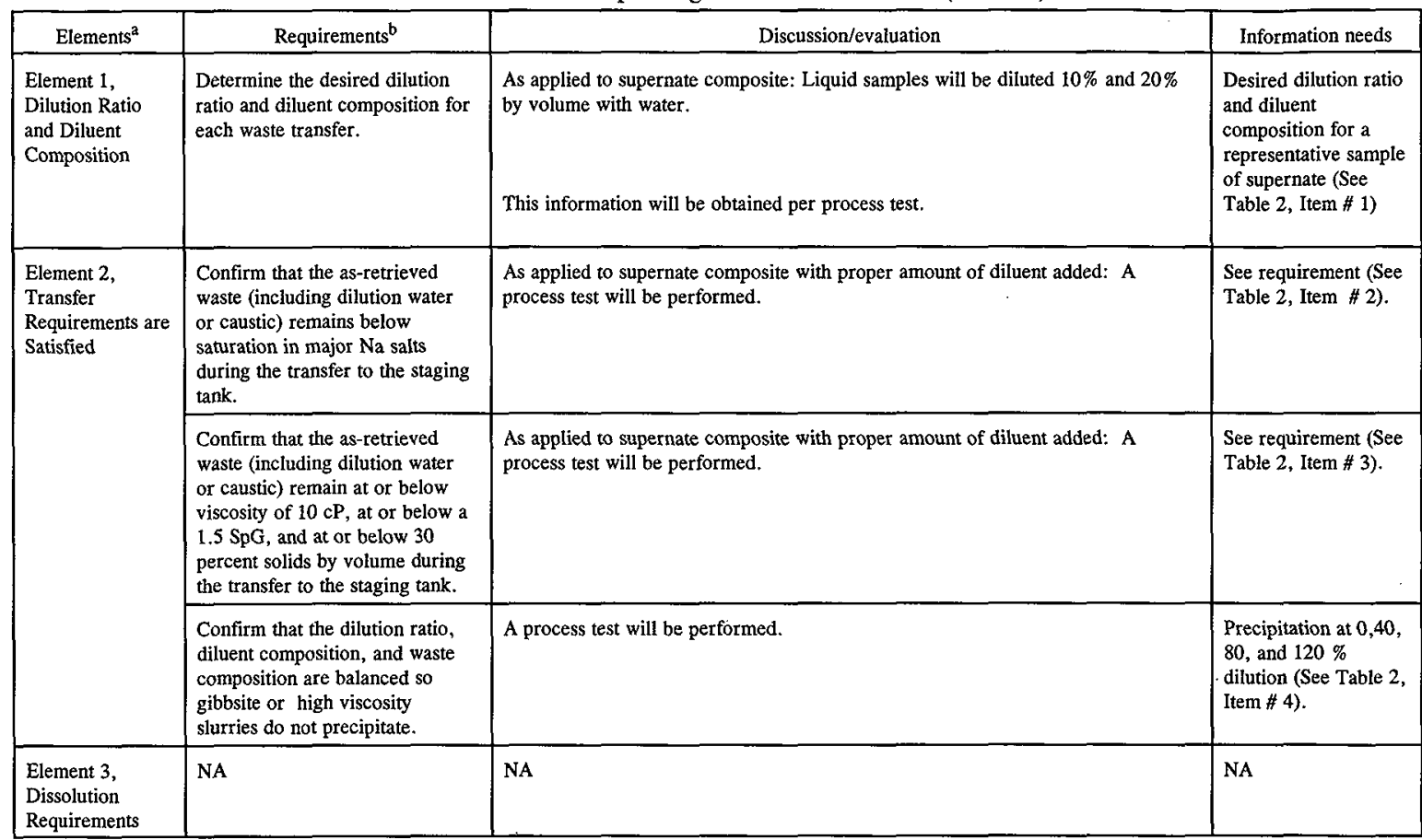


Table 1. Base Case Operating Scenario Evaluation. (4 Sheets)

\begin{tabular}{|c|c|c|c|}
\hline Elements $^{\mathrm{a}}$ & Requirements $^{\mathrm{b}}$ & Discussion/evaluation & Information needs \\
\hline \multirow[t]{2}{*}{$\begin{array}{l}\text { Element } 4 \text { - Part } \\
\text { 1: Envelope } \\
\text { Requirements }\end{array}$} & $\begin{array}{l}\text { Concentration limits for the } \\
\text { chemical and radionuclide } \\
\text { content of the feed (DOE-RL } \\
\text { 1996, Section C.6). } \\
\text { See Section } 2.0 \text {, Tables I and } 2 \\
\text { (in main report) for the limits. }\end{array}$ & Only Envelope C limits apply to Batch 8. & $\begin{array}{l}\text { Chemical and } \\
\text { radionuclide analyses } \\
\text { from tests (See Table } \\
2 \text {, Item } \# 5 \text { ). }\end{array}$ \\
\hline & $\begin{array}{l}\text { Concentration limit for the } \\
\text { sodium concentration of the feed: } \\
3 \mathrm{M} \leq[\mathrm{Na}] \leq 14 \mathrm{M} \text { (DOE-RL } \\
\text { 1996, Section C.6). }\end{array}$ & During process test $[\mathrm{Na}]$ will be measured. & $\begin{array}{l}\text { Chemical and } \\
\text { radionuclide analyses } \\
\text { from tests (See Table } \\
2 \text {, Item \# 5). }\end{array}$ \\
\hline $\begin{array}{l}\text { These limits } \\
\text { apply to the feed } \\
\text { actually } \\
\text { delivered to the } \\
\text { private } \\
\text { contractors. }\end{array}$ & $\begin{array}{l}\text { Insoluble solids fraction limit will } \\
\text { not exceed } 5 \text { volume \% (DOE- } \\
\text { RL 1996, Section C.6). }\end{array}$ & $\begin{array}{l}\text { The only solids that should end up in the feed batch are those solids that are } \\
\text { inadvertently entrained during the decant transfers. This is an operational issue, } \\
\text { not a "Confirm Tank T..." issue. } \\
\text { Compliance with insoluble fraction will be resolved by case during operations. }\end{array}$ & $\begin{array}{l}\text { No further } \\
\text { information is } \\
\text { needed. }\end{array}$ \\
\hline
\end{tabular}


Table 1. Base Case Operating Scenario Evaluation. (4 Sheets)

\begin{tabular}{|c|c|c|c|}
\hline Elements $^{\mathrm{a}}$ & Requirements ${ }^{b}$ & Discussion/evaluation & Information needs \\
\hline & $\begin{array}{l}\text { Maximum }{ }^{137} \mathrm{Cs} \text { concentration of } \\
5.86 \mathrm{E} 10 \mathrm{~Bq} / \text { liter }(6 \mathrm{Ci} / \mathrm{gal}) \text {. }\end{array}$ & $\begin{array}{l}\text { This limit is equivalent to } 1.59 \mathrm{E} 6 \mu \mathrm{Ci} / \mathrm{L} \text {. The } \mathrm{OSD} \text { limit of } 5.74 \mathrm{E} 5 \mu \mathrm{Ci} / \mathrm{L} \text { is } \\
\text { more restrictive. } \\
\text { Using the best basis inventory and reported volume for } 241-\mathrm{AN}-102 \text { from Jo } \\
(1996) \text {, the bulk [137Cs] is calculated to be } 3.8 \mathrm{E} 5 \mu \mathrm{Ci} / \mathrm{L} \text { and }[90 \mathrm{Sr}] \text { is } 7.4 \mathrm{E} 4 \\
\mu \mathrm{Ci} / \mathrm{L} \text {. They are below the OSD limits of } 5.74 \mathrm{E} 5 \mu \mathrm{Ci} / \mathrm{L} \text { and } 4.04 \mathrm{ES} \mu \mathrm{Ci} / \mathrm{L} \text {, } \\
\text { respectively. This is a conservative comparison since the dilution of waste has not } \\
\text { been accounted for in the above estimates. } \\
\text { Conformance with maximum [90Sr] concentration achieved. }\end{array}$ & $\begin{array}{l}\text { Radionuclide analyses } \\
\text { from tests (See Table } \\
\text { 2, Item \# 5) }\end{array}$ \\
\hline
\end{tabular}


Table 1. Base Case Operating Scenario Evaluation. (4 Sheets)

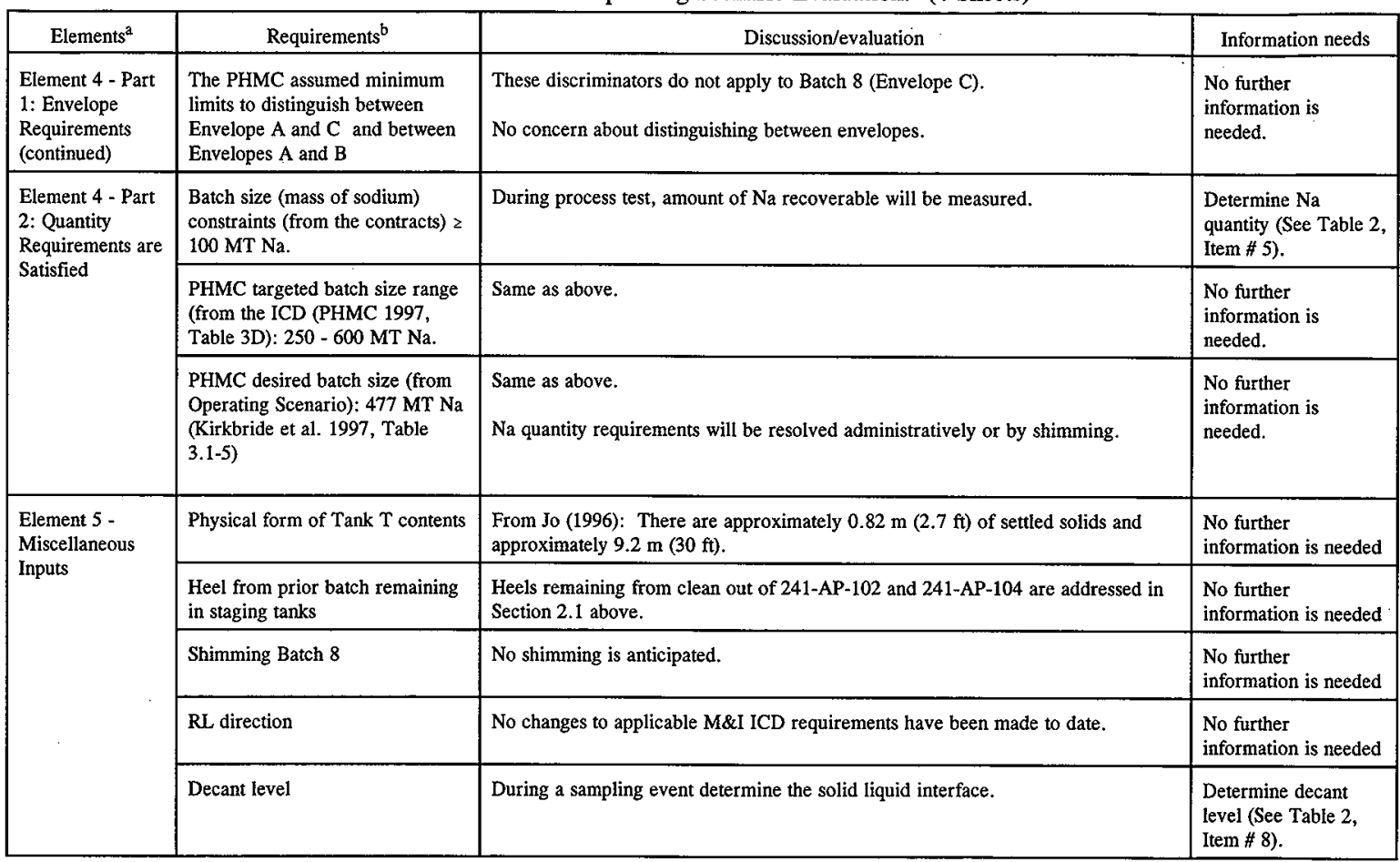

aElements are taken from the Decision Rule statement in Section 4.0 of PSDQO-01.

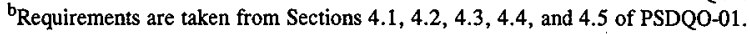


Table 2 was developed jointly by TWRS Characterization and Tank Waste Retrieval. It is intended to show what information is still needed, what can be obtained by calculations with existing data, what requires new (or existing) samples, analysis and/or process testing. Where samples are required, the amount and "representativeness" of the sample will be stated. Where analysis is needed, the specific analytes and QA requirements will be stated. If process testing is needed, the amount of sample and goals of the process test will be stated. Appropriate level of end description of QA requirements will be covered in the specific work plan for these limited process tests.

Table 2. Information Needs.

\begin{tabular}{|l|l|l|l|}
\hline Item & \multicolumn{1}{|c|}{ Information need } & \multicolumn{1}{|c|}{ Planned resolution } & \multicolumn{1}{|c|}{$\begin{array}{l}\text { Sample } \\
\text { required }\end{array}$} \\
\hline 1 & $\begin{array}{l}\text { Desired dilution ratio } \\
\text { and diluent composition } \\
\text { for a representative } \\
\text { sample of supernate. }\end{array}$ & Process testing will be performed. & $\begin{array}{l}350 \mathrm{~mL} \text { of } \\
\text { supernate } \\
\text { composite. }\end{array}$ \\
\hline 2 & $\begin{array}{l}\text { Confirm as-retrieved } \\
\text { waste remains below satn } \\
\text { in major Na salts during } \\
\text { transfer. }\end{array}$ & $\begin{array}{l}\text { Performing process test: measure } \\
\text { \%solids vs, temp for supernate at } 25,45 \\
\text { and } 65^{\circ} \mathrm{C} \text { under 3 conditions: } \\
\text { undiluted, 10\% diluted and 20\% diluted. }\end{array}$ & $\begin{array}{l}\text { None. Use } \\
\text { samples from } \\
\text { Item \#1. }\end{array}$ \\
\hline 3 & $\begin{array}{l}\text { Confirm as-retrieved } \\
\text { waste remains }<10 \mathrm{cP}, \\
<1.5 \text { SpG, and <30\% } \\
\text { solids during transfer. }\end{array}$ & $\begin{array}{l}\text { SpG, viscosity and \%Solids will be } \\
\text { measured during the process test.. }\end{array}$ & $\begin{array}{l}\text { None. Use } \\
\text { samples from } \\
\text { Item \#1. }\end{array}$ \\
\hline 4 & $\begin{array}{l}\text { Precipitation at } 0,40, \\
80, \text { and } 120 \% \text { dilutions }\end{array}$ & $\begin{array}{l}\text { Process testing will be performed at } \\
\text { these dilutions. }\end{array}$ & $\begin{array}{l}\text { None. Use } \\
\text { samples from } \\
\text { Item \#1. }\end{array}$ \\
\hline 5 & $\begin{array}{l}\text { Chemical and } \\
\text { radionuclide analyses } \\
\text { from process test }\end{array}$ & A process test will be performed. & $\begin{array}{l}\text { None. Use } \\
\text { samples from } \\
\text { Item \#1. }\end{array}$ \\
\hline 6 & $\begin{array}{l}\text { Estimate composition of } \\
\text { staged feed. }\end{array}$ & $\begin{array}{l}\text { Can be calculated from existing data } \\
\text { after item \#1 is resolved. }\end{array}$ & $\begin{array}{l}\text { None. Use } \\
\text { samples from } \\
\text { Item \#1. }\end{array}$ \\
\hline 7 & $\begin{array}{l}\text { Determine amount of } \\
\text { NaOH addition. }\end{array}$ & A process test will be performed. & $\begin{array}{l}50 \text { mls } \\
\text { supernate } \\
\text { composite }\end{array}$ \\
\hline 8 & $\begin{array}{l}\text { Determine decant level. } \\
\text { fach sample } \\
\text { level. }\end{array}$ \\
\hline
\end{tabular}


HNF-2799

Revision 0

There are eight items that have been flagged in Table 1 requiring further information. All items are being addressed by a specific process test with specific material from 241-AN-102. There are no other information needs requiring either an analysis of an existing 241-AN-102 sample or the collection of additional sample followed by analysis in order to confirm that tank 241-AN-102 is appropriate for Batch 8. 
HNF-2799

Revision 0

\subsection{REFERENCES}

Certa, P. J., J. Jo, 1998, Data Quality Objectives for TWRS Privatization Phase: 1 confirm Tank $T$ is an Appropriate Feed Source for Low-Activity Waste Feed Batch X, HNF-1796, Rev 1, Numatec Hanford Corporation, Richland, Washington.

DOE-RL, 1996, TWRS Privatization, Contract Numbers DE-RP06-96RL13308 and 13309, U.S. Department of Energy, Richland, Washington.

Jo, J., J. G. Douglas, L. C. Amato, J. D. Franklin, and T. T. Tran, 1996, Tank Characterization Report for Double-Shell Tank 241-AN-102, WHC-SD-WM-ER-545, Rev 0, Westinghouse Hanford Company, Richland, Washington.

Kirkbride, R. A., G. K. Allen, P. J. Certa, A. F. Manuel, R. M. Orme, L. W. Shelton, E. J. Slaathaug, R. S. Wittman, G. T. MacLean and D. L. Penwell, 1997, Tank Waste Remediation System Operation and Utilization Plan, HNF-SD-WM-SP-012, Rev 0A, Vol I and II, Numatec Hanford Corporation, Richland, Washington.

PHMC, 1996, Unclassified Operating Specification for the 241-AN, AP, AW, AY, AZ, and SY Tank Farms, OSD-T-151-00007, Rev H-18, Fluor Daniel Hanford, Richland, Washington.

PHMC, 1997, Interface Control Document Between DOE and the PHMC, Low Activity Waste Feed, HNF-SP-1223 (ICD-19), Project Hanford Management Contractor, Richland, Washington. 
HNF-2799

Revision 0

This page intentionally left blank. 


\section{ADDENDUM 8}

\section{APPLICATION OF}

\section{"CONFIRM TANK T IS AN APPROPRIATE FEED SOURCE FOR LOW-ACTIVITY WASTE FEED BATCH 10"}

TO

241-SY-101 / BATCH 10 
HNF-2799

Revision 0

This page intentionally left blank. 
HNF-2799

Revision 0

\section{CONTENTS}

1.0 INTRODUCTION $\ldots \ldots \ldots \ldots \ldots \ldots \ldots \ldots \ldots \ldots \ldots \ldots \ldots \ldots \ldots$ Addendum $8-5$.

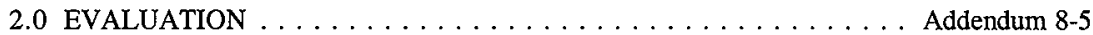

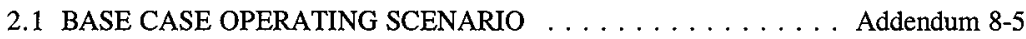

2.2 ALTERNATIVE CASE 1 OPERATING SCENARIO $\ldots \ldots \ldots$. . . Addendum 8-7

2.3 ALTERNATIVE CASE 2 OPERATING SCENARIO $\ldots \ldots \ldots$ Addendum 8-8

3.0 REFERENCES $\ldots \ldots \ldots \ldots \ldots \ldots \ldots \ldots \ldots \ldots$ Addendum 8 . 33

\section{LIST OF TABLES}

1. Base Case Operating Scenario Evaluation $\ldots \ldots \ldots \ldots \ldots$ Addendum 8 -11

2. Alternative Case 1 Operating Scenario Evaluation $\ldots \ldots \ldots \ldots$ Addendum $8-17$

3. Alternative Case 2 Operating Scenario Evaluation $\ldots \ldots \ldots$ Addendum 8 - 23

4. Information Needs. . . . . . . . . . . . . Addendum 8-30 


\section{LIST OF TERMS}

DOE U.S. Department of Energy

DQO Data quality objective

ICD Interface Control Document

LAW Low-Activity Waste

M Molar (gmoles/liter)

M\&I Management and Integration

OSD Operating Specification Document

PHMC Project Hanford Management Contract(or)

PMBS Project Master Baseline Schedule

PSDQO Problem-Specific Data Quality Objectives

RL U.S. Department of Energy-Richland Operations

TANK T Refers to the contents from one tank, multiple tanks, or portions of one or more tanks that will be used to prepare a feed batch

TOC Total Organic Carbon

TRU Transuranic

TSC Tank Supernate Composite

TSCC Tank Saltcake Composite

TWRS Tank Waste Remediation System

TWRSO\&UP Tank Waste Remediation System Operation and Utilization Plan

WTC Whole tank composite 
HNF-2799

Revision 0

\section{ADDENDUM 8}

\section{APPLICATION OF "CONFIRM TANK T IS AN APPROPRIATE FEED SOURCE FOR LOW-ACTIVITY WASTE FEED BATCH " TO 241-SY-101 / BATCH 10}

\subsection{INTRODUCTION}

This addendum applies Revision 1 of "Confirm Tank $T$ is an Appropriate Feed Source for Low-Activity Waste Feed Batch $10^{\prime \prime}$ problem-specific data quality objectives (PSDQO) to tank 241-SY-101 / Batch 10.

This application of the data quality objective (DQO) is divided into a Base Case Operating Scenario and two alternative case operating scenarios. The Base Case homogenizes the waste in tank 241-SY-101 by mixing prior to transfer to tank 241-SY-102. Alternative Case 1 transfers supernate from tank 241-SY-101 without mixing followed by diluent addition, mixing, and settling of any remaining solids prior to transfer to tank 241-SY-102. Alternative Case 2 involves mixing the waste from tank 241-SY-101 with waste from tank 241-SY-103 in tank 241-SY-102. The waste from each tank would be a well-mixed, and diluted to allow transfer within operational limits. In all three cases, compatibility with the transuranic solids in tank 241-SY-102 must be evaluated.

\subsection{EVALUATION}

\subsection{BASE CASE OPERATING SCENARIO}

Translate the operating scenario into a series of process steps.

The base case operating scenario from the Tank Waste Remediation System Operation and Utilization Plan (TWRSO\&UP) (Kirkbride et al. 1997) includes the following steps to make up Batch 10:

- Empty supernate from 241-SY-102, leaving a 0.1-ML (10-in.) layer of supernate over the residual sludge layer. The supernate will be transferred cross-site into either tank 241-AN-102 or 241-AN-107 for eventual processing in 200 East Area.

- Homogenize the waste in 241-SY-101 using mixer pumps to resuspend the salt slurry. 
HNF-2799

Revision 0

- Transfer the homogenized waste in 241-SY-101 to 241-SY-102 until the receiver tank is full. During the transfer, the proper amount of diluent will be added to the waste at the transfer pump inlet.

- Repeat the above three steps as necessary until tank 241-SY-101 has been emptied.

Compatibility of the waste with the residual liquid in 241-SY-102 may need to be evaluated for the first transfer from 241-SY-101. Compatibility of 241-SY-101 waste with the transuranic sludge in 241-SY-102 is extremely important to ensure that envelope limits are not exceeded.

Define the waste that applies to each element in the decision rule.

Element 1, Dilution Ratio and Diluent Composition: this applies to the whole tank composite (WTC) over the temperature range of 25 to $65^{\circ} \mathrm{C}$.

Element 2, Transfer Requirements: There are several nearly identical transfers. They will be treated as one transfer. Transfer requirements apply to a WTC of the waste currently in 241-SY-101 after addition of the proper amount of diluent over the temperature range of 25 to $65^{\circ} \mathrm{C}$.

Element 3, Mixing Requirements: Two sets of mixing requirements apply. The first mixing requirement apply to blend of the diluted WTC for 241-SY-101 with the initial supernate layer and the sludge in 241-SY-102 over the temperature range of 25 to $65^{\circ} \mathrm{C}$. After the first transfer, the residual supernate is assumed to be the diluted WTC from 241-SY-101. Therefore the second mixing requirement applies to the diluted WTC for 241-SY-101 and the sludge in 241-SY-102 over the temperature range of 25 to $65^{\circ} \mathrm{C}$.

Element 4, Envelope and Quantity Requirements: the ultimate composition of Batch 10 will depend somewhat upon the residual supernate in 241-SY-102 and on any reactions between the sludge in 241-SY-102 and the WTC from 241-SY-101. The two composites from the mixing study (element 3 ) should be analyzed and evaluated against the Envelope A and C limits.

Element 5, Miscellaneous Inputs: These inputs apply to the WTC of 241-SY-101 or to changes in the operating scenario that may be imposed in the future.

Evaluate existing data and determine information needs.

Table 1 contains the evaluation of the base case operating scenario for all the elements of the decision rules found in Section 6 of the PSDQO (Certa and Jo 1998). The table lists each element taken from Section 4.0 of the PSDQO. For each element, the requirements specific to 241-SY-101 Batch 10 are listed. Each requirement is evaluated against existing data and the 
HNF-2799

Revision 0

remaining information needs are identified. The information needs are summarized in Table 4.

\subsection{ALTERNATIVE CASE 1 OPERATING SCENARIO}

Translate the operating scenario into a series of process steps.

The TWRSO\&UP (Kirkbride et al. 1997) recommended that process control issues be taken into account. This alternative case operating scenario was developed based on consideration of process control issues and is currently being evaluated and incorporated into the project master baseline schedule and corresponding logic diagrams. The steps that directly affect the composition of Batch 10 are listed below:

- Empty supernate from 241-SY-102, leaving a 0.1-ML (10-in.) layer of supernate over the residual sludge layer. The supernate will be transferred cross-site into either tank 241-AN-102 or 241-AN-107 for eventual processing in 200 East Area.

- Decant supernate from tank 241-SY-101 to 241-SY-102. During the transfer, the proper amount of diluent will be added to the waste at the transfer pump inlet.

- Repeat the above two steps until all supernate has been pumped from 241-SY-101.

- Add diluent to the salt slurry in 241-SY-101 and mix.

- Allow undissolved solids to settle in 241-SY-101.

- Transfer the liquid to 241-SY-102, leaving a 10-in heel in 241-SY-101. No additional diluent is expected to be needed for the transfer. It may be necessary to periodically transfer waste cross-site from 241-SY-102 to create space for the transfer.

Compatibility of the waste with the residual liquid in 241-SY-102 may need to be evaluated for the first transfer from 241-SY-101. Compatibility of 241-SY-101 waste with the transuranic sludge in 241-SY-102 is extremely important to ensure that envelope limits are not exceeded.

Define the waste that applies to each element in the decision rule.

Element 1, Dilution Ratio and Diluent Composition: this applies to the supernate composite and salt slurry composite of 241-SY-101 over the temperature range of 25 to $65^{\circ} \mathrm{C}$.

Element 2, Transfer Requirements: There are two types of transfers, supernate and salt slurry. The transfers should be evaluated over the temperature range of 25 to $65{ }^{\circ} \mathrm{C}$. 
Element 3, Mixing Requirements: Two mixing scenarios must be evaluated. The first is the mixing of supernate with the liquid and the sludge remaining in 241-SY-102. The second is the mixing of diluted salt slurry with the sludge in 241-SY-102. Mixing studies should be carried out over the temperature range of 25 to $65^{\circ} \mathrm{C}$.

Element 4, Envelope and Quantity Requirements: the ultimate composition of Batch 10 will depend somewhat upon the residual supernate in 241-SY-102 and on any reactions between the sludge in 241-SY-102 and the WTC from 241-SY-101. The two composites from the mixing study above should be analyzed and evaluated against the Envelope $\mathrm{A}$ and $\mathrm{C}$ limits.

Element 5, Miscellaneous Inputs: These inputs apply to the supernate and salt slurry composites for 241-SY-101 or to changes in the operating scenario that may be imposed in the future.

Table 2 contains the evaluation of the alternative case 1 operating scenario for all the elements of the decision rules found in Section 6 of the PSDQO (Certa and Jo). The table lists each element taken from Section 4.0 of the PSDQO (Certa and Jo). For each element, the requirements specific to $241-S Y-101 /$ Batch 10 are listed. Each requirement is evaluated against existing data and the remaining information needs are identified. The information needs are summarized in Table 4.

\subsection{ALTERNATIVE CASE 2 OPERATING SCENARIO}

Translate the operating scenario into a series of process steps.

The TWRSO\&UP (Kirkbride et al. 1997) recommended that process control issues be taken into account. This alternative case operating scenario was developed based on consideration of process control issues and is currently being evaluated and incorporated into the project master baseline schedule and corresponding logic diagrams. The steps that directly affect the composition of Batch 10 are listed below:

- Empty supernate from 241-SY-102, leaving a concentrated, 0.1-ML (10-in.) layer of supernate over the residual sludge layer. The supernate will be transferred cross-site into either tank 241-AN-102 or 241-AN-107 for eventual processing in 200 East Area.

- Homogenize the waste that is left in 241-SY-101 using mixer pumps to resuspend the salt slurry.

- Transfer the homogenized waste in 241-SY-101 to 241-SY-102. During the transfer, the proper amount of diluent will be added to the waste at the transfer pump inlet. 
- Homogenize the waste that is left in 241-SY-103 using mixer pumps to resuspend the salt slurry.

- Transfer the homogenized waste in 241-SY-103 to top off the tank 241-SY-102. During the transfer, the proper amount of diluent will be added to the waste at the transfer pump inlet.

- Pump the mixture of supernate waste from 241-SY-102 cross-site to 241-AN-102 or 241 -AN-107, leaving a $0.1-\mathrm{ML}$ (10-in) heel of supernate over the sludge in 241-SY-102.

Compatibility of the waste with the waste from 241-SY-101 to be evaluated for the first transfer from 241-SY-103. Compatibility of 241-SY-101 waste with the transuranic sludge in 241-SY-102 is extremely important to ensure that envelope limits are not exceeded.

Define the waste that applies to each element in the decision rule.

Element 1, Dilution Ratio and Diluent Composition: this applies to the WTC of 241-SY-101 over the temperature range of 25 to $65^{\circ} \mathrm{C}$.

Element 2, Transfer Requirements: Two transfers need to be evaluated. The first is the transfer of the WTC of the waste in 241-SY-101 to SY-102. The second is the transfer of the WTC of the waste in 241-SY-103 to SY-102 when it contains 241-SY-101 waste. The transfers should be evaluated after addition of the proper amount of diluent over the temperature range of 25 to $65^{\circ} \mathrm{C}$.

Element 3, Mixing Requirements: The two transfer scenarios need to be evaluated while mixing with the sludge in 241-SY-102 over the temperature range of 25 to $65^{\circ} \mathrm{C}$.

Element 4, Envelope and Quantity Requirements: the ultimate composition of Batch 10 will depend somewhat upon the residual supernate in 241-SY-102 and on any reactions between the sludge in 241-SY-102 and the WTC from 241-SY-101 and 241-SY-103. The two composites from the mixing evaluation (Element 3 ) should be analyzed and evaluated against the Envelope A and $\mathrm{C}$ limits.

Element 5, Miscellaneous Inputs: These inputs apply to the WTC of 241-SY-101 or to changes in the operating scenario that may be imposed in the future. 
HNF-2799

Revision 0

Evaluate existing data and determine information needs.

Table 3 contains the evaluation of the alternative case 2 operating scenario for all the elements of the decision rules found in Section 6 of the PSDQO (Certa and Jo). The table lists each element taken from Section 4.0 of the PSDQO (Certa and Jo). For each element, the requirements specific to 241-SY-101/Batch 10 are listed. Each requirement is evaluated against existing data and the remaining information needs are identified. The information needs are summarized in Table 4. 
HNF-2799

Revision 0

\begin{tabular}{|c|c|c|c|c|c|c|}
\hline 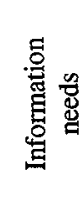 & 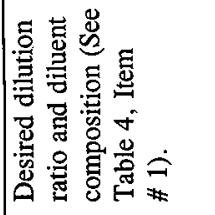 & & 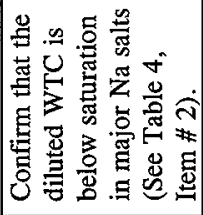 & 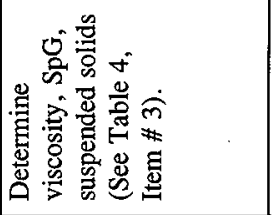 & \multicolumn{2}{|c|}{ 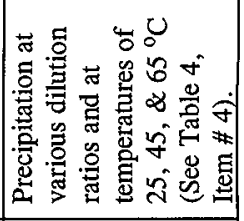 } \\
\hline 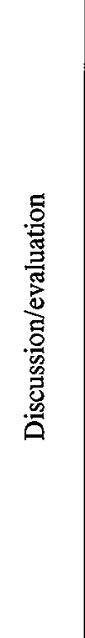 & 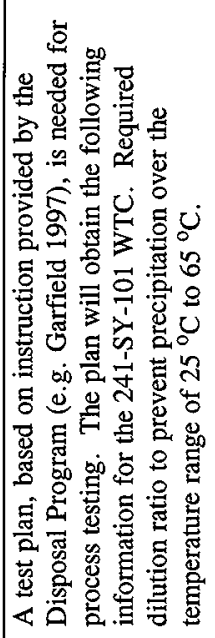 & 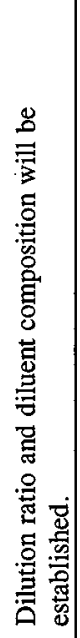 & 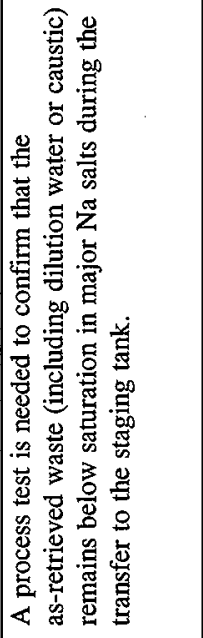 & 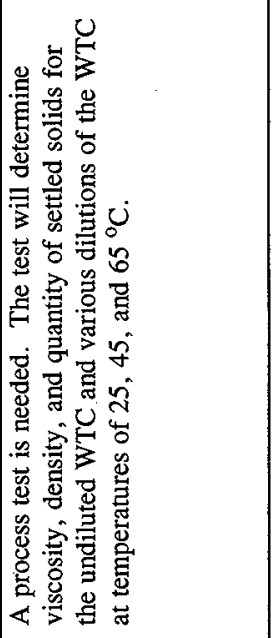 & 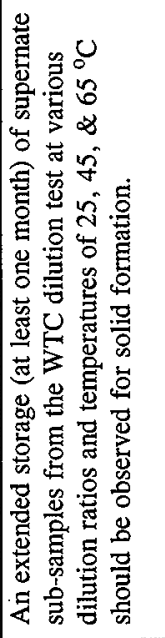 & 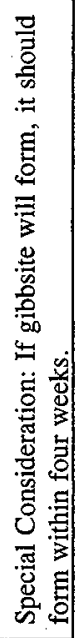 \\
\hline 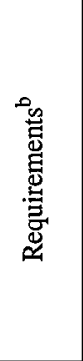 & 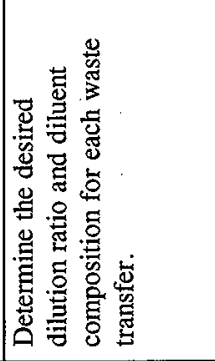 & & 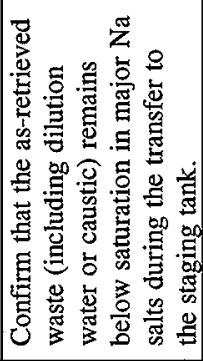 & 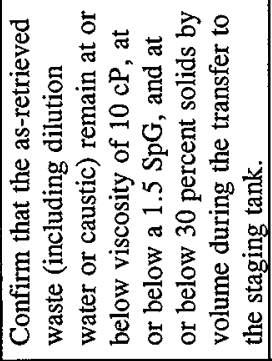 & 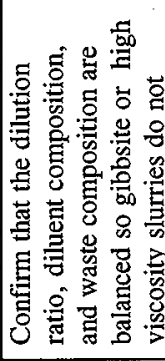 & 惫 \\
\hline 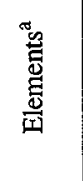 & 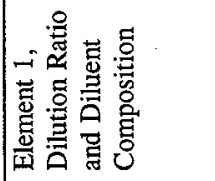 & & 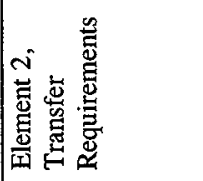 & & & \\
\hline
\end{tabular}


Table 1. Base Case Operating Scenario Evaluation. (8 Sheets)

\begin{tabular}{|c|c|c|c|}
\hline Elements $^{\mathrm{a}}$ & Requirements ${ }^{b}$ & Discussion/evaluation & $\begin{array}{l}\text { Information } \\
\text { needs }\end{array}$ \\
\hline \multirow[t]{3}{*}{$\begin{array}{l}\text { Element 3, } \\
\text { Mixing } \\
\text { Requirements }\end{array}$} & $\begin{array}{l}\text { Confirm that the portion of } \\
\text { the solids thought to be } \\
\text { soluble are soluble and that } \\
\text { they dissolve in a reasonable } \\
\text { amount of time. }\end{array}$ & $\begin{array}{l}\text { Dissolution kinetics at various dilutions and } \\
\text { temperatures needs to be measured. }\end{array}$ & $\begin{array}{l}\text { Determine } \\
\text { percent solids at } \\
\text { various dilutions } \\
\text { and temperatures } \\
\text { as a function of } \\
\text { time while } \\
\text { mixing.(See } \\
\text { Table 4, } \\
\text { Item \# 3). }\end{array}$ \\
\hline & $\begin{array}{l}\text { Confirm that the undissolved } \\
\text { solids settle and that they } \\
\text { settle in a reasonable amount } \\
\text { of time. }\end{array}$ & $\begin{array}{l}\text { Observation of settling times at various dilutions and } \\
\text { temperatures is needed. }\end{array}$ & $\begin{array}{l}\text { Determine } \\
\text { settling times at } \\
\text { various dilutions } \\
\text { and } \\
\text { temperatures. } \\
\text { (See Table 4, } \\
\text { Item \# 3). }\end{array}$ \\
\hline & $\begin{array}{l}\text { Confirm that the baseline } \\
\text { retrieval equipment that will } \\
\text { be used to mobilize and } \\
\text { transfer the waste is } \\
\text { consistent with the operating } \\
\text { scenario. }\end{array}$ & $\begin{array}{l}\text { Tank 241-SY-101 contains crust, convective, and } \\
\text { non-convective layers. The equipment required to } \\
\text { mobilize and retrieve the waste includes mixer pumps } \\
\text { and a transfer pump with water (and caustic) dilution } \\
\text { capability (Boston 1997). This is consistent with the } \\
\text { equipment identified in the base case operating } \\
\text { scenario (Kirkbride et al. 1997). }\end{array}$ & $\begin{array}{l}\text { No further } \\
\text { information } \\
\text { needed. }\end{array}$ \\
\hline
\end{tabular}


Table 1. Base Case Operating Scenario Evaluation. (8 Sheets)

\begin{tabular}{|c|c|c|c|}
\hline Elements $^{\mathrm{a}}$ & Requirements $^{b}$ & Discussion/evaluation & $\begin{array}{c}\text { Information } \\
\text { needs }\end{array}$ \\
\hline \multirow[t]{3}{*}{$\begin{array}{l}\text { Element } 4 \text { - Part } \\
\text { 1: Envelope } \\
\text { Requirements } \\
\text { These limits } \\
\text { apply to the } \\
\text { feed actually } \\
\text { delivered to the } \\
\text { private } \\
\text { contractors. }\end{array}$} & $\begin{array}{l}\text { Concentration limits for the } \\
\text { chemical and radionuclide } \\
\text { content of the feed (DOE-RL } \\
\text { 1996, Section C.6). } \\
\text { See Section } 2.0 \text { (Tables } 1 \\
\text { and 2) of main report for the } \\
\text { limits. }\end{array}$ & $\begin{array}{l}\text { Either Envelope } \mathrm{A} \text { or } \mathrm{C} \text { limits will apply to Batch } 10 \text {. } \\
\text { The limits are identical except that the Envelope } \mathrm{C} \\
\text { limits for TOC, } \mathrm{SO}_{4} \text {, TRU, and }{ }^{90} \mathrm{Sr} \text { are higher. } \\
\text { The TWRSO\&UP (Kirkbride et al. } 1997 \text {, Tables I-1 } \\
\text { and I-3) compared the point estimates }{ }^{\mathrm{a}} \text { of the } \\
\text { composition of the feed from } 241-\mathrm{SY}-101 \text { to the } \\
\text { Envelope C limits and indicate that the tank waste } \\
\text { meets all criteria. }\end{array}$ & $\begin{array}{l}\text { Chemical and } \\
\text { radionuclide. } \\
\text { analyses from } \\
\text { tests (See Table } \\
4 \text {, Item \# 5). }\end{array}$ \\
\hline & $\begin{array}{l}\text { Concentration limit for the } \\
\text { sodium concentration of the } \\
\text { feed: } 3 \mathrm{M} \geq[\mathrm{Na}] \geq 14 \mathrm{M} \\
\text { (DOE-RL } 1996, \text { Section } \\
\text { C. } 6 \text { ). }\end{array}$ & During process testing [Na] will be measured. & $\begin{array}{l}\text { [Na] } \\
\text { measurement } \\
\text { (See Table 4, } \\
\text { Item \# 6). }\end{array}$ \\
\hline & $\begin{array}{l}\text { Insoluble solids fraction limit } \\
\text { will not exceed } 5 \text { volume \% } \\
\text { (DOE-RL 1996, Section } \\
\text { C.6). }\end{array}$ & $\begin{array}{l}\text { During the process test, the quantity of solids for } \\
\text { various WTC dilutions will be measured over the } \\
\text { temperature range of } 25 \text { to } 65^{\circ} \mathrm{C} \text {. }\end{array}$ & $\begin{array}{l}\text { Insoluble solids } \\
\text { measurement } \\
\text { (See Table 4, } \\
\text { Item \# 7). }\end{array}$ \\
\hline
\end{tabular}


Table 1. Base Case Operating Scenario Evaluation. (8 Sheets)

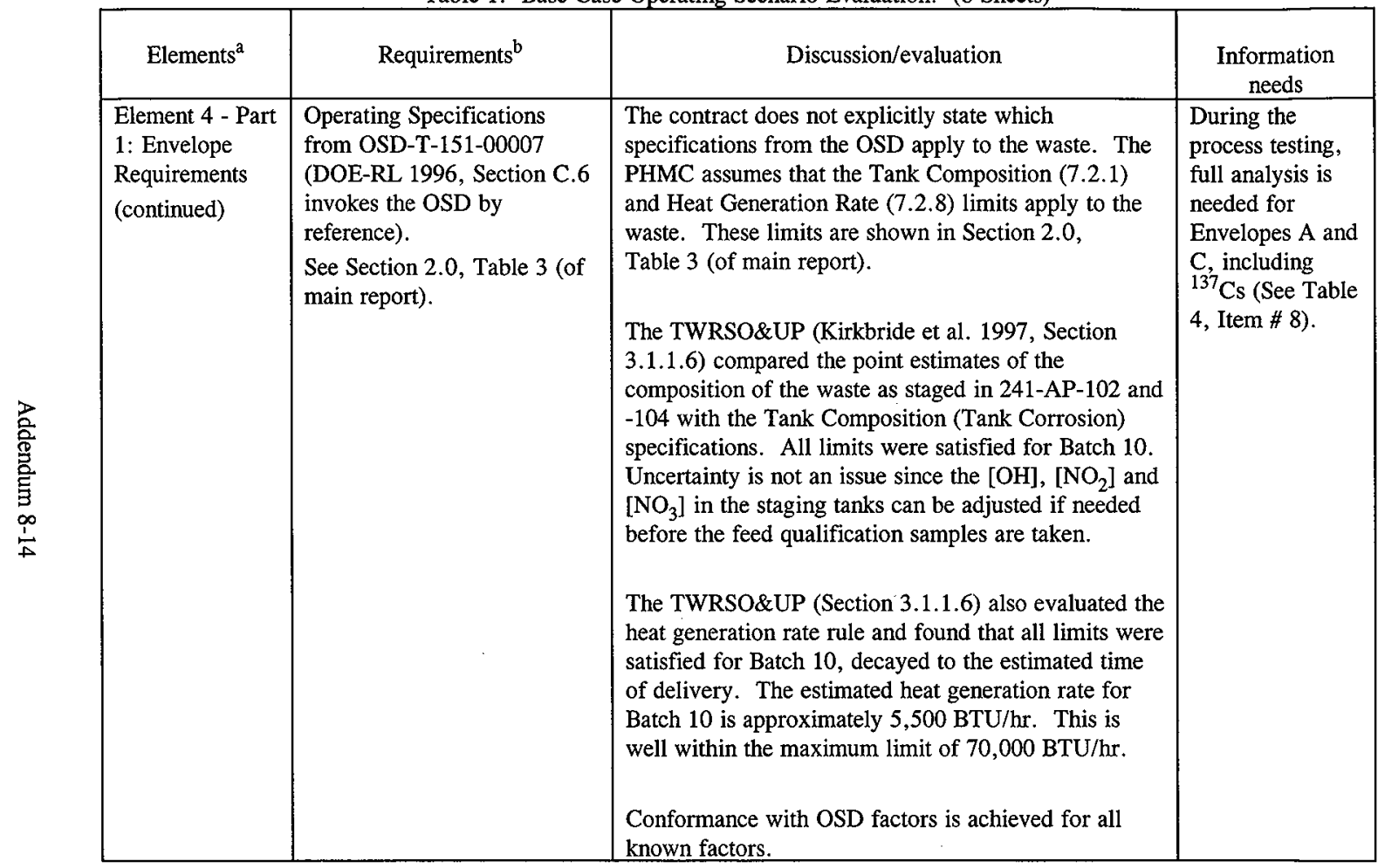


Table 1. Base Case Operating Scenario Evaluation. (8 Sheets)

\begin{tabular}{|c|c|c|c|}
\hline Elements $^{\mathrm{a}}$ & Requirements $^{\mathrm{b}}$ & Discussion/evaluation & $\begin{array}{c}\text { Information } \\
\text { needs }\end{array}$ \\
\hline \multirow[t]{2}{*}{$\begin{array}{l}\text { Element } 4 \text { - Part } \\
\text { 1: Envelope } \\
\text { Requirements } \\
\text { (continued) }\end{array}$} & $\begin{array}{l}\text { Maximum }{ }^{137} \mathrm{Cs} \\
\text { concentration of } 5.86 \mathrm{E} 10 \\
\mathrm{~Bq} / \text { liter }(6 \mathrm{Ci} / \mathrm{gal})\end{array}$ & $\begin{array}{l}\text { This limit is equivalent to } 1.59 \mathrm{E} 6 \mu \mathrm{Ci} / \mathrm{L} \text {. The OSD } \\
\text { limit of } 5.74 \mathrm{E} 5 \mu \mathrm{Ci} / \mathrm{L} \text { is more restrictive. } \\
\text { The tank characterization report estimates the }{ }^{137} \mathrm{Cs} \\
\text { concentration of } 342 \mu \mathrm{Ci} / \mathrm{g} \text { (Herting et al. } 1995 \text { ). } \\
\text { Clearly, the }{ }^{137} \mathrm{Cs} \text { concentration will be well below } \\
\text { the limit for this waste. } \\
\text { The tank characterization report estimates the }{ }^{90} \mathrm{Sr} \\
\text { concentration in } 241-\mathrm{SY}-101 \text { (Herting et. al. } 1995 \text { ) to } \\
\text { be } 19.3 \mu \mathrm{Ci} / \mathrm{L} \text {. Clearly, the }{ }^{90} \mathrm{Sr} \text { concentration is } \\
\text { well below the limit for this waste. } \\
\text { Conformance with OSD factors is achieved. }\end{array}$ & $\begin{array}{l}\text { Samples should } \\
\text { be analyzed } \\
\text { during process } \\
\text { testing, but all } \\
\text { indications are } \\
\text { that the levels of } \\
{ }^{137} \mathrm{Cs} \text { and }{ }^{90} \mathrm{Sr} \\
\text { are well below } \\
\text { the applicable } \\
\text { limits (See Table } \\
\text { 4, Item \# 5). }\end{array}$ \\
\hline & $\begin{array}{l}\text { The PHMC assumed } \\
\text { minimum limits to } \\
\text { distinguish between Envelope } \\
\mathrm{A} \text { and } \mathrm{C} \text { and between } \\
\text { Envelopes } \mathrm{A} \text { and B }\end{array}$ & $\begin{array}{l}\text { The discriminators for Envelopes } \mathrm{A} \text { and } \mathrm{C} \text { are } \mathrm{SO}_{4} \text {, } \\
\text { TOC, TRU, and }{ }^{90} \mathrm{Sr} \text {. }\end{array}$ & $\begin{array}{l}\text { Determine } \mathrm{SO}_{4} \text {, } \\
\text { TOC, TRU, and } \\
{ }^{90} \mathrm{Sr} \\
\text { concentrations } \\
\text { (See Table 4, } \\
\text { Item \# 9). }\end{array}$ \\
\hline
\end{tabular}


Table 1. Base Case Operating Scenario Evaluation. (8 Sheets)

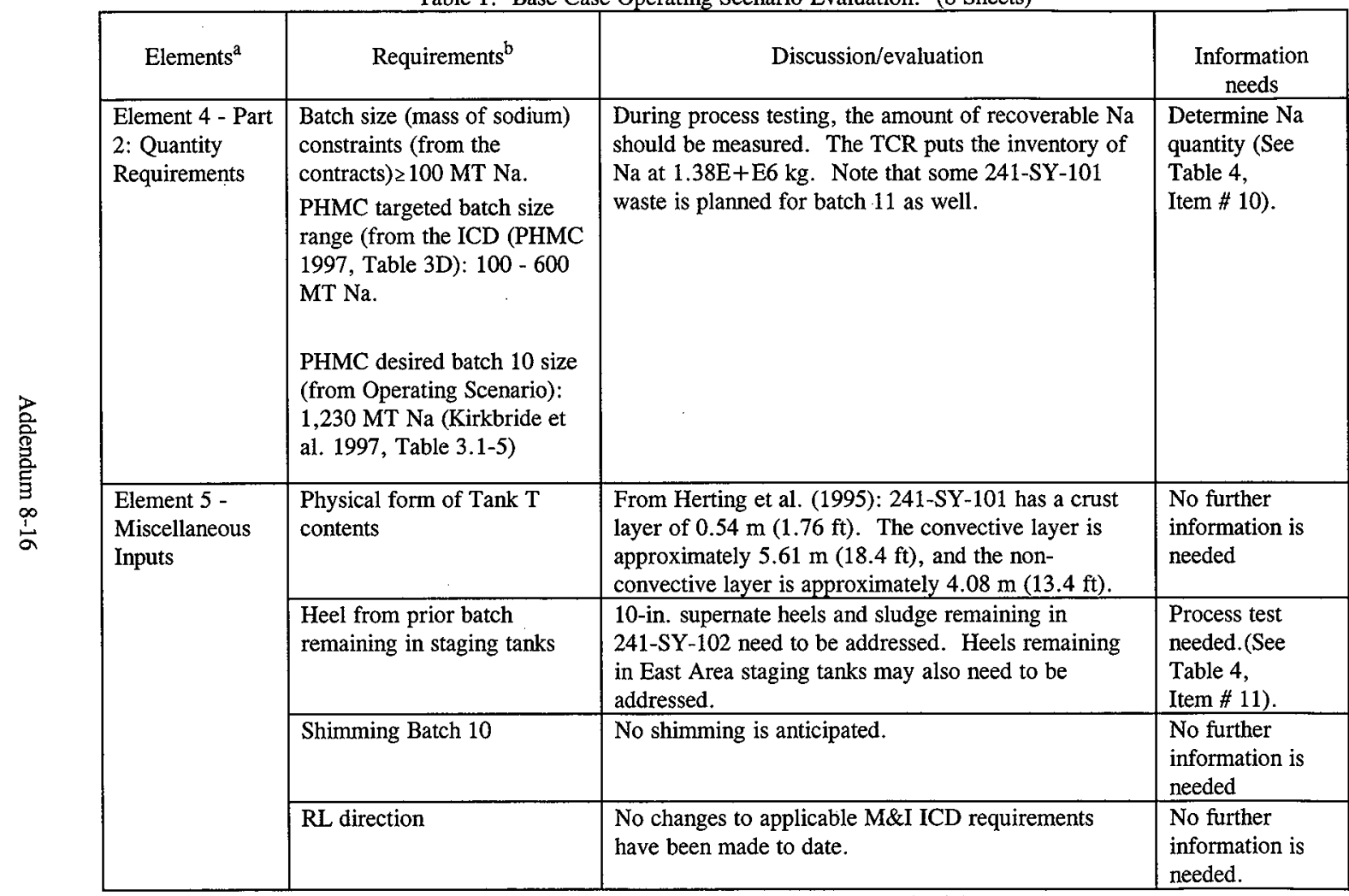

a. Elements are taken from the Decision Rule statement in Section 4.0 of PSDQO-01.

b. Requirements are taken from Sections 4.1, 4.2, 4.3, 4.4, and 4.5 of PSDQO-01. 
Table 2. Alternative Case 1 Operating Scenario Evaluation. (6 Sheets)

\begin{tabular}{|c|c|c|c|}
\hline Elements $^{\mathrm{a}}$ & Requirements $^{\mathrm{b}}$ & Discussion/evaluation & $\begin{array}{l}\text { Information } \\
\text { needs }\end{array}$ \\
\hline $\begin{array}{l}\text { Element 1, } \\
\text { Dilution Ratio } \\
\text { and Diluent } \\
\text { Composition }\end{array}$ & $\begin{array}{l}\text { Determine the desired } \\
\text { dilution ratio and diluent } \\
\text { composition for each waste } \\
\text { transfer. }\end{array}$ & $\begin{array}{l}\text { Process testing of the supernate composite and of diluted } \\
\text { salt slurry composite is needed at various dilutions over } \\
\text { the temperature range of } 25^{\circ} \mathrm{C} \text { to } 65^{\circ} \mathrm{C} \text {. }\end{array}$ & $\begin{array}{l}\text { Desired dilution } \\
\text { ratio and diluent } \\
\text { composition (See } \\
\text { Table 4, } \\
\text { Item \# 12) }\end{array}$ \\
\hline \multirow[t]{3}{*}{$\begin{array}{l}\text { Element 2, } \\
\text { Transfer } \\
\text { Requirements }\end{array}$} & $\begin{array}{l}\text { Confirm that the as-retrieved } \\
\text { waste (including dilution } \\
\text { water or caustic) remains } \\
\text { below saturation in major } \mathrm{Na} \\
\text { salts during the transfer to } \\
\text { the staging tank. }\end{array}$ & $\begin{array}{l}\text { A process test is needed to confirm that the as-retrieved } \\
\text { waste streams (including dilution water or caustic) remain } \\
\text { below saturation in major Na salts during the transfer to } \\
\text { the staging tank. The two streams are the supernate and } \\
\text { salt slurry from the tank. Testing should be conducted at } \\
\text { various dilutions and temperatures. }\end{array}$ & $\begin{array}{l}\text { Confirm that the } \\
\text { two streams are } \\
\text { below saturation } \\
\text { in major Na salts } \\
\text { (See Table 4, } \\
\text { Item \# 13). }\end{array}$ \\
\hline & $\begin{array}{l}\text { Confirm that the as-retrieved } \\
\text { waste (including dilution } \\
\text { water or caustic) remain at } \\
\text { or below viscosity of } 10 \mathrm{cP} \text {, } \\
\text { at or below a } 1.5 \mathrm{SpG} \text {, and } \\
\text { at or below } 30 \text { percent solids } \\
\text { by volume during the } \\
\text { transfer to the staging tank. }\end{array}$ & $\begin{array}{l}\text { Process testing of the supernate and salt slurry at various } \\
\text { dilutions and temperatures is needed. Viscosity, specific } \\
\text { gravity, and volume percent solids data are needed. }\end{array}$ & $\begin{array}{l}\text { Determine } \\
\text { viscosity, } \mathrm{SpG} \text {, } \\
\text { suspended solids } \\
\text { (See Table } 4 \text {, } \\
\text { Item \# 14). }\end{array}$ \\
\hline & $\begin{array}{l}\text { Confirm that the dilution } \\
\text { ratio, diluent composition, } \\
\text { and waste composition are } \\
\text { balanced so gibbsite or high } \\
\text { viscosity slurries do not } \\
\text { precipitate. }\end{array}$ & $\begin{array}{l}\text { An extended storage (at least one month) of supernate } \\
\text { and salt slurry subsamples from the dilution should be } \\
\text { observed for solid formation over the temperature range } \\
\text { of } 25 \text { to } 65{ }^{\circ} \mathrm{C} \text {. } \\
\text { Special Consideration: If gibbsite will form, it should } \\
\text { form within four weeks. }\end{array}$ & $\begin{array}{l}\text { Precipitation at } \\
\text { various dilution } \\
\text { ratios over the } \\
\text { temperature } \\
\text { range of } 25 \text { to } 65 \\
{ }^{\circ} \mathrm{C} \text { (See Table } 4 \text {, } \\
\text { Item \# 15). }\end{array}$ \\
\hline
\end{tabular}


Table 2. Alternative Case 1 Operating Scenario Evaluation. (6 Sheets)

\begin{tabular}{|c|c|c|c|}
\hline Elements ${ }^{\mathrm{a}}$ & Requirements $^{b}$ & Discussion/evaluation & $\begin{array}{l}\text { Information } \\
\text { needs }\end{array}$ \\
\hline \multirow[t]{3}{*}{$\begin{array}{l}\text { Element } 3 \text {, } \\
\text { Mixing } \\
\text { Requirements }\end{array}$} & $\begin{array}{l}\text { Confirm that the portion of } \\
\text { the solids thought to be } \\
\text { soluble are soluble and that } \\
\text { they dissolve in a reasonable } \\
\text { amount of time. }\end{array}$ & $\begin{array}{l}\text { Dissolution kinetics at various dilutions and temperatures } \\
\text { needs to be measured. } \\
\text { Note: Confirmation that a mixer pump can provide the } \\
\text { necessary amount of mixing to dissolve the solids in the } \\
\text { tank in a reasonable amount of time is within the scope } \\
\text { of the Equipment Design PSDQO. }\end{array}$ & $\begin{array}{l}\text { Determine } \\
\text { percent solids at } \\
\text { various dilutions } \\
\text { and temperatures } \\
\text { as a function of } \\
\text { time while } \\
\text { mixing (See } \\
\text { Table } 4 \text {, } \\
\text { Item \# 15). }\end{array}$ \\
\hline & $\begin{array}{l}\text { Confirm that the undissolved } \\
\text { solids settle and that they } \\
\text { settle in a reasonable amount } \\
\text { of time. }\end{array}$ & $\begin{array}{l}\text { Observation of settling times at various dilutions and } \\
\text { temperatures is needed. }\end{array}$ & $\begin{array}{l}\text { Determine } \\
\text { settling times at } \\
\text { various dilutions } \\
\text { and } \\
\text { temperatures. } \\
\text { See Table 4, } \\
\text { Item \# 15) }\end{array}$ \\
\hline & $\begin{array}{l}\text { Confirm that the baseline } \\
\text { retrieval equipment that will } \\
\text { be used to mobilize and } \\
\text { transfer the waste is } \\
\text { consistent with the operating } \\
\text { scenario. }\end{array}$ & $\begin{array}{l}\text { Tank 241-SY-101 contains crust, convective, and non- } \\
\text { convective layers. The equipment required to mobilize } \\
\text { and retrieve the waste includes mixer pumps and a } \\
\text { transfer pump with water (and caustic) dilution capability } \\
\text { (Boston 1997). This is consistent with the equipment } \\
\text { identified in the base case operating scenario (Kirkbride } \\
\text { et al. 1997). }\end{array}$ & $\begin{array}{l}\text { No further } \\
\text { information } \\
\text { needed. }\end{array}$ \\
\hline
\end{tabular}


Table 2. Alternative Case 1 Operating Scenario Evaluation. (6 Sheets)

\begin{tabular}{|c|c|c|c|}
\hline Elements $^{\mathrm{a}}$ & Requirements $^{b}$ & Discussion/evaluation & $\begin{array}{l}\text { Information } \\
\text { needs }\end{array}$ \\
\hline \multirow{3}{*}{$\begin{array}{l}\text { Element } 4 \text { - Part } \\
\text { 1: Envelope } \\
\text { Requirements } \\
\text { These limits } \\
\text { apply to the feed } \\
\text { actually } \\
\text { delivered to the } \\
\text { private } \\
\text { contractors. }\end{array}$} & $\begin{array}{l}\text { Concentration limits for the } \\
\text { chemical and radionuclide } \\
\text { content of the feed (DOE-RL } \\
\text { 1996, Section C.6). } \\
\text { See Section } 2.0 \text {, Tables } 1 \\
\text { and } 2 \text { (in main report) for } \\
\text { the limits. }\end{array}$ & $\begin{array}{l}\text { Either Envelope } \mathrm{A} \text { or } \mathrm{C} \text { limits will apply to Batch } 10 \text {. } \\
\text { The limits are identical except that the Envelope } \mathrm{C} \text { limits } \\
\text { for TOC, } \mathrm{SO}_{4} \text {, TRU, and }{ }^{90} \mathrm{Sr} \text { are higher. } \\
\text { The TWRSO\&UP (Kirkbride et al. } 1997 \text {, Tables I-1 and } \\
\text { I-3) compared the point estimates }{ }^{\perp} \text { of the composition of } \\
\text { the feed from } 241-S Y-101 \text { to the Envelope C limits and } \\
\text { indicate that the tank waste meets all criteria. }\end{array}$ & $\begin{array}{l}\text { Chemical and } \\
\text { radionuclide } \\
\text { analyses from } \\
\text { process testing } \\
\text { (See Table } 4 \text {, } \\
\text { Item \# 16). }\end{array}$ \\
\hline & $\begin{array}{l}\text { Concentration limit for the } \\
\text { sodium concentation of the } \\
\text { feed: } 3 \underline{M} \geq[N a] \leq 14 \underline{M} \\
\text { (DOE-RL } 1996, \text { Section } \\
\text { C.6) }\end{array}$ & During process testing $[\mathrm{Na}]$ will be measured. & $\begin{array}{l}{[\mathrm{Na}]} \\
\text { measurement } \\
\text { (See Table } 4, \\
\text { Item 17.) }\end{array}$ \\
\hline & $\begin{array}{l}\text { Operating Specifications } \\
\text { from OSD-T-151-00007 } \\
\text { (DOE-RL 1996, Section C. } 6 \\
\text { invokes the OSD by } \\
\text { reference). } \\
\text { See Section 2.0, Table } 3 \text { (of } \\
\text { main report). }\end{array}$ & $\begin{array}{l}\text { The TWRSO\&UP (Kirkbride et al. 1997, Section } \\
\text { 3.1.1.6) compared the point estimates of the composition } \\
\text { of the waste as staged in } 241-A P-102 \text { and }-104 \text { with the } \\
\text { corrosion, criticality, TRU, heat generation, and } \\
\text { flammable gas SpG specifications. All limits were } \\
\text { satisfied for Batch } 10 \text {. Nevertheless, the envelope } \\
\text { analytes should be analyzed to confirm this prediction. } \\
\text { Conformance with OSD factors is expected to be } \\
\text { achieved. }\end{array}$ & $\begin{array}{l}\text { During the } \\
\text { process testing, } \\
\text { full analysis is } \\
\text { needed for } \\
\text { Envelope A and } \\
\text { C. (See Table } \\
\text { 4, Item \# 18). }\end{array}$ \\
\hline
\end{tabular}

\footnotetext{
${ }^{1}$ These point estimates were based on a thermodynamic model (ESP) that was used to estimate the liquid phase composition of the
} waste. 
Table 2. Alternative Case 1 Operating Scenario Evaluation. (6 Sheets)

\begin{tabular}{|c|c|c|c|}
\hline Elements $^{\mathrm{a}}$ & Requirements $^{b}$ & Discussion/evaluation & $\begin{array}{l}\text { Information } \\
\text { needs }\end{array}$ \\
\hline \multirow[t]{2}{*}{$\begin{array}{l}\text { Element } 4 \text { - Part } \\
\text { 1: Envelope } \\
\text { Requirements } \\
\text { (continued) }\end{array}$} & $\begin{array}{l}\text { Maximum }{ }^{137} \mathrm{Cs} \\
\text { concentration of } 5.86 \mathrm{E} 10 \\
\text { Bq/liter }(6 \mathrm{Ci} / \mathrm{gal}) \text {. } \\
\text { Maximum }{ }^{90} \mathrm{Sr} \text { concentration } \\
\text { of } 4.04 \mathrm{E} 5 \mu \mathrm{Ci} / \mathrm{L} \text {. }\end{array}$ & $\begin{array}{l}\text { This limit is equivalent to } 1.59 \mathrm{E} 6 \mu \mathrm{Ci} / \mathrm{L} \text {. The OSD limit } \\
\text { of } 5.74 \mathrm{E} 5 \mu \mathrm{Ci} / \mathrm{L} \text { is more restrictive. } \\
\text { The tank characterization report estimates the }{ }^{137} \mathrm{Cs} \\
\text { concentration of } 342 \mu \mathrm{Ci} / \mathrm{g} \text { (Herting et al. } 1995 \text { ). } \\
\text { Clearly, the }{ }^{137} \mathrm{Cs} \text { concentration will be well below the } \\
\text { limit for this waste. } \\
\text { The tank characterization report estimates the }{ }^{90} \mathrm{Sr} \\
\text { concentration in } 241-\mathrm{SY}-101 \text { (Herting et. al. } 1995 \text { ) to be } \\
19.3 \mu \mathrm{Ci} / \mathrm{L} \text {. Clearly, the }{ }^{90} \mathrm{Sr} \text { concentration is well } \\
\text { below the limit for this waste. } \\
\text { Conformance with OSD factors is achieved. }\end{array}$ & $\begin{array}{l}\text { Samples should } \\
\text { be analyzed } \\
\text { during the } \\
\text { process testing, } \\
\text { but all } \\
\text { indications are } \\
\text { that the levels of } \\
{ }^{137} \mathrm{Cs} \text { and }{ }^{90} \mathrm{Sr} \\
\text { are well below } \\
\text { applicable limits. } \\
\text { (See Table } 4 \text {, } \\
\text { Item \# 16). }\end{array}$ \\
\hline & $\begin{array}{l}\text { The PHMC assumed } \\
\text { minimum limits to } \\
\text { distinguish between } \\
\text { Envelope } A \text { and } C \text { and } \\
\text { between Envelopes } A \text { and B }\end{array}$ & $\begin{array}{l}\text { The discriminators for Envelopes } \mathrm{A} \text { and } \mathrm{C} \text { are } \mathrm{SO}_{4} \text {, } \\
\text { TOC, TRU, and }{ }^{90} \mathrm{Sr} \text {. }\end{array}$ & $\begin{array}{l}\text { Determine are } \\
\mathrm{SO}_{4}, \mathrm{TOC}, \\
\mathrm{TRU}, \text { and }{ }^{90} \mathrm{Sr} \\
\text { concentrations. } \\
\text { (See Table } 4 \text {, } \\
\text { Item \# 16). }\end{array}$ \\
\hline
\end{tabular}


Table 2. Alternative Case 1 Operating Scenario Evaluation. (6 Sheets)

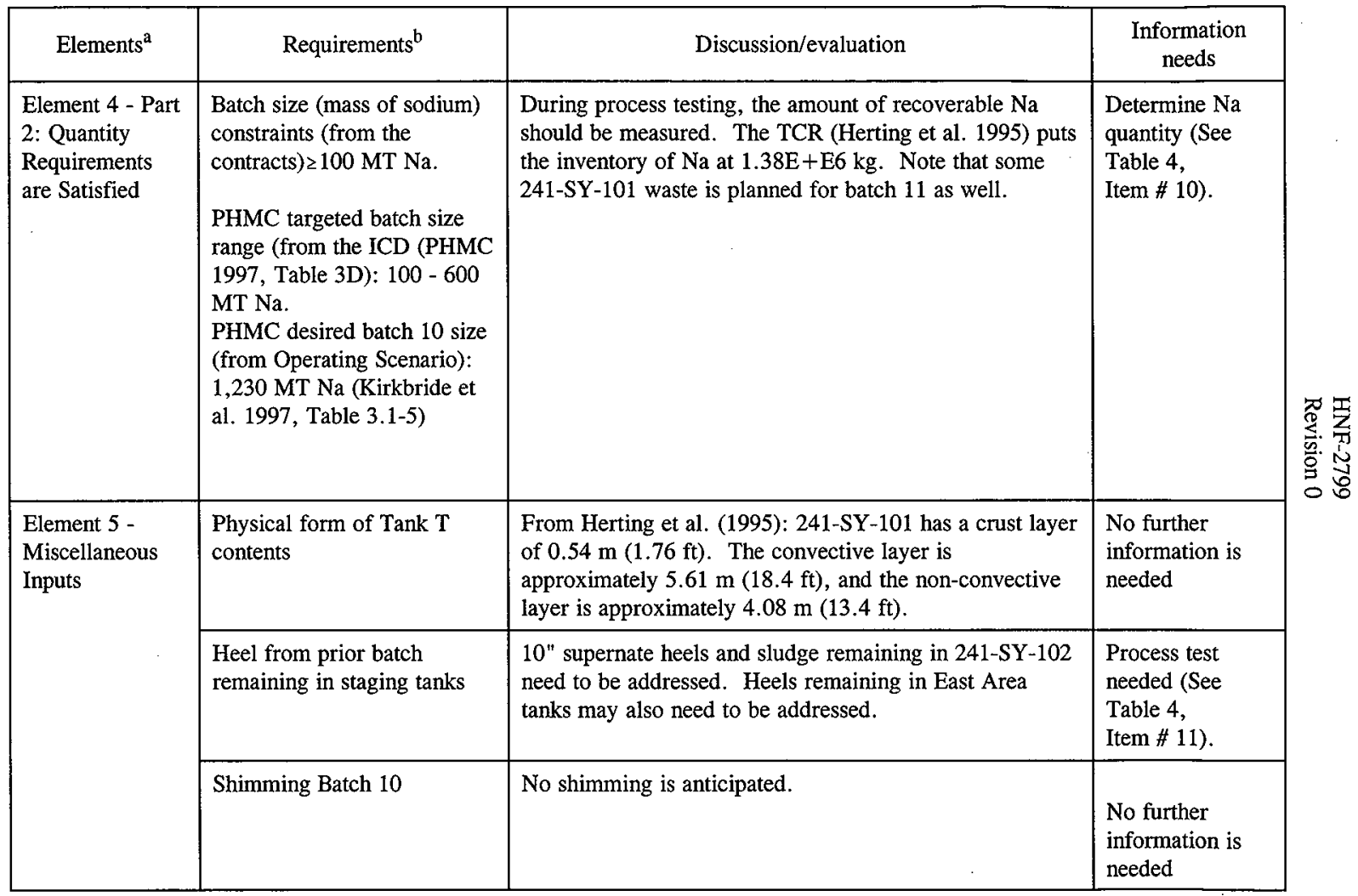


Table 2. Alternative Case 1 Operating Scenario Evaluation. (6 Sheets)

\begin{tabular}{|l|l|l|l|}
\hline \multicolumn{1}{|c|}{ Elements $^{\mathrm{a}}$} & \multicolumn{1}{|c|}{ Requirements $^{\mathrm{b}}$} & \multicolumn{1}{c|}{ Discussion/evaluation } & \multicolumn{1}{c|}{$\begin{array}{l}\text { Information } \\
\text { needs }\end{array}$} \\
\hline $\begin{array}{l}\text { Element 5 - } \\
\begin{array}{l}\text { Miscellaneous } \\
\text { Inputs } \\
\text { (continued) }\end{array}\end{array}$ & RL direction & $\begin{array}{l}\text { No changes to applicable M\&I ICD requirements have } \\
\text { been made to date. }\end{array}$ & $\begin{array}{l}\text { No further } \\
\text { information is } \\
\text { needed }\end{array}$ \\
\hline
\end{tabular}

${ }^{2}$ Elements are taken from the Decision Rule statement in Section 6.0 of PSDQO-01.

${ }^{b}$ Requirements are taken from Sections 4.1, 4.2, 4.3, 4.4, and 4.5 of PSDQO-01. 
Table 3. Alternative Case 2 Operating Scenario Evaluation. (9 Sheets)

\begin{tabular}{|c|c|c|c|}
\hline Elements $^{a}$ & Requirements $^{b}$ & Discussion/evaluation & $\begin{array}{c}\text { Information } \\
\text { needs }\end{array}$ \\
\hline $\begin{array}{l}\text { Element 1, } \\
\text { Dilution Ratio } \\
\text { and Diluent } \\
\text { Composition }\end{array}$ & $\begin{array}{l}\text { Determine the desired } \\
\text { dilution ratio and diluent } \\
\text { composition for each waste } \\
\text { transfer. }\end{array}$ & $\begin{array}{l}\text { A test plan, based on instruction provided by the } \\
\text { Disposal Program (e.g. Garfield 1997), is needed for } \\
\text { process testing. The plan will obtain the following } \\
\text { information for the } 241-\mathrm{SY}-101 \mathrm{WTC} \text {. Required dilution } \\
\text { ratio to prevent precipitation over the temperature range } \\
\text { of } 25^{\circ} \mathrm{C} \text { to } 65^{\circ} \mathrm{C} \text {. } \\
\text { Process testing for } 241-\mathrm{SY}-101 \text { WTC will be completed } \\
\text { per } 241-\mathrm{SY}-101 \text { addendum. }\end{array}$ & $\begin{array}{l}\text { Desired dilution } \\
\text { ratio and diluent } \\
\text { composition (See } \\
\text { Table 4, } \\
\text { Item \# 1). }\end{array}$ \\
\hline \multirow[t]{2}{*}{$\begin{array}{l}\text { Element 2, } \\
\text { Transfer } \\
\text { Requirements }\end{array}$} & $\begin{array}{l}\text { Confirm that the as-retrieved } \\
\text { waste (including dilution } \\
\text { water or caustic) remains } \\
\text { below saturation in major } \mathrm{Na} \\
\text { salts during the transfer to } \\
\text { the staging tank. }\end{array}$ & $\begin{array}{l}\text { A process test is needed to confirm that the as-retrieved } \\
\text { waste (WTC including dilution water or caustic) remains } \\
\text { below saturation in major Na salts during the transfer to } \\
\text { the staging tank. } \\
\text { Process testing for } 241-S Y-101 \text { WTC will be completed } \\
\text { per } 241-S Y-101 \text { addendum. }\end{array}$ & $\begin{array}{l}\text { Confirm that the } \\
\text { diluted WTC is } \\
\text { below saturation } \\
\text { in major Na salts } \\
\text { (See Table 4, } \\
\text { Item \# 2). }\end{array}$ \\
\hline & $\begin{array}{l}\text { Confirm that the as-retrieved } \\
\text { waste (including dilution } \\
\text { water or caustic) remain at } \\
\text { or below viscosity of } 10 \mathrm{cP} \text {, } \\
\text { at or below a } 1.5 \mathrm{SpG} \text {, and } \\
\text { at or below } 30 \text { percent solids } \\
\text { by volume during the } \\
\text { transfer to the staging tank. }\end{array}$ & $\begin{array}{l}\text { A process test is needed. The test will determine } \\
\text { viscosity, density, and quantity of settled solids for the } \\
\text { undiluted WTC and various dilutions of the WTC at } \\
\text { temperatures of } 25,45 \text {, and } 65^{\circ} \mathrm{C} \text {. } \\
\text { Process testing for } 241-\mathrm{SY}-101 \text { WTC will be completed } \\
\text { per } 241-\mathrm{SY}-101 \text { addendum. }\end{array}$ & $\begin{array}{l}\text { Determine } \\
\text { viscosity, SpG, } \\
\text { suspended solids } \\
\text { (See Table 4, } \\
\text { Item \# 3). }\end{array}$ \\
\hline
\end{tabular}


Table 3. Alternative Case 2 Operating Scenario Evaluation. (9 Sheets)

\begin{tabular}{|c|c|c|c|}
\hline Elements $^{\mathrm{a}}$ & Requirements ${ }^{b}$ & Discussion/evaluation & $\begin{array}{l}\text { Information } \\
\text { needs }\end{array}$ \\
\hline $\begin{array}{l}\text { Element 2, } \\
\text { Transfer } \\
\text { Requirements } \\
\text { (contiued) }\end{array}$ & $\begin{array}{l}\text { Confirm that the dilution } \\
\text { ratio, diluent composition, } \\
\text { and waste composition are } \\
\text { balanced so gibbsite or high } \\
\text { viscosity slurries do not } \\
\text { precipitate }\end{array}$ & $\begin{array}{l}\text { An extended storage (at least one month) of supernate } \\
\text { sub-samples from the WTC dilution test at various } \\
\text { dilution ratios and temperatures of } 25,45 \text {, and } 65^{\circ} \mathrm{C} \\
\text { should be observed for solid formation. } \\
\text { Special Consideration: If gibbsite will form, it should } \\
\text { form within four weeks. }\end{array}$ & $\begin{array}{l}\text { Precipitation at } \\
\text { various dilution } \\
\text { ratios and at } \\
\text { temperatures of } \\
25,45, \& 65^{\circ} \mathrm{C} \\
\text { (See Table } 4 \text {, } \\
\text { Item \# 4). }\end{array}$ \\
\hline $\begin{array}{l}\text { Element 3, } \\
\text { Mixing } \\
\text { Requirements }\end{array}$ & $\begin{array}{l}\text { Confirm that the portion of } \\
\text { the solids thought to be } \\
\text { soluble are soluble and that } \\
\text { they dissolve in a reasonable } \\
\text { amount of time. }\end{array}$ & $\begin{array}{l}\text { Dissolution kinetics at various dilutions and temperatures } \\
\text { needs to be measured. } \\
\text { Note: Confirmation that a mixer pump can provide the } \\
\text { necessary amount of mixing to dissolve the solids in the } \\
\text { tank in a reasonable amount of time is within the scope } \\
\text { of the Equipment Design PSDQO. } \\
\text { For this alternative, the waste will be combined with } \\
\text { waste from } 241-\text { SY-103. Therefore, compatibility with } \\
\text { the } 241-S Y-101 \text { WTC is necessary. }\end{array}$ & $\begin{array}{l}\text { Determine } \\
\text { percent solids at } \\
\text { various dilutions } \\
\text { and temperatures } \\
\text { as a function of } \\
\text { time while } \\
\text { mixing (See } \\
\text { Table 4, } \\
\text { Item \# 19). } \\
\text { Confirm } \\
\text { compatibility } \\
\text { with 241-SY-101 } \\
\text { WTC (See Table } \\
\text { 4, Item \# 20). } \\
\end{array}$ \\
\hline
\end{tabular}


Table 3. Alternative Case 2 Operating Scenario Evaluation. (9 Sheets)

\begin{tabular}{|c|c|c|c|}
\hline Elements $^{\mathrm{a}}$ & Requirements ${ }^{b}$ & Discussion/evaluation & $\begin{array}{l}\text { Information } \\
\text { needs }\end{array}$ \\
\hline \multirow{2}{*}{$\begin{array}{l}\text { Element } 4 \text { - Part } \\
\text { 1: Envelope } \\
\text { Requirements } \\
\text { These limits } \\
\text { apply to the } \\
\text { feed actually } \\
\text { delivered to the } \\
\text { private } \\
\text { contractors. }\end{array}$} & $\begin{array}{l}\text { Confirm that the undissolved } \\
\text { solids settle and that they } \\
\text { settle in a reasonable amount } \\
\text { of time. }\end{array}$ & $\begin{array}{l}\text { Observation of settling times at various dilutions and } \\
\text { temperatures is needed. }\end{array}$ & $\begin{array}{l}\text { Determine } \\
\text { settling times at } \\
\text { various dilutions } \\
\text { and temperatures } \\
\text { (See Table 4, } \\
\text { Item \# 21). }\end{array}$ \\
\hline & $\begin{array}{l}\text { Confirm that the baseline } \\
\text { retrieval equipment that will } \\
\text { be used to mobilize and } \\
\text { transfer the waste is } \\
\text { consistent with the operating } \\
\text { scenario. }\end{array}$ & $\begin{array}{l}\text { Tank } 241-S Y-101 \text { contains crust, supernate, and salt } \\
\text { slurry/sludge layers. The equipment required to mobilize } \\
\text { and retrieve the waste includes mixer pumps and a } \\
\text { transfer pump with water (and caustic) dilution capability } \\
\text { (Boston 1997). This is consistent with the equipment } \\
\text { identified in the base case operating scenario (Kirkbride } \\
\text { et al. 1997). }\end{array}$ & $\begin{array}{l}\text { No further } \\
\text { information } \\
\text { needed. }\end{array}$ \\
\hline
\end{tabular}


Table 3. Alternative Case 2 Operating Scenario Evaluation. ( 9 Sheets)

\begin{tabular}{|c|c|c|c|}
\hline Elements $^{\mathrm{a}}$ & Requirements $^{b}$ & Discussion/evaluation & $\begin{array}{l}\text { Information } \\
\text { needs }\end{array}$ \\
\hline \multirow[t]{3}{*}{$\begin{array}{l}\text { Element } 4 \text { - Part } \\
\text { 1: Envelope } \\
\text { Requirements } \\
\text { (continued) }\end{array}$} & $\begin{array}{l}\text { Concentration limits for the } \\
\text { chemical and radionuclide } \\
\text { content of the feed (DOE-RL } \\
\text { 1996, Section C.6). }\end{array}$ & $\begin{array}{l}\text { Either Envelope A or C limits will apply to Batch } 10 \text {. } \\
\text { The limits are identical except that the Envelope C limits } \\
\text { for TOC, } \mathrm{SO}_{4}, \mathrm{TRU} \text {, and }{ }^{90} \mathrm{Sr} \text { are higher. } \\
\text { The TWRSO\&UP (Kirkbride et al. 1997, Tables I-1 and } \\
\text { I-3) compared the point estimates }{ }^{1} \text { of the composition of } \\
\text { the feed from } 241-\mathrm{SY}-101 \text { to the Envelope C limits and } \\
\text { indicate that the tank waste meets all criteria. }\end{array}$ & $\begin{array}{l}\text { Chemical and } \\
\text { radionuclide } \\
\text { analyses from } \\
\text { tests (See Table } \\
4 \text {, Item \# 22). }\end{array}$ \\
\hline & $\begin{array}{l}\text { Concentration limit for the } \\
\text { sodium concentration of the } \\
\text { feed: } 3 \underline{M} \geq[\mathrm{Na}] \geq 14 \mathrm{M} \\
\text { (DOE-RL } 1996 \text {, Section } \\
\text { C.6). }\end{array}$ & During process testing [Na] will be measured. & $\begin{array}{l}{[\mathrm{Na}]} \\
\text { measurement } \\
\text { (See Table 4, } \\
\text { Item \# 22). }\end{array}$ \\
\hline & $\begin{array}{l}\text { Insoluble solids fraction limit } \\
\text { will not exceed } 5 \text { volume \% } \\
\text { (DOE-RL 1996, Section } \\
\text { C.6). }\end{array}$ & $\begin{array}{l}\text { The contracts do not define how the volume percent } \\
\text { insoluble solids will be measured. } \\
\text { During the process test, the quantity of solids for various } \\
\text { WTC dilutions will be measured over the temperature } \\
\text { range of } 25 \text { to } 65^{\circ} \mathrm{C} \text {. }\end{array}$ & $\begin{array}{l}\text { Insoluble solids } \\
\text { measurement } \\
\text { (See Table 4, } \\
\text { Item \# 21). }\end{array}$ \\
\hline
\end{tabular}

${ }^{1}$ These point estimates were based on a thermodynamic model (ESP) that was used to estimate the liquid phase composition of the waste. 
Table 3. Alternative Case 2 Operating Scenario Evaluation. (9 Sheets)

\begin{tabular}{|c|c|c|c|}
\hline Elements $^{\mathrm{a}}$ & Requirements $^{b}$ & Discussion/evaluation & $\begin{array}{l}\text { Information } \\
\text { needs }\end{array}$ \\
\hline $\begin{array}{l}\text { Element } 4 \text { - Part } \\
\text { 1: Envelope } \\
\text { Requirements } \\
\text { (continued) }\end{array}$ & $\begin{array}{l}\text { Operating Specifications } \\
\text { from OSD-T-151-00007 } \\
\text { (DOE-RL 1996, Section C. } 6 \\
\text { invokes the OSD by } \\
\text { reference). } \\
\text { See Section } 2.0 \text {, Table } 3 \text { (of } \\
\text { main report). }\end{array}$ & $\begin{array}{l}\text { The contract does not explicitly state which specifications } \\
\text { from the OSD apply to the waste. The PHMC assumes } \\
\text { that the Tank Composition ( } 7.2 .1 \text { ) and Heat Generation } \\
\text { Rate (7.2.8) limits apply to the waste. These limits are } \\
\text { shown in Section } 2.0 \text { (Table } 3 \text { ) of main report. } \\
\text { The TWRSO\&UP (Kirkbride et al. 1997, Section } \\
3.1 .1 .6 \text { ) compared the point estimates of the composition } \\
\text { of the waste as staged in } 241-\mathrm{AP}-102 \text { and -104 with the } \\
\text { Tank Composition (Tank Corrosion) specifications. All } \\
\text { limits were satisfied for Batch } 10 \text {. Uncertainty is not an } \\
\text { issue since the [OH], [NO } 2 \text { ] and [NO } 3 \text { in the staging } \\
\text { tanks can be adjusted if needed before the feed } \\
\text { qualification samples are taken. } \\
\text { The TWRSO\&UP (Section } 3.1 .1 .6 \text { ) also evaluated the } \\
\text { heat generation rate rule and found that all limits were } \\
\text { satisfied for Batch } 10 \text {, decayed to the estimated time of } \\
\text { delivery. The estimated heat generation rate for Batch } 10 \\
\text { is approximately } 5,500 \mathrm{BTU} / \mathrm{hr} \text {. This is well within the } \\
\text { maximum limit of } 70,000 \mathrm{BTU} / \mathrm{hr} \text {. } \\
\text { Conformance with OSD factors is achieved for all known } \\
\text { factors. }\end{array}$ & $\begin{array}{l}\text { During the } \\
\text { process testing, } \\
\text { full analysis is } \\
\text { needed for } \\
\text { Envelopes A and } \\
\text { C, including } \\
137 \text { Cs (See Table } \\
4 \text {, Item \# 22). }\end{array}$ \\
\hline
\end{tabular}


Table 3. Alternative Case 2 Operating Scenario Evaluation. (9 Sheets)

\begin{tabular}{|c|c|c|c|}
\hline Elements $^{\mathrm{a}}$ & Requirements ${ }^{b}$ & Discussion/evaluation & $\begin{array}{l}\text { Information } \\
\text { needs }\end{array}$ \\
\hline \multirow[t]{2}{*}{$\begin{array}{l}\text { Element 4 - Part } \\
\text { 2: Quantity } \\
\text { Requirements }\end{array}$} & $\begin{array}{l}\text { Maximum }{ }^{137} \mathrm{Cs} \\
\text { concentration of } 5.86 \mathrm{E} 10 \\
\mathrm{~Bq} / \text { liter }(6 \mathrm{Ci} / \mathrm{gal}) \\
\\
\text { Maximum }{ }^{90} \mathrm{Sr} \text { concentration } \\
\text { of } 4.04 \mathrm{E} 5 \mu \mathrm{Ci} / \mathrm{L} \text {. }\end{array}$ & $\begin{array}{l}\text { This limit is equivalent to } 1.59 \mathrm{E} 6 \mu \mathrm{Ci} / \mathrm{L} \text {. The OSD limit } \\
\text { of } 5.74 \mathrm{E} 5 \mu \mathrm{Ci} / \mathrm{L} \text { is more restrictive. } \\
\text { The tank characterization report estimates the }{ }^{137} \mathrm{Cs} \\
\text { concentration of } 342 \mu \mathrm{Ci} / \mathrm{g} \text { (Herting et al. } 1995 \text { ). } \\
\text { Clearly, the }{ }^{137} \mathrm{Cs} \text { concentration will be well below the } \\
\text { limit for this waste. } \\
\text { The tank characterization report estimates the }{ }^{90} \mathrm{Sr} \\
\text { concentration in } 241-\mathrm{SY}-101 \text { (Herting et. al. } 1995 \text { ) to be } \\
19.3 \mu \mathrm{Ci} / \mathrm{L} \text {. Clearly, the }{ }^{90} \mathrm{Sr} \text { concentration is well } \\
\text { below the limit for this waste. } \\
\text { Conformance with OSD factors is achieved. }\end{array}$ & $\begin{array}{l}\text { Samples should } \\
\text { be analyzed } \\
\text { during process } \\
\text { testing, but all } \\
\text { indications are } \\
\text { that the levels of } \\
{ }^{137} \mathrm{Cs} \text { and }{ }^{90} \mathrm{Sr} \\
\text { are well below } \\
\text { the applicable } \\
\text { limits (See Table } \\
4 \text {, Item \# 22). }\end{array}$ \\
\hline & $\begin{array}{l}\text { The PHMC assumed } \\
\text { minimum limits to } \\
\text { distinguish between } \\
\text { Envelope } \mathrm{A} \text { and } \mathrm{C} \text { and } \\
\text { between Envelopes } \mathrm{A} \text { and } \mathrm{B} \text {. }\end{array}$ & $\begin{array}{l}\text { The discriminators for Envelopes } \mathrm{A} \text { and } \mathrm{C} \text { are } \mathrm{SO}_{4} \text {, } \\
\text { TOC, TRU, and }{ }^{90} \mathrm{Sr} \text {. }\end{array}$ & $\begin{array}{l}\text { Determine } \mathrm{SO}_{4} \text {, } \\
\mathrm{TOC}, \mathrm{TRU} \text {, and } \\
{ }^{90} \mathrm{Sr} \\
\text { concentrations } \\
\text { (See Table } 4 \text {, } \\
\text { Item \# 22). }\end{array}$ \\
\hline
\end{tabular}


Table 3. Alternative Case 2 Operating Scenario Evaluation. (9 Sheets)

\begin{tabular}{|c|c|c|c|}
\hline Elements $^{\mathrm{a}}$ & Requirements $^{\mathrm{b}}$ & Discussion/evaluation & $\begin{array}{c}\text { Information } \\
\text { needs }\end{array}$ \\
\hline $\begin{array}{l}\text { Element } 4 \text { - Part } \\
\text { 2: Quantity } \\
\text { Requirements } \\
\text { (continued) }\end{array}$ & $\begin{array}{l}\text { Batch size (mass of sodium) } \\
\text { constraints (from the } \\
\text { contracts) } \geq 100 \mathrm{MT} \text { Na. } \\
\text { PHMC targeted batch size } \\
\text { range (from the ICD (PHMC } \\
\text { 1997, Table 3D): } 100-600 \\
\text { MT Na. } \\
\text { PHMC desired batch } 10 \text { size } \\
\text { (from Operating Scenario): } \\
\text { 1,230 MT Na (Kirkbride et } \\
\text { al. 1997, Table 3.1-5) }\end{array}$ & $\begin{array}{l}\text { During process testing, the amount of recoverable } \mathrm{Na} \\
\text { should be measured. The TCR puts the inventory of } \mathrm{Na} \\
\text { at } 1.38 \mathrm{E}+\mathrm{E} 6 \mathrm{~kg} \text {. Note that some } 241-\mathrm{SY}-101 \text { waste is } \\
\text { planned for Batch } 11 \text { as well. }\end{array}$ & $\begin{array}{l}\text { Determine } \mathrm{Na} \\
\text { quantity (See } \\
\text { Table } 4 \text {, } \\
\text { Item \# 22). }\end{array}$ \\
\hline \multirow[t]{4}{*}{$\begin{array}{l}\text { Element } 5 \text { - } \\
\text { Miscellaneous } \\
\text { Inputs }\end{array}$} & $\begin{array}{l}\text { Physical form of Tank } \mathrm{T} \\
\text { contents }\end{array}$ & $\begin{array}{l}\text { From Herting et al. (1995): 241-SY-101 has a crust layer } \\
\text { of } 0.54 \mathrm{~m}(1.76 \mathrm{ft}) \text {. The convective layer is } \\
\text { approximately } 5.61 \mathrm{~m}(18.4 \mathrm{ft}) \text {, and the non-convective } \\
\text { layer is approximately } 4.08 \mathrm{~m}(13.4 \mathrm{ft}) \text {. }\end{array}$ & $\begin{array}{l}\text { No further } \\
\text { information is } \\
\text { needed }\end{array}$ \\
\hline & $\begin{array}{l}\text { Heel from prior batch } \\
\text { remaining in staging tanks }\end{array}$ & $\begin{array}{l}\text { 10-in. supernate heels and sludge remaining in } \\
241-\mathrm{SY}-102 \text { need to be addressed. Heels remaining in } \\
\text { East Area staging tanks may also need to be addressed. }\end{array}$ & $\begin{array}{l}\text { None, process } \\
\text { test needed (See } \\
\text { Table 4, } \\
\text { Item \# 11). }\end{array}$ \\
\hline & Shimming Batch 10 & No shimming is anticipated. & $\begin{array}{l}\text { No further } \\
\text { information is } \\
\text { needed }\end{array}$ \\
\hline & RL direction & $\begin{array}{l}\text { No changes to applicable M\&I ICD requirements have } \\
\text { been made to date. }\end{array}$ & $\begin{array}{l}\text { No further } \\
\text { information is } \\
\text { needed }\end{array}$ \\
\hline
\end{tabular}

${ }^{\mathrm{a}}$ Elements are taken from the Decision Rule statement in Section 6.1 of PSDQO-01.

${ }^{b}$ Requirements are taken from Sections 4.1, 4.2, 4.3, 4.4, and 4.5 of PSDQO-01. 
Table 4 was developed jointly by TWRS Characterization and Tank Waste Retrieval. It is intended to show what information is still needed, what can be obtained by calculations with existing data, what requires new (or existing) samples, analysis and/or process testing. Where samples are required, the amount and "representativeness" of the sample will be stated. Where analysis is needed, the specific analytes and QA requirements will be stated. If process testing is needed, the amount of sample and goals of the process test will be stated. Appropriate level of end description of QA requirements will be covered in the specific work plan for these limited process tests.

Table 4. Information Needs. (3 Sheets)

\begin{tabular}{|c|c|c|c|}
\hline Item & Information need & $\begin{array}{l}\text { Planned resolution } \\
\end{array}$ & Sample required \\
\hline 1 & $\begin{array}{l}\text { Desired dilution } \\
\text { ratio and diluent } \\
\text { composition }\end{array}$ & $\begin{array}{l}\text { Perform lab test: measure minimum dilution } \\
\text { ratio which satisfies all transfer system; } \\
\text { measure maximum dilution ratio where } \\
\text { gibbsite will not become a problem. } \\
\text { Determine desired dilution ratio and diluent. }\end{array}$ & $\begin{array}{l}300 \mathrm{ml} \mathrm{SY}-101 \\
\text { WTC. }\end{array}$ \\
\hline 2 & $\begin{array}{l}\text { Confirm a dilution } \\
\text { ratio of } 50 \% \text { for the } \\
\text { TCS and blend is } \\
\text { below saturation in } \\
\text { major Na salts }\end{array}$ & $\begin{array}{l}\text { Perform lab test: to confirm that the as } \\
\text { retrieved waste remain below saturation in } \\
\text { major Na salts during the transfer to the } \\
\text { staging tanks }\end{array}$ & $\begin{array}{l}\text { None, sample } \\
\text { from Item } 1 \text { can } \\
\text { be used. }\end{array}$ \\
\hline 3 & $\begin{array}{l}\text { Determine } \\
\text { viscosity, } \mathrm{SpG}, \\
\text { suspended solids }\end{array}$ & $\begin{array}{l}\text { Perform lab test to determine viscosity, SpG, } \\
\text { suspended solids }\end{array}$ & $\begin{array}{l}300 \mathrm{ml} \mathrm{SY-101} \\
\text { WTC. }\end{array}$ \\
\hline 4 & $\begin{array}{l}\text { Determine solid } \\
\text { formation, if any }\end{array}$ & $\begin{array}{l}\text { An extended storage of supernate sub- } \\
\text { samples from the Tank Supernate Composite } \\
\text { (TSC) dilution test at dilution ratio up to } \\
120 \% \text {. }\end{array}$ & $\begin{array}{l}\text { None, sample } \\
\text { from Item } 3 \text { can } \\
\text { be used. }\end{array}$ \\
\hline 5 & $\begin{array}{l}\text { Chemical and } \\
\text { radionuclide } \\
\text { analyses. }\end{array}$ & $\begin{array}{l}\text { Measure the analytes in Section 2.0, Tables } 1 \\
\text { and } 2 \text { (in main report) (Envelope C analytes). } \\
\text { Determine the bulk supernate composition. }\end{array}$ & $\begin{array}{l}\text { None, sample } \\
\text { from Item } 1 \text { can } \\
\text { be used. }\end{array}$ \\
\hline 6 & {$[\mathrm{Na}]$ measurement } & $\begin{array}{l}\text { Measurement of }[\mathrm{Na}] \text { can be obtained from } \\
\text { item \#5. }\end{array}$ & None. \\
\hline 7 & $\begin{array}{l}\text { Confirm insoluble } \\
\text { solids fraction limit } \\
\text { will not exceed } 5 \\
\text { volume \%. }\end{array}$ & $\begin{array}{l}\text { Measurement of solid in the blend. This data } \\
\text { will be obtained during Item } 1 \text { testing. }\end{array}$ & None. \\
\hline 8 & $\begin{array}{l}\text { Operating } \\
\text { Specification } \\
\text { requirements }\end{array}$ & $\begin{array}{l}\text { Perform lab test; Analysis of chemical and } \\
\text { radionuclides can be obtained by results from } \\
\text { item \#5. }\end{array}$ & None \\
\hline
\end{tabular}


HNF-2799

Revision 0

Table 4. Information Needs. (3 Sheets)

\begin{tabular}{|c|c|c|c|}
\hline Item & Information need & Planned resolution & Sample required \\
\hline 9 & $\begin{array}{l}\text { Determine sulfate } \\
\text { concentration as a } \\
\text { discriminator for } \\
\text { Envelope C. }\end{array}$ & $\begin{array}{l}\text { Perform lab test; Analysis of sulfate can be } \\
\text { obtained by results from item } \# 5 \text {. }\end{array}$ & None \\
\hline 10 & $\begin{array}{l}\text { Determination of } \\
\mathrm{Na} \text { quantity }\end{array}$ & $\begin{array}{l}\text { Perform lab test; Analysis of } \mathrm{Na} \text { can be } \\
\text { obtained by results from item } \# 5 \text {. }\end{array}$ & None \\
\hline 11 & $\begin{array}{l}\text { Determine the } \\
\text { Chemical and } \\
\text { radionuclide } \\
\text { analyses of heel in } \\
241-S Y-102 \text {. }\end{array}$ & $\begin{array}{l}\text { Perform lab test; Analysis of chemical and } \\
\text { radionuclides. }\end{array}$ & $\begin{array}{l}100 \mathrm{ml} \text { of } \\
\text { SY-102 heel. }\end{array}$ \\
\hline 12 & $\begin{array}{l}\text { Desired dilution } \\
\text { ratio and diluent } \\
\text { composition for a } \\
\text { representative } \\
\text { sample of supernate } \\
\text { and salt slurry. }\end{array}$ & $\begin{array}{l}\text { Perform lab test: measure minimum dilution } \\
\text { ratio which satisfies all transfer system; } \\
\text { measure maximum dilution ratio where } \\
\text { gibbsite will not become a problem. } \\
\text { Determine desired dilution ratio and diluent. }\end{array}$ & $\begin{array}{l}300 \mathrm{ml} \mathrm{SY}-101 \\
\text { Tank Supernate } \\
\text { Composite } \\
\text { (TSC). } 300 \mathrm{ml} \\
\text { SY-101 tank } \\
\text { saltcake } \\
\text { composite } \\
\text { (TSCC) }\end{array}$ \\
\hline 13 & $\begin{array}{l}\text { Confirm as- } \\
\text { retrieved waste } \\
\text { remains below satn } \\
\text { in major NA salts } \\
\text { during transfer. }\end{array}$ & $\begin{array}{l}\text { Perform lab test: to confirm that the as } \\
\text { retrieved waste remain below saturation in } \\
\text { major Na salts during the transfer to the } \\
\text { staging tanks. Will be determined in Item } \\
12 \text {. }\end{array}$ & None. \\
\hline 14 & $\begin{array}{l}\text { Confirm as- } \\
\text { retrieved waste } \\
\text { remains }<10 \mathrm{cP} \text {, } \\
<1.5 \mathrm{SpG} \text {, and } \\
<30 \% \text { solids } \\
\text { during transfer. }\end{array}$ & $\begin{array}{l}\text { Perform lab test to determine viscosity, SpG, } \\
\text { suspended solids. Use sample from Item } 12 \text {. }\end{array}$ & None. \\
\hline 15 & $\begin{array}{l}\text { Determine solid } \\
\text { formation and solid } \\
\text { settling time, if } \\
\text { any. }\end{array}$ & $\begin{array}{l}\text { An extended storage of supernate sub- } \\
\text { samples from the TSC dilution test at dilution } \\
\text { ratio up to } 120 \% \text {. Use sample from Item } 12\end{array}$ & None. \\
\hline 16 & $\begin{array}{l}\text { Chemical and } \\
\text { radionuclide } \\
\text { analyses }\end{array}$ & $\begin{array}{l}\text { Measure the analytes in Section } 2.0 \text { (Tables } 1 \\
\text { and } 2 \text { ) of main report (Envelope } C \text { analytes). } \\
\text { Determine the bulk supernate and diluted salt } \\
\text { slurry composition. }\end{array}$ & None. \\
\hline 17 & {$[\mathrm{Na}]$ measurement } & $\begin{array}{l}\text { Measurement of Na can be obtained from } \\
\text { item \# } 16 .\end{array}$ & None \\
\hline
\end{tabular}


HNF-2799

Revision 0

Table 4. Information Needs. (3 Sheets)

\begin{tabular}{|l|l|l|l|}
\hline Item & Information need & \multicolumn{1}{|c|}{ Planned resolution } & Sample required \\
\hline 18 & $\begin{array}{l}\text { Operating } \\
\text { Specification } \\
\text { requirements }\end{array}$ & $\begin{array}{l}\text { Perform lab test; Analysis of chemical and } \\
\text { radionuclides can be obtained by results from } \\
\text { item \#16. }\end{array}$ & None. \\
\hline 19 & $\begin{array}{l}\text { Determine percent } \\
\text { solids at various } \\
\text { dilutions and } \\
\text { temperatures as a } \\
\text { function of time } \\
\text { while mixing. }\end{array}$ & $\begin{array}{l}\text { Perform lab test on mixed diluted SY-101 } \\
\text { and SY-103 waste. }\end{array}$ & $\begin{array}{l}\text { 150 ml diluted } \\
\text { SY-101 WTC } \\
\text { and 150 ml } \\
\text { diluted SY-103 } \\
\text { WTC. }\end{array}$ \\
\hline 20 & $\begin{array}{l}\text { Confirm } \\
\text { compatibility with } \\
\text { SY-101 }\end{array}$ & $\begin{array}{l}\text { Perform process test; Mix diluted SY-101 } \\
\text { with SY-103 WTC. During the lab test in } \\
\text { Item \# 19 confirm compatibility. }\end{array}$ & None. \\
\hline 21 & $\begin{array}{l}\text { Determine settling } \\
\text { times. }\end{array}$ & $\begin{array}{l}\text { During the lab test in Item \# 19 confirm } \\
\text { compatibility. }\end{array}$ & None. \\
\hline 22 & $\begin{array}{l}\text { Determine the } \\
\text { Chemical and } \\
\text { radionuclide } \\
\text { analyses of dilute } \\
\text { mixture of SY-101 } \\
\text { and SY-103. }\end{array}$ & $\begin{array}{l}\text { Measure the analytes in Section 2.0 (Tables 1 } \\
\text { and 2) of main report (Envelope C analytes). } \\
\text { Determine the bulk supernate and diluted salt } \\
\text { slurry composition. Waste from Item 19 } \\
\text { should be used. }\end{array}$ & None. \\
\hline
\end{tabular}

There are 22 items that have been flagged in Tables 1,2 , and 3 requiring further information. All items will be addressed by a specific process test with specific material from 241-SY-101. There are no other information needs requiring either an analysis of an existing 241-SY-101 sample or the collection of additional sample followed by analysis in order to confirm that tank 241-SY-101 is appropriate for Batch 10. 
HNF-2799

Revision 0

\subsection{REFERENCES}

Boston, H. L., 1997, Subcontract Number 80232764-9-K001, Design Basis for Retrieval Equipment in Tanks $A N-104$ and $A N-105$, Letter to A. M. Umek (Fluor Daniel Hanford, Incorporated), LMHC-9758071, Lockheed Martin Hanford Corporation, Richland, Washington.

Certa, P. J., and J. Jo, 1998, Data Quality Objectives for TWRS Privatization Phase: 1 confirm Tank $T$ is an Appropriate Feed Source for Low-Activity Waste Feed Batch X, HNF-1796, Rev. 1, Numatec Hanford Corporation, Richland, Washington.

DOE-RL, 1996, TWRS Privatization, Contract Numbers DE-RP06-96RL13308 and 13309, U.S. Department of Energy, Richland, Washington.

Garfield, J. S., 1997, Tank 241-AN-104 Dilution/Dissolution Test Requirements, internal memo to DL Herting, 8C451-97-004 (March 27), Numatec Hanford Corporation, Richland, Washington.

Herting, D. L., L. C. Amato, and A. T. Dicenso, 1995, Tank Characterization Report for Double-Shell Tank 241-SY-101, WHC-SD-WM-ER-409, Rev. 0, Westinghouse Hanford Company, Richland, Washington.

Kirkbride, R. A., G. K. Allen, P. J. Certa, A. F. Manuel, R. M. Orme, L. W. Shelton, E. J. Slaathaug, R. S. Wittman, G. T. MacLean and D. L. Penwell, 1997, Tank Waste Remediation System Operation and Utilization Plan, HNF-SD-WM-SP-012, Rev. 0A, Vol I and II, Numatec Hanford Corporation, Richland, Washington.

PHMC, 1996, Unclassified Operating Specification for the 24l-AN, AP, AW, AY, AZ, and SY Tank Farms, OSD-T-151-00007, Rev. H-18, Fluor Daniel Hanford, Richland, Washington.

PHMC, 1997, Interface Control Document Between DOE and the PHMC, Low-Activity Waste Feed, HNF-SP-1223 (ICD-19), Project Hanford Management Contractor, Richland, Washington. 
HNF-2799

Revision 0

This page intentionally left blank. 


\section{ADDENDUM 9}

\section{APPLICATION OF}

\section{"CONFIRM TANK T IS AN APPROPRIATE FEED SOURCE \\ FOR LOW-ACTIVITY WASTE FEED BATCH 11"}

TO

241-SY-103 / BATCH 11 
HNF-2799

Revision 0

This page intentionally left blank.

Addendum 9-2 
HNF-2799

Revision 0

CONTENTS

1.0 INTRODUCTION

Addendum 9-5

2.0 EVALUATION

2.1 BASE CASE OPERATING SCENARIO

Addendum 9-5

2.2 ALTERNATIVE CASE 1 OPERATING SCENARIO

Addendum 9-5

2.3 ALTERNATIVE CASE 2 OPERATING SCENARIO

Addendum 9-7

Addendum 9-8

3.0 REFERENCES

Addendum 9-28

\section{LIST OF TABLES}

1. Base Case Operating Scenario Evaluation. . . . . . . . . . . . . Addendum 9-10

2. Alternative Case 1 Operating Scenario Evaluation . . . . . . . . Addendum 9-16

3. Alternative Case 2 Operating Scenario Evaluation . . . . . . . . . Addendum 9-19

4. Information Needs . . . . . . . . . . . . . . . . . A Addendum $9-25$ 
HNF-2799

Revision 0

\section{LIST OF TERMS}

DOE U.S. Department of Energy

DQO Data quality objective

ICD Interface Control Document

LAW Low-Activity Waste

M Molar (gmoles/liter)

PHMC Project Hanford Management Contract(or)

PMBS Project Master Baseline Schedule

PSDQO Problem-Specific Data Quality Objectives

RL U.S. Department of Energy-Richland Operations

TANK T Refers to the contents from one tank, multiple tanks, or portions of one or more tanks that will be used to prepare a feed batch

TOC Total Organic Carbon

TSC Tank Supernate Composite

TWRS Tank Waste Remediation System

TWRSO\&UP Tank Waste Remediation System Operation and Utilization Plan

WTC Whole tank composite 
HNF-2799

Revision 0

\section{ADDENDUM 9}

\section{APPLICATION OF "CONFIRM TANK T IS AN APPROPRIATE FEED SOURCE FOR LOW-ACTIVITY WASTE FEED BATCH " TO 241-SY-103 / BATCH 11}

\subsection{INTRODUCTION}

This addendum applies Revision 1 of "Confirm Tank $\mathrm{T}$ is an Appropriate Feed Source for Low-Activity Waste Feed Batch 11" problem-specific data quality objectives (PSDQO) to tank 241-SY-103 / Batch 11.

This application of the data quality objective (DQO) is divided into a Base Case Operating Scenario and two alternative case operating scenarios. The Base Case homogenizes the waste in tank 241-SY-103 by mixing prior to transfer to tank 241-SY-102. Alternative Case 1 transfers supernate from tank 241-SY-103 without mixing followed by diluent addition, mixing, and settling of any remaining solids prior to transfer to tank 241-SY-102. Alternative Case 2 involves mixing the waste from tank 241-SY-103 with waste from tank 241-SY-101 in tank 241-SY-102. The waste from each tank would be a well-mixed, and diluted to allow transfer within operational limits. In all three cases, compatibility with the transuranic solids in tank 241-SY-102 must be evaluated.

\subsection{EVALUATION}

\subsection{BASE CASE OPERATING SCENARIO}

Translate the operating scenario into a series of process steps.

The base case operating scenario from the Tank Waste Remediation System Operation and Utilization Plan (TWRSO\&UP) (Kirkbride et al. 1997) includes the following steps to make up Batch 11:

- Empty supernate from 241-SY-102, leaving a 0.1-ML (10-in.) layer of supernate over the residual sludge layer. The supernate will be transferred cross-site into either tank 241-AN-102 or 241-AN-107 for eventual processing in 200 East Area.

- Homogenize the waste in 241-SY-103 using mixer pumps to resuspend the salt slurry.

- Transfer the homogenized waste in 241-SY-103 to 241-SY-102 until the receiver 
tank is full. During the transfer, the proper amount of diluent will be added to the waste at the transfer pump inlet.

- Repeat the above three steps as necessary until tank 241-SY-103 has been emptied.

Compatibility of the waste with the residual liquid in 241-SY-102 may need to be evaluated for the first transfer from 241-SY-103. Compatibility of 241-SY-103 waste with the transuranic sludge in 241-SY-102 is extremely important to ensure that envelope limits are not exceeded.

Define the waste that applies to each element in the decision rule.

Element 1, Dilution Ratio and Diluent Composition: this applies to the whole tank composite (WTC) over the temperature range of 25 to $65^{\circ} \mathrm{C}$.

Element 2, Transfer Requirements: There are several nearly identical transfers. They will be treated as one transfer. Transfer requirements apply to a whole tank composite of the waste currently in 241-SY-103 after addition of the proper amount of diluent over the temperature range of 25 to $65^{\circ} \mathrm{C}$.

Element 3, Mixing Requirements: The first transfer will involve mixing with the liquid waste residual over the sludge in 241-SY-102. Subsequent transfers will involve mixing of the WTC with the residual concentrated waste from the previous transfer over the sludge in 241-SY-102. Two sets of mixing requirements apply. The first mixing requirement apply to blend of the diluted WTC for 241-SY-103 with the initial supernate layer and the sludge in 241-SY-102 over the temperature range of 25 to $65^{\circ} \mathrm{C}$. After the first transfer, the residual supernate is assumed to be the diluted WTC from 241-SY-101. Therefore the second mixing requirement applies to the diluted WTC for 241-SY-103 and the sludge in 241-SY-102 over the temperature range of 25 to $65^{\circ} \mathrm{C}$.

Element 4, Envelope and Quantity Requirements: the ultimate composition of Batch 11 will depend somewhat upon the residual supernate in 241-SY-102 and on any reactions between the sludge in 241-SY-102 and the WTC from 241-SY-103. The two composites from the mixing study above should be analyzed and evaluated against the Envelope $\mathrm{A}$ and $\mathrm{C}$ limits.

Element 5, Miscellaneous Inputs: These inputs apply to the WTC of 241-SY-103 or to changes in the operating scenario that may be imposed in the future.

Evaluate existing data and determine information needs.

Table 1 contains the evaluation of the base case operating scenario for all the elements of the decision rules found in Section 6 of the PSDQO (Certa and Jo 1998). The table lists each element taken from Section 4.0 of the PSDQO. For each element, the requirements specific to 
HNF-2799

Revision 0

241-SY-103 Batch 11 are listed. Each requirement is evaluated against existing data and the remaining information needs are identified. The information needs are summarized in Table 4.

\subsection{ALTERNATIVE CASE 1 OPERATING SCENARIO}

Translate the operating scenario into a series of process steps.

The TWRSO\&UP (Kirkbride et al. 1997) recommended that process control issues be taken into account. This alternative case operating scenario was developed based on consideration of process control issues and is currently being evaluated and incorporated into the project master baseline schedule and corresponding logic diagrams. The steps that directly affect the composition of Batch 11 are listed below:

- Empty supernate from 241-SY-102, leaving a 0.1-ML (10-in.) layer of supernate over the residual sludge layer. The supernate will be transferred cross-site into either tank $241-\mathrm{AN}-102$ or 241 -AN-107 for eventual processing in 200 East Area.

- Decant supernate from tank 241-SY-103 to 241-SY-102. During the transfer, the proper amount of diluent will be added to the waste at the transfer pump inlet.

- Repeat the above two steps until all supernate has been pumped from 241-SY-103.

- Add diluent to the salt slurry in 241-SY-103 and mix.

- Allow undissolved solids to settle in 241-SY-103.

- Transfer the liquid to 241-SY-102, leaving a 10-in heel in 241-SY-103. No additional diluent is expected to be needed for the transfer. It may be necessary to periodically transfer waste cross-site from 241-SY-102 to create space for the transfer.

Compatibility of the waste with the residual liquid in 241-SY-102 may need to be evaluated for the first transfer from 241-SY-103. Compatibility of 241-SY-103 waste with the transuranic sludge in 241-SY-102 is extremely important to ensure that envelope limits are not exceeded.

Define the waste that applies to each element in the decision rule.

Element 1, Dilution Ratio and Diluent Composition: this applies to the supernate composite and salt slurry composite of 241-SY-103 over the temperature range of 25 to $65^{\circ} \mathrm{C}$.

Element 2, Transfer Requirements: There are two types of transfers, supernate and salt slurry. The transfers should be evaluated over the temperature range of 25 to $65^{\circ} \mathrm{C}$. 
Element 3, Mixing Requirements: Two mixing scenarios must be evaluated. The first is the mixing of supernate with the liquid and the sludge remaining in 241-SY-102. The second is the mixing of diluted salt slurry with the sludge in 241-SY-102. Mixing studies should be carried out over the temperature range of 25 to $65^{\circ} \mathrm{C}$.

Element 4, Envelope and Quantity Requirements: the ultimate composition of Batch 11 will depend somewhat upon the residual supernate in 241-SY-102 and on any reactions between the sludge in 241-SY-102 and the WTC from 241-SY-103. The two composites from the mixing study above should be analyzed and evaluated against the Envelope $\mathrm{A}$ and $\mathrm{C}$ limits.

Element 5, Miscellaneous Inputs: These inputs apply to the supernate and salt slurry composites for $241-\mathrm{SY}-103$ or to changes in the operating scenario that may be imposed in the future.

Table 2 contains the evaluation of the alternative case 1 operating scenario for all the elements of the decision rules found in Section 6 of the PSDQO (Certa and Jo). The table lists each element taken from Section 4.0 of the PSDQO (Certa and Jo). For each element, the requirements specific to 241-SY-103/Batch 11 are listed. Each requirement is evaluated against existing data and the remaining information needs are identified. The information needs are summarized in Table 4.

\subsection{ALTERNATIVE CASE 2 OPERATING SCENARIO}

Translate the operating scenario into a series of process steps.

The TWRSO\&UP (Kirkbride et al. 1997) recommended that process control issues be taken into account. This alternative case operating scenario was developed based on consideration of process control issues and is currently being evaluated and incorporated into the project master baseline schedule and corresponding logic diagrams. The steps that directly affect the composition of Batch 11 are listed below:

- Homogenized, diluted waste from 241-SY-101 is assumed to reside in 241-SY-102. The volume of this waste is not known.

- Homogenize the waste in 241-SY-103 using mixer pumps to resuspend the salt slurry.

- Transfer the homogenized waste in 241-SY-103 to 241-SY-102 until the receiver tank is full. During the transfer, the proper amount of diluent will be added to the waste at the transfer pump inlet.

- Pump the mixture of supernate waste from 241-SY-102 cross-site to 241-AN-102 or 241-AN-107, leaving a $0.1-\mathrm{ML}(10$-in) heel of supernate over the sludge in 241-SY-102. 
- Resume transferring homogenized waste from 241-SY-103 to 241-SY-102, adding the proper amount of diluent at the pump inlet.

- Repeat the above two steps until tank 241-SY-103 is emptied.

Compatibility of the waste with the waste from 241-SY-101 may need to be evaluated for the first transfer from 241-SY-103. Compatibility of 241-SY-103 waste with the transuranic sludge in 241-SY-102 is extremely important to ensure that envelope limits are not exceeded.

Define the waste that applies to each element in the decision rule.

Element 1, Dilution Ratio and Diluent Composition: this applies to the WTC of 241-SY-103 over the temperature range of 25 to $65^{\circ} \mathrm{C}$.

Element 2, Transfer Requirements: Two transfers need to be evaluated. The first is the transfer of the WTC of the waste in 241-SY-103 to 241-SY-102 when it is partially filled with waste from 241-SY-101. The second is the transfer of the WTC of the waste in 241-SY-103 to 241-SY-102 when it contains a small heel of waste over sludge. The heel is assumed to be the same as the WTC of 241-SY-103. The transfers should be evaluated after addition of the proper amount of diluent over the temperature range of 25 to $65^{\circ} \mathrm{C}$.

Element 3, Mixing Requirements: The two transfer scenarios need to be evaluated while mixing with the sludge in $241-\mathrm{SY}-102$ over the temperature range of 25 to $65^{\circ} \mathrm{C}$.

Element 4, Envelope and Quantity Requirements: the ultimate composition of Batch 11 will depend somewhat upon the residual supernate in 241-SY-102 and on any reactions between the sludge in 241-SY-102 and the WTC from 241-SY-103. The two composites from the mixing study above should be analyzed and evaluated against the Envelope $\mathrm{A}$ and $\mathrm{C}$ limits.

Element 5, Miscellaneous Inputs: These inputs apply to the WTC of 241-SY-103 or to changes in the operating scenario that may be imposed in the future.

Evaluate existing data and determine information needs.

Table 3 contains the evaluation of the alternative case 2 operating scenario for all the elements of the decision rules found in Section 6 of the PSDQO (Certa and Jo). The table lists each element taken from Section 4.0 of the PSDQO (Certa and Jo). For each element, the requirements specific to 241-SY-103/Batch 11 are listed. Each requirement is evaluated against existing data and the remaining information needs are identified. The information needs are summarized in Table 4. 
Table 1. Base Case Operating Scenario Evaluation. (8 Sheets)

\begin{tabular}{|c|c|c|c|}
\hline Elements $^{\mathrm{a}}$ & Requirements $^{b}$ & Discussion/evaluation & $\begin{array}{l}\text { Information } \\
\text { needs }\end{array}$ \\
\hline $\begin{array}{l}\text { Element } 1, \\
\text { Dilution Ratio } \\
\text { and Diluent } \\
\text { Composition }\end{array}$ & $\begin{array}{l}\text { Determine the desired } \\
\text { dilution ratio and diluent } \\
\text { composition for each waste } \\
\text { transfer. }\end{array}$ & $\begin{array}{l}\text { A test plan, based on instruction provided by the } \\
\text { Disposal Program (e.g. Garfield 1997), is need for } \\
\text { process testing. The plan will obtain the following } \\
\text { information for the } 241-\mathrm{SY}-103 \mathrm{WTC} \text {. Required } \\
\text { dilution ratio to prevent precipitation over the } \\
\text { temperature range of } 25^{\circ} \mathrm{C} \text { to } 65^{\circ} \mathrm{C} \text {. } \\
\text { Dilution ratio and diluent composition will be } \\
\text { established. }\end{array}$ & $\begin{array}{l}\text { Desired dilution } \\
\text { ratio and diluent } \\
\text { composition (See } \\
\text { Table 4, Item 1). }\end{array}$ \\
\hline \multirow[t]{2}{*}{$\begin{array}{l}\text { Element } 2 \text {, } \\
\text { Transfer } \\
\text { Requirements }\end{array}$} & $\begin{array}{l}\text { Confirm that the as-retrieved } \\
\text { waste (including dilution } \\
\text { water or caustic) remains } \\
\text { below saturation in major } \mathrm{Na} \\
\text { salts during the transfer to } \\
\text { the staging tank. }\end{array}$ & $\begin{array}{l}\text { A process test is needed to confirm that the } \\
\text { as-retrieved waste (including dilution water or caustic) } \\
\text { remains below saturation in major } \mathrm{Na} \text { salts during the } \\
\text { transfer to the staging tank. }\end{array}$ & $\begin{array}{l}\text { Confirm that the } \\
\text { diluted WTC is } \\
\text { below saturation } \\
\text { in major Na salts } \\
\text { (See Table 4, } \\
\text { Item 2). }\end{array}$ \\
\hline & $\begin{array}{l}\text { Confirm that the as-retrieved } \\
\text { waste (including dilution } \\
\text { water or caustic) remain at or } \\
\text { below viscosity of } 10 \mathrm{cP} \text {, at } \\
\text { or below a } 1.5 \mathrm{SpG} \text {, and at } \\
\text { or below } 30 \text { percent solids by } \\
\text { volume during the transfer to } \\
\text { the staging tank. }\end{array}$ & $\begin{array}{l}\text { A process test is needed. The test will determine } \\
\text { viscosity, density, and quantity of settled solids for } \\
\text { the undiluted WTC and various dilutions of the WTC } \\
\text { at temperatures of } 25,45 \text {, and } 65^{\circ} \mathrm{C} \text {. }\end{array}$ & $\begin{array}{l}\text { Determine } \\
\text { viscosity, SpG, } \\
\text { suspended solids } \\
\text { (See Table 4, } \\
\text { Item 3). }\end{array}$ \\
\hline
\end{tabular}


Table 1. Base Case Operating Scenario Evaluation. (8 Sheets)

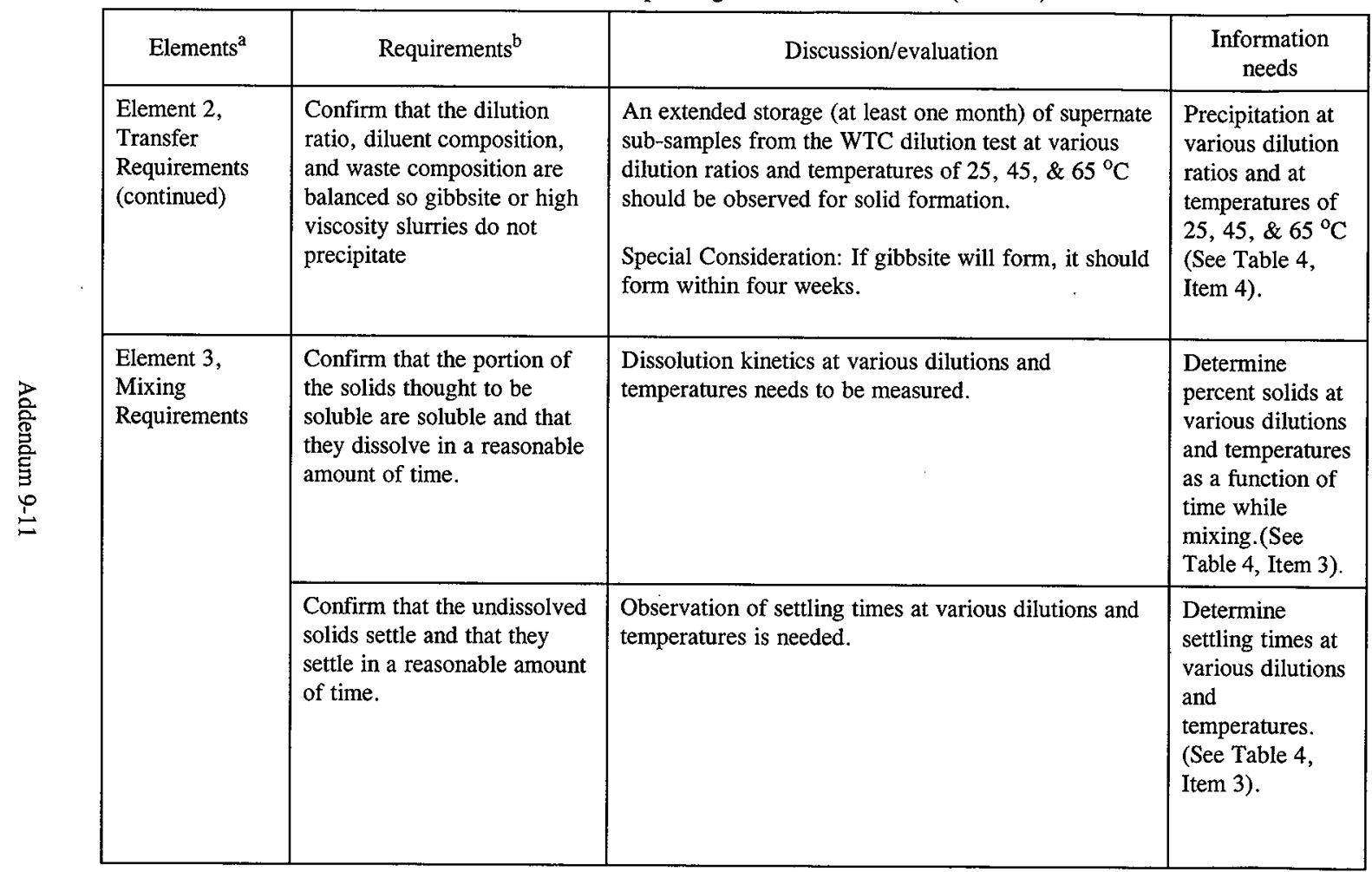


Table 1. Base Case Operating Scenario Evaluation. (8 Sheets)

\begin{tabular}{|c|c|c|c|}
\hline Elements $^{\mathrm{a}}$ & Requirements $^{b}$ & Discussion/evaluation & $\begin{array}{l}\text { Information } \\
\text { needs }\end{array}$ \\
\hline $\begin{array}{l}\text { Element } 3 \text {, } \\
\text { Mixing } \\
\text { Requirements } \\
\text { (continued) }\end{array}$ & $\begin{array}{l}\text { Confirm that the baseline } \\
\text { retrieval equipment that will } \\
\text { be used to mobilize and } \\
\text { transfer the waste is } \\
\text { consistent with the operating } \\
\text { scenario. }\end{array}$ & $\begin{array}{l}\text { Tank } 241-S Y-103 \text { contains crust, supernate, and salt } \\
\text { slurry/sludge layers. The equipment required to } \\
\text { mobilize and retrieve the waste includes mixer pumps } \\
\text { and a transfer pump with water (and caustic) dilution } \\
\text { capability (Boston 1997). This is consistent with the } \\
\text { equipment identified in the base case operating } \\
\text { scenario (Kirkbride et al. 1997). }\end{array}$ & $\begin{array}{l}\text { No further } \\
\text { information } \\
\text { needed. }\end{array}$ \\
\hline \multirow[t]{2}{*}{$\begin{array}{l}\text { Element } 4 \text { - Part } \\
\text { 1: Envelope } \\
\text { Requirements } \\
\text { These limits } \\
\text { apply to the } \\
\text { feed actually } \\
\text { delivered to the } \\
\text { private } \\
\text { contractors. }\end{array}$} & $\begin{array}{l}\text { Concentration limits for the } \\
\text { chemical and radionuclide } \\
\text { content of the feed (DOE-RL } \\
\text { 1996, Section C.6). } \\
\text { See Section } 2.0 \text {, Tables } 1 \\
\text { and } 2 \text { (in main report). }\end{array}$ & $\begin{array}{l}\text { Either Envelope A or C limits will apply to Batch } 11 \text {. } \\
\text { The limits are identical except that the Envelope C } \\
\text { limits for TOC, } \mathrm{SO}_{4}, \mathrm{TRU} \text {, and }{ }^{90} \mathrm{Sr} \text { are higher. } \\
\text { The TWRSO\&UP (Kirkbride et al. 1997, Tables I-1 } \\
\text { and I-3) compared the point estimates }{ }^{2} \text { of the } \\
\text { composition of the feed from } 241-\mathrm{SY}-103 \text { to the } \\
\text { Envelope A limits and indicate that the tank waste } \\
\text { meets all criteria except for TOC. If the TOC limit is } \\
\text { not relaxed, then the waste will be classified as } \\
\text { Envelope C. }\end{array}$ & $\begin{array}{l}\text { Chemical and } \\
\text { radionuclide } \\
\text { analyses from } \\
\text { tests (See Table } \\
4 \text {, Item 5). }\end{array}$ \\
\hline & $\begin{array}{l}\text { Concentration limit for the } \\
\text { sodium concentration of the } \\
\text { feed: } 3 \underline{\mathrm{M}} \geq[\mathrm{Na}] \geq 14 \underline{\mathrm{M}} \\
\text { (DOE-RL } 1996 \text {, Section } \\
\text { C.6). }\end{array}$ & During process testing [Na] will be measured. & $\begin{array}{l}\text { [Na] } \\
\text { measurement } \\
\text { (See Table 4, } \\
\text { Item 6). }\end{array}$ \\
\hline
\end{tabular}


Table 1. Base Case Operating Scenario Evaluation. (8 Sheets)

\begin{tabular}{|c|c|c|c|}
\hline Elements $^{\mathrm{a}}$ & Requirements ${ }^{b}$ & Discussion/evaluation & $\begin{array}{l}\text { Information } \\
\text { needs }\end{array}$ \\
\hline \multirow[t]{2}{*}{$\begin{array}{l}\text { Element } 4 \text { - Part } \\
\text { 1: Envelope } \\
\text { Requirements } \\
\text { (continued) }\end{array}$} & $\begin{array}{l}\text { Insoluble solids fraction limit } \\
\text { will not exceed } 5 \text { volume \% } \\
\text { (DOE-RL 1996, Section } \\
\text { C.6). }\end{array}$ & $\begin{array}{l}\text { The contracts do not define how the volume percent } \\
\text { insoluble solids will be measured. } \\
\text { During the process test, the quantity of solids for } \\
\text { various WTC dilutions will be measured over the } \\
\text { temperature range of } 25 \text { to } 65^{\circ} \mathrm{C} \text {. }\end{array}$ & $\begin{array}{l}\text { Insoluble solids } \\
\text { measurement } \\
\text { (See Table } 4 \text {, } \\
\text { Item } 7 \text { ). }\end{array}$ \\
\hline & $\begin{array}{l}\text { Operating Specifications } \\
\text { from OSD-T-151-00007 } \\
\text { (DOE-RL 1996, Section C.6 } \\
\text { invokes the OSD by } \\
\text { reference). } \\
\text { See Section } 2.0 \text {, Table } 3 \text { (in } \\
\text { main report). }\end{array}$ & $\begin{array}{l}\text { The contract does not explicitly state which } \\
\text { specifications from the OSD apply to the waste. The } \\
\text { PHMC assumes that the Tank Composition (7.2.1) } \\
\text { and Heat Generation Rate }(7.2 .8 \text { ) limits apply to the } \\
\text { waste. These limits are shown in Section } 2.0 \text { ( Table } \\
\text { 3) of the main report. } \\
\text { The TWRSO\&UP (Kirkbride et al. 1997, Section } \\
3.1 .1 .6 \text { ) compared the point estimates of the } \\
\text { composition of the waste as staged in } 241-\mathrm{AP}-102 \text { and } \\
-104 \text { with the Tank Composition (Tank Corrosion) } \\
\text { specifications. All limits were satisfied for Batch } 11 \text {. } \\
\text { Uncertainty is not an issue since the [OH], [NO } 2 \text { and } \\
\text { [NO }{ }_{3} \text { in the staging tanks can be adjusted if needed } \\
\text { before the feed qualification samples are taken. } \\
\text { The TWRSO\&UP (Section } 3.1 .1 .6 \text { ) also evaluated the } \\
\text { heat generation rate rule and found that all limits were } \\
\text { satisfied for Batch } 11 \text {, decayed to the estimated time } \\
\text { of delivery. The estimated heat generation rate for } \\
\text { Batch } 11 \text { is approximately } 3,500 \text { BTU/hr. This is } \\
\text { well within the maximum limit of } 70,000 \text { BTU/hr. } \\
\text { Conformance with OSD factors is achieved for all } \\
\text { known factors. }\end{array}$ & $\begin{array}{l}\text { During the } \\
\text { process testing, } \\
\text { full analysis is } \\
\text { needed for } \\
\text { Envelopes A and } \\
\text { C, including } \\
{ }^{137} \text { Cs (See } \\
\text { Table 4, Item 8). }\end{array}$ \\
\hline
\end{tabular}


Table 1. Base Case Operating Scenario Evaluation. (8 Sheets)

\begin{tabular}{|c|c|c|c|}
\hline Elements $^{\mathrm{a}}$ & Requirements $^{b}$ & Discussion/evaluation & $\begin{array}{l}\text { Information } \\
\text { needs }\end{array}$ \\
\hline \multirow[t]{2}{*}{$\begin{array}{l}\text { Element } 4 \text { - Part } \\
\text { 1: Envelope } \\
\text { Requirements } \\
\text { (continued) }\end{array}$} & $\begin{array}{l}\text { Maximum }{ }^{137} \mathrm{Cs} \\
\text { concentration of } 5.86 \mathrm{E} 10 \\
\text { Bq/liter }(6 \mathrm{Ci} / \mathrm{gal}) \\
\\
\text { Maximum } \\
\text { of } 4.04 \mathrm{E} 5 \mu \mathrm{Ci} / \mathrm{L} \text {. }\end{array}$ & $\begin{array}{l}\text { This limit is equivalent to } 1.59 \mathrm{E} 6 \mu \mathrm{Ci} / \mathrm{L} \text {. The OSD } \\
\text { limit of } 5.74 \mathrm{E} 5 \mu \mathrm{Ci} / \mathrm{L} \text { is more restrictive. } \\
\text { The tank characterization report estimates the }{ }^{137} \mathrm{Cs} \\
\text { concentration of supernate in } 241-\mathrm{SY}-103 \text { (Hansen et } \\
\text { al. 1996) to be } 4.23 \mathrm{E} 2 \mu \mathrm{Ci} / \mathrm{L} \text {. The solids } \\
\text { concentration is between } 1.34 \mathrm{E} 2 \text { and } 2.50 \mathrm{E} 2 \mu \mathrm{Ci} / \mathrm{g} \text {. } \\
\text { Clearly, the }{ }^{137} \mathrm{Cs} \text { concentration will be well below } \\
\text { the limit for this waste. } \\
\text { The tank characterization report estimates the }{ }^{90} \mathrm{Sr} \\
\text { concentration of supernate in } 241-\mathrm{SY}-103 \text { (Hansen } \\
\text { 1996) to be } 2.98 \mu \mathrm{Ci} / \mathrm{L} \text {. The solids concentration is } \\
\text { between } 1.12 \text { and } 34.8 \mu \mathrm{Ci} / \mathrm{g} \text {. Clearly, the }{ }^{90} \mathrm{Sr} \\
\text { concentration is well below the limit for this waste. } \\
\text { Conformance with OSD factors is achieved. }\end{array}$ & $\begin{array}{l}\text { Samples should } \\
\text { be analyzed } \\
\text { during process } \\
\text { testing, but all } \\
\text { indications are } \\
\text { that the levels of } \\
{ }^{137} \mathrm{Cs} \text { and }{ }^{90} \mathrm{Sr} \\
\text { are well below } \\
\text { the applicable } \\
\text { limits. }\end{array}$ \\
\hline & $\begin{array}{l}\text { The PHMC assumed } \\
\text { minimum limits to } \\
\text { distinguish between Envelope } \\
A \text { and } C \text { and between } \\
\text { Envelopes } A \text { and } B\end{array}$ & $\begin{array}{l}\text { The discriminators for Envelopes } \mathrm{A} \text { and } \mathrm{C} \text { are } \mathrm{SO}_{4} \text {, } \\
\text { TOC, TRU, and }{ }^{90} \mathrm{Sr} \text {. }\end{array}$ & $\begin{array}{l}\text { Determine } \mathrm{SO}_{4} \text {, } \\
\text { TOC, TRU, and } \\
{ }^{90} \mathrm{Sr} \\
\text { concentrations } \\
\text { (See Table } 4 \text {, } \\
\text { Item 9). }\end{array}$ \\
\hline
\end{tabular}


Table 1. Base Case Operating Scenario Evaluation. (8 Sheets)

\begin{tabular}{|c|c|c|c|}
\hline Elements $^{\mathrm{a}}$ & Requirements $^{b}$ & Discussion/evaluation & $\begin{array}{l}\text { Information } \\
\text { needs }\end{array}$ \\
\hline $\begin{array}{l}\text { Element } 4 \text { - Part } \\
\text { 2: Quantity } \\
\text { Requirements }\end{array}$ & $\begin{array}{l}\text { Batch size (mass of sodium) } \\
\text { constraints (from the } \\
\text { contracts) } 2100 \mathrm{MT} \text { Na. } \\
\text { PHMC targeted batch size } \\
\text { range (from the ICD (PHMC } \\
\text { 1997, Table 3D): } 100-600 \\
\text { MT Na. } \\
\text { PHMC desired batch } 11 \text { size } \\
\text { (from Operating Scenario): } \\
789 \text { MT Na (Kirkbride et al. } \\
\text { 1997, Table 3.1-5) }\end{array}$ & $\begin{array}{l}\text { During process testing, the amount of recoverable } \mathrm{Na} \\
\text { should be measured. The TCR puts the inventory of } \\
\mathrm{Na} \text { at } 3.17 \mathrm{E}+5 \mathrm{~kg} \text { for the convective layer and } \\
4.02 \mathrm{E}+5 \text { for the non-convective layer, for a total of } \\
7.19 \mathrm{E}+5 \mathrm{~kg} \text { or } 719 \mathrm{MT} \text {. Note that some } 241-\mathrm{SY}-101 \\
\text { waste is planned for batch } 11 \text { as well. }\end{array}$ & $\begin{array}{l}\text { Determine } \mathrm{Na} \\
\text { quantity (See } \\
\text { Table } 4 \text {, } \\
\text { Item } 10 \text { ). }\end{array}$ \\
\hline \multirow[t]{4}{*}{$\begin{array}{l}\text { Element } 5 \text { - } \\
\text { Miscellaneous } \\
\text { Inputs }\end{array}$} & $\begin{array}{l}\text { Physical form of Tank } T \\
\text { contents }\end{array}$ & $\begin{array}{l}\text { From Hansen et al. (1996): } 241-S Y-103 \text { has a crust } \\
\text { layer of unknown depth- the historical estimate is less } \\
\text { than } 2 \text { inches. The supernate layer is approximately } \\
3.51 \mathrm{~m}(11.5 \mathrm{ft}) \text {, and the solids layer is approximately } \\
3.34 \mathrm{~m}(11.0 \mathrm{ft}) \text {. There is no hard pan. }\end{array}$ & $\begin{array}{l}\text { No further } \\
\text { information is } \\
\text { needed }\end{array}$ \\
\hline & $\begin{array}{l}\text { Heel from prior batch } \\
\text { remaining in staging tanks }\end{array}$ & $\begin{array}{l}\text { 10-in. supernate heels and sludge remaining in } 241- \\
\text { SY- } 102 \text { need to be addressed. Heels remaining in } \\
\text { East Area staging tanks may also need to be } \\
\text { addressed. }\end{array}$ & $\begin{array}{l}\text { Process test } \\
\text { needed.(See } \\
\text { Table } 4 \text {, } \\
\text { Item 10). }\end{array}$ \\
\hline & Shimming Batch 11 & No shimming is anticipated. & $\begin{array}{l}\text { No further } \\
\text { information is } \\
\text { needed }\end{array}$ \\
\hline & RL direction & $\begin{array}{l}\text { No changes to applicable M\&I ICD requirements } \\
\text { have been made to date. }\end{array}$ & $\begin{array}{l}\text { No further } \\
\text { information is } \\
\text { needed }\end{array}$ \\
\hline
\end{tabular}

a. Elements are taken from the Decision Rule statement in Section 4.0 of PSDQO-01.

b. Requirements are taken from Sections 4.1, 4.2, 4.3, 4.4, and 4.5 of PSDQO-01. 
Table 2. Alternative Case 1 Operating Scenario Evaluation. (6 Sheets)

\begin{tabular}{|c|c|c|c|}
\hline Elements $^{\mathrm{a}}$ & Requirements $^{b}$ & Discussion/evaluation & $\begin{array}{l}\text { Information } \\
\text { needs }\end{array}$ \\
\hline $\begin{array}{l}\text { Element 1, } \\
\text { Dilution Ratio } \\
\text { and Diluent } \\
\text { Composition }\end{array}$ & $\begin{array}{l}\text { Determine the desired } \\
\text { dilution ratio and diluent } \\
\text { composition for each waste } \\
\text { transfer. }\end{array}$ & $\begin{array}{l}\text { Process testing of the supernate composite and of diluted } \\
\text { salt slurry composite is needed at various dilutions over } \\
\text { the temperature range of } 25^{\circ} \mathrm{C} \text { to } 65^{\circ} \mathrm{C} \text {. }\end{array}$ & $\begin{array}{l}\text { Desired dilution } \\
\text { ratio and diluent } \\
\text { composition (See } \\
\text { Table } 4 \text {, } \\
\text { Item 12) }\end{array}$ \\
\hline \multirow[t]{3}{*}{$\begin{array}{l}\text { Element 2, } \\
\text { Transfer } \\
\text { Requirements }\end{array}$} & $\begin{array}{l}\text { Confirm that the as-retrieved } \\
\text { waste (including dilution } \\
\text { water or caustic) remains } \\
\text { below saturation in major } \mathrm{Na} \\
\text { salts during the transfer to } \\
\text { the staging tank. }\end{array}$ & $\begin{array}{l}\text { A process test is needed to confirm that the as-retrieved } \\
\text { waste streams (including dilution water or caustic) } \\
\text { remain below saturation in major Na salts during the } \\
\text { transfer to the staging tank. The two streams are the } \\
\text { supernate and salt slurry from the tank. Testing should } \\
\text { be conducted at various dilutions and temperatures. }\end{array}$ & $\begin{array}{l}\text { Confirm that the } \\
\text { two streams are } \\
\text { below saturation } \\
\text { in major Na salts } \\
\text { (See Table } 4 \text {, } \\
\text { Item 13). }\end{array}$ \\
\hline & $\begin{array}{l}\text { Confirm that the dilution } \\
\text { ratio, diluent composition, } \\
\text { and waste composition are } \\
\text { balanced so gibbsite or high } \\
\text { viscosity slurries do not } \\
\text { precipitate. }\end{array}$ & $\begin{array}{l}\text { An extended storage (at least one month) of supernate } \\
\text { and salt slurry subsamples from the dilution should be } \\
\text { observed for solid formation over the temperature range } \\
\text { of } 25 \text { to } 65^{\circ} \mathrm{C} \text {. } \\
\text { Special Consideration: If gibbsite will form, it should } \\
\text { form within four weeks. }\end{array}$ & $\begin{array}{l}\text { Precipitation at } \\
\text { various dilution } \\
\text { ratios over the } \\
\text { temperature } \\
\text { range of } 25 \text { to } 65 \\
{ }^{\circ} \mathrm{C} \text { (See Table } 4 \text {, } \\
\text { Item 14). }\end{array}$ \\
\hline & $\begin{array}{l}\text { Confirm that the undissolved } \\
\text { solids settle and that they } \\
\text { settle in a reasonable amount } \\
\text { of time. }\end{array}$ & $\begin{array}{l}\text { Observation of settling times at various dilutions and } \\
\text { temperatures is needed. }\end{array}$ & $\begin{array}{l}\text { Determine } \\
\text { settling times at } \\
\text { various dilutions } \\
\text { and } \\
\text { temperatures. } \\
\text { See Table } 4 \text {, } \\
\text { Item 15) }\end{array}$ \\
\hline
\end{tabular}


Table 2. Alternative Case 1 Operating Scenario Evaluation. (6 Sheets)

\begin{tabular}{|c|c|c|c|}
\hline Elements $^{\mathrm{a}}$ & Requirements $^{b}$ & Discussion/evaluation & $\begin{array}{l}\text { Information } \\
\text { needs }\end{array}$ \\
\hline $\begin{array}{l}\text { Element 2, } \\
\text { Transfer } \\
\text { Requirements } \\
\text { (continued) }\end{array}$ & $\begin{array}{l}\text { Confirm that the baseline } \\
\text { retrieval equipment that will } \\
\text { be used to mobilize and } \\
\text { transfer the waste is } \\
\text { consistent with the operating } \\
\text { scenario. }\end{array}$ & $\begin{array}{l}\text { Tank 241-SY-103 contains crust, supernate, and salt } \\
\text { slurry/sludge layers. The equipment required to } \\
\text { mobilize and retrieve the waste includes mixer pumps } \\
\text { and a transfer pump with water (and caustic) dilution } \\
\text { capability (Boston 1997). This is consistent with the } \\
\text { equipment identified in the base case operating scenario } \\
\text { (Kirkbride et al. 1997). }\end{array}$ & $\begin{array}{l}\text { No further } \\
\text { information } \\
\text { needed. }\end{array}$ \\
\hline $\begin{array}{l}\text { Element } 4 \text { - Part } \\
\text { 1: Envelope } \\
\text { Requirements } \\
\text { These limits } \\
\text { apply to the feed } \\
\text { actually } \\
\text { delivered to the } \\
\text { private } \\
\text { contractors. }\end{array}$ & $\begin{array}{l}\text { Concentration limits for the } \\
\text { chemical and radionuclide } \\
\text { content of the feed (DOE-RL } \\
\text { 1996, Section C.6). } \\
\text { See Section } 2.0, \text { Tables } 1 \\
\text { and } 2 \text { (in main report) for } \\
\text { the limits. }\end{array}$ & $\begin{array}{l}\text { Either Envelope A or } \mathrm{Climits} \text { will apply to Batch } 11 \text {. } \\
\text { The limits are identical except that the Envelope } \mathrm{C} \text { limits } \\
\text { for TOC, } \mathrm{SO}_{4} \text {, TRU, and }{ }^{90} \mathrm{Sr} \text { are higher. } \\
\text { The TWRSO\&UP (Kirkbride et al. 1997, Tables I-1 and } \\
\text { I-3) compared the point estimates }{ }^{1} \text { of the composition of } \\
\text { the feed from } 241-\mathrm{SY}-103 \text { to the Envelope A limits and } \\
\text { indicate that the tank waste meets all criteria except for } \\
\text { TOC. If the TOC limit is not relaxed,, then the waste } \\
\text { will be classified as Envelope C. }\end{array}$ & $\begin{array}{l}\text { Chemical and } \\
\text { radionuclide } \\
\text { analyses from } \\
\text { process testing } \\
\text { (See Table 4, } \\
\text { Item 16). }\end{array}$ \\
\hline
\end{tabular}

${ }^{1}$ These point estimates were based on a thermodynamic model (ESP) which was used to estimate the liquid phase composition of the waste. 
Table 2. Alternative Case 1 Operating Scenario Evaluation. (6 Sheets)

\begin{tabular}{|c|c|c|c|}
\hline Elements $^{\mathrm{a}}$ & Requirements $^{b}$ & Discussion/evaluation & $\begin{array}{l}\text { Information } \\
\text { needs }\end{array}$ \\
\hline $\begin{array}{l}\text { Element } 4 \text { - Part } \\
\text { 2: Quantity } \\
\text { Requirements } \\
\text { are Satisfied }\end{array}$ & $\begin{array}{l}\text { Batch size (mass of sodium) } \\
\text { constraints (from the } \\
\text { contracts) } \geq 100 \mathrm{MT} \text { Na. } \\
\text { PHMC targeted batch size } \\
\text { range (from the ICD (PHMC } \\
\text { 1997, Table 3D): } 100-600 \\
\text { MT Na. } \\
\text { PHMC desired batch } 11 \text { size } \\
\text { (from Operating Scenario): } \\
789 \text { MT Na (Kirkbride et al. } \\
\text { 1997, Table 3.1-5) }\end{array}$ & $\begin{array}{l}\text { During process testing, the amount of recoverable } \mathrm{Na} \\
\text { should be measured. The TCR puts the inventory of } \mathrm{Na} \\
\text { at } 3.17 \mathrm{E}+5 \mathrm{~kg} \text { for the convective layer and } 4.02 \mathrm{E}+5 \mathrm{for} \\
\text { the non-convective layer, for a total of } 7.19 \mathrm{E}+5 \mathrm{~kg} \text { or } \\
719 \mathrm{MT} \text {. Note that some } 241-\mathrm{SY}-101 \text { waste is planned } \\
\text { for batch } 11 \text { as well. }\end{array}$ & $\begin{array}{l}\text { Determine } \mathrm{Na} \\
\text { quantity (See } \\
\text { Table } 4 \text {, } \\
\text { Items } 17 \text { and } \\
18)\end{array}$ \\
\hline \multirow[t]{3}{*}{$\begin{array}{l}\text { Element } 5 \text { - } \\
\text { Miscellaneous } \\
\text { Inputs }\end{array}$} & $\begin{array}{l}\text { Physical form of Tank } \mathrm{T} \\
\text { contents }\end{array}$ & $\begin{array}{l}\text { From Hansen et al. (1996): } 241-S Y-103 \text { has a crust layer } \\
\text { of unknown depth- the historical estimate is less than } 2 \\
\text { inches. The supernate layer is approximately } 3.51 \mathrm{~m} \\
(11.5 \mathrm{ft}) \text {, and the solids layer is approximately } 3.34 \mathrm{~m} \\
(11.0 \mathrm{ft}) \text {. There is no hard pan. }\end{array}$ & $\begin{array}{l}\text { No further } \\
\text { information is } \\
\text { needed }\end{array}$ \\
\hline & $\begin{array}{l}\text { Heel from prior batch } \\
\text { remaining in staging tanks }\end{array}$ & $\begin{array}{l}10 \text {-in. supernate heels and sludge remaining in } 241-S Y- \\
102 \text { need to be addressed. Heels remaining in East Area } \\
\text { tanks may also need to be addressed. }\end{array}$ & $\begin{array}{l}\text { Process test } \\
\text { needed. }\end{array}$ \\
\hline & Shimming Batch 11 & No shimming is anticipated. & $\begin{array}{l}\text { No further } \\
\text { information is } \\
\text { needed }\end{array}$ \\
\hline
\end{tabular}

${ }^{2}$ Elements are taken from the Decision Rule statement in Section 6.1 of PSDQO-01.

${ }^{b}$ Requirements are taken from Sections 4.1, 4.2, 4.3, 4.4, and 4.5 of PSDQO-01. 
Table 3. Alternative Case 2 Operating Scenario Evaluation. (9 Sheets)

\begin{tabular}{|c|c|c|c|}
\hline Elements $^{\mathrm{a}}$ & Requirements $^{\mathrm{b}}$ & Discussion/evaluation & $\begin{array}{l}\text { Information } \\
\text { needs }\end{array}$ \\
\hline $\begin{array}{l}\text { Element 1, } \\
\text { Dilution Ratio } \\
\text { and Diluent } \\
\text { Composition }\end{array}$ & $\begin{array}{l}\text { Determine the desired } \\
\text { dilution ratio and diluent } \\
\text { composition for each waste } \\
\text { transfer. }\end{array}$ & $\begin{array}{l}\text { A test plan, based on instruction provided by the } \\
\text { Disposal Program (e.g. Garfield 1997), is need for } \\
\text { process testing. The plan will obtain the following } \\
\text { information for the } 241-S Y-103 \text { WTC. Required dilution } \\
\text { ratio to prevent precipitation over the temperature range } \\
\text { of } 25^{\circ} \mathrm{C} \text { to } 65^{\circ} \mathrm{C} \text {. } \\
\text { Process testing for } 241-\mathrm{SY}-101 \text { WTC will be completed } \\
\text { per } 241-\mathrm{SY}-101 \text { addendum. }\end{array}$ & $\begin{array}{l}\text { Desired dilution } \\
\text { ratio and diluent } \\
\text { composition (See } \\
\text { Table 4, Item 1). }\end{array}$ \\
\hline \multirow[t]{2}{*}{$\begin{array}{l}\text { Element } 2 \text {, } \\
\text { Transfer } \\
\text { Requirements }\end{array}$} & $\begin{array}{l}\text { Confirm that the as-retrieved } \\
\text { waste (including dilution } \\
\text { water or caustic) remains } \\
\text { below saturation in major } \mathrm{Na} \\
\text { salts during the transfer to } \\
\text { the staging tank. }\end{array}$ & $\begin{array}{l}\text { A process test is needed to confirm that the as-retrieved } \\
\text { waste (WTC including dilution water or caustic) remains } \\
\text { below saturation in major Na salts during the transfer to } \\
\text { the staging tank. } \\
\text { Process testing for } 241-S Y-101 \text { WTC will be completed } \\
\text { per } 241-S Y-101 \text { addendum. }\end{array}$ & $\begin{array}{l}\text { Confirm that the } \\
\text { diluted WTC is } \\
\text { below saturation } \\
\text { in major Na salts } \\
\text { (See Table 4, } \\
\text { Item 2). }\end{array}$ \\
\hline & $\begin{array}{l}\text { Confirm that the as-retrieved } \\
\text { waste (including dilution } \\
\text { water or caustic) remain at } \\
\text { or below viscosity of } 10 \mathrm{cP} \text {, } \\
\text { at or below a } 1.5 \mathrm{SpG} \text {, and } \\
\text { at or below } 30 \text { percent solids } \\
\text { by volume during the } \\
\text { transfer to the staging tank. }\end{array}$ & $\begin{array}{l}\text { A process test is needed. The test will determine } \\
\text { viscosity, density, and quantity of settled solids for the } \\
\text { undiluted WTC and various dilutions of the WTC at } \\
\text { temperatures of } 25,45 \text {, and } 65^{\circ} \mathrm{C} \text {. } \\
\text { Process testing for } 241-\mathrm{SY}-101 \text { WTC will be completed } \\
\text { per } 241 \text {-SY-101 addendum. }\end{array}$ & $\begin{array}{l}\text { Determine } \\
\text { viscosity, } \mathrm{SpG}, \\
\text { suspended solids } \\
\text { (See Table 4, } \\
\text { Item 3). }\end{array}$ \\
\hline $\begin{array}{l}\text { Element 2, } \\
\text { Transfer } \\
\text { Requirements } \\
\text { (continued) }\end{array}$ & $\begin{array}{l}\text { Confirm that the dilution } \\
\text { ratio, diluent composition, } \\
\text { and waste composition are } \\
\text { balanced so gibbsite or high } \\
\text { viscosity slurries do not } \\
\text { precipitate }\end{array}$ & $\begin{array}{l}\text { An extended storage (at least one month) of supernate } \\
\text { sub-samples from the WTC dilution test at various } \\
\text { dilution ratios and temperatures of } 25,45 \text {, and } 65^{\circ} \mathrm{C} \\
\text { should be observed for solid formation. } \\
\text { Special Consideration: If gibbsite will form, it should } \\
\text { form within four weeks. }\end{array}$ & $\begin{array}{l}\text { Precipitation at } \\
\text { various dilution } \\
\text { ratios and at } \\
\text { temperatures of } \\
25,45 \text {, and } \\
65^{\circ} \mathrm{C} \text { (See } \\
\text { Table 4, Item 4). }\end{array}$ \\
\hline
\end{tabular}


Table 3. Alternative Case 2 Operating Scenario Evaluation. (9 Sheets)

\begin{tabular}{|c|c|c|c|}
\hline Elements $^{\mathrm{a}}$ & Requirements ${ }^{\mathrm{b}}$ & Discussion/evaluation & $\begin{array}{c}\begin{array}{c}\text { Information } \\
\text { needs }\end{array} \\
\end{array}$ \\
\hline $\begin{array}{l}\text { Element 3, } \\
\text { Mixing } \\
\text { Requirements }\end{array}$ & $\begin{array}{l}\text { Confirm that the portion of } \\
\text { the solids thought to be } \\
\text { soluble are soluble and that } \\
\text { they dissolve in a reasonable } \\
\text { amount of time. }\end{array}$ & $\begin{array}{l}\text { Dissolution kinetics at various dilutions and temperatures } \\
\text { needs to be measured. } \\
\text { Note: Confirmation that a mixer pump can provide the } \\
\text { necessary amount of mixing to dissolve the solids in the } \\
\text { tank in a reasonable amount of time is within the scope } \\
\text { of the Equipment Design PSDQO. } \\
\text { For this alternative, the waste will be combined with } \\
\text { waste from } 241 \text {-SY-101. Therefore, compatibility with } \\
\text { the } 241-S Y-101 \text { WTC is necessary. }\end{array}$ & $\begin{array}{l}\text { Determine } \\
\text { percent solids at } \\
\text { various dilutions } \\
\text { and temperatures } \\
\text { as a function of } \\
\text { time while } \\
\text { mixing (See } \\
\text { Table } 4 \text {, } \\
\text { Item 19). } \\
\text { Confirm } \\
\text { compatibility } \\
\text { with } 241-S Y-101 \\
\text { WTC (See Table } \\
\text { 4, Item 20). }\end{array}$ \\
\hline $\begin{array}{l}\text { Element } 4 \text { - Part } \\
\text { 1: Envelope } \\
\text { Requirements } \\
\text { These limits } \\
\text { apply to the } \\
\text { feed actually } \\
\text { delivered to the } \\
\text { private } \\
\text { contractors. }\end{array}$ & $\begin{array}{l}\text { Confirm that the undissolved } \\
\text { solids settle and that they } \\
\text { settle in a reasonable amount } \\
\text { of time. }\end{array}$ & $\begin{array}{l}\text { Observation of settling times at various dilutions and } \\
\text { temperatures is needed. }\end{array}$ & $\begin{array}{l}\text { Determine } \\
\text { settling times at } \\
\text { various dilutions } \\
\text { and temperatures } \\
\text { (See Table } 4 \text {, } \\
\text { Item 21). }\end{array}$ \\
\hline
\end{tabular}


Table 3. Alternative Case 2 Operating Scenario Evaluation. (9 Sheets)

\begin{tabular}{|c|c|c|c|}
\hline Elements ${ }^{\mathbf{a}}$ & Requirements ${ }^{b}$ & Discussion/evaluation & $\begin{array}{l}\text { Information } \\
\text { needs }\end{array}$ \\
\hline \multirow[t]{4}{*}{$\begin{array}{l}\text { Element } 4 \text { - Part } \\
\text { 1: Envelope } \\
\text { Requirements } \\
\text { (continued) }\end{array}$} & $\begin{array}{l}\text { Confirm that the baseline } \\
\text { retrieval equipment that will } \\
\text { be used to mobilize and } \\
\text { transfer the waste is } \\
\text { consistent with the operating } \\
\text { scenario. }\end{array}$ & $\begin{array}{l}\text { Tank 241-SY-103 contains crust, supernate, and salt } \\
\text { slurry/sludge layers. The equipment required to mobilize } \\
\text { and retrieve the waste includes mixer pumps and a } \\
\text { transfer pump with water (and caustic) dilution capability } \\
\text { (Boston 1997). This is consistent with the equipment } \\
\text { identified in the base case operating scenario (Kirkbride } \\
\text { et al. 1997). }\end{array}$ & $\begin{array}{l}\text { No further } \\
\text { information } \\
\text { needed. }\end{array}$ \\
\hline & $\begin{array}{l}\text { Concentration limits for the } \\
\text { chemical and radionuclide } \\
\text { content of the feed (DOE-RL } \\
\text { 1996, Section C.6). } \\
\text { See Section 2.0, Tables } 1 \\
\text { and } 2 \text { (in main report). }\end{array}$ & $\begin{array}{l}\text { Either Envelope A or C limits will apply to Batch } 11 \text {. } \\
\text { The limits are identical except that the Envelope C limits } \\
\text { for TOC, } \mathrm{SO}_{4}, \mathrm{TRU} \text {, and }{ }^{90} \mathrm{Sr} \text { are higher. } \\
\text { The TWRSO\&UP (Kirkbride et al. } 1997 \text {, Tables I-1 and } \\
\text { I-3) compared the point estimates }{ }^{1} \text { of the composition of } \\
\text { the feed from } 241-\mathrm{SY}-103 \text { to the Envelope C limits and } \\
\text { indicate that the tank waste meets all criteria. }\end{array}$ & $\begin{array}{l}\text { Chemical and } \\
\text { radionuclide } \\
\text { analyses from } \\
\text { tests (See Table } \\
4, \text { Item 22). }\end{array}$ \\
\hline & $\begin{array}{l}\text { Concentration limit for the } \\
\text { sodium concentration of the } \\
\text { feed: } 3 \underline{M} \geq[N a] \geq 14 \mathrm{M} \\
\text { (DOE-RL 1996, Section } \\
\text { C.6). }\end{array}$ & During process testing $[\mathrm{Na}]$ will be measured. & $\begin{array}{l}\text { [Na] } \\
\text { measurement } \\
\text { (See Table 4, } \\
\text { Item 22). }\end{array}$ \\
\hline & $\begin{array}{l}\text { Insoluble solids fraction limit } \\
\text { will not exceed } 5 \text { volume \% } \\
\text { (DOE-RL 1996, Section } \\
\text { C.6). }\end{array}$ & $\begin{array}{l}\text { The contracts do not define how the volume percent } \\
\text { insoluble solids will be measured. } \\
\text { During the process test, the quantity of solids for various } \\
\text { WTC dilutions will be measured over the temperature } \\
\text { range of } 25 \text { to } 65^{\circ} \mathrm{C} \text {. }\end{array}$ & $\begin{array}{l}\text { Insoluble solids } \\
\text { measurement } \\
\text { (See Table 4, } \\
\text { Item 21). }\end{array}$ \\
\hline
\end{tabular}

${ }^{1}$ These point estimates were based on a thermodynamic model (ESP) that was used to estimate the liquid phase composition of the waste. 
Table 3. Alternative Case 2 Operating Scenario Evaluation. (9 Sheets)

\begin{tabular}{|c|c|c|c|}
\hline Elements $^{\mathrm{a}}$ & Requirements ${ }^{b}$ & Discussion/evaluation & $\begin{array}{c}\text { Information } \\
\text { needs }\end{array}$ \\
\hline $\begin{array}{l}\text { Element } 4 \text { - Part } \\
\text { 1: Envelope } \\
\text { Requirements } \\
\text { (continued) }\end{array}$ & $\begin{array}{l}\text { Operating Specifications } \\
\text { from OSD-T-151-00007 } \\
\text { (DOE-RL 1996, Section C.6 } \\
\text { invokes the OSD by } \\
\text { reference). } \\
\text { See Section } 2.0 \text { ( Table } 3 \text { ) } \\
\text { of the main report. }\end{array}$ & $\begin{array}{l}\text { The contract does not explicitly state which specifications } \\
\text { from the OSD apply to the waste. The PHMC assumes } \\
\text { that the Tank Composition ( } 7.2 .1 \text { ) and Heat Generation } \\
\text { Rate ( } 7.2 .8 \text { ) limits apply to the waste. These limits are } \\
\text { shown in Section } 2.0 \text { ( Table } 3 \text { ) of the main report. } \\
\text { The TWRSO\&UP (Kirkbride et al. } 1997 \text {, Section } \\
3.1 .1 .6 \text { ) compared the point estimates of the composition } \\
\text { of the waste as staged in } 241-\mathrm{AP}-102 \text { and - } 104 \text { with the } \\
\text { Tank Composition (Tank Corrosion) specifications. All } \\
\text { limits were satisfied for Batch } 11 \text {. Uncertainty is not an } \\
\text { issue since the [OH], [NO } 2 \text { ] and [NO } \mathrm{O}_{3} \text { ] in the staging } \\
\text { tanks can be adjusted if needed before the feed } \\
\text { qualification samples are taken. } \\
\text { The TWRSO\&UP (Section } 3.1 .1 .6 \text { ) also evaluated the } \\
\text { heat generation rate rule and found that all limits were } \\
\text { satisfied for Batch } 11, \text { decayed to the estimated time of } \\
\text { delivery. The estimated heat generation rate for Batch } 11 \\
\text { is approximately } 3,500 \mathrm{BTU} / \mathrm{hr} \text {. This is well within the } \\
\text { maximum limit of } 70,000 \mathrm{BTU} / \mathrm{hr} \text {. } \\
\text { Conformance with OSD factors is achieved for all known } \\
\text { factors. }\end{array}$ & $\begin{array}{l}\text { During the } \\
\text { process testing, } \\
\text { full analysis is } \\
\text { needed for } \\
\text { Envelopes A and } \\
\mathrm{C} \text {, including } \\
{ }^{137} \mathrm{Cs} \text { (See Table } \\
4 \text {, Item 22). }\end{array}$ \\
\hline
\end{tabular}


Table 3. Alternative Case 2 Operating Scenario Evaluation. (9 Sheets)

\begin{tabular}{|c|c|c|c|}
\hline Elements $^{a}$ & Requirements $^{b}$ & Discussion/evaluation & $\begin{array}{c}\text { Information } \\
\text { needs }\end{array}$ \\
\hline \multirow[t]{2}{*}{$\begin{array}{l}\text { Element } 4 \text { - Part } \\
\text { 2: Quantity } \\
\text { Requirements }\end{array}$} & $\begin{array}{l}\text { Maximum }{ }^{137} \mathrm{Cs} \\
\text { concentration of } 5.86 \mathrm{E} 10 \\
\text { Bq/liter }(6 \mathrm{Ci} / \mathrm{gal}) \\
\\
\text { Maximum }{ }^{90} \mathrm{Sr} \text { concentration } \\
\text { of } 4.04 \mathrm{E} 5 \mu \mathrm{Ci} / \mathrm{L} \text {. }\end{array}$ & $\begin{array}{l}\text { This limit is equivalent to } 1.59 \mathrm{E} 6 \mu \mathrm{Ci} / \mathrm{L} \text {. The OSD limit } \\
\text { of } 5.74 \mathrm{E} 5 \mu \mathrm{Ci} / \mathrm{L} \text { is more restrictive. } \\
\text { The tank characterization report estimates the }{ }^{137} \mathrm{Cs} \\
\text { concentration of supernate in } 241-\mathrm{SY}-103 \text { (Hansen et al. } \\
\text { 1996) to be } 4.23 \mathrm{E} 2 \mu \mathrm{Ci} / \mathrm{L} \text {. The solids concentration is } \\
\text { between } 1.34 \mathrm{E} 2 \text { and } 2.50 \mathrm{E} 2 \mu \mathrm{Ci} / \mathrm{g} \text {. Clearly, the }{ }^{137} \mathrm{Cs} \\
\text { concentration will be well below the limit for this waste. } \\
\text { The tank characterization report estimates the }{ }^{90} \mathrm{Sr} \\
\text { concentration of supernate in } 241-\mathrm{SY}-103 \text { (Hansen 1996) } \\
\text { to be } 2.98 \mu \mathrm{Ci} / \mathrm{L} \text {. The solids concentration is between } \\
1.12 \text { and } 34.8 \mu \mathrm{Ci} / \mathrm{g} \text {. Clearly, the }{ }^{90} \mathrm{Sr} \text { concentration is } \\
\text { well below the limit for this waste. } \\
\text { Conformance with OSD factors is achieved. }\end{array}$ & $\begin{array}{l}\text { Samples should } \\
\text { be analyzed } \\
\text { during process } \\
\text { testing, but all } \\
\text { indications are } \\
\text { that the levels of } \\
{ }^{137} \mathrm{Cs} \text { and }{ }^{90} \mathrm{Sr} \\
\text { are well below } \\
\text { the applicable } \\
\text { limits (See Table } \\
\text { 4, Item 22). }\end{array}$ \\
\hline & $\begin{array}{l}\text { The PHMC assumed } \\
\text { minimum limits to } \\
\text { distinguish between } \\
\text { Envelope } \mathrm{A} \text { and } \mathrm{C} \text { and } \\
\text { between Envelopes } \mathrm{A} \text { and B }\end{array}$ & $\begin{array}{l}\text { The discriminators for Envelopes } \mathrm{A} \text { and } \mathrm{C} \text { are } \mathrm{SO}_{4} \text {, } \\
\text { TOC, TRU, and }{ }^{90} \mathrm{Sr} \text {. }\end{array}$ & $\begin{array}{l}\text { Determine } \mathrm{SO}_{4} \text {, } \\
\mathrm{TOC}, \mathrm{TRU} \text {, and } \\
{ }^{90} \mathrm{Sr} \\
\text { concentrations } \\
\text { (See Table } 4 \text {, } \\
\text { Item 22). }\end{array}$ \\
\hline
\end{tabular}


Table 3. Alternative Case 2 Operating Scenario Evaluation. (9 Sheets)

\begin{tabular}{|c|c|c|c|}
\hline Elements $^{\mathrm{a}}$ & Requirements $^{\mathrm{b}}$ & Discussion/evaluation & $\begin{array}{c}\text { Information } \\
\text { needs }\end{array}$ \\
\hline $\begin{array}{l}\text { Element } 4 \text { - Part } \\
\text { 2: Quantity } \\
\text { Requirements } \\
\text { (continued) }\end{array}$ & $\begin{array}{l}\text { Batch size (mass of sodium) } \\
\text { constraints (from the } \\
\text { contracts) } 2100 \mathrm{MT} \mathrm{Na} \text {. } \\
\text { PHMC targeted batch size } \\
\text { range (from the ICD (PHMC } \\
\text { 1997, Table 3D): } 100-600 \\
\text { MT Na. } \\
\text { PHMC desired batch } 11 \text { size } \\
\text { (from Operating Scenario): } \\
789 \text { MT Na (Kirkbride et al. } \\
\text { 1997, Table 3.1-5) }\end{array}$ & $\begin{array}{l}\text { During process testing, the amount of recoverable } \mathrm{Na} \\
\text { should be measured. The TCR puts the inventory of } \mathrm{Na} \\
\text { at } 3.17 \mathrm{E}+5 \mathrm{~kg} \text { for the convective layer and } 4.02 \mathrm{E}+5 \mathrm{for} \\
\text { the non-convective layer, for a total of } 7.19 \mathrm{E}+5 \mathrm{~kg} \text { or } \\
719 \mathrm{MT} \text {. Note that some } 241-\mathrm{SY}-101 \text { waste is planned } \\
\text { for batch } 11 \text { as well. }\end{array}$ & $\begin{array}{l}\text { Determine } \mathrm{Na} \\
\text { quantity (See } \\
\text { Table } 4 \text {, } \\
\text { Item 22). }\end{array}$ \\
\hline \multirow[t]{4}{*}{$\begin{array}{l}\text { Element } 5 \text { - } \\
\text { Miscellaneous } \\
\text { Inputs }\end{array}$} & $\begin{array}{l}\text { Physical form of Tank } \mathrm{T} \\
\text { contents }\end{array}$ & $\begin{array}{l}\text { From Hansen et al. (1996): } 241-S Y-103 \text { has a crust layer } \\
\text { of unknown depth- the historical estimate is less than } 2 \\
\text { inches. The supernate layer is approximately } 3.51 \mathrm{~m} \\
(11.5 \mathrm{ft}) \text {, and the solids layer is approximately } 3.34 \mathrm{~m} \\
(11.0 \mathrm{ft}) . \text { There is no hard pan. }\end{array}$ & $\begin{array}{l}\text { No further } \\
\text { information is } \\
\text { needed }\end{array}$ \\
\hline & $\begin{array}{l}\text { Heel from prior batch } \\
\text { remaining in staging tanks }\end{array}$ & $\begin{array}{l}\text { 10-in. supernate heels and sludge remaining in 241-SY- } \\
102 \text { need to be addressed. Heels remaining in East Area } \\
\text { staging tanks may also need to be addressed. }\end{array}$ & $\begin{array}{l}\text { None, process } \\
\text { test needed (See } \\
\text { Table } 4 \text {, } \\
\text { Item } 11 \text { ). }\end{array}$ \\
\hline & Shimming Batch 11 & No shimming is anticipated. & $\begin{array}{l}\text { No further } \\
\text { information is } \\
\text { needed }\end{array}$ \\
\hline & RL direction & $\begin{array}{l}\text { No changes to applicable M\&I ICD requirements have } \\
\text { been made to date. }\end{array}$ & $\begin{array}{l}\text { No further } \\
\text { information is } \\
\text { needed }\end{array}$ \\
\hline
\end{tabular}

${ }^{\mathrm{a}}$ Elements are taken from the Decision Rule statement in Section 6.1 of PSDQO-01.

${ }^{b}$ Requirements are taken from Sections 4.1, 4.2, 4.3, 4.4, and 4.5 of PSDQO-01. 
Table 4 was developed jointly by TWRS Characterization and Tank Waste Retrieval. It is intended to show what information is still needed, what can be obtained by calculations with existing data, what requires new (or existing) samples, analysis and/or process testing. Where samples are required, the amount and "representativeness" of the sample will be stated. Where analysis is needed, the specific analytes and QA requirements will be stated. If process testing is needed, the amount of sample and goals of the process test will be stated. Appropriate level of end description of QA requirements will be covered in the specific work plan for these limited process tests.

Table 4. Information Needs. (3 Sheets)

\begin{tabular}{|c|c|c|c|}
\hline Item & Information need & Planned resolution & Sample required \\
\hline 1 & $\begin{array}{l}\text { Desired dilution ratio } \\
\text { and diluent composition }\end{array}$ & $\begin{array}{l}\text { Perform lab test: measure minimum dilution } \\
\text { ratio which satisfies all transfer system; } \\
\text { measure maximum dilution ratio where } \\
\text { gibbsite will not become a problem. } \\
\text { Determine desired dilution ratio and diluent. }\end{array}$ & $\begin{array}{l}300 \mathrm{ml} \\
241-\mathrm{SY}-103 \\
\text { WTC. }\end{array}$ \\
\hline 2 & $\begin{array}{l}\text { Confirm a dilution ratio } \\
\text { of } 50 \% \text { for the TCS and } \\
\text { blend is below saturation } \\
\text { in major Na salts }\end{array}$ & $\begin{array}{l}\text { Perform lab test: to confirm that the as } \\
\text { retrieved waste remain below saturation in } \\
\text { major Na salts during the transfer to the } \\
\text { staging tanks }\end{array}$ & $\begin{array}{l}\text { None, sample } \\
\text { from Item } 1 \text { can } \\
\text { be used. }\end{array}$ \\
\hline 3 & $\begin{array}{l}\text { Determine viscosity, } \\
\text { SpG, suspended solids }\end{array}$ & $\begin{array}{l}\text { Perform lab test to determine viscosity, } \\
\text { SpG, suspended solids }\end{array}$ & $\begin{array}{l}300 \mathrm{ml} \\
241-\mathrm{SY}-103 \\
\text { WTC. }\end{array}$ \\
\hline 4 & $\begin{array}{l}\text { Determine solid } \\
\text { formation, if any }\end{array}$ & $\begin{array}{l}\text { An extended storage of supernate sub- } \\
\text { samples from the Tank Supernate } \\
\text { Composite (TSC) dilution test at dilution } \\
\text { ratio up to } 120 \% \text {. }\end{array}$ & $\begin{array}{l}\text { None, sample } \\
\text { from Item } 3 \text { can } \\
\text { be used. }\end{array}$ \\
\hline 5 & $\begin{array}{l}\text { Chemical and } \\
\text { radionuclide analyses. }\end{array}$ & $\begin{array}{l}\text { Measure the analytes in Section } 2.0 \text { (Tables } \\
1 \text { and 2) of main report (Envelope C } \\
\text { analytes). Determine the bulk supernate } \\
\text { composition. }\end{array}$ & $\begin{array}{l}\text { None, sample } \\
\text { from Item } 1 \text { can } \\
\text { be used. }\end{array}$ \\
\hline 6 & [Na] measurement & $\begin{array}{l}\text { Measurement of [Na] can be obtained from } \\
\text { Item } 5 \text {. }\end{array}$ & None. \\
\hline 7 & $\begin{array}{l}\text { Confirm insoluble solids } \\
\text { fraction limit will not } \\
\text { exceed } 5 \text { volume } \% \text {. }\end{array}$ & $\begin{array}{l}\text { Measurement of solid in the blend. This } \\
\text { data will be obtained during Item } 1 \text { testing. }\end{array}$ & None. \\
\hline 8 & $\begin{array}{l}\text { Operating Specification } \\
\text { requirements }\end{array}$ & $\begin{array}{l}\text { Perform lab test; Analysis of chemical and } \\
\text { radionuclides can be obtained by results } \\
\text { from Item } 5 \text {. }\end{array}$ & None \\
\hline
\end{tabular}


Table 4. Information Needs. (3 Sheets)

\begin{tabular}{|c|c|c|c|}
\hline Item & Information need & $\begin{array}{l}\text { Planned resolution } \\
\end{array}$ & Sample required \\
\hline 9 & $\begin{array}{l}\text { Determine sulfate } \\
\text { concentration as a } \\
\text { discriminator for } \\
\text { Envelope C. }\end{array}$ & $\begin{array}{l}\text { Perform lab test; Analysis of sulfate can be } \\
\text { obtained by results from Item } 5 \text {. }\end{array}$ & None \\
\hline 10 & $\begin{array}{l}\text { Determination of } \mathrm{Na} \\
\text { quantity }\end{array}$ & $\begin{array}{l}\text { Perform lab test; Analysis of Na can be } \\
\text { obtained by results from Item } 5 \text {. }\end{array}$ & None \\
\hline 11 & $\begin{array}{l}\text { Determine the Chemical } \\
\text { and radionuclide } \\
\text { analyses of heel in } \\
241-S Y-102 .\end{array}$ & $\begin{array}{l}\text { Perform lab test; Analysis of chemical and } \\
\text { radionuclides. }\end{array}$ & $\begin{array}{l}100 \mathrm{ml} \text { of } \\
241-\mathrm{SY}-102 \\
\text { heel. }\end{array}$ \\
\hline 12 & $\begin{array}{l}\text { Desired dilution ratio } \\
\text { and diluent composition } \\
\text { for a representative } \\
\text { sample of supernate and } \\
\text { salt slurry. }\end{array}$ & $\begin{array}{l}\text { Perform lab test: measure minimum dilution } \\
\text { ratio which satisfies all transfer system; } \\
\text { measure maximum dilution ratio where } \\
\text { gibbsite will not become a problem. } \\
\text { Determine desired dilution ratio and diluent. }\end{array}$ & $\begin{array}{l}300 \mathrm{ml} \\
241-\mathrm{SY}-103 \\
\text { Tank Supernate } \\
\text { Composite } \\
\text { (TSC). } 300 \mathrm{ml} \\
241-\mathrm{SY}-103 \text { tank } \\
\text { saltcake } \\
\text { composite } \\
\text { (TSCC) }\end{array}$ \\
\hline 13 & $\begin{array}{l}\text { Confirm as-retrieved } \\
\text { waste remains below } \\
\text { satn in major Na salts } \\
\text { during transfer. }\end{array}$ & $\begin{array}{l}\text { Perform lab test: to confirm that the as- } \\
\text { retrieved waste remains below saturation in } \\
\text { major Na salts during the transfer to the } \\
\text { staging tanks. Will be determined in Item } \\
12 \text {. }\end{array}$ & None. \\
\hline 14 & $\begin{array}{l}\text { Confirm as-retrieved } \\
\text { waste remains }<10 \mathrm{cP}, \\
<1.5 \mathrm{SpG} \text {, and }<30 \% \\
\text { solids during transfer. }\end{array}$ & $\begin{array}{l}\text { Perform lab test to determine viscosity, } \\
\text { SpG, suspended solids. Use sample from } \\
\text { Item } 12 \text {. }\end{array}$ & None. \\
\hline 15 & $\begin{array}{l}\text { Determine solid } \\
\text { formation and solid } \\
\text { settling time, if any. }\end{array}$ & $\begin{array}{l}\text { An extended storage of supernate sub- } \\
\text { samples from the TSC dilution test at } \\
\text { dilution ratio up to } 120 \% \text {. Use sample } \\
\text { from Item } 12\end{array}$ & None. \\
\hline 16 & $\begin{array}{l}\text { Chemical and } \\
\text { radionuclide analyses }\end{array}$ & $\begin{array}{l}\text { Measure the analytes in Section 2.0, Tables } \\
1 \text { and } 2 \text { (in main report) (Envelope C } \\
\text { analytes). Determine the bulk supernate } \\
\text { and diluted salt slurry composition from } \\
\text { Item } 12 \text {. }\end{array}$ & None. \\
\hline 17 & [Na] measurement & $\begin{array}{l}\text { Measurement of Na can be obtained from } \\
\text { Item } 16 .\end{array}$ & None \\
\hline
\end{tabular}


Table 4. Information Needs. (3 Sheets)

\begin{tabular}{|l|l|l|l|}
\hline Item & \multicolumn{1}{|c|}{ Information need } & \multicolumn{1}{|c|}{ Planned resolution } & Sample required \\
\hline 18 & $\begin{array}{l}\text { Operating Specification } \\
\text { requirements }\end{array}$ & $\begin{array}{l}\text { Perform lab test; Analysis of chemical and } \\
\text { radionuclides can be obtained by results } \\
\text { from Item 16. }\end{array}$ & None. \\
\hline 19 & $\begin{array}{l}\text { Determine percent solids } \\
\text { at various dilutions and } \\
\text { temperatures as a } \\
\text { function of time while } \\
\text { mixing. }\end{array}$ & $\begin{array}{l}\text { Perform lab test on mixed diluted } \\
241-S Y-101 \text { and 241-SY-103 waste. }\end{array}$ & $\begin{array}{l}150 \text { ml diluted } \\
241-S Y-101 \\
\text { WTC and } \\
150 \text { ml diluted } \\
241-S Y-103 \\
\text { WTC. }\end{array}$ \\
\hline 20 & $\begin{array}{l}\text { Confirm compatibility } \\
\text { with 241-SY-101 }\end{array}$ & $\begin{array}{l}\text { Perform process test; Mix diluted } \\
\text { 241-SY-101 with 241-SY-103 WTC. } \\
\text { During the lab test in Item 19 confirm } \\
\text { compatibility. }\end{array}$ & None. \\
\hline 21 & Determine settling times. & $\begin{array}{l}\text { During the lab test in Item 19 confirm } \\
\text { compatibility. }\end{array}$ & None. \\
\hline 22 & $\begin{array}{l}\text { Determine the Chemical } \\
\text { and radionuclide } \\
\text { analyses of dilute } \\
\text { mixture of 241-SY-101 } \\
\text { and 241-SY-103. }\end{array}$ & $\begin{array}{l}\text { Measure the analytes in Section 2.0, Tables } \\
\text { 1 and 2 (in main report) (Envelope C } \\
\text { analytes). Determine the bulk supernate } \\
\text { and diluted salt slurry composition. Waste } \\
\text { from Item 19 should be used. }\end{array}$ & None. \\
\hline
\end{tabular}

There are 22 items that have been flagged in Tables 1,2, and 3 requiring further information. All items will be addressed by a specific process test with specific material from 241-SY-103. There are no other information needs requiring either an analysis of an existing 241-SY-103 sample or the collection of additional sample followed by analysis in order to confirm that tank 241-SY-103 is appropriate for Batch 11. 
HNF-2799

Revision 0

\subsection{REFERENCES}

Boston, H. L., 1997, Subcontract Number 80232764-9-K001, Design Basis for Retrieval Equipment in Tanks $A N-104$ and $A N-105$, Letter to A. M. Umek (Fluor Daniel Hanford, Incorporated), LMHC-9758071, Lockheed Martin Hanford Corporation, Richland, Washington.

Certa, P. J., and J. Jo, 1998, Data Quality Objectives for TWRS Privatization Phase: 1 confirm Tank $T$ is an Appropriate Feed Source for Low-Activity Waste Feed Batch X, HNF-1796, Rev. 1, Numatec Hanford Corporation, Richland, Washington.

DOE-RL, 1996, TWRS Privatization, Contract Numbers DE-RP06-96RL13308 and 13309, U.S. Department of Energy, Richland, Washington.

Garfield, J. S., 1997, Tank 241-AN-104 Dilution/Dissolution Test Requirements, internal memo to DL Herting, 8C451-97-004 (March 27), Numatec Hanford Corporation, Richland, Washington.

Hansen, D. R., S. G. Metcalf, J. G. Douglas, W. I. Winters, K. W. Johnson, J. D. Franklin, 1996, Tank Characterization Report for Double-Shell Tank 241-SY-103, WHC-SD-WM-ER-691, Rev. 1, Westinghouse Hanford Company, Richland, Washington.

Kirkbride, R. A., G. K. Allen, P. J. Certa, A. F. Manuel, R. M. Orme, L. W. Shelton, E. J. Slaathaug, R. S. Wittman, G. T. MacLean and D. L. Penwell, 1997, Tank Waste Remediation System Operation and Utilization Plan,HNF-SD-WM-SP-012, Rev. 0A, Vol. I and II, Numatec Hanford Corporation, Richland, Washington.

PHMC, 1996, Unclassified Operating Specification for the 241-AN, AP, AW, $A Y, A Z$, and $S Y$ Tank Farms, OSD-T-151-00007, Rev. H-18, Fluor Daniel Hanford, Richland, Washington.

PHMC, 1997, Interface Control Document Between DOE and the PHMC, Low-Activity Waste Feed, HNF-SP-1223 (ICD-19), Project Hanford Management Contractor, Richland, Washington. 


\section{DISTRIBUTION SHEET}

\begin{tabular}{l|l|l}
\hline To & From & Page l of I \\
\cline { 3 - 3 } Distribution & J. Jo & Date 9/1/98 \\
\hline Project Title/Work Order & EDT No. 624562 \\
\cline { 3 - 3 } & & ECN No.
\end{tabular}

Application of "Confirm Tank $T$ is an Appropriate Feed Source for ECN No. Low-Activity Waste Feed Batch $X "$ to Specific Feed Batches, HNF-2799, Rev. 0

\begin{tabular}{|c|c|c|c|c|c|}
\hline Name & MSIN & $\begin{array}{l}\text { Text } \\
\text { With All } \\
\text { Attach. }\end{array}$ & Text Only & $\begin{array}{l}\text { Attach./ } \\
\text { Appendix } \\
\text { Only }\end{array}$ & $\begin{array}{c}\text { EDT/ECN } \\
\text { Only }\end{array}$ \\
\hline $\begin{array}{l}\text { Central Files } \\
\text { DOE Reading Room } \\
\text { DIMC }\end{array}$ & $\begin{array}{l}\text { B1-07 } \\
\mathrm{H} 2-53 \\
\mathrm{R} 1-41\end{array}$ & $\begin{array}{l}x \\
x \\
x\end{array}$ & & & \\
\hline S. K. Baker & R3-73 & $x$ & & & \\
\hline J. H. Baldwin & R3-73 & $\hat{x}$ & & & \\
\hline D. L. Banning & $\mathrm{R} 2-12$ & $\hat{x}$ & & & \\
\hline S. M. Blacker & R3-73 & $\hat{x}$ & & & \\
\hline J. F. Bores & R2-89 & $\hat{x}$ & & & \\
\hline H. L. Boston & R2-53 & $\hat{x}$ & & & \\
\hline v. C. Boyles & $\mathrm{R} 2-11$ & $\hat{x}$ & & & \\
\hline N. R. Brown & $K 6-51$ & $\hat{x}$ & & & \\
\hline P. J. Certa & R3-73 & $\hat{x}$ & & & \\
\hline R. D. Claghorn & R3-73 & $\hat{x}$ & & & \\
\hline T. W. Crawford & R3-73 & $\ddot{x}$ & & & \\
\hline J. S. Garfield & R3-73 & $\ddot{x}$ & & & \\
\hline K. M. Hal & $\mathrm{R} 2-12$ & $\hat{x}$ & & & \\
\hline D. L. Herting & T6-07 & $x$ & & & \\
\hline L. K. Holton & $\mathrm{A} 0-2 \mathrm{I}$ & $\hat{x}$ & & & \\
\hline J. W. Hunt & R2-12 & $\hat{x}$ & & & \\
\hline J. Jo & R2-12 & $\hat{x}$ & & & \\
\hline N. W. Kirch & R2-11 & $\hat{x}$ & & & \\
\hline J. G. Kristofzski & R2-12 & $\hat{x}$ & & & \\
\hline M. J. Kupfer & R3-73 & $\hat{x}$ & & & \\
\hline C. E. Leach & R1-49 & $x$ & & & \\
\hline R. P. Marshall & R3-74 & $x$ & & & \\
\hline C. H. Mulkey & $R 1-51$ & $x$ & & & \\
\hline R. J. Murkowski & $54-45$ & $\hat{x}$ & & & \\
\hline J. L. Nelson & $\mathrm{R} 1-30$ & $x$ & & & \\
\hline M. J. O'Neill & R3-75 & $x$ & & & \\
\hline S. M. O'Toole & R2-89 & $\hat{x}$ & & & \\
\hline R. M. Orme & R3-73 & $\hat{x}$ & & & \\
\hline I. G. Papp & R3-73 & $\hat{x}$ & & & \\
\hline L. D. Pennington & $57-21$ & $\hat{x}$ & & & \\
\hline D. L. Penwel] & R3-73 & $\hat{x}$ & & & \\
\hline B. B. Peters & R3-73 & $\hat{x}$ & & & \\
\hline R. D. Potter & R3-73 & $x$ & & & \\
\hline R. W. Powel1 & R3-75 & $\ddot{x}$ & & & \\
\hline W. T. Thompson & $R 3-73$ & $\ddot{x}$ & & & \\
\hline R. L. Treat & $\mathrm{R} 3-75$ & $x$ & & & \\
\hline N. C. Welliver & $\mathrm{K} 6-50$ & $x$ & & & \\
\hline K. D. Wi emers & $\mathrm{A} 0-21$ & $\hat{x}$ & & & \\
\hline W. I. Winters & $T 6-50$ & $x$ & & & \\
\hline
\end{tabular}

